\title{
EVALUATION OF GROUND-WATER FLOW AND SOLUTE TRANSPORT IN THE LOMPOC AREA, SANTA BARBARA COUNTY, CALIFORNIA
}

By Daniel J. Bright, David B. Nash, and Peter Martin

U.S. GEOLOGICAL SURVEY

Water-Resources Investigations Report 97-4056

Prepared in cooperation with the

Santa Ynez River Water Conservation District

ำ 


\title{
U.S. DEPARTMENT OF THE INTERIOR
}

BRUCE BABBITT, Secretary

\author{
U.S. GEOLOGICAL SURVEY \\ GORDON P. EATON, Director
}

Any use of trade, product, or firm names in this publication is for descriptive purposes only and does not imply endorsement by the U.S. Government.

For sale by the

U.S. Geological Survey

Branch of Information Services

Box 25286

Denver Federal Center

Denver, CO 80225

For additional information write to:

District Chief

U.S. Geological Survey

Placer Hall, Suite 2012

$6000 \mathrm{~J}$ Street

Sacramento, CA 95819-6129 


\section{CONTENTS}

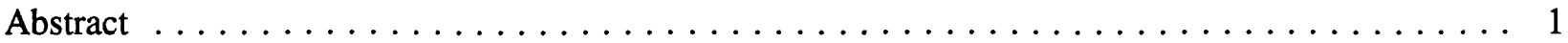

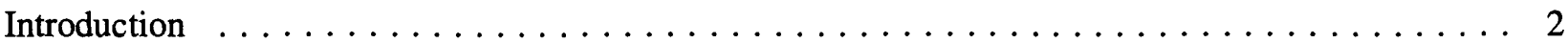

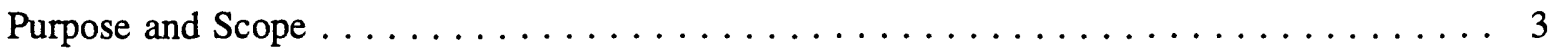

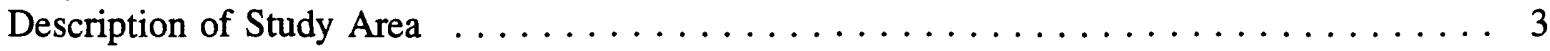

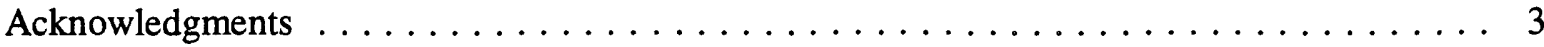

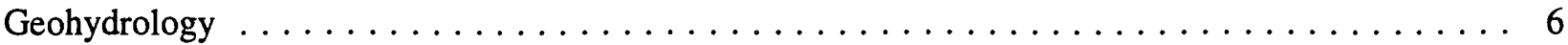

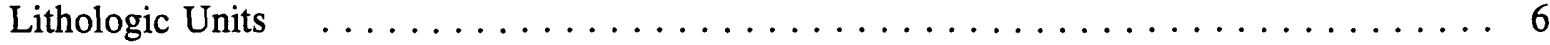

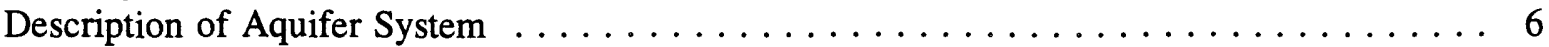

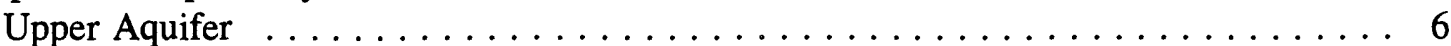

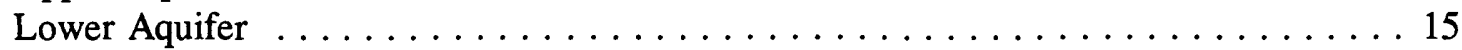

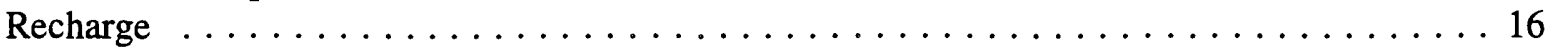

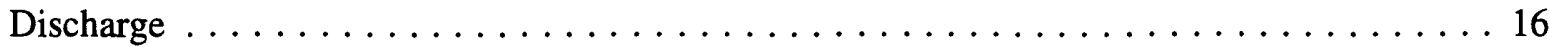

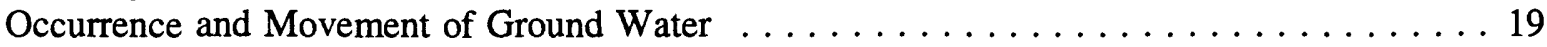

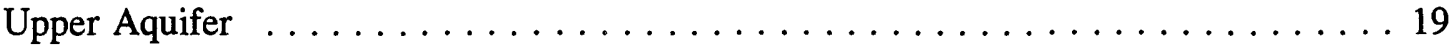

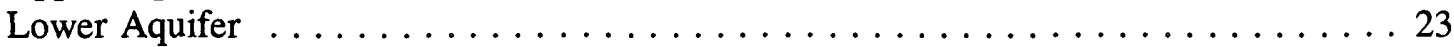

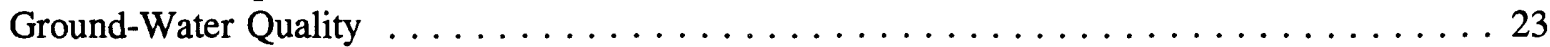

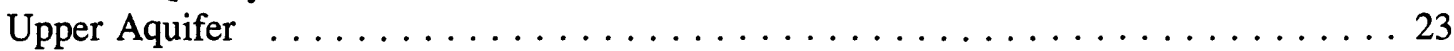

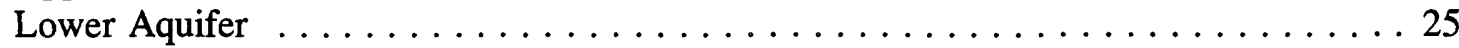

Numerical Simulation of Ground-Water Flow and Solute Transport . . . . . . . . . . . . 27

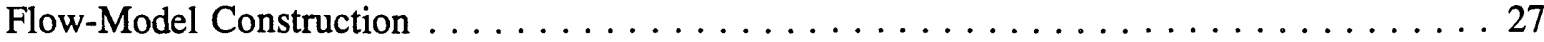

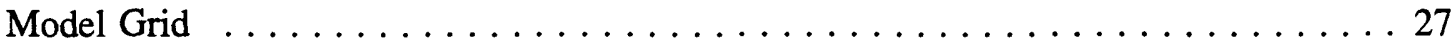

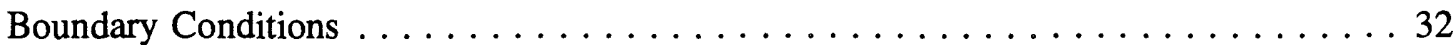

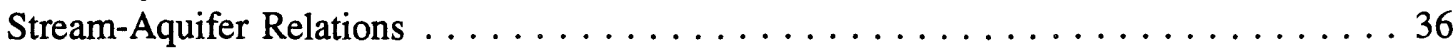

Simulated Recharge . . . . . . . . . . . . . . . . . . . . . . 38

Seepage Loss along the Southern Streams . . . . . . . . . . . . . 38

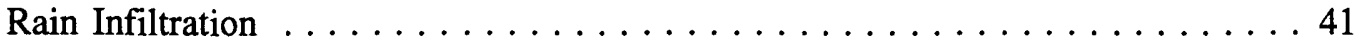

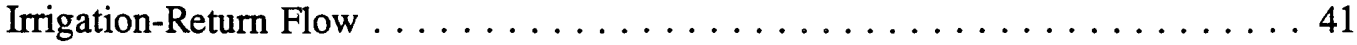

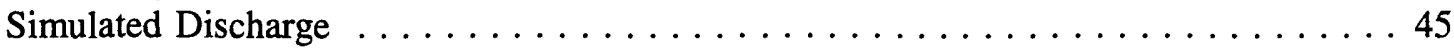

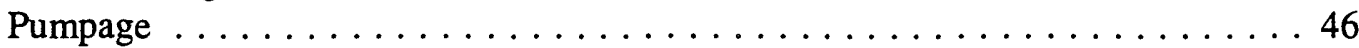

Drains ............................. 51

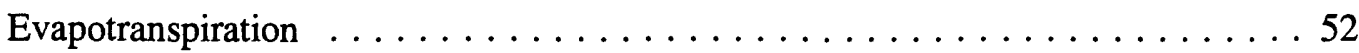

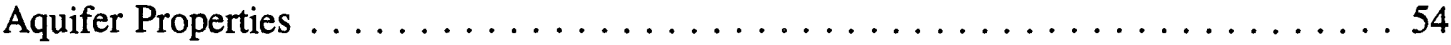

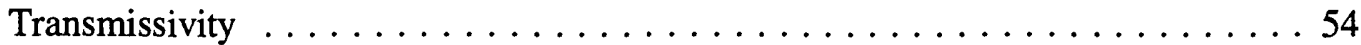

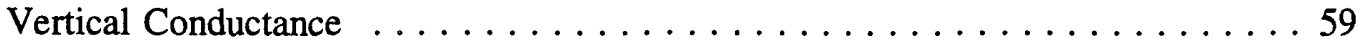

Storage Coefficient ........................... 63

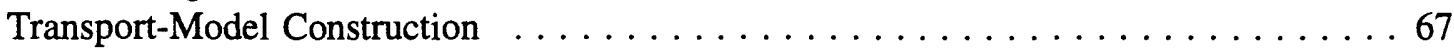

Model Grid ............................. 68

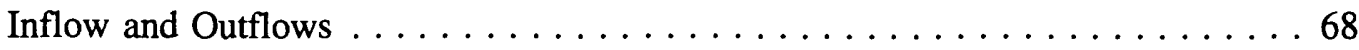

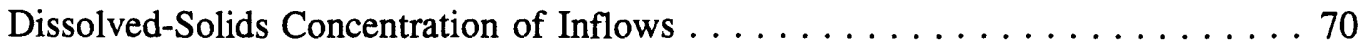

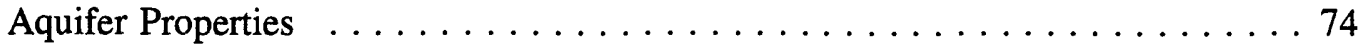

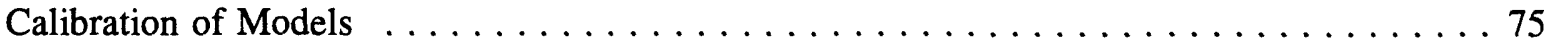

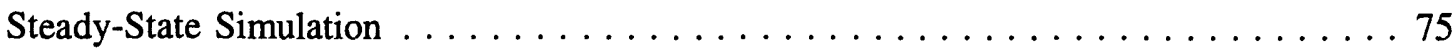

Transient Simulation . . . . . . . . . . . . . . . . . . . . . . . 79

Model Results . . . . . . . . . . . . . . . . . . . . . . . . 87

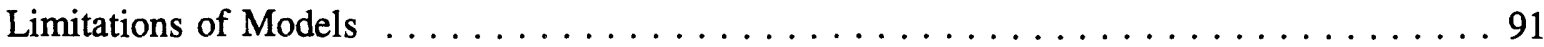


Simulated Effects of Proposed Management Alternatives on Water Levels and Water Quality . . . 93

Alternative $1:$ No Action $\ldots \ldots \ldots \ldots \ldots \ldots \ldots \ldots \ldots \ldots \ldots \ldots$

Alternative 2: Move Sewage-Effluent Discharge Point $\ldots \ldots \ldots \ldots \ldots \ldots \ldots$

Alternative 3: Increase Santa Ynez River Recharge . . . . . . . . . . . . . . . 100

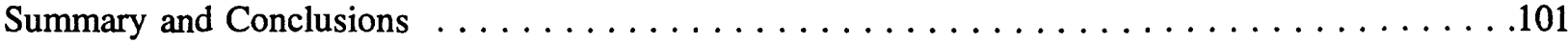

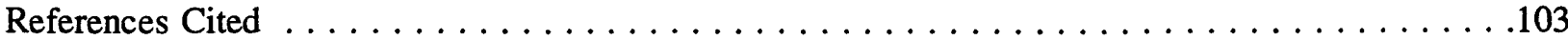

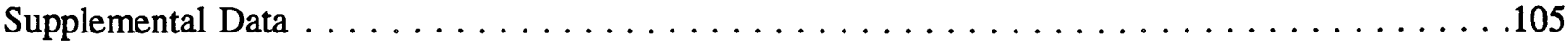

\section{FIGURES}

1.-3. Maps showing:

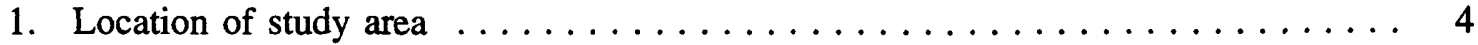

2. Subdivisions of the Lompoc plain and location of wells $\ldots \ldots \ldots \ldots \ldots$

3. Generalized geology of the Lompoc area $\ldots \ldots \ldots \ldots \ldots \ldots \ldots \ldots$

4. Generalized geologic sections $A-A^{\prime}$ and $B-B^{\prime}$ of the ground-water basin $\ldots \ldots \ldots$.

5. Map showing areal extent of upper and lower aquifers, and location of

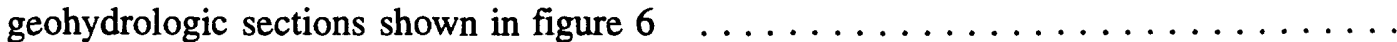

6. Generalized geohydrologic sections showing direction of ground-water movement and distribution of dissolved-solids concentration in the Lompoc area, 1987-88 . . . . 14

7. Graph showing components of annual pumpage in the Lompoc area, 1941-88 . . . . 18

8. Map showing potentiometric surfaces of the main zone of the upper aquifer,

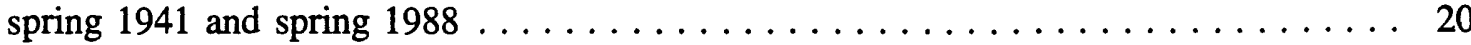

9. Graphs showing altitude of water levels for selected wells in the upper aquifer

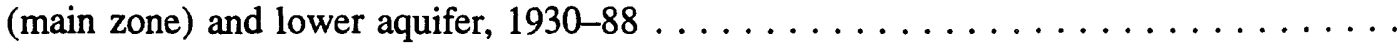

10. Graphs showing altitude of water levels for selected wells in the upper aquifer (shallow, middle, and main zones) and lower aquifer, 1987-88

11. Map showing potentiometric surfaces of the lower aquifer, summer 1987 and spring 1988

12. Graphs showing dissolved-solids concentration in samples from selected wells perforated in the main zone of the upper aquifer in the Lompoc area, 1924-88

13. Map showing model grid and boundary conditions for layers $1-4$ of the ground-water

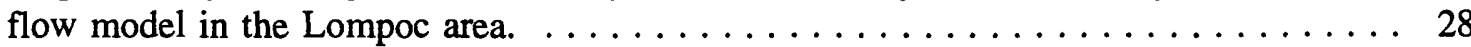

14. Diagram showing conceptualization of the ground-water flow system

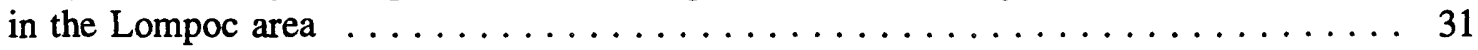

15. Graph showing seepage recharge from the southern streams, $1941-88 \ldots \ldots \ldots 2$

16.-25. Model grid of the Lompoc area showing areal distribution of:

16. Seepage from streams entering the southern plain $\ldots \ldots \ldots \ldots \ldots \ldots \ldots \ldots$

17. Recharge from rainfall infiltration $\ldots \ldots \ldots \ldots \ldots \ldots \ldots \ldots \ldots \ldots \ldots$

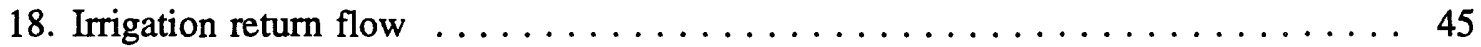

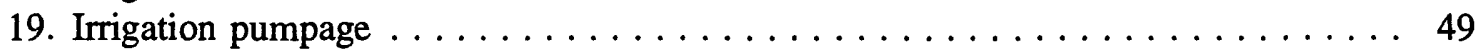

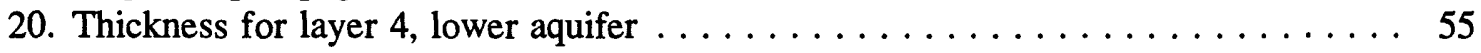

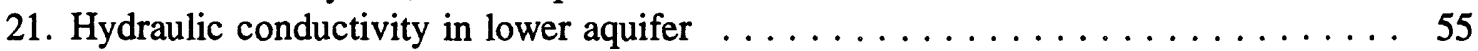

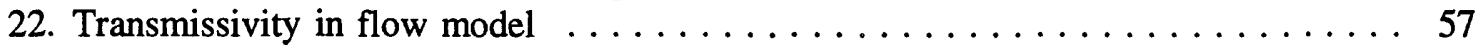

23. Horizontal to vertical anisotropy in flow model $\ldots \ldots \ldots \ldots \ldots \ldots \ldots \ldots$

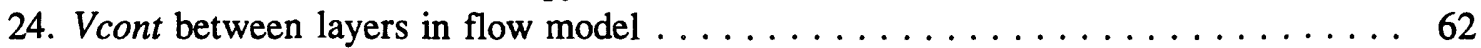

25. Storage coefficient in flow model $\ldots \ldots \ldots \ldots \ldots \ldots \ldots \ldots \ldots \ldots$

26. Diagrams showing solute-transport (SUTRA) model elements and nodes in the

Lompoc area: model grid of main zone and comparison with flow model cell 
27.-29. Model grid of the Lompoc area showing:

27. Areal distribution of dissolved-solids concentration for the solute-transport model . .

28. Measured hydraulic head, spring 1941, for the main zone of the upper aquifer and model-simulated hydraulic head, 1941 , for layer $3 \ldots \ldots \ldots \ldots$

29. Measured dissolved-solids concentrations, 1941, and model-simulated dissolved-solids concentration, 1941, for the main zone of the upper aquifer . . . . . .

30. Graphs showing measured and model-simulated discharge in the Santa Ynez River, 1941-88 ... . . . . . . . . . . . . . . . . . . . . . . . . . .

31. Graphs showing measured and model-simulated hydraulic heads at selected wells in the upper and lower aquifers in the Lompoc area, $1941-88 . \ldots \ldots \ldots \ldots \ldots \ldots$

32. Graphs showing average measured and model-simulated hydraulic heads at multiple-well sites in the eastern, central, and western plains in the Lompoc area,

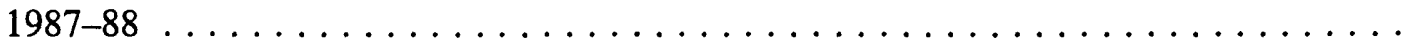

33. Map showing measured hydraulic head for the main zone of the upper aquifer and the lower aquifer, spring 1988, and model-simulated hydraulic head, 1988, for layer 3. . 85

34. Graphs showing measured and model-simulated dissolved-solids concentration at selected wells in the main zone of the upper aquifer in the Lompoc area, 1941-88 . . .

35. Map showing average measured dissolved-solids concentrations, March 1987-December 1988, and model-simulated dissolved-solids concentration, 1988 , for the main zone of the upper aquifer. . . . . . . . . . . .

36. Simulated change in hydraulic head in layer 3 for management alternatives 1,2 , and 3 in the Lompoc area, $1988-2013 . \ldots \ldots \ldots \ldots \ldots \ldots \ldots \ldots \ldots$

37. Simulated change in dissolved-solids concentration layer 3 in the Lompoc area for management alternatives 1,2 , and $3,1988-2013 . \ldots \ldots \ldots \ldots \ldots \ldots$

\section{TABLES}

1. Principal lithologic units and their water-bearing properties $\ldots \ldots \ldots \ldots \ldots \ldots$

2. Estimates of average annual recharge in the Lompoc area for selected periods . . . . . . 17

3. Estimates of average annual discharge in the Lompoc area for selected periods . . . . . . 18

4. Parameters for the general-head boundary package $\ldots \ldots \ldots \ldots \ldots \ldots \ldots \ldots$

5. Channel characteristics used in the streamflow-routing package $\ldots \ldots \ldots \ldots \ldots$

6. Discharge of the Santa Ynez River and the city of Lompoc sewage-treatment facility used in the streamflow-routing package $\ldots \ldots \ldots \ldots \ldots \ldots \ldots \ldots \ldots \ldots$

7. Characteristics of annual areal seepage from southern streams $\ldots \ldots \ldots \ldots \ldots \ldots$

8. Annual recharge from precipitation, irrigation return flow, and seepage from southern streams simulated in the ground-water flow model, $1941-88 \ldots \ldots \ldots \ldots \ldots \ldots$

9. Annual pumpage simulated in the ground-water flow model, $1941-88 \ldots \ldots \ldots \ldots$. . . 47

10. Results of mass-balance calculations of water contributed from the main zone of the upper aquifer and from the lower aquifer to production wells in the northern plain . . 51

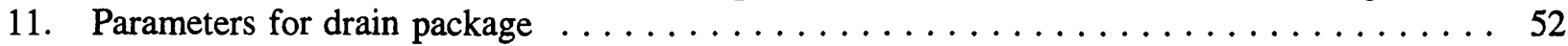

12. Parameters for evapotranspiration package $\ldots \ldots \ldots \ldots \ldots \ldots \ldots \ldots \ldots \ldots \ldots$

13. Estimated and model-calibrated transmissivity values $\ldots \ldots \ldots \ldots \ldots \ldots \ldots \ldots$

14. Estimated and model-calibrated storage-coefficient values $\ldots \ldots \ldots \ldots \ldots \ldots \ldots$

15. Steady-state and transient water budgets in the Lompoc area . . . . . . . . . . . . . . . 89

16. Simulated average streamflow and recharge along the Santa Ynez River for management alternatives 1, 2, and 3 in the Lompoc area, 1988-2013 


\section{CONVERSION FACTORS, ABBREVIATIONS, VERTICAL DATUM, AND WELL-NUMBERING SYSTEM}

\begin{tabular}{rcl}
\hline Multiply & By & To obtain \\
\hline acre-foot (acre-ft) & 1,233 & cubic meter \\
acre-foot (acre-ft) & 0.001233 & cubic hectometer \\
acre-foot per day (acre- $\mathrm{ft} / \mathrm{d})$ & 0.01427 & cubic meter per second \\
acre-foot per year (acre-ft/yr) & 1,233 & cubic meter per year \\
acre-foot per year (acre-ft/yr) & 0.001233 & cubic hectometer per year \\
cubic foot per second $\left(\mathrm{ft}^{3} / \mathrm{s}\right)$ & 0.02832 & cubic meter per second \\
foot $(\mathrm{ft})$ & 0.3048 & meter \\
foot per day $(\mathrm{ft} / \mathrm{d})$ & 0.3048 & meter per day \\
foot squared per day $\left(\mathrm{ft}^{2} / \mathrm{d}\right)$ & 0.0929 & meter squared per day \\
foot squared per pound $\left(\mathrm{ft}^{2} / \mathrm{lb}\right)$ & 0.02098 & square meter per newton \\
pounds per cubic foot $\left(\mathrm{lb} / \mathrm{ft}^{3}\right)$ & 157.1 & newton per cubic meter \\
inch $(\mathrm{in})$. & 25.4 & millimeter \\
inch per year $(\mathrm{in} / \mathrm{yr})$ & 25.4 & millimeter per year \\
mile $(\mathrm{mi})$ & 1.609 & kilometer \\
square foot $\left(\mathrm{ft}^{2}\right)$ & 0.09290 & square meter \\
square mile $\left(\mathrm{mi}{ }^{2}\right)$ & 259.0 & square kilometer \\
\hline
\end{tabular}

Temperature is given in degrees Celsius $\left({ }^{\circ} \mathrm{C}\right)$, which can be converted to degrees Fahrenheit $\left({ }^{\circ} \mathrm{F}\right)$ by the following equation:

$$
{ }^{\circ} \mathrm{F}=1.8\left({ }^{\circ} \mathrm{C}\right)+32 .
$$

Sea Level: In this report, "sea level" refers to the National Geodetic Vertical Datum of 1929 (NGVD of 1929) - a geodetic datum derived from a general adjustment of the first-order level nets of both the United States and Canada, formerly called Sea Level Datum of 1929. 


\section{Well-Numbering System}

Wells are identified and numbered according to their location in the rectangular system for subdivision of public lands. For example, in well number 007N035W33J002S, the identification number consists of the township number, north or south; the range number, east or west; and the section number. Each section is further divided into sixteen 40-acre tracts lettered consecutively (except $I$ and $O$ ), beginning with " $A$ " in the northeast corner of the section and progressing in a sinusoidal manner to " $R$ " in the southeast corner. Within each 40 -acre tract, wells are sequentially numbered in the order that they are inventoried. The final letter refers to the base line and meridian. In California, there are three base lines and meridians: Humboldt $(\mathrm{H})$, Mount Diablo (M), and San Bernardino (S). Because all wells in the study area are referenced to the San Bernardino base line and meridian, the final letter (S) will be omitted. In this report, well numbers are abbreviated and written $7 \mathrm{~N} / 35 \mathrm{~W}$ 33J2. Wells in the same township and range may be referred to by only their section designation, 33J2. The following diagram shows how the number for well $7 \mathrm{~N} / 35 \mathrm{~W}-33 \mathrm{~J} 2$ is derived.

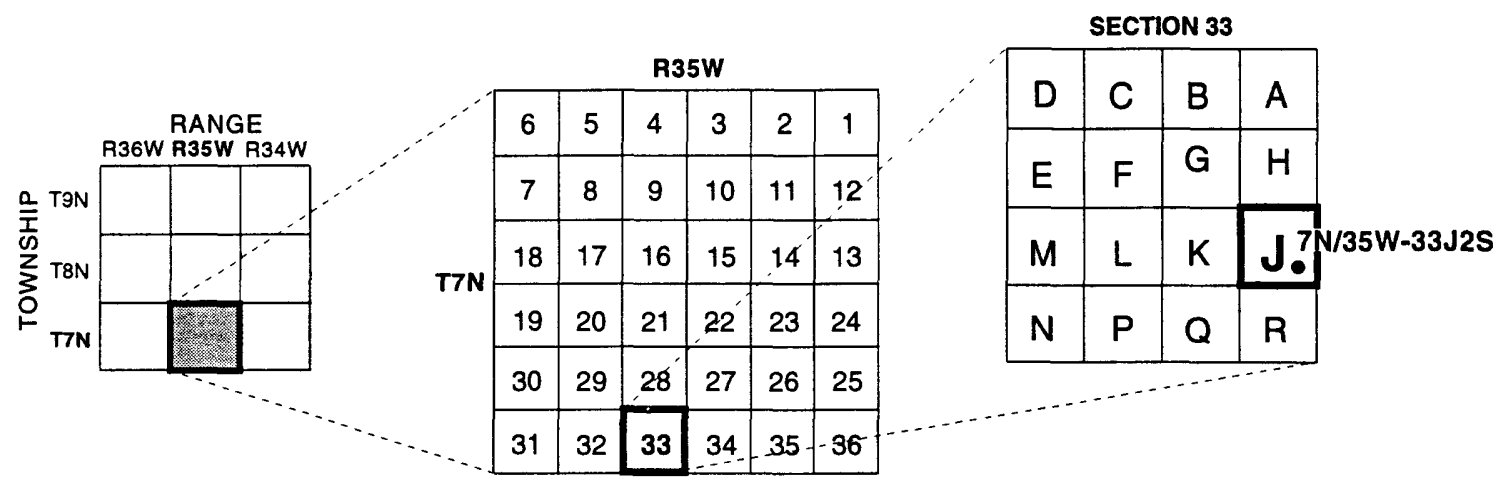

WELL-NUMBERING DIAGRAM 


\title{
EVALUATION OF GROUND-WATER FLOW AND SOLUTE TRANSPORT IN THE LOMPOC AREA, SANTA BARBARA COUNTY, CALIFORNIA
}

\author{
By Daniel J. Bright, David B. Nash, and Peter Martin
}

\begin{abstract}
Ground-water quality in the Lompoc area, especially in the Lompoc plain, is only marginally acceptable for most uses. Demand for ground water has increased for municipal use since the late 1950's and has continued to be high for irrigation on the Lompoc plain, the principal agricultural area in the Santa Ynez River basin. As use has increased, the quality of ground water has deteriorated in some areas of the Lompoc plain.
\end{abstract}

The dissolved-solids concentration in the main zone of the upper aquifer beneath most of the central and western plains has increased from less than 1,000 milligrams per liter in the 1940 's to greater than 2,000 milligrams per liter in the 1960's. Dissolved-solids concentration have remained relatively constant since the 1960's.

A three-dimensional finite-difference model was used to simulate ground-water flow in the Lompoc area and a two-dimensional finite-element model was used to simulate solute transport to gain a better understanding of the ground-water system and to evaluate the effects of proposed management plans for the ground-water basin. The aquifer system was simulated in the flow model as four horizontal layers. In the area of the Lompoc plain, the layers represent the shallow, middle, and main zones of the upper aquifer, and the lower aquifer. For the Lompoc upland and Lompoc terrace, the four layers represent the lower aquifer. The solute transport model was used to simulate dissolved-solids transport in the main zone of the upper aquifer beneath the Lompoc plain.

- The flow and solute-transport models were calibrated to transient conditions for 1941-88. A steady-state simulation was made to provide initial conditions for the transient-state simulation by using long-term average (1941-88) recharge rates. Model-simulated hydraulic heads generally were within 5 feet of measured heads in the main zone for transient conditions. Model-simulated dissolved-solids concentrations for the main zone generally differed less than 200 milligrams per liter from concentrations in 1988. 
During 1941-88 about 1,096,000 acre-feet of water was pumped from the aquifer system. Average pumpage for this period $(22,830$ acre-feet per year) exceeded pumpage for the steady-state simulation by 16,590 acre-feet per year. The results of the transient simulation indicate that about 60 percent of this increase in pumpage was contributed by increased recharge, 28 percent by decreased natural discharge from the system (primarily discharge to the Santa Ynez River and transpiration), and 13 percent was withdrawn from storage.

Total simulated downward leakage from the middle zone to the main zone in the central plain and upward leakage from the consolidated rocks to the main zone significantly increased in response to increased pumpage, which increased from about 6,240 to 30,870 acre-feet per year from 1941 to 1988. Average dissolved-solid concentration in the middle zone in 1987-88 ranged from 2,000 to 3,000 milligrams per liter beneath the northeastern plain and the dissolved-solids concentration of two samples from the consolidated rocks beneath the western plain averaged 4,300 milligrams per liter. Because the dissolved-solids concentration for the middle zone and the consolidated rocks is higher than the simulated steady-state dissolved-solids concentration of the main zone, the increase in the leakage from these two sources resulted in increased dissolved-solids concentration in the main zone during the transient period. The model results indicate that the main source of increased dissolved-solids concentration in the northeastern and central plains was downward leakage from the middle zone; whereas, upward leakage from the consolidated rocks was the main source of the increased dissolved-solids concentrations in the northwestern and western plains.

The models were used to estimate changes in hydraulic head and in dissolved-solids concentration resulting from three proposed management alternatives: (1) average recharge and discharge conditions, (2) move the sewage-effluent discharge point on the Santa Ynez River upstream from its present location to near Robinson Bridge, and (3) increase the quantity of streamflow to the Santa Ynez River by 3,000 acre-feet during the summer dry periods. The results of the management alternatives indicate that increasing recharge along the Santa Ynez River will result in a rise in the hydraulic head throughout the main zone. The dissolved-solids concentration in the main zone is projected to decrease beneath large parts of the eastern, northeastern, northwestern, and western plains in all management alternatives.

\section{INTRODUCTION}

Ground water historically has been the main source of agricultural, municipal, and military water supply in the Lompoc area. As ground-water use in the Lompoc area has increased, the quality of ground water has deteriorated in several parts of the Lompoc plain. There is concern that continued deterioration of ground-water quality will cause the ground water to become unusable for most purposes, including irrigation, without some treatment. State and local regulatory agencies and water users have recognized the need to reverse the trend of ground-water-quality deterioration. It was recognized, also, that to gain a better understanding of the ground-water system and to evaluate the hydraulic effects of proposed management plans for the ground-water basin, ground-water flow and solute-transport models were needed for the Lompoc area. 


\section{Purpose and Scope}

In 1986 the Santa Ynez River Water Conservation District entered into a cooperative program with the U.S. Geological Survey to study ground-water quality in the Lompoc area. In the first phase of the program, Bright and others (1992) described the ground-water hydrology and water quality of the Lompoc area of the Santa Ynez River ground-water basin. The objectives of the second phase of the program, described in this report, were to (1) evaluate and quantify the hydrologic and water-quality information presented in the first phase of the study, and (2) demonstrate some general long-term effects on water levels and water quality likely to occur as a result of proposed ground-water management alternatives. The hydrologic analysis in the second phase included the development and calibration of a ground-water flow model and a solute-transport model. The finite-difference groundwater flow model was used to simulate hydraulic heads in the aquifer system beneath the Lompoc plain, upland, and terrace, and to provide vertical and lateral flow values for the solute-transport model. The finite-element solute-transport model was used to simulate dissolved-solids concentration in the main zone of the upper aquifer beneath the Lompoc plain. These models can provide useful techniques for evaluating the potential effectiveness of ground-water management plans prior to their implementation.

\section{Description of Study Area}

The Lompoc area is in the western, coastal part of Santa Barbara County (fig. 1) in the Lompoc hydrologic subunit of the Santa Ynez hydrologic unit (California Department of Water Resources, 1964). The study area includes all of the Lompoc plain and most of the Lompoc terrace and Lompoc upland (fig. 1). For this report, the Lompoc plain is subdivided (as was done by Bright and others, 1992) into nine areas (fig. 2) to aid in the description of hydrologic conditions. The Lompoc area is bordered on the north by the Purisima Hills, on the east by the Santa Rita Hills, on the south by the foothills of the Santa Ynez Mountains, and on the west by the Pacific Ocean.

The area is drained by the Santa Ynez River and its tributaries (fig. 2). Perennial flow in the river occurs only in the westernmost part of the Lompoc plain where it is maintained by ground-water discharge, sewage effluent, and irrigation runoff. Several small streams flow year round in canyons south of the Lompoc plain. Ephemeral streams drain the north side of the basin and the Lompoc terrace area.

The principal land use in the Lompoc area is agriculture. Historically, the uplands were used for dry farming or pastureland and the flatlands for irrigated farming. The main urban areas are the city of Lompoc in the eastern part of the Lompoc plain and the communities of Vandenberg Village and Mission Hills in the Lompoc upland. The western quarter of the area is occupied by Vandenberg Air Force Base (VAFB).

\section{Acknowledgments}

Individuals in each of the following agencies provided hydrologic data for this investigation and are gratefully acknowledged: Gary Keefe, Virgil Godsey, Richard Wise, and Dale Ducharme of the city of Lompoc; Jon Ahlroth of the Santa Barbara County Water Agency; Christopher Reeves of the U.S. Bureau of Reclamation; Tom Hom, Richard Nichols, Donald Griggs, and Bert Johnson of Vandenberg Air Force Base; David Aguayo of the Federal Correctional Institution; Bill Morris and John Stratford of Vandenberg Village Community Services District; John Lewis and Kathy Schlottmann of Mission Hills Community Services District; Virginia Wilkinson of the Santa Ynez River Water Conservation District; and Thomas Stetson of Stetson Engineers, Inc. The cooperation extended by Steve Jordan of Jordan Brothers Ranch, and by Robert Witt and Jon Anderson of Robert Witt Ranch, in allowing access to data-collection sites on private land is greatly appreciated. 

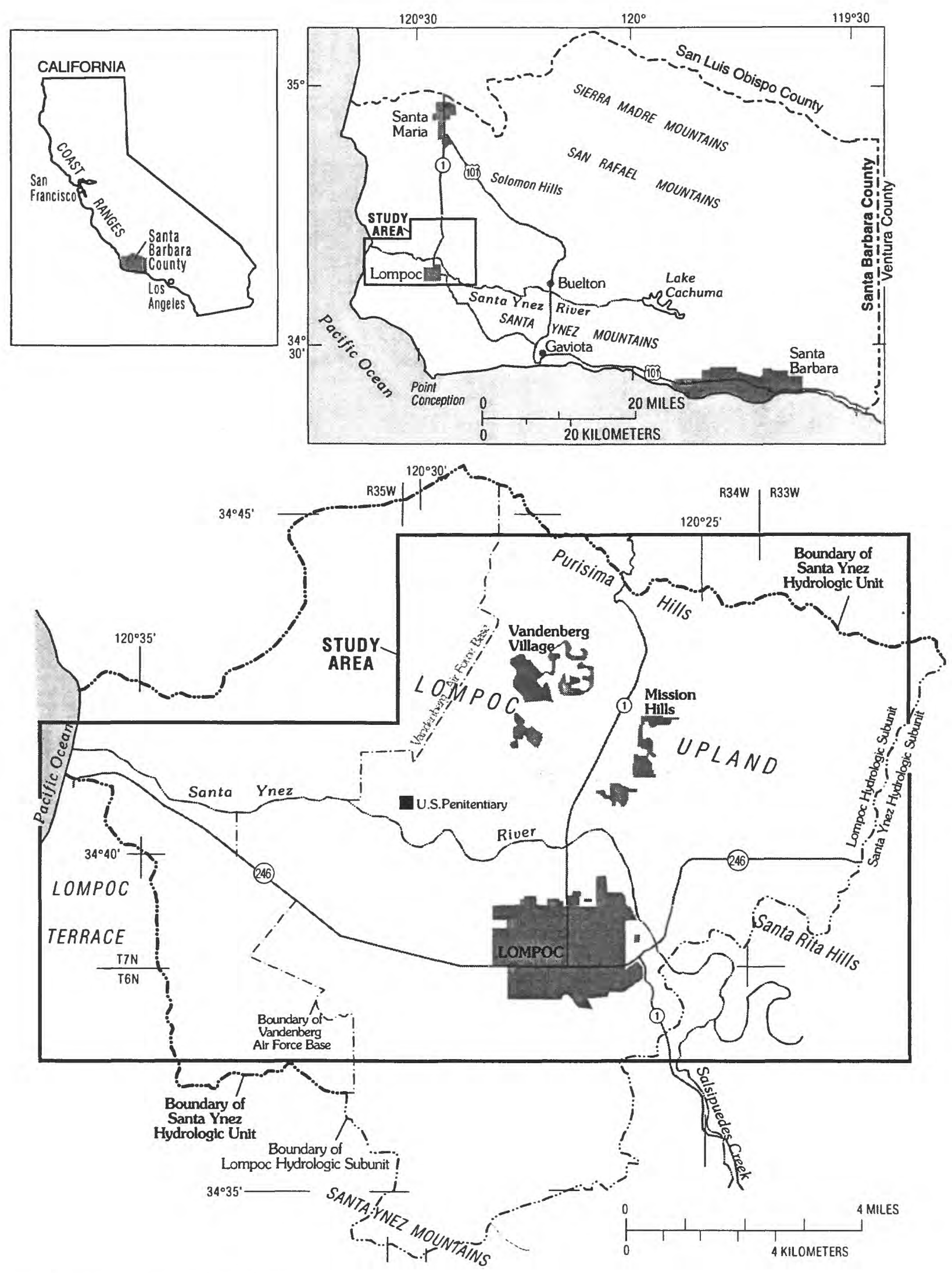

Figure 1. Location of the study area. 


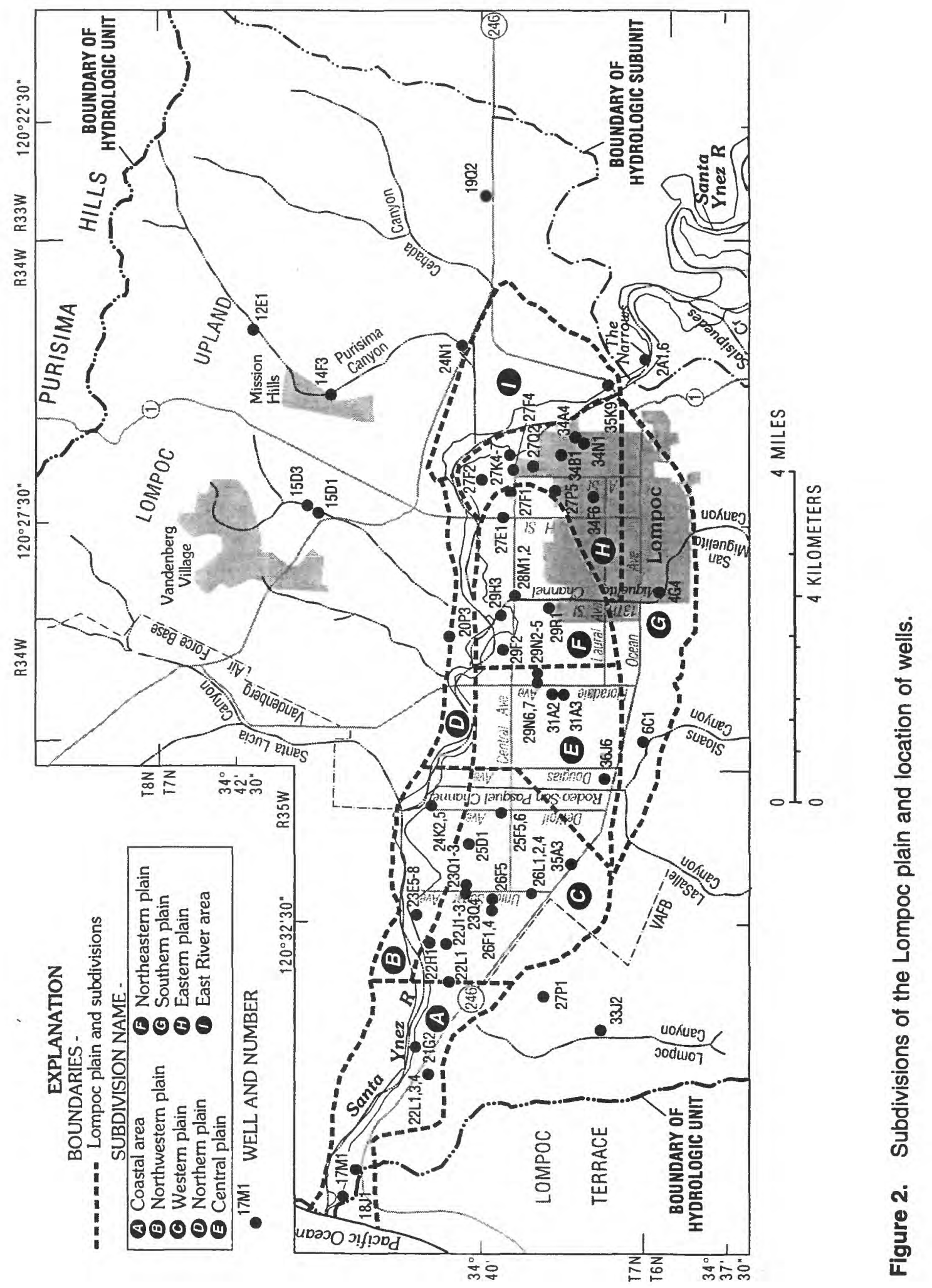




\section{GEOHYDROLOGY}

The geohydrology of the Lompoc area is discussed in detail by Upson and Thomasson (1951), Miller (1976), and Bright and others (1992). The geohydrologic analysis presented by Bright and others is summarized here for the purpose of providing the necessary background information for the reader to understand the construction of the numerical models discussed in the following sections. For a more complete description of the geohydrology of the Lompoc area, the reader is referred to these reports.

\section{Lithologic Units}

Lithologic units in the Lompoc area are divided into two general categories: (1) consolidated rocks, which underlie the ground-water basin and crop out in the surrounding hills; and (2) unconsolidated deposits, which compose the aquifers in the ground-water basin. The outcrop pattern of these units and their stratigraphic and structural relations are shown in figures 3 and 4.

The consolidated rocks include the Foxen, Sisquoc, and Monterey Formations (table 1). With the exception of fractured zones, the consolidated rocks are relatively impermeable and are not an important source of ground water. These rocks form the lower and much of the perimeter boundaries of the ground-water basin.

The unconsolidated deposits have been divided by previous investigators into eight subcategories (table 1). In upward succession, the unconsolidated lithologic units include the Cebada and Graciosa Members of the Careaga Sand of Pliocene age; the Paso Robles Formation of Pliocene to Pleistocene age; the Orcutt Sand of Pleistocene age; the terrace deposits of Pleistocene age; the lower and upper members of the alluvium of Holocene age; and the river-channel deposits of Holocene age. The thickness of these unconsolidated deposits is as great as about $900 \mathrm{ft}$ in the Santa Rita syncline beneath the Lompoc plain and greater than $1,500 \mathrm{ft}$ in the trough created by a series of synclinal folds beneath the Lompoc upland (see geologic section $A-A^{\prime}$ in figure 4).

The Holocene alluvial deposits range in thickness from a feather edge to a maximum of about 200 $\mathrm{ft}$ in the Lompoc plain. These deposits were formed by erosion and redeposition of the Pliocene and Pleistocene formations, and they rest unconformably on those older deposits. The characteristics and properties-including lithology, hydraulic head, and water quality-of the Holocene alluvial deposits are different from those of the underlying Pliocene and Pleistocene formations. These differences are described in the following sections of this report.

\section{Description of Aquifer System}

The unconformity separating the Holocene deposits from the Pliocene and Pleistocene formations serves as a natural boundary for dividing the aquifer system into two principal aquifers: the upper aquifer and the lower aquifer (fig. 4). The Holocene deposits form the upper aquifer, and the Pliocene and Pleistocene formations form the lower aquifer.

\section{Upper Aquifer}

The upper aquifer consists of the river-channel deposits and the upper and lower members of the alluvium. This aquifer is limited approximately to the area of the Lompoc plain (fig. 5). On the basis of geologic and geophysical logs of selected wells, the upper aquifer is subdivided into three zones: the shallow, middle, and main zones (fig. 6). 

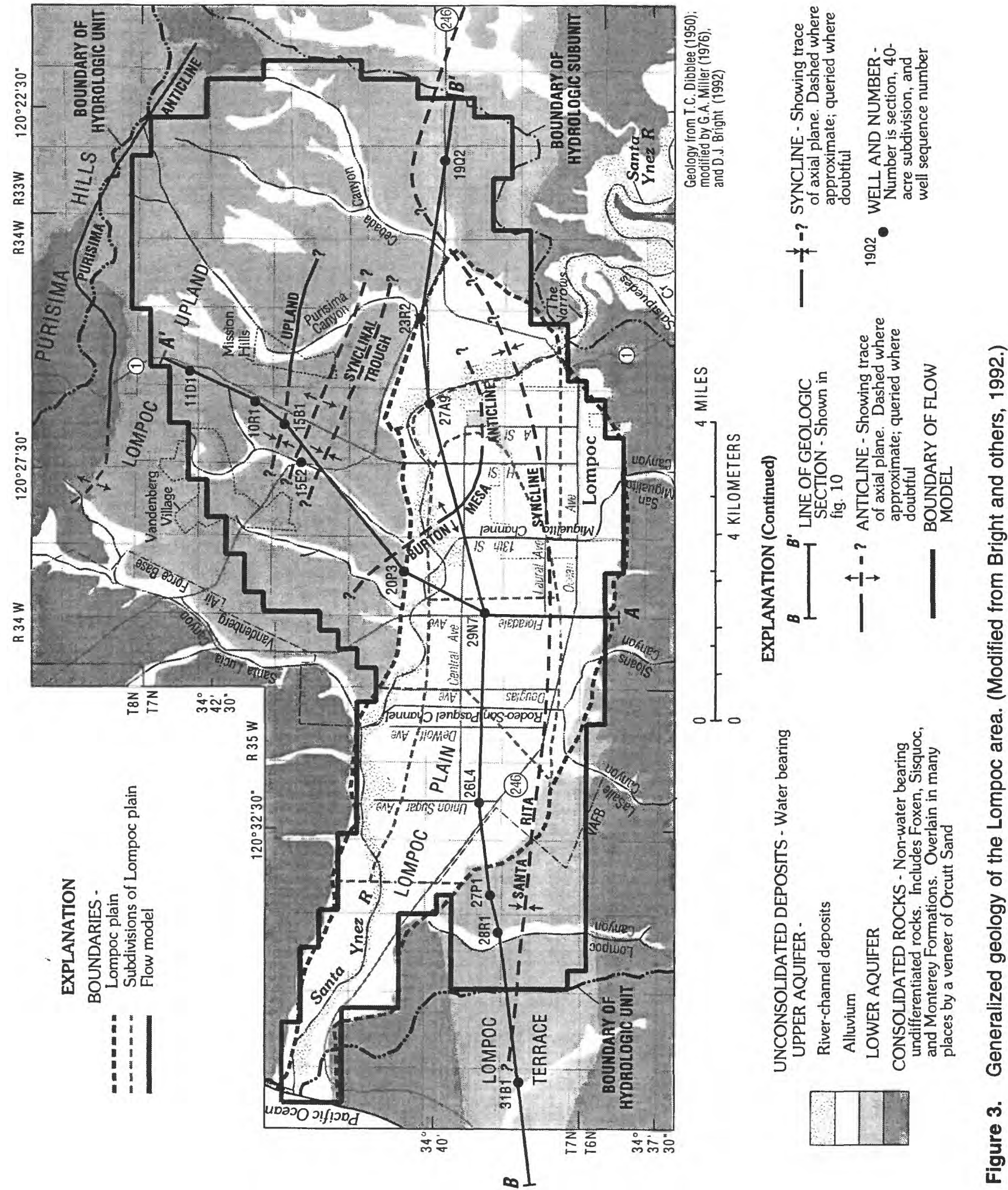

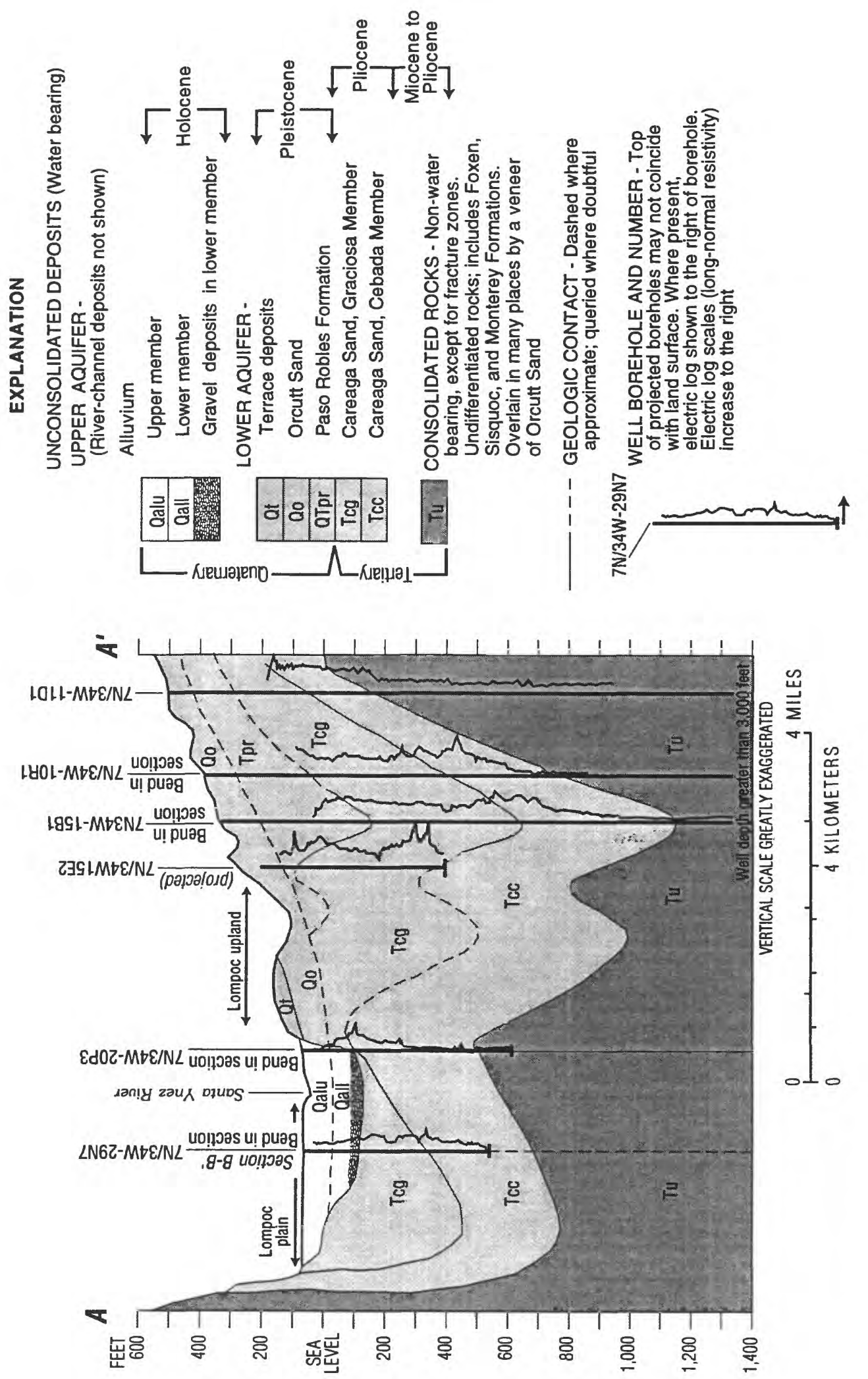

모드음

ธ

동

엄

ญ்

8

틍

$\stackrel{9}{ \pm}$

드

듬

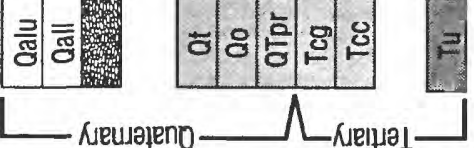

离

3

임

$\stackrel{Ð}{=}$

"5

ஸे กิ่

๓

든

广吉

$\checkmark$ 웅

ข

응 등

心

음

응은

응

융

츤

ले

రั)

0 몽

$+\subseteq$

은

흔오 


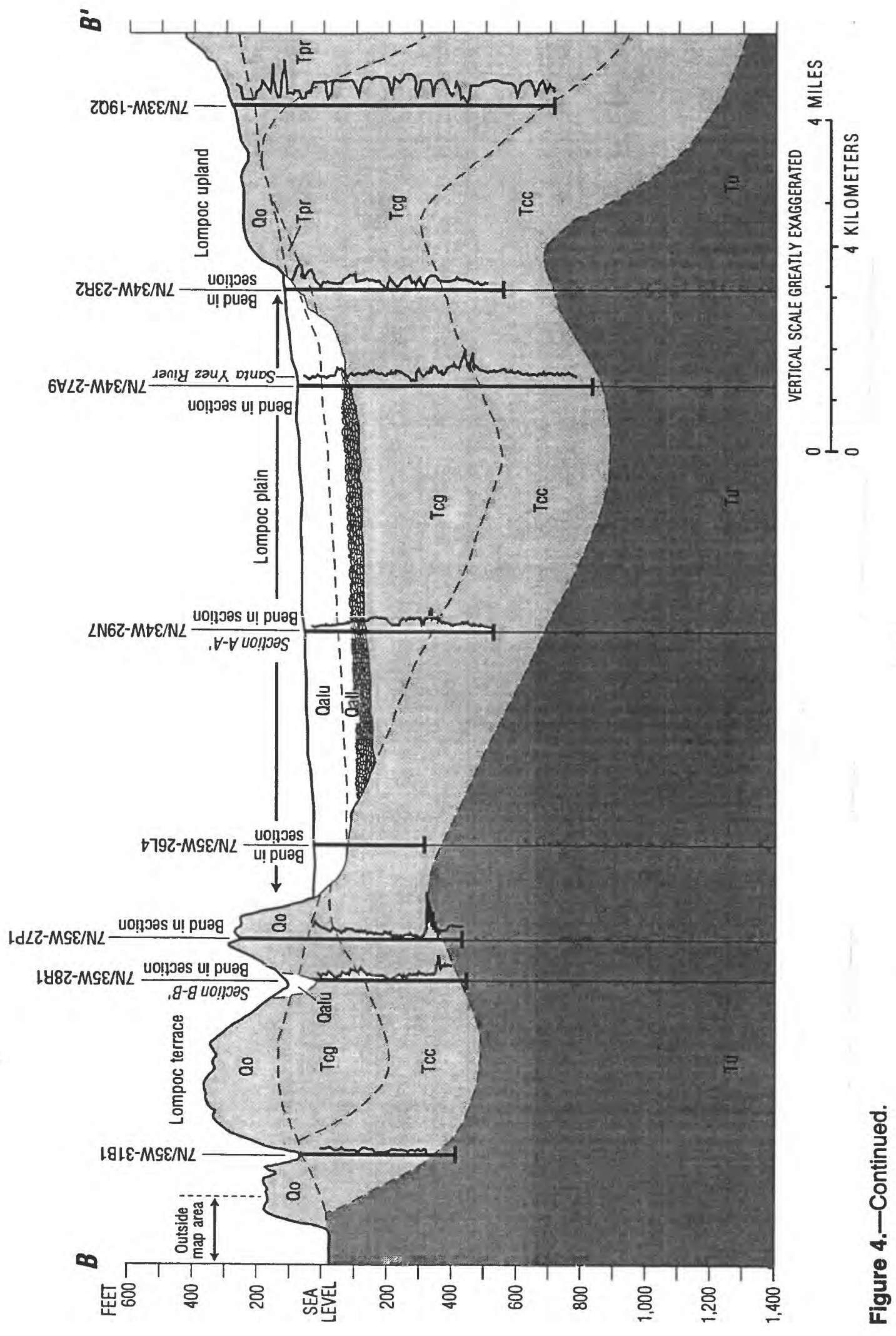




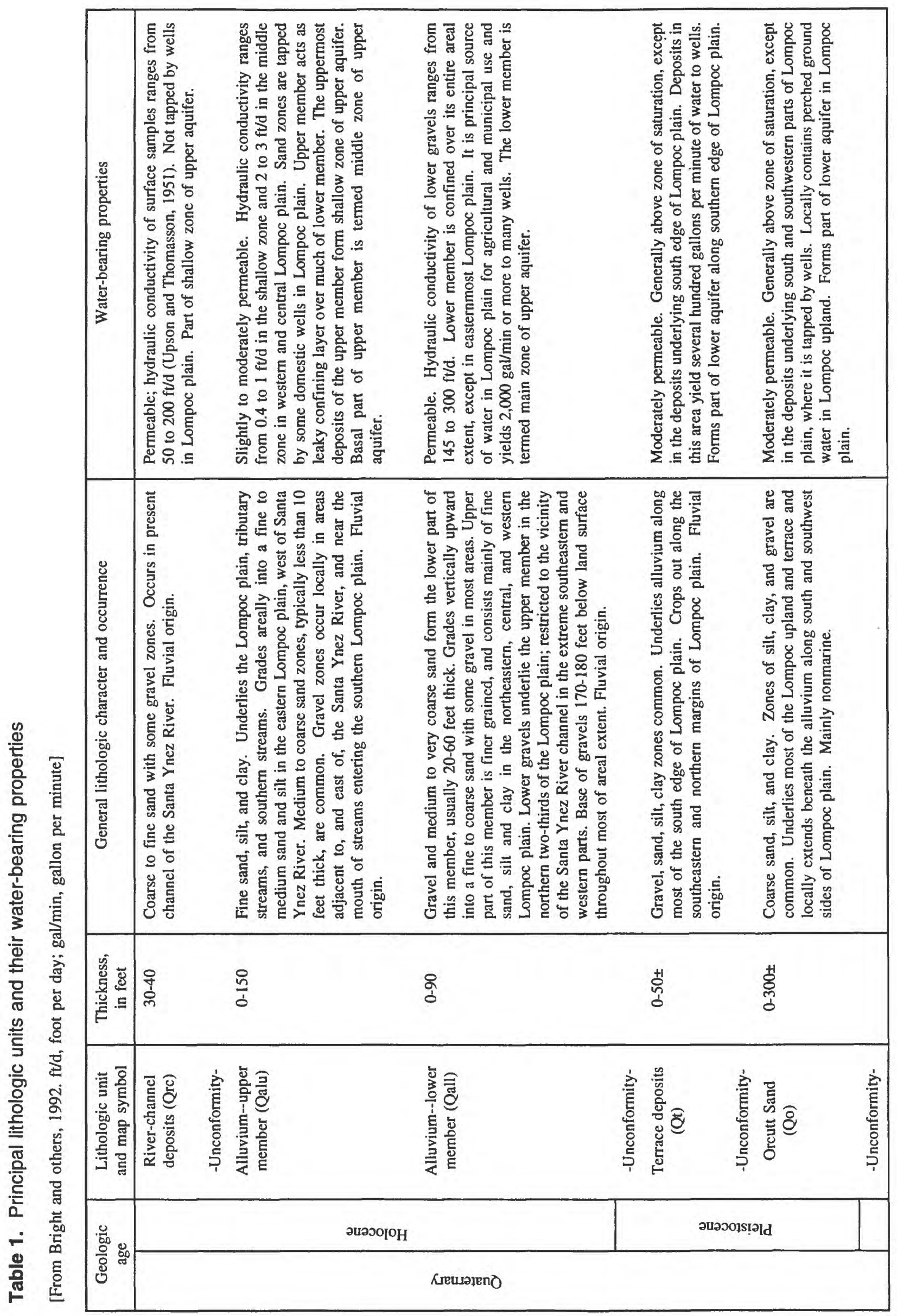




\begin{tabular}{|c|c|c|c|c|}
\hline 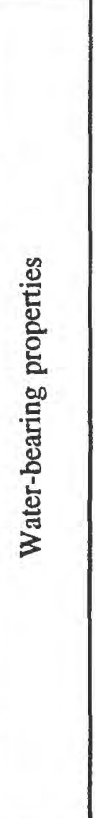 & 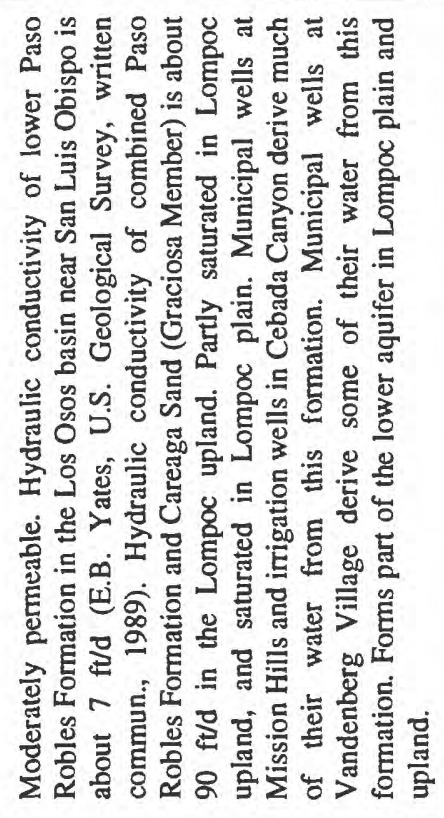 & 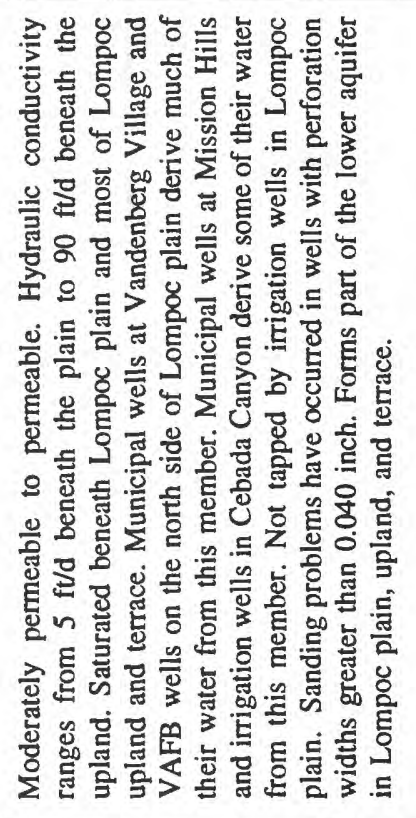 & 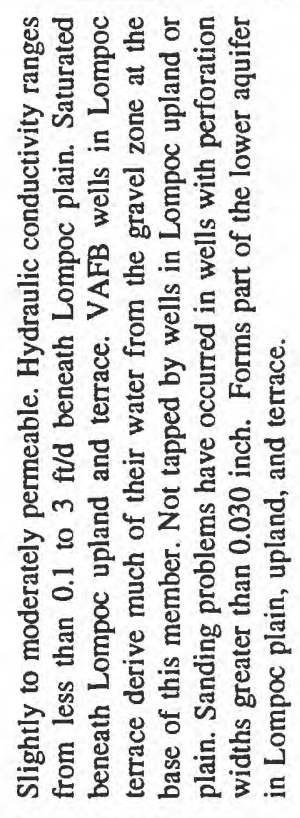 & 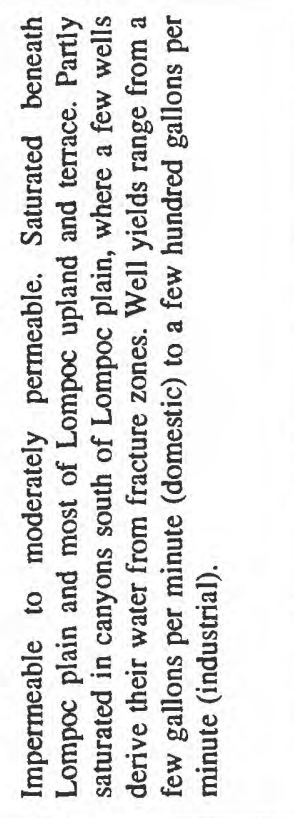 \\
\hline 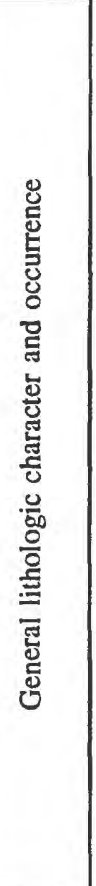 & 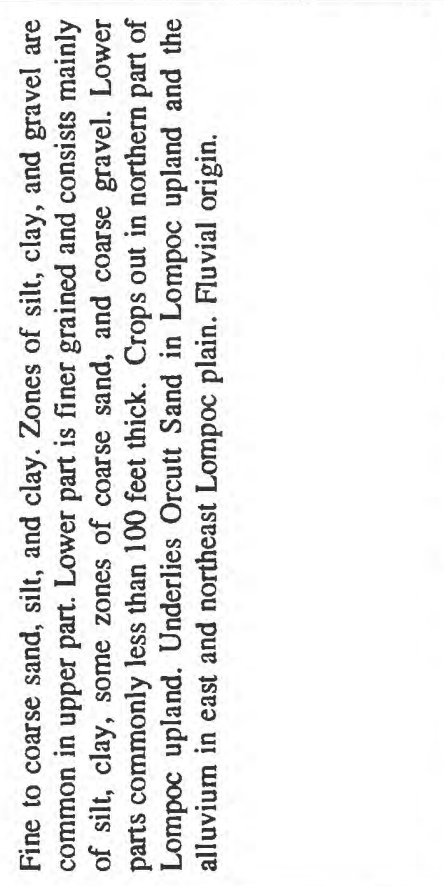 & 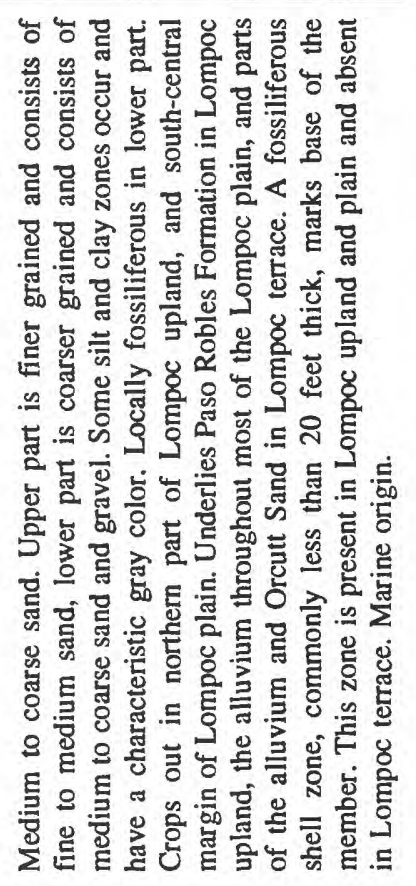 & 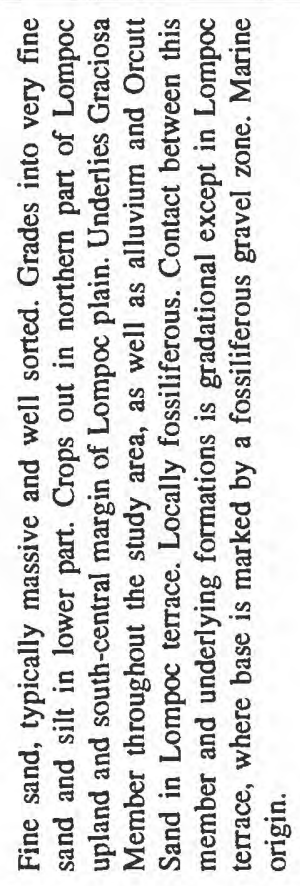 & 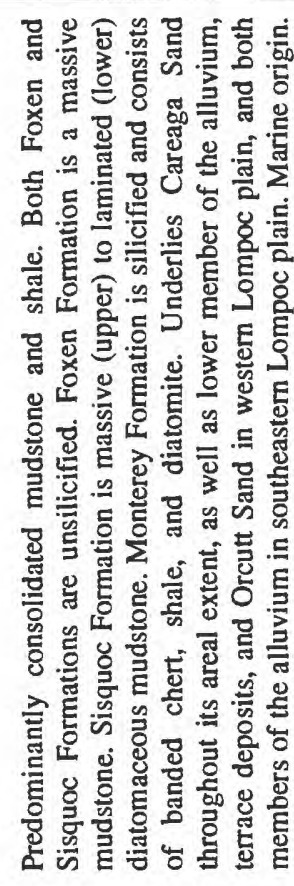 \\
\hline 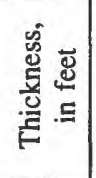 & $\begin{array}{l}\text { t! } \\
\text { ch } \\
0\end{array}$ & $\begin{array}{l}\text { ț } \\
\text { †े } \\
0\end{array}$ & 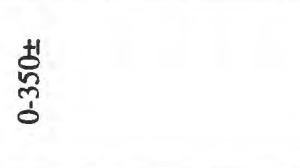 & 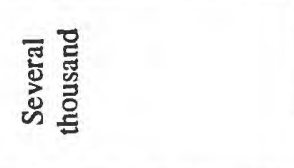 \\
\hline 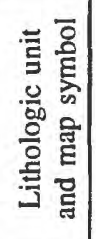 & 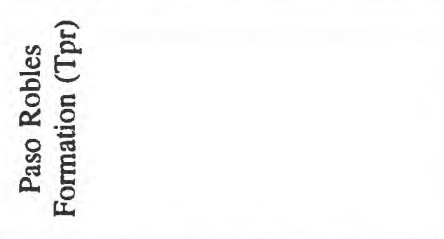 & 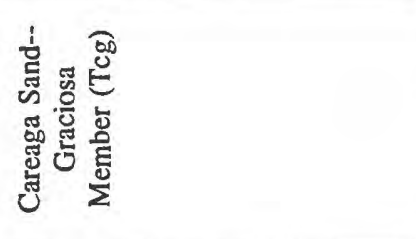 & 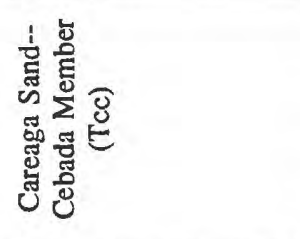 & 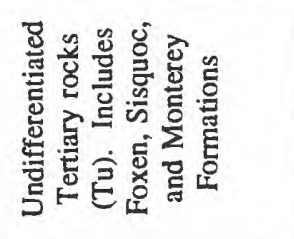 \\
\hline \multirow{2}{*}{$\begin{array}{l}\frac{0}{00} \\
\text { 응 } \\
0 \\
0\end{array}$} & 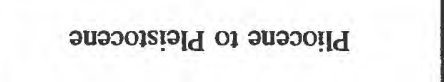 & วuəวั!ा & & วนววо!ाd 01 วuəวо!̣ \\
\hline & \multicolumn{4}{|c|}{ 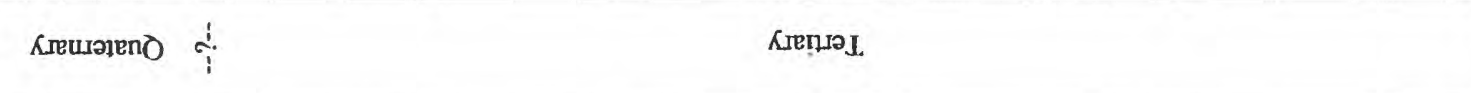 } \\
\hline
\end{tabular}



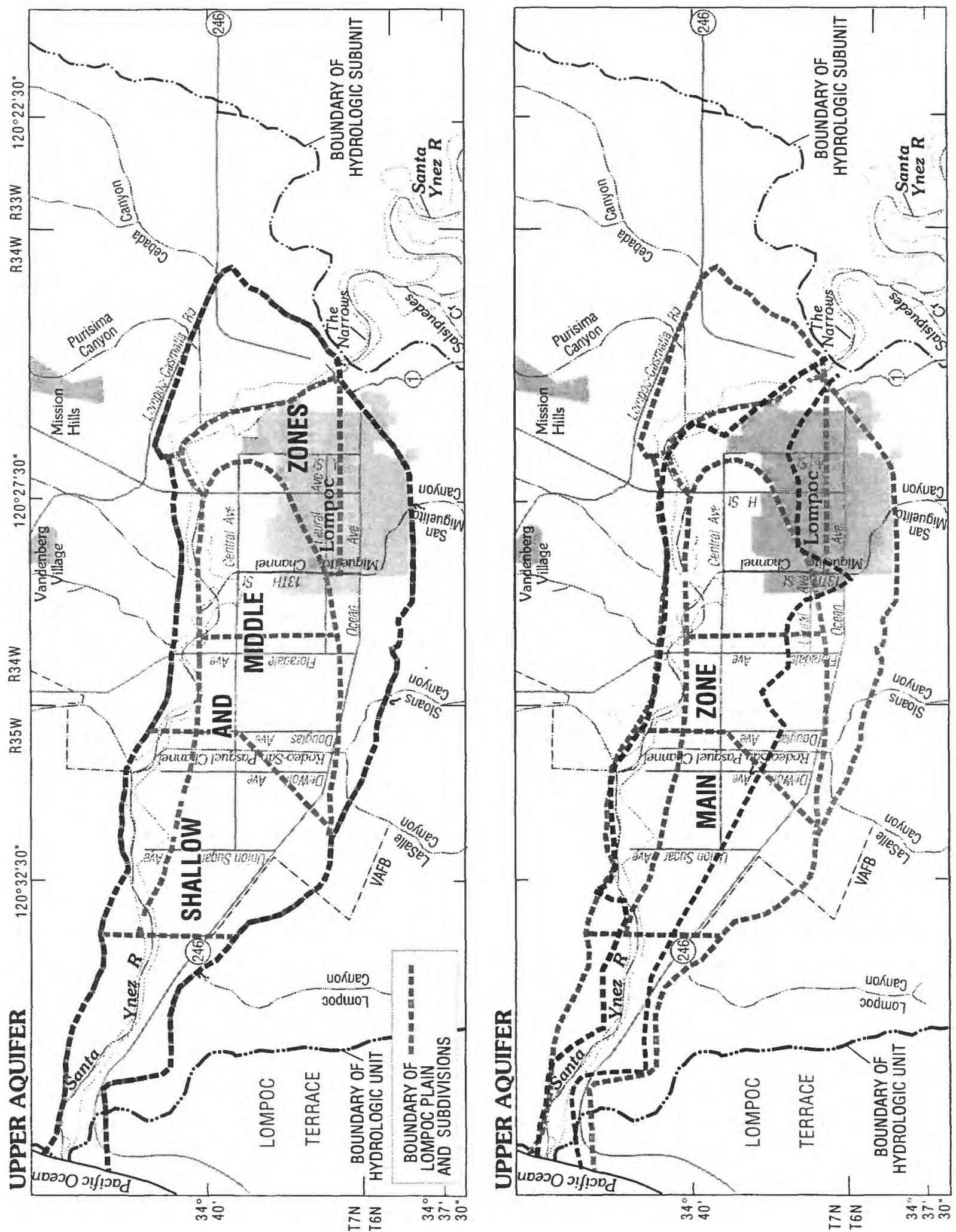

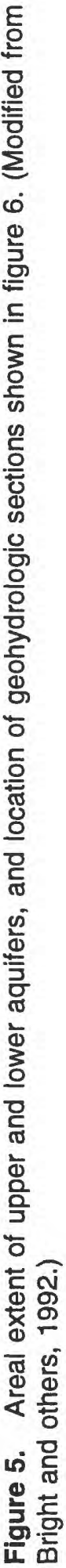



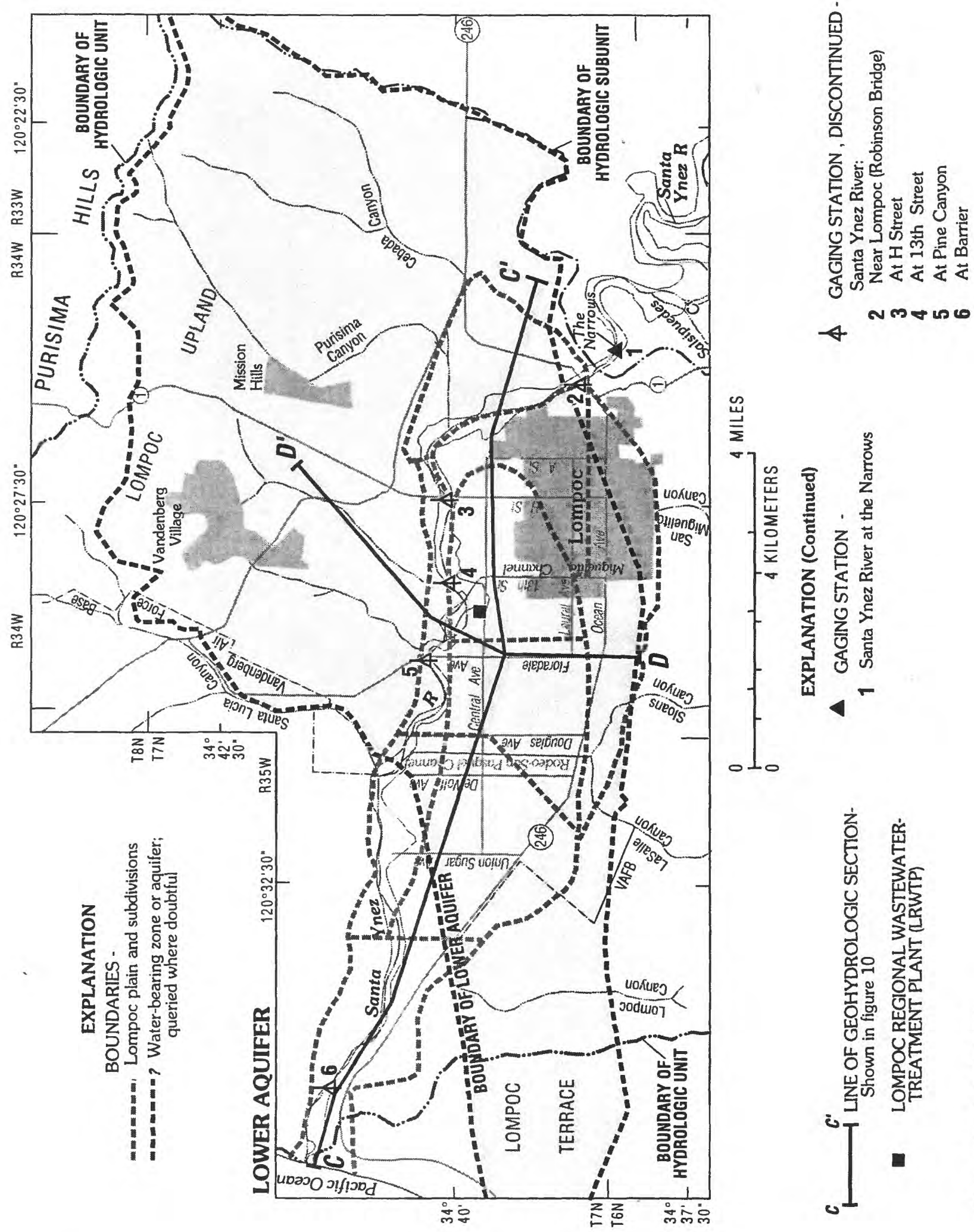

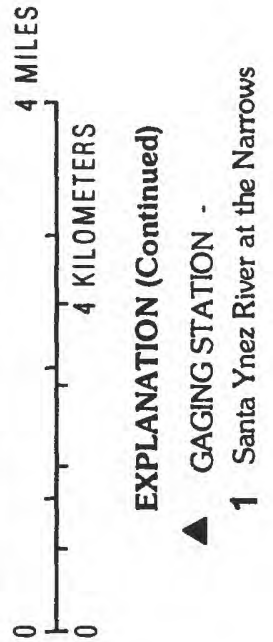

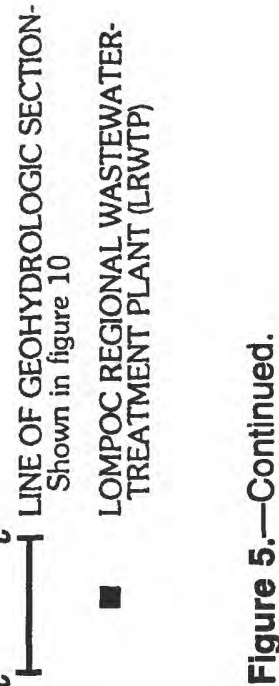




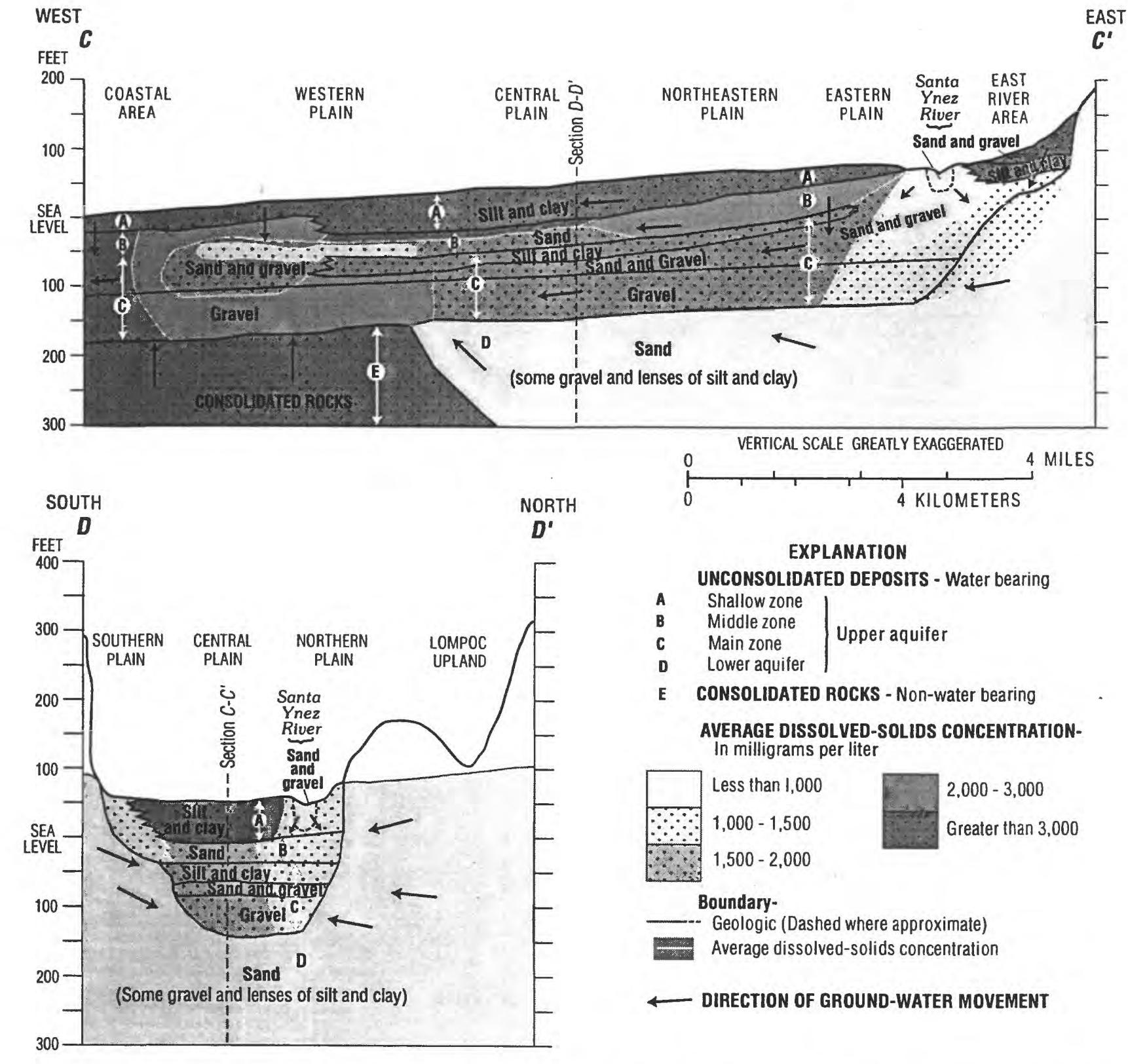

Figure 6. Generalized geohydrologic sections showing direction of ground-water movement and distribution of dissolved-solids concentration in the Lompoc area, 1987-88. Location of sections shown in figure 5. (Modified from Bright and others, 1992.)

The shallow zone of the upper aquifer is composed of the river-channel deposits and the shallow deposits of the upper member of the alluvium. The river-channel deposits are 30 to $40 \mathrm{ft}$ thick and consist of sand and gravel and are present beneath the channel of the Santa Ynez River. Hydraulic conductivity of the river-channel deposits ranges from 50 to $200 \mathrm{ft} / \mathrm{d}$ (table 1 ). The shallow alluvial deposits in the western, central, and northeastern plains consist primarily of low-permeability fine sand, silt, and clay layers that confine or partly confine the underlying deposits. Hydraulic conductivity of the deposits ranges from 0.4 to $1 \mathrm{ft} / \mathrm{d}$ (table 1). The thickness of the silt and clay deposits in the shallow zone generally increases from the northwestern plain to the western plain (Miller, 1976). These fine-grained deposits yield only small quantities of water to wells. Beneath the eastern, southern, and northwestern plains, the shallow alluvial deposits grade into fine to medium sand and contain occasional gravel or clay layers. In these areas, deposits in the upper aquifer underlying the shallow zone are generally unconfined. The average thickness of the shallow zone is $50 \mathrm{ft}$. 
The middle zone of the upper aquifer is composed of the lower part of the upper member of alluvium and contains moderately permeable sand and gravel lenses interbedded with fine sand, silt, and clay deposits. Hydraulic conductivity of sand lenses beneath the western and central plains ranges from 2 to $3 \mathrm{ft} / \mathrm{d}$ (table 1). The sand and gravel lenses which range from 5 to $40 \mathrm{ft}$ in thickness, yield small to moderate quantities of water to domestic wells in the Lompoc plain. Previous investigators considered these lenses to be part of the shallow zone (Upson and Thomasson, 1951, p. 12). However, the lenses beneath the western plain contained ground water of better quality (lower dissolved-solids concentration) than that in either the overlying shallow zone or underlying main zone in 1988, indicating that the lenses should be classified as a separate zone (Bright and others, 1992). In a manner similar to that in the shallow zone, the interbedded fine sand, silt, and clay deposits confine or partly confine the sand and gravel lenses in the western, central, and northeastern plains.

The main zone of the upper aquifer is composed of the lower member of the alluvium, which consists largely of medium to coarse sand and gravel. Hydraulic conductivity of the sand and gravel deposits ranges from 145 to $300 \mathrm{ft} / \mathrm{d}$ (table 1). These deposits yield large quantities of water to agricultural and municipal wells and are the main source of water supply in the Lompoc plain. The base of the sand and gravel deposits unconformably overlies the unconsolidated deposits that form the lower aquifer in the Lompoc plain.

Throughout most of the plain, the main zone of the upper aquifer is separated from the middle zone by lenses of silt and clay. These low-permeability lenses confine or partly confine the sand and gravel deposits in the main zone. In the eastern plain and northwestern plain, the silt and clay layers are less continuous or absent; as a result, ground water moves freely between zones in the upper aquifer. In the southern plain, the sand and gravel deposits in the main zone are absent, and the fine-grained deposits of the shallow and middle zones also are less continuous or absent (Upson and Thomasson, 1951, p. 146), permitting ground water to move freely between the shallow and middle zones of the upper aquifer and the lower aquifer.

\section{Lower Aquifer}

The lower aquifer, as defined in this report, consists of the terrace deposits, Orcutt Sand, Paso Robles Formation, and the Careaga Sand (fig. 4). Water-quality data collected in 1987-88 indicate that the Orcutt, Paso Robles, and Careaga units contain ground water of significantly better quality (lower dissolved-solids concentration) than that in the main zone. Also, hydraulic head in the terrace deposits in 1988 was more closely correlated with hydraulic head in the Careaga Sand than with head in the main zone. For these reasons, the terrace, Orcutt, Paso Robles, and Careaga units are considered a single aquifer.

The lower aquifer is present beneath the Lompoc upland, beneath the upper aquifer throughout the eastern two-thirds of the Lompoc plain, and beneath the Lompoc terrace (fig. 5). The lower aquifer is the primary aquifer in the Lompoc upland and Lompoc terrace. Beneath the Lompoc plain, the lower aquifer has not been used as a source of water, except by VAFB on the north side of the plain.

The terrace deposits and Orcutt Sand are highly permeable; however, they are unsaturated in most areas, except in the southern plain and southern part of the western plain. Beneath the upland and terrace, the Orcutt Sand locally contains perched ground water. Water levels in wells that tapped perched zones beneath the uplands in 1972 generally were more than $100 \mathrm{ft}$ higher than levels in the underlying Paso Robles Formation and Careaga Sand (Miller, 1976, p. 24). 
The Paso Robles Formation forms part of the lower aquifer beneath the Lompoc upland and beneath the east river area of the Lompoc plain. Much of this formation beneath the Lompoc upland is unsaturated. In the remaining parts of the study area, the formation is either completely unsaturated or not present.

The Graciosa and Cebada Members of the Careaga Sand are present beneath the Lompoc upland and most of the Lompoc plain. Beneath the Lompoc terrace, however, the Graciosa Member generally is absent or unsaturated. Where present, the Graciosa Member of the Careaga Sand is the main producer of ground water in the lower aquifer. Hydraulic conductivity of the Cebada Member ranges from 0.1 to $3 \mathrm{ft} / \mathrm{d}$ beneath the plain. Hydraulic conductivity of the Graciosa Member ranges from about $5 \mathrm{ft} / \mathrm{d}$ beneath the plain to $90 \mathrm{ft} / \mathrm{d}$ beneath the upland (table 1).

Ground water in the lower aquifer beneath the Lompoc plain is confined or partly confined by the stratified deposits that form this aquifer (Paso Robles Formation and Graciosa Member of the Careaga Sand) and by the overlying fine-grained deposits in the upper aquifer. Beneath the upland and terrace, however, these stratified deposits are partially unsaturated below the perched ground-water system in the Orcutt Sand. As a result, unconfined conditions probably exist in the shallow parts of the lower aquifer beneath the upland and terrace. Depth-dependent hydraulic-head data, however, are not available to determine the vertical and areal extent of the unconfined conditions in these areas.

\section{Recharge}

The primary sources of recharge to the Lompoc area include (1) seepage loss from the Santa Ynez River and from streams entering the southern plain and coastal area, (2) infiltration of rainfall, (3) infiltration of excess irrigation water, (4) underflow from river-channel deposits, and (5) infiltration of sewage effluent. Estimates of average annual recharge from earlier studies by Upson and Thomasson (1951), Wilson (1959), Evenson (1966), Miller (1976), and Ahlroth and others (1977) are summarized in table 2.

Previous estimates of average annual recharge to the Lompoc area for selected periods vary considerably because of differences in climatic conditions. Precipitation during 1957-62, 1972, and 1975-76 was close to the long-term average (1910-87) of 14.6 in/yr (U.S. Department of Agriculture, 1910-30; U.S. Department of Commerce, 1954-76; National Oceanic and Atmospheric Administration, 1976-88) and was considered to represent near-normal climatic conditions. Extremely wet conditions existed during 1935-44 when Upson and Thomasson studied the Lompoc area, and extremely dry conditions existed during 1947-51 when Wilson studied the area.

\section{Discharge}

The primary components of ground-water discharge from the aquifers in the Lompoc area include (1) agricultural, municipal, and military pumpage, (2) transpiration by phreatophytes along the Santa Ynez River, (3) underflow from the upper aquifer to the offshore deposits beneath the Pacific Ocean, and (4) seepage to the Santa Ynez River in the coastal area. Estimates of discharge from earlier studies are summarized in table 3.

The main component of ground-water discharge in the Lompoc area has been ground-water pumpage. Ground water has been used primarily for irrigation, municipal, and military purposes. The annual distribution of the various pumpages from the ground-water basin for 1941-88 is shown graphically in figure 7. For years in which pumpage data are lacking, estimates were made by interpolating between calculated values. Ground-water pumpage reached a maximum of 29,600 acre-ft in 1960 (estimates from electric-use records indicate that 1988 may have exceeded the 1960 total) and has remained relatively constant since that time, except for a slight decrease in the middle and late 1960's. 
Most of the ground-water pumpage in the Lompoc area historically has been used for irrigation. Irrigation wells are located throughout the Lompoc plain, with the exceptions of the areas occupied by the city of Lompoc and VAFB. Municipal and military pumpages increased significantly in the late 1950 's and early 1960's (fig. 7). Although municipal pumpage has remained relatively constant since the 1960's, military pumpage in the Lompoc area has decreased in recent years because VAFB now obtains a greater percentage of its supply from pumpage in the San Antonio Creek valley north of the Santa Ynez River drainage.

Estimates of transpiration by phreatophytes along the Santa Ynez River are given in table 3. Upson and Thomasson (1951) also included transpiration by phreatophytes in the western plain and evaporation from the Santa Ynez River and from bare areas in the channel. The transpiration estimate

Table 2. Estimates of average annual recharge in the Lompoc area for selected periods

[Recharge values are in acre-foot. in., inch; --, no data]

\begin{tabular}{|c|c|c|c|c|c|}
\hline $\begin{array}{l}\text { Recharge } \\
\text { source }\end{array}$ & $\begin{array}{l}1935-44 \\
\text { (Upson and } \\
\text { Thomasson, } \\
\text { 1951) }\end{array}$ & $\begin{array}{c}\text { 1947-51 } \\
\text { (Wilson, } \\
\text { 1959) }\end{array}$ & $\begin{array}{c}1957-62 \\
\text { (Evenson, } \\
1966 \text { ) }\end{array}$ & $\begin{array}{c}1972 \\
\text { (Miller, } \\
\text { 1976) }\end{array}$ & $\begin{array}{c}1975-76 \\
\text { (Ahlroth and } \\
\text { others } \\
1977)\end{array}$ \\
\hline \multicolumn{6}{|l|}{ Seepage loss } \\
\hline Narrows to LRWTP . & 2,200 & 500 & 4,600 & 3,000 & 4,000 \\
\hline $\begin{array}{l}\text { Douglas Ave. to } 0.5 \text { mile west } \\
\text { of Union Sugar Ave. } \ldots \ldots \ldots \ldots\end{array}$ & 300 & 800 & ${ }^{1} 3,700$ & ${ }^{2} 2,300$ & 2,000 \\
\hline $\begin{array}{l}\text { Streams entering the southern } \\
\text { plain and coastal area. }{ }^{3} \ldots\end{array}$ & 5,400 & 700 & 7,000 & 1,200 & 3,600 \\
\hline $\begin{array}{l}\text { Rainfall infiltration } \\
\quad \text { Lompoc plain } \ldots \ldots \ldots \ldots \ldots \ldots \ldots \\
\text { Lompoc upland } \ldots \ldots \ldots \ldots \ldots\end{array}$ & $\begin{array}{r}4,800 \\
4,600\end{array}$ & $\begin{array}{r}0 \\
900\end{array}$ & $\begin{array}{l}3,500 \\
2,600\end{array}$ & $\begin{array}{l}4,000 \\
2,600\end{array}$ & $\begin{array}{l}4,600 \\
2,000\end{array}$ \\
\hline $\begin{array}{l}\text { Underflow from river-channel deposits } \\
\text { Santa Ynez River at the Narrows . . . . . } \\
\text { Southern Lompoc plain } \ldots \ldots \ldots\end{array}$ & $\begin{array}{r}600 \\
--\end{array}$ & $\begin{array}{r}1,500 \\
--\end{array}$ & $\begin{array}{r}1,500 \\
--\end{array}$ & 200 & $\begin{array}{l}1,700 \\
1,700\end{array}$ \\
\hline Irrigation-return flow $\ldots \ldots \ldots \ldots \ldots$ & 1,500 & 3,200 & 9,700 & ${ }^{5} 7,200$ & ${ }^{6} 7,800$ \\
\hline Average annual recharge $\ldots \ldots \ldots$ & 19,400 & 7,600 & 32,600 & 20,500 & 27,400 \\
\hline $\begin{array}{l}\text { Average annual precipitation } \\
\text { during indicated period (in.) } \ldots \ldots \ldots\end{array}$ & 19.3 & 7.9 & 13.5 & ${ }^{7} 12.5$ & ${ }^{8} 14.3$ \\
\hline \multicolumn{6}{|c|}{$\begin{array}{l}1 \text { Includes seepage loss along the reach between } 13 \text { th Street and Barrier gaging stations (fig. 5). } \\
{ }^{2} \text { Equals total amount of wastewater effluent discharged to the Santa Ynez River. } \\
{ }^{3} \text { Does not include estimates of recharge from streams entering the northern Lompoc plain (for example, Purisima } \\
\text { and Cebada Canyons). } \\
{ }^{4} \text { Calculated using infiltration estimates supplied by Santa Barbara County Water Agency. } \\
{ }^{5} \text { Calculated by Bright and others, 1992. This value is included in the calculation of average annual recharge. } \\
{ }^{6} \text { Equals difference between applied irrigation water and agricultural consumptive use (Ahlroth and others, 1977). } \\
{ }^{7} \text { Average annual precipitation for } 1968-72 \text { (U.S. Department of Commerce, Weather Bureau, 1954-76). } \\
{ }^{8} \text { Average annual precipitation for 1972-76 (U.S. Department of Commerce, Weather Bureau, 1954-76; National } \\
\text { Oceanic and Atmospheric Administration, 1976-88). }\end{array}$} \\
\hline
\end{tabular}


Table 3. Estimates of average annual discharge in the Lompoc area for selected periods

[Discharge values are in acre-feet. --, no data]

\begin{tabular}{|c|c|c|c|c|c|}
\hline $\begin{array}{l}\text { Discharge } \\
\text { source }\end{array}$ & $\begin{array}{c}1935-44 \\
\text { (Upson and } \\
\text { Thomasson, } \\
\text { 1951) }\end{array}$ & $\begin{array}{c}\text { 1947-51 } \\
\text { (Wilson, } \\
\text { 1959) }\end{array}$ & $\begin{array}{c}1957-62 \\
\text { (Evenson, } \\
1966)\end{array}$ & $\begin{array}{l}1972 \\
\text { (Miller, } \\
\text { 1976) }\end{array}$ & $\begin{array}{c}1975-76 \\
\text { (Ahlroth and } \\
\text { others } \\
1977)\end{array}$ \\
\hline Ground-water pumpage & ${ }^{1} 9,500$ & 121,400 & ${ }^{2} 27,400$ & ${ }^{2} 25,000$ & ${ }^{2} 26,000$ \\
\hline Transpiration by phreatophytes . & 5,100 & 3,000 & 6,000 & ${ }^{3} 3,200$ & 3,200 \\
\hline Underflow to ocean & 400 & 300 & 150 & 150 & 250 \\
\hline Seepage to the Santa Ynez River ..... & 1,500 & 100 & -- & 100 & -- \\
\hline Average annual total discharge & 16,500 & 24,800 & 33,550 & 28,450 & 29,450 \\
\hline
\end{tabular}

${ }^{1}$ Pumpage for Lompoc plain only.

${ }^{2}$ Pumpage for Lompoc plain, terrace, and upland (Mission Hills not included).

${ }^{3}$ Estimate based on vegetation data for 1964-75.

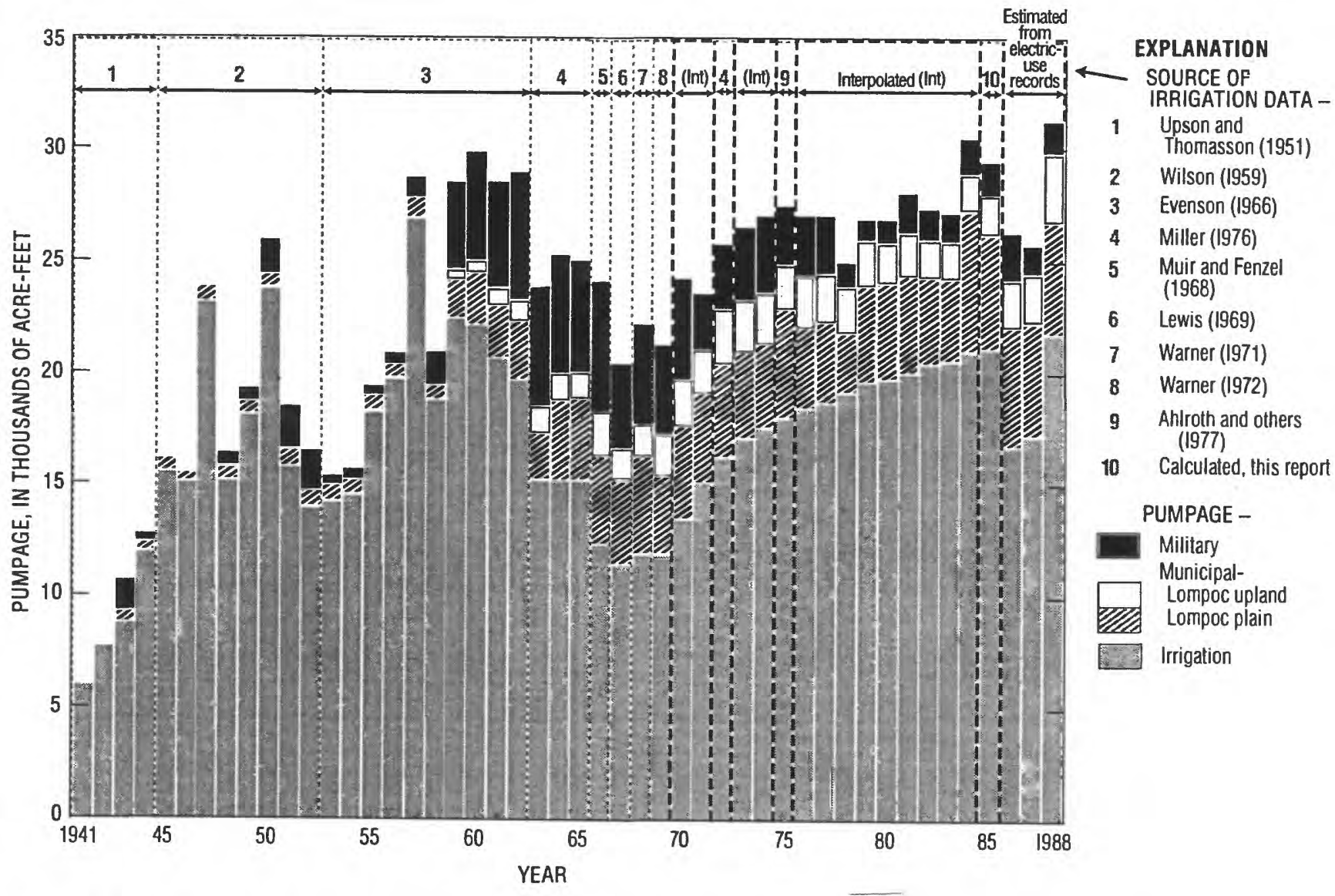

Figure 7. Components of annual pumpage in the Lompoc area, 1941-88. (Modified from Bright and others, 1992.) 
of 3,200 acre-ft by Miller (1976) was based on periodic surveys of phreatophytes along the Santa Ynez River by the U.S. Bureau of Reclamation. In these studies, it was concluded that transpiration by phreatophytes along the river ranged from approximately 2,800 to 3,200 acre-ft/yr for $1962-73$.

\section{Occurrence and Movement of Ground Water}

Prior to 1987, historical water-level data were collected almost exclusively from the main zone of the upper aquifer. However, during 1987-88, Bright and others (1992) collected hydrologic data that describe the vertical variation in hydraulic head between all zones in the upper aquifer and the lower aquifer. The results of Bright and others (1992) are used to describe ground-water movement within and between the upper and lower aquifers.

\section{Upper Aquifer}

On the basis of water-level measurements made in 1941, ground-water movement in the upper aquifer is from the Santa Ynez River, the principal source of recharge for the eastern plain, toward the west, where ground water eventually discharges to the Pacific Ocean. Comparison of potentiometric contours for the main zone in spring 1941 (fig. 8A), prior to significant pumping for irrigation and municipal and military supplies, with those in spring 1988 (fig. $8 B$ ), when pumping had increased substantially, indicates that hydraulic head in the main zone is 10 to $30 \mathrm{ft}$ lower throughout most of plain in 1988. The pumping has created a water-level depression around the city of Lompoc Municipal Supply Wells in the eastern plain (Bright and others, 1992, p. 20) and has locally reversed the direction of ground-water movement in the northeastern plain in comparison with 1941 conditions. The east-to-west movement of ground water observed in 1941 continues in the western part of the northeastern plain in 1988.

Long-term water-level hydrographs for wells in the eastern and western plain indicate that hydraulic head in the main zone can fluctuate more than $10 \mathrm{ft}$ on an annual basis (fig. 9). Comparison of the hydrographs indicates an overall declining trend in hydraulic head in the main zone from the 1930's to 1988. Net differences in the highest annual static water-level altitudes (fig. 9A,B) indicate that hydraulic head in the main zone declined approximately $20 \mathrm{ft}$ in the eastern plain and western plain.

A comparison of water levels in selected wells in the eastern, central, and western Lompoc plains shows that during the 1988 irrigation season (March-September), water-level fluctuations were similar in the shallow, middle, and main zones of the upper aquifer beneath the eastern plain (fig. 10A). In this area, ground water moves freely between all zones of the upper aquifer. In comparison, water levels in wells tapping the shallow zone beneath the central and western Lompoc plains fluctuated only slightly during the irrigation season, and the fluctuations generally differed from those in wells tapping the underlying zones (fig. 10B,C). Slight increases of hydraulic head in the shallow zone beneath these areas probably were due to infiltration of irrigation water. The large hydraulic-head differences that occurred between the shallow zone and underlying zones during the irrigation season, especially beneath the western plain, are primarily due to the thick deposits of silt and clay in the shallow zone that retard the movement of ground water between the shallow and middle zones. 


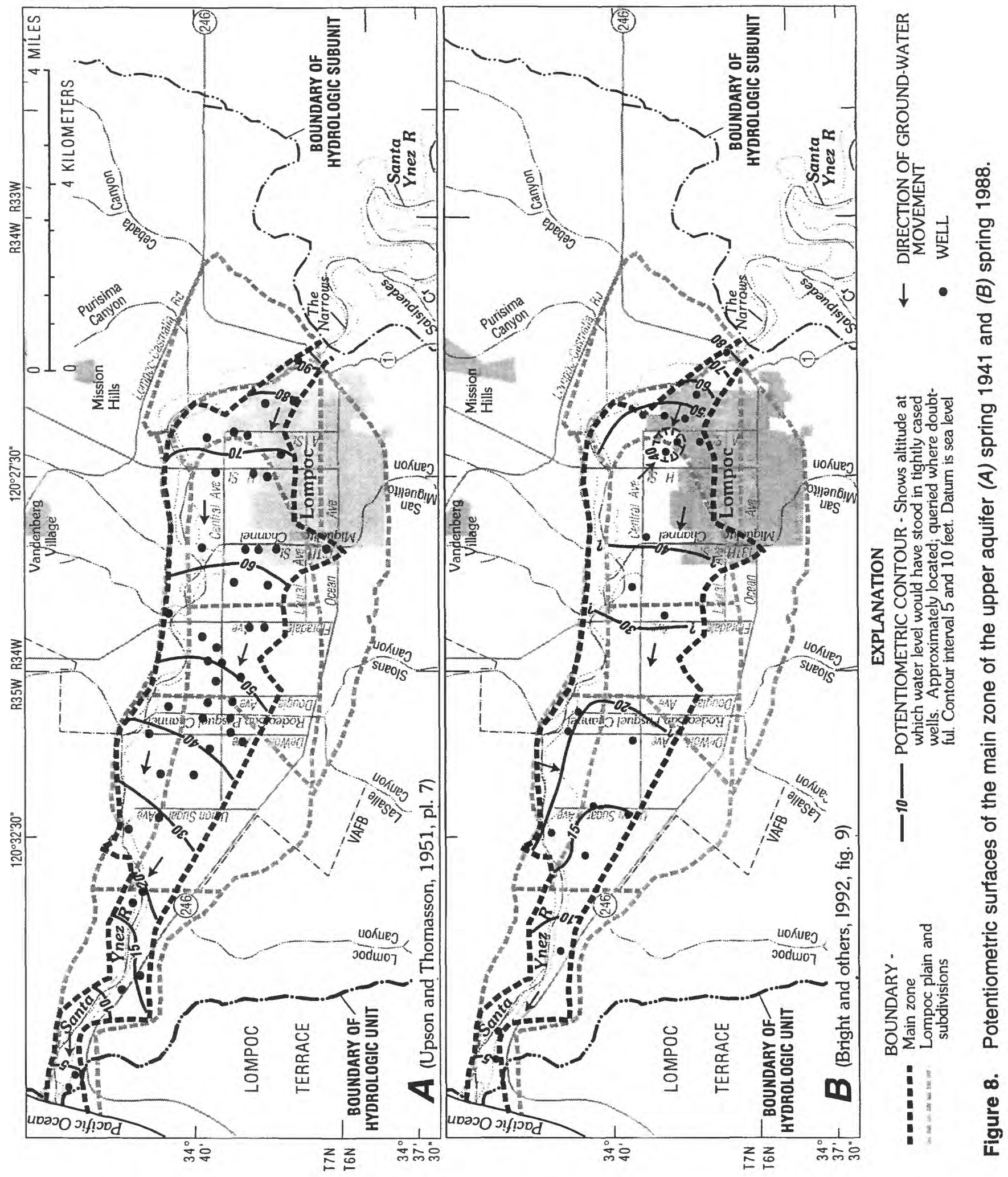



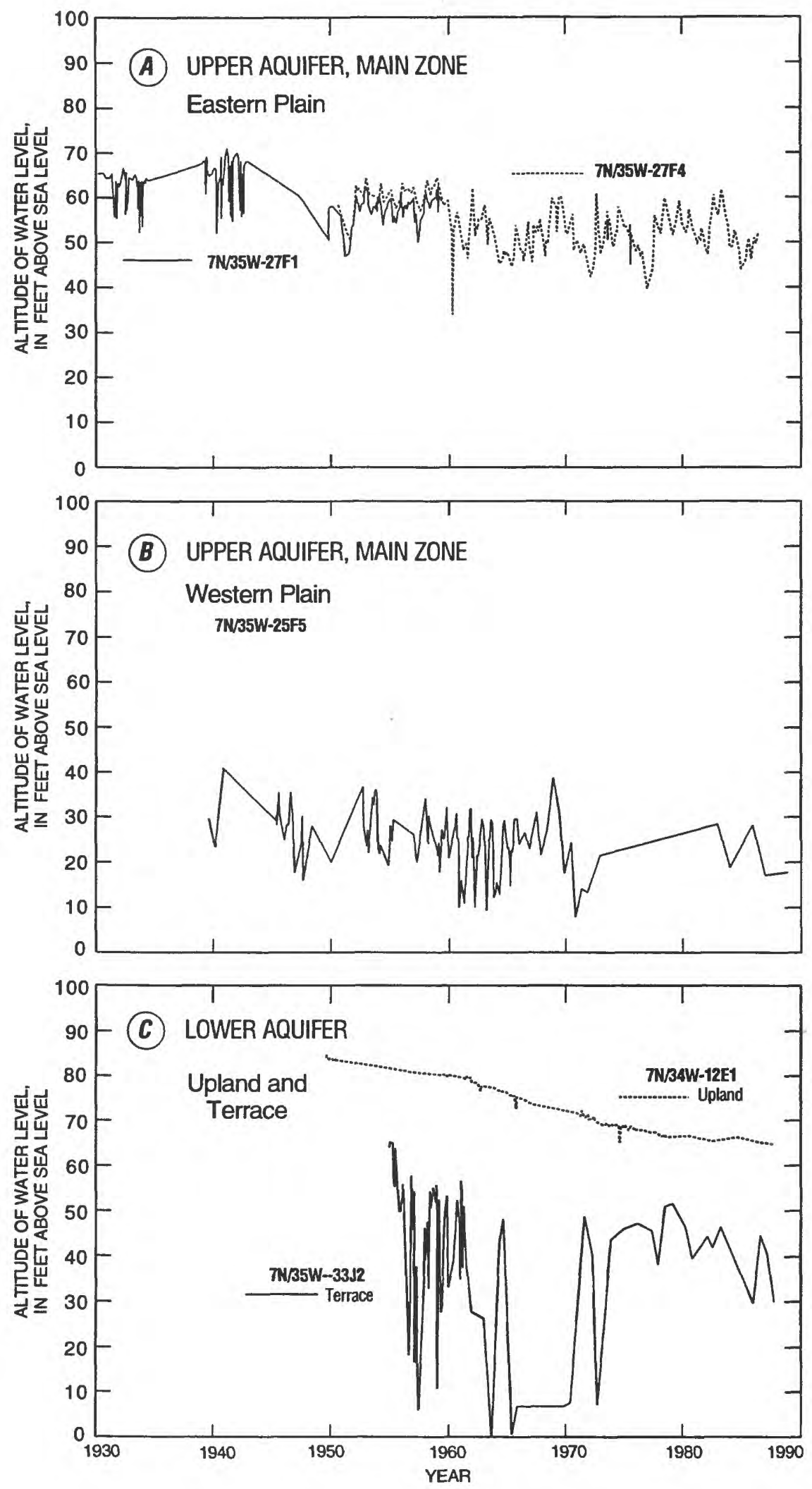

Figure 9. Altitude of water levels for selected wells in the upper aquifer (main zone) and lower aquifer, 1930-88. (Location of wells shown in figure 2.) 

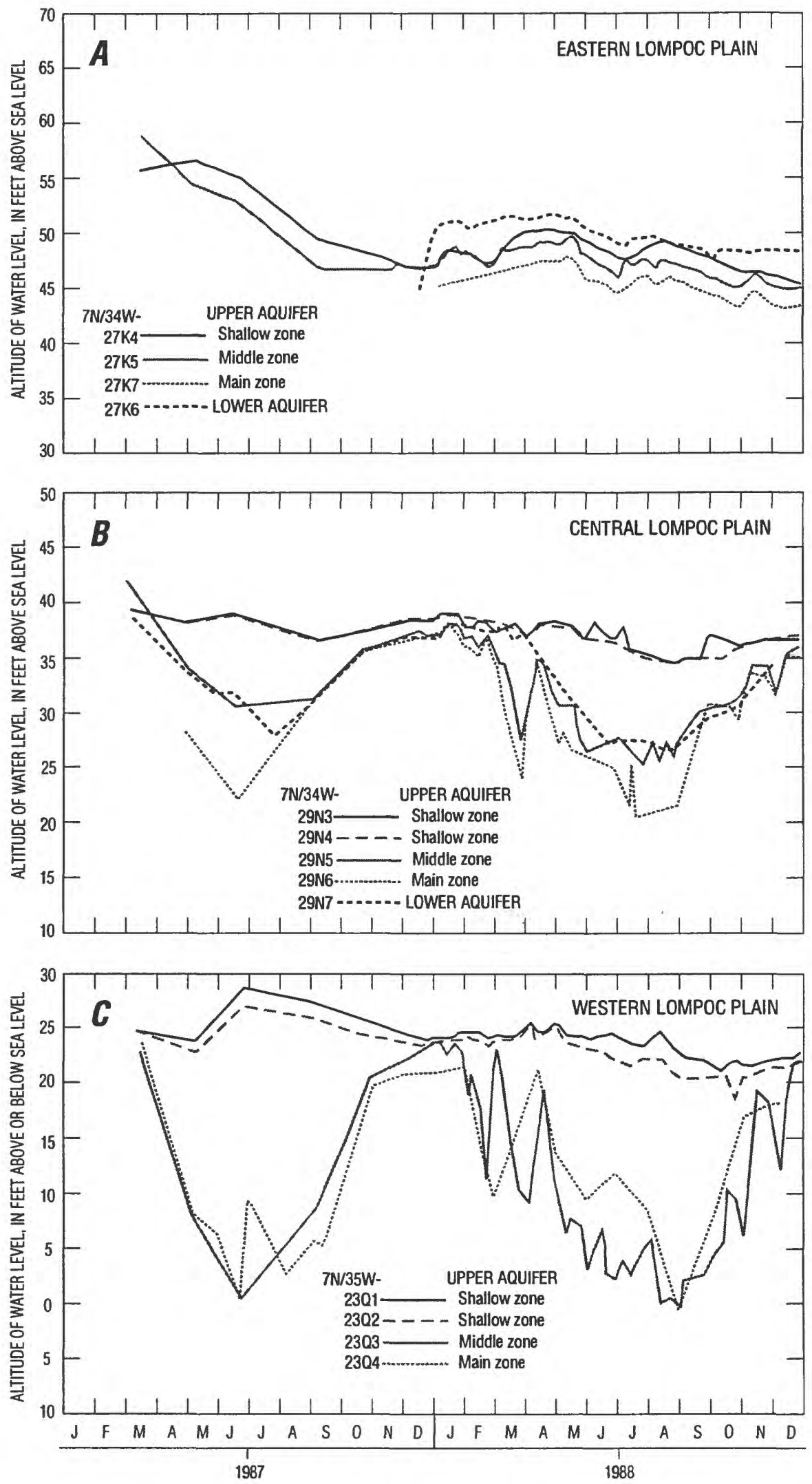

Figure 10. Altitude of water levels for selected wells in the upper aquifer (shallow, middle, and main zones) and lower aquifer, 1987-88. (Location of wells shown in figure 2.) 


\section{Lower Aquifer}

During 1987-88, ground water in the lower aquifer generally flowed from the Lompoc upland and Lompoc terrace toward the western plain (fig. 11). A subsurface ridge of consolidated rocks forms the boundary of the lower aquifer beneath the plain in this area (fig. 6 , section $C-C$ ), causing ground water to flow from the lower aquifer into the overlying middle and main zones of the upper aquifer. Ground-water flow from the lower aquifer has therefore been an important source of recharge to the upper aquifer (Upson and Thomasson, 1951, p. 152). This recharge occurs by upward flow beneath the Lompoc plain, and by lateral flow into the shallow, middle, and main zones along the perimeter of the upper aquifer (fig. 6, section $D-D^{\prime}$ ). Because the lower aquifer beneath the Lompoc plain historically has not been used as a source of water supply, it is probable that there has been little change in the general direction of ground-water movement.

Hydraulic head in the lower aquifer beneath the Lompoc upland and Lompoc terrace has declined since the late 1950's when ground-water pumping began for municipal and military supplies, respectively. Net differences in the highest annual static water-level altitudes (fig. $9 \mathrm{C}$ ) indicate that hydraulic heads declined about $20 \mathrm{ft}$ in the upland during 1949-88, and about $20 \mathrm{ft}$ in the terrace during 1958-87.

\section{Ground-Water Quality}

The availability of water-quality data for periods prior to 1987 is similar to that of water-level data; that is, the available data are almost exclusively for the main zone of the upper aquifer. However, water-quality data collected from all zones in the upper aquifer and from the lower aquifer in 1987-88 (Bright and others, 1992) show the areal and vertical variations in dissolved-solids concentrations that exist in the Lompoc area. Therefore, the water-quality analysis presented by Bright and others is summarized here.

\section{Upper Aquifer}

Periodic ground-water samples collected from the shallow zone beneath the eastern plain during the 1930's - in areas where there has been little, if any, history of agricultural activity - indicate that dissolved-solids concentrations were about the same as those measured in 1988 (less than 1,000 $\mathrm{mg} / \mathrm{L}$ ). However, dissolved-solids concentrations in samples collected from the shallow zone beneath irrigated areas in the northeastern and western plains in $1988(5,000 \mathrm{mg} / \mathrm{L})$ were higher than concentrations measured in the 1940's $(3,000 \mathrm{mg} / \mathrm{L})$, and they were markedly higher than in the eastern plain. In 1988, dissolved-solids concentrations in the shallow zone in irrigated areas beneath the northeastern, central, and western plains commonly were more than twice those in the middle and main zones, and several times higher than those in the lower aquifer (fig. 6, sections $C-C^{\prime}$ and $D-D$ ). These vertical differences in dissolved-solids concentration are primarily due to silt and clay deposits in the shallow zone that retard the downward movement of poor-quality ground water to the underlying middle zone.

Average dissolved-solids concentrations in the middle zone in 1987-88 were highest beneath the northeastern plain $(2,000-3,000 \mathrm{mg} / \mathrm{L}$; fig. 6 , section $C-C)$ and lowest beneath the western plain $(1,000-1,500 \mathrm{mg} / \mathrm{L}$; fig. 6 , section $C-C$ ). The source of the high dissolved-solids water in the northeastern plain is downward leakage from the shallow zone. However, in the western plain, the presence of water low in dissolved-solids concentration in the middle zone indicates that little, if any, high dissolved-solids water from the shallow zone recharges the middle zone in this area. This gradational decrease in dissolved-solids concentration from the northeastern to western plains parallels an increase in the thickness of silt and clay deposits (Miller, 1976). The correspondence between decreasing dissolved-solids concentration and increasing thickness of silt and clay deposits suggests, as do water-level data, that ground-water movement between the shallow and middle zones decreases from the eastern plain toward the western plain. 


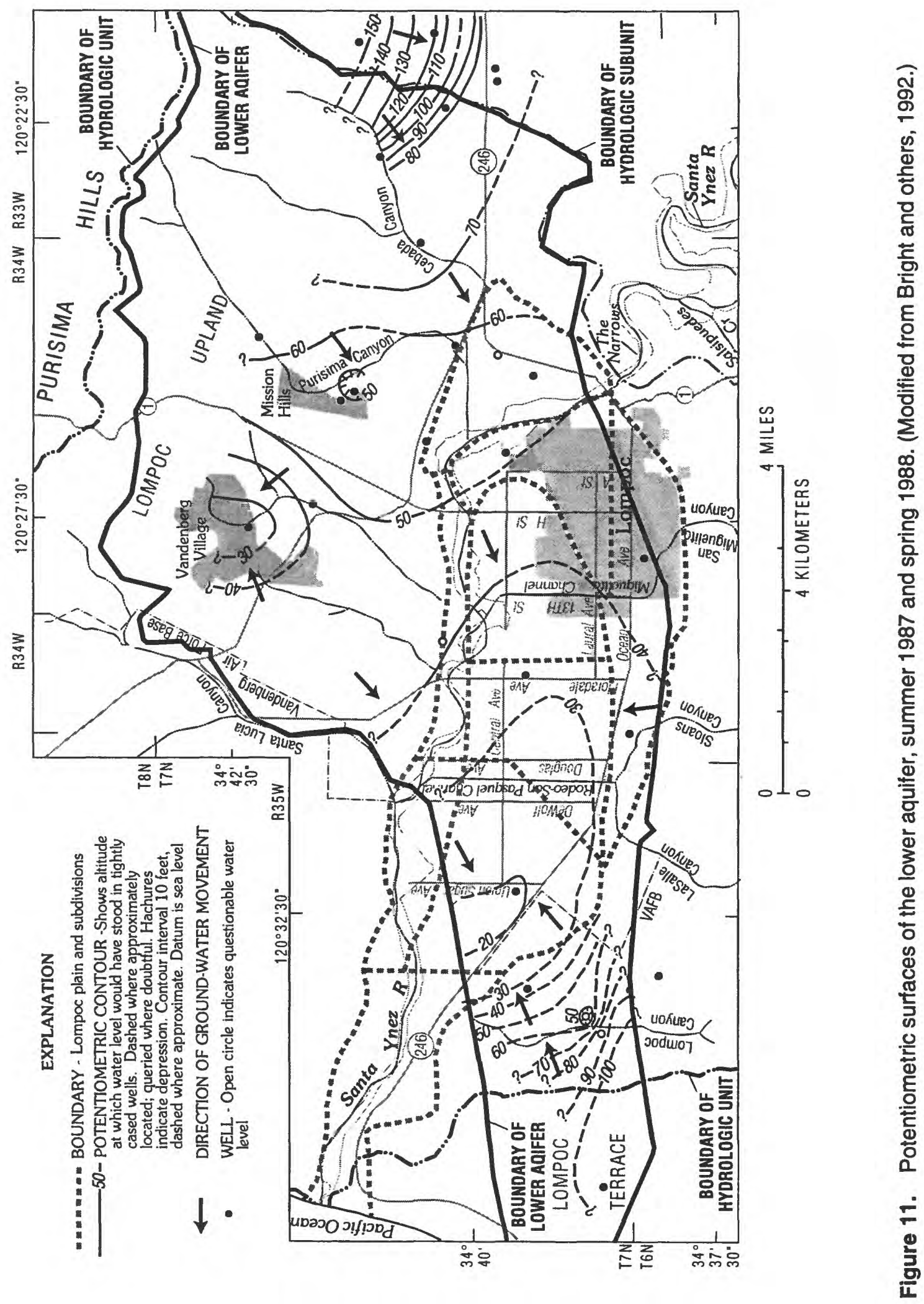


The dissolved-solids concentration in the main zone generally was less than $1,100 \mathrm{mg} / \mathrm{L}$ prior to the 1940's (Wilson, 1959, table 9). In areas adjacent to the Santa Ynez River, the dissolved-solids concentration in the main zone has not changed significantly (for example, in the eastern plain, well $7 \mathrm{~N} / 34 \mathrm{~W}-27 \mathrm{Q} 2$, fig. 12A). However, in most of the central and western plains the dissolved-solids concentration increased from less than $1,000 \mathrm{mg} / \mathrm{L}$ in the 1940 's to greater than $2,000 \mathrm{mg} / \mathrm{L}$ in early 1960 's (fig. 12B,C,D). This increase in dissolved-solids concentration corresponds to an increase in pumpage from the Lompoc Plain (fig. 7). The increase in pumpage induced the migration of poorquality water from the middle zone in the northeastern plain, where silt and clay layers are less extensive (fig. 6, section $C-C^{\prime}$ ), and subsequently caused the degradation of water quality in the main zone. Dissolved-solids concentrations have remained relatively constant since the 1960 's, - as has the pumpage - indicating that the chemical quality of water in the main zone is approaching a steady-state condition.

In the western plain, the main zone overlies, and is in direct contact with, both the lower aquifer and consolidated rocks (fig. 6, section $C-C$ ). Historical water-quality data indicate that, as ground water in the main zone moves westward from the central plain, its dissolved-solids concentration decreases as a result of the upward leakage of better quality water from the underlying lower aquifer (Evenson, 1964; Miller, 1976). However, where the lower aquifer is absent and the main zone is directly underlain by consolidated rocks, the dissolved-solids concentration increases dramatically. The consolidated rocks are of marine origin (table 1) and contain poor-quality water; available data from oil wells in the area indicate that the dissolved-solids concentration of water in the these rocks may be as high as $11,000 \mathrm{mg} / \mathrm{L}$ (D. A. Cole, Unocal Corporation, written commun., 1989). In 1994, monitor well $7 \mathrm{~N} / 35 \mathrm{~W}-23 \mathrm{E} 5$-E8 (fig. 2) was constructed in the western plain to provide information on the water quality of the consolidated rocks directly underlying the main zone. The dissolved-solids concentrations of two samples collected from this well in 1994 were 4,200 and $4,570 \mathrm{mg} / \mathrm{L}$. In this area, irrigation pumping from the main zone has induced the upward migration of this high dissolvedsolids concentration water through fractures in the consolidated rocks, resulting in increases in dissolved-solids concentration.

Dissolved-solids concentrations in the main zone of the upper aquifer historically have been highest in the western part of the coastal area and generally have exceeded 3,000 $\mathrm{mg} / \mathrm{L}$ (Miller, 1976, Berenbrock, 1988). Water-quality data (stable isotopes; sodium and chloride concentrations) collected in 1987-88 indicate that seawater was the source of the high dissolved-solids concentrations. The vertical migration of seawater from the overlying estuary was likely because the silt and clay layers of the shallow zone are relatively thin near the coast, and the difference in hydraulic head between zones indicates that water could have moved downward from the shallow zone to the main zone. Lateral migration of seawater into the upper aquifer was unlikely because hydraulic heads in the shallow and main zones were significantly above sea level and thus the direction of ground-water movement was toward the Pacific Ocean (Bright and others, 1992).

\section{Lower Aquifer}

Average dissolved-solids concentrations in the lower aquifer during 1987-88 generally were less than $1,000 \mathrm{mg} / \mathrm{L}$ throughout the Lompoc area (fig. 6, sections $C-C$ and $D-D$ ). Available historical data indicate that dissolved-solids concentrations in the lower aquifer have not changed significantly since the early 1960's beneath the Lompoc upland. Although no data are available for the lower aquifer beneath the Lompoc plain prior to 1987, it is probable that there has been little change in the ground-water quality. 

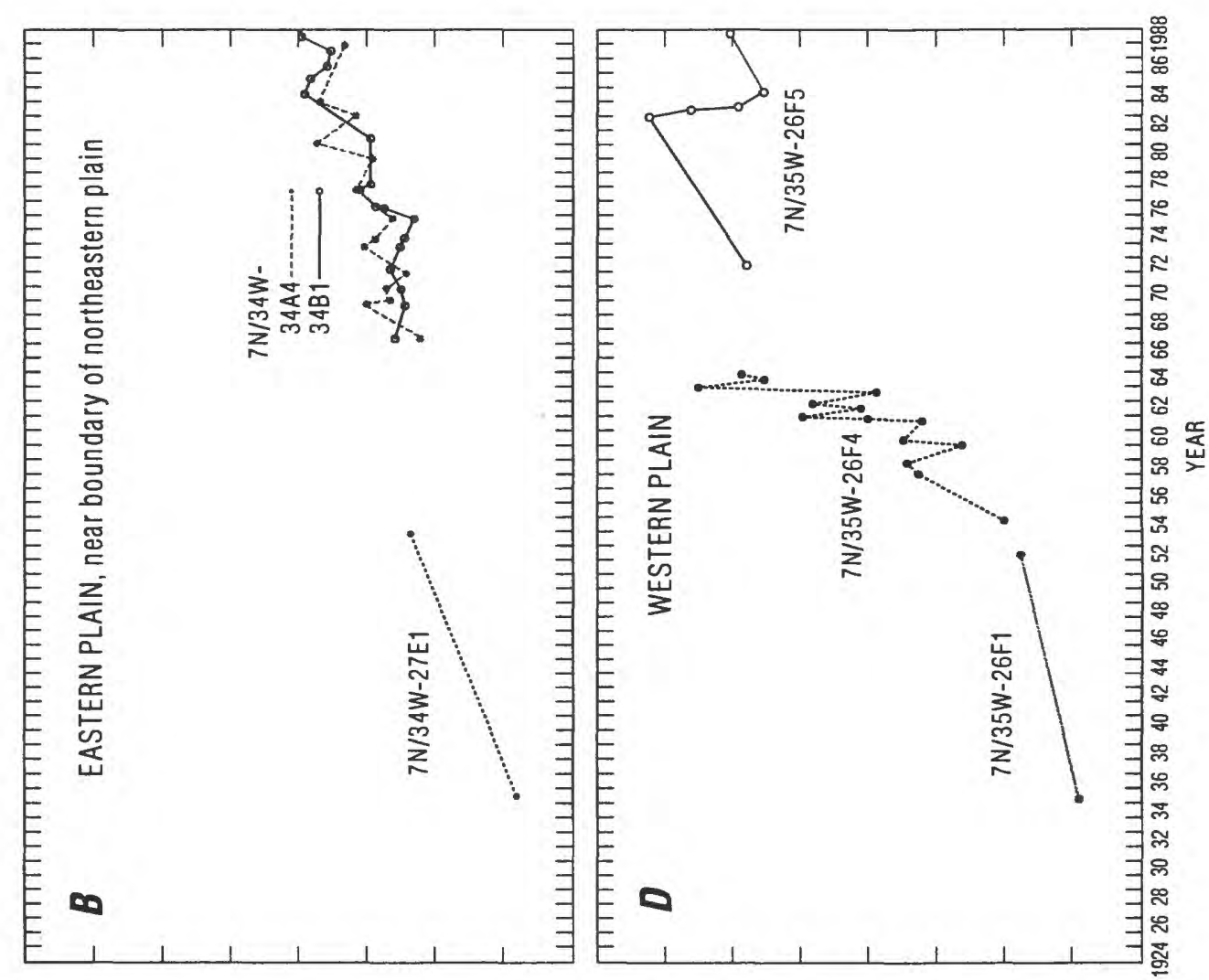

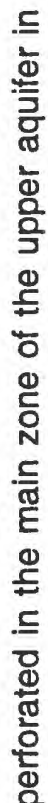

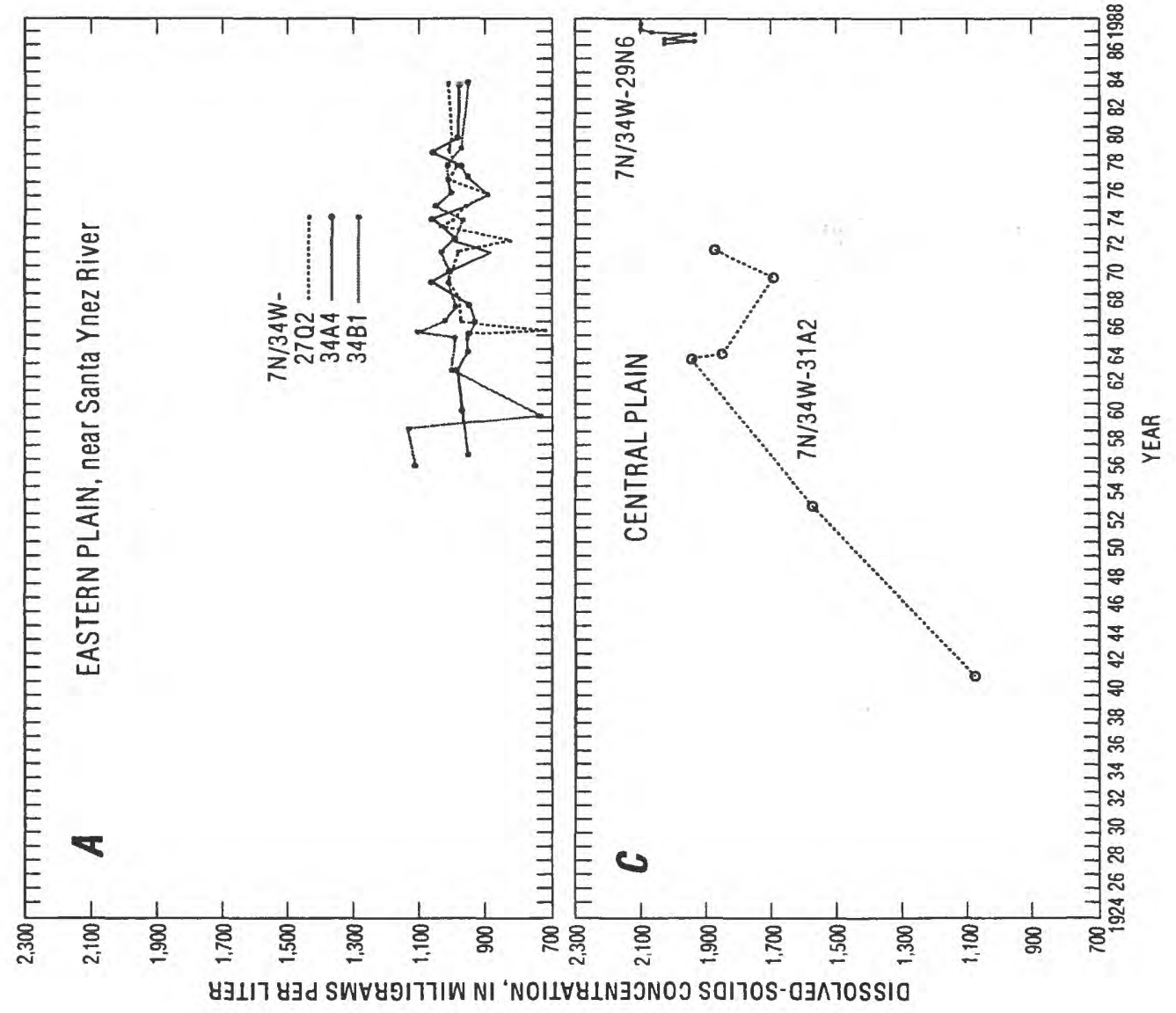

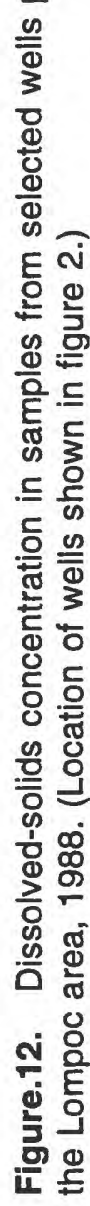




\section{NUMERICAL SIMULATION OF GROUND-WATER FLOW AND SOLUTE TRANSPORT}

Numerical models were developed to increase understanding of the ground-water flow system in the Lompoc area. A three-dimensional ground-water flow model was used to simulate hydraulic head in the upper and lower aquifers, and to determine the vertical and lateral fluid fluxes to and from the main zone of the upper aquifer. A two-dimensional solute-transport model was used to simulate dissolved-solids concentrations in the main zone of the upper aquifer. The models were calibrated using a dual-calibration strategy in which both simulated hydraulic heads and dissolved-solids concentrations were used to determine the most accurate match with observed data. Once calibrated, these models can be used for evaluating ground-water management strategies. Because of the complex geohydrologic relations in the ground-water system and the scarcity of data, these mathematical models cannot exactly duplicate the actual system; thus, the use of simplifying assumptions and approximations is required. Furthermore, it must be recognized that these models are only as accurate as the assumptions and data used in their development.

A modular three-dimensional finite-difference ground-water flow model (MODFLOW) developed by the US Geological Survey (McDonald and Harbaugh, 1988) was used to simulate ground-water flow in the Lompoc area. The strongly implicit procedure (SIP) (McDonald and Harbaugh, 1988) was utilized for the solution of the finite-difference approximating equations generated by the flow model. A full explanation of the physical and mathematical concepts on which the model is based, and an explanation of how these concepts were incorporated in the modular structure of the computer code, are given by McDonald and Harbaugh (1988). SUTRA (saturated-unsaturated transport), a twodimensional finite-element simulation computer code for ground-water flow and solute transport developed by the U.S. Geological Survey (Voss, 1984), was used to simulate ground-water flow and solute transport in the main zone of the upper aquifer. A full explanation of the physical and mathematical concepts on which the model is based is presented by Voss (1984).

\section{Flow-Model Construction}

The three-dimensional finite-difference model MODFLOW was used to simulate flow in the Lompoc area. In order to numerically simulate ground-water flow in the aquifer system, it is necessary to (1) divide the aquifer system into a grid, (2) determine the boundary conditions, (3) estimate the rates and distribution of recharge and discharge, and (4) estimate the aquifer properties within the model area.

\section{Model Grid}

The aquifer system is divided into four horizontal layers of square cells all with side lengths of $1,320 \mathrm{ft}(0.25 \mathrm{mi})$ (fig. 13). Each layer is continuous, representing different zones or aquifers. Layer 1 is the uppermost layer and has a thickness of $50 \mathrm{ft}$. Layer 2 underlies Layer 1 throughout the model area and has a thickness of $40 \mathrm{ft}$. Layer 3 underlies layer 2 throughout most of the model and has a thickness of $85 \mathrm{ft}$. Layer 4 is the lowermost layer in most of the model area and has a variable thickness. For the Lompoc plain, the upper three layers represent the shallow, middle, and main zones of the upper aquifer, and the bottom layer represents the lower aquifer (fig. 14). For the Lompoc uplands and terrace, all four layers represent the lower aquifer (fig. 14). Average values for the physical and hydraulic characteristics of the aquifer system within a cell are assigned to the cell. The model calculates the average hydraulic head within each cell. 

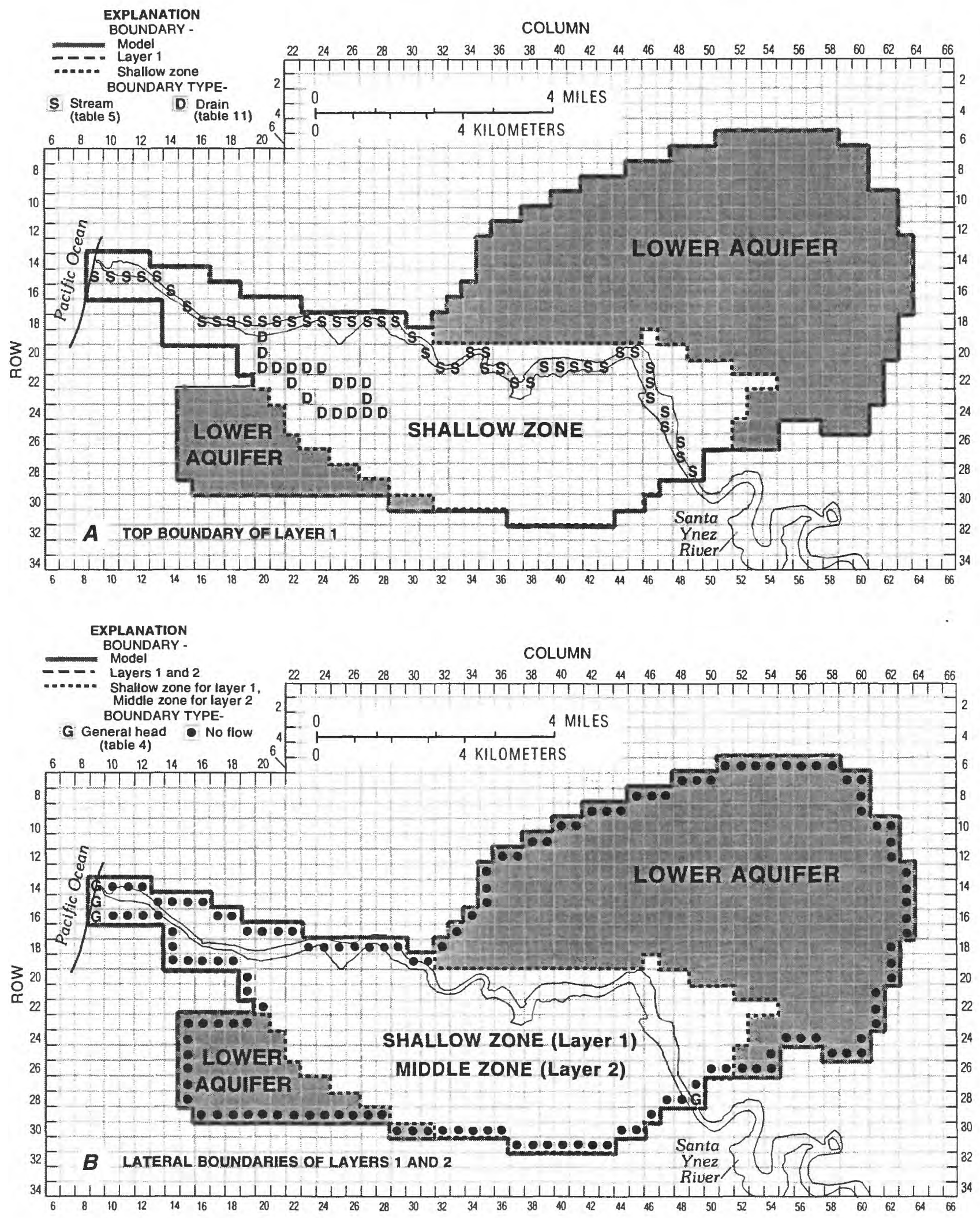

Figure 13. Model grid and boundary conditions for layers 1-4 of the ground-water flow model in the Lompoc area. 

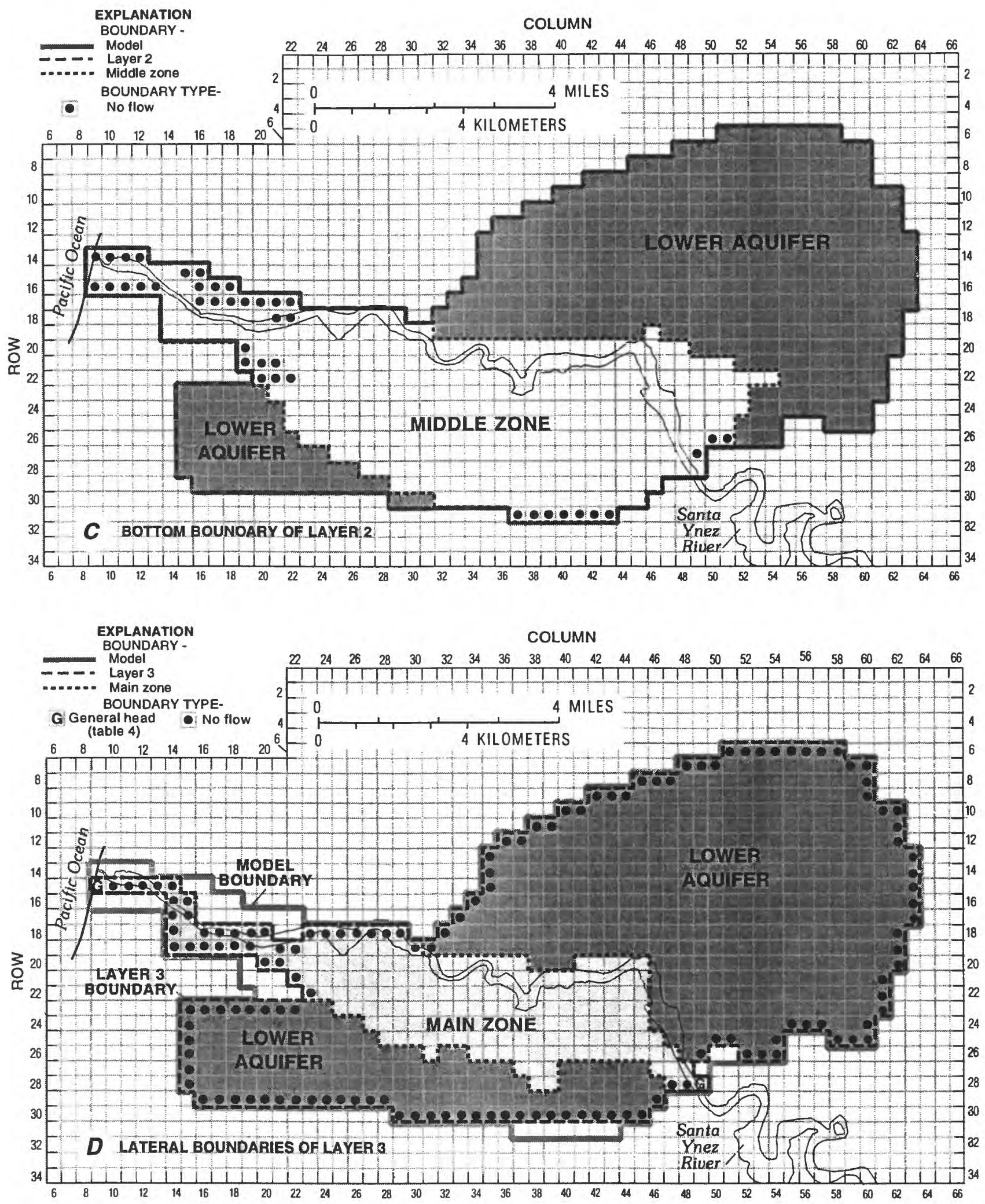

Figure 13.-Continued. 

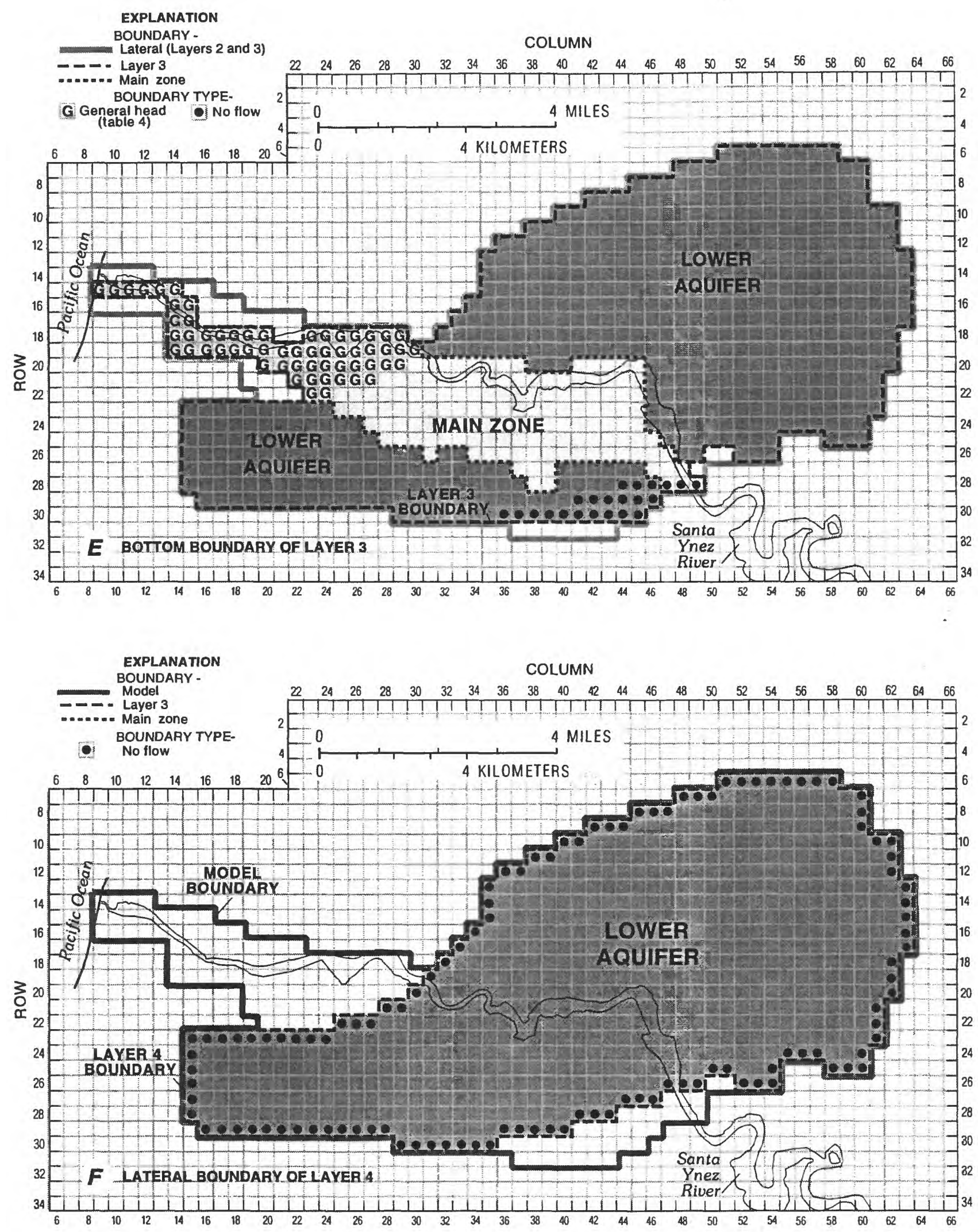

Figure 13.-Continued. 

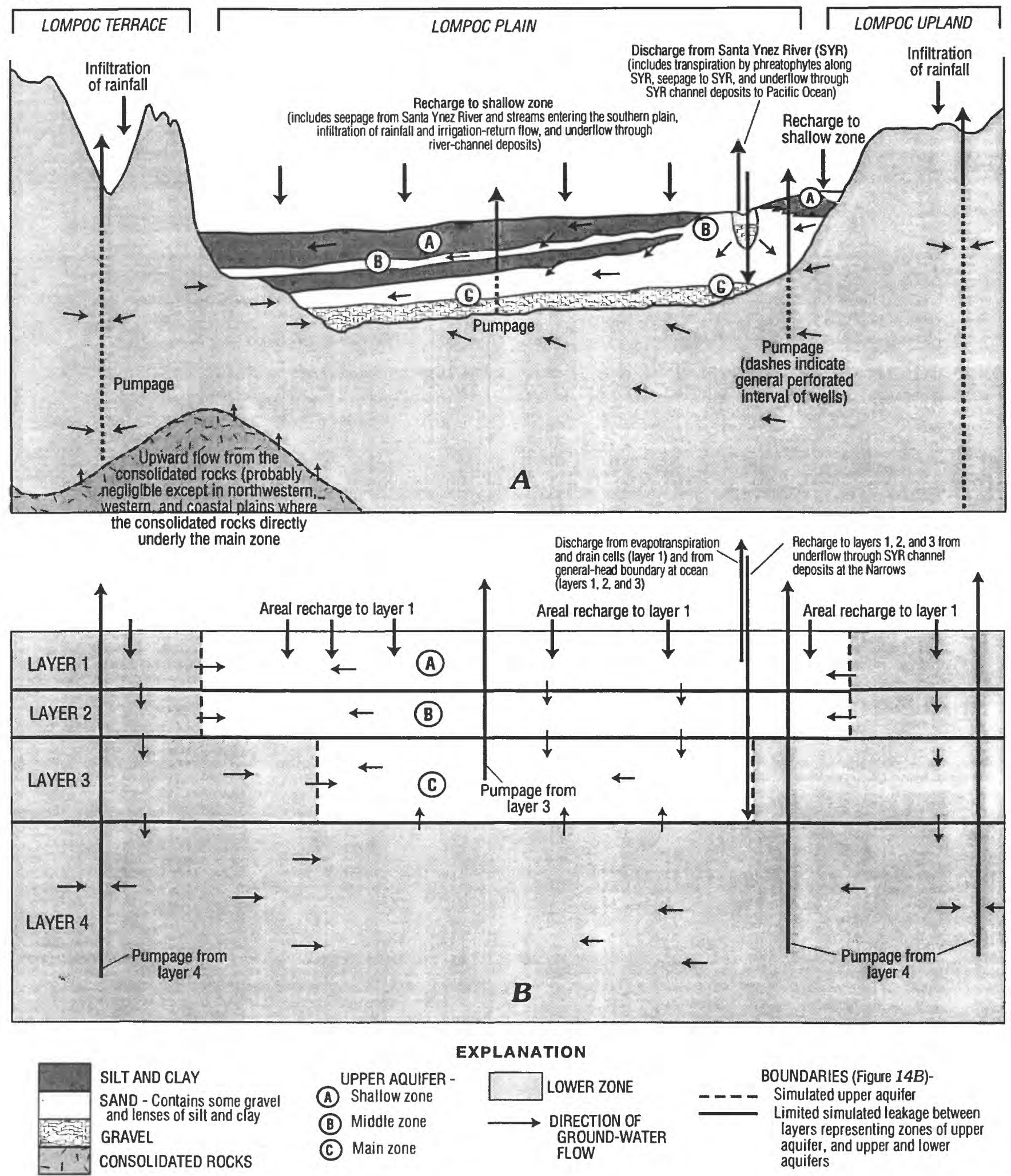

SILT AND CLAY

SAND - Contains some gravel and lenses of silt and clay GRAVEL

CONSOLIDATED ROCKS
UPPER AQUIFER -

(A) Shallow zone

(B) Middle zone

(C) Main zone
EXPLANATION

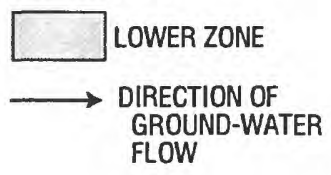

BOUNDARIES (Figure 14B)-

- - - - Simulated upper aquifer

- Limited simulated leakage between layers representing zones of upper aquifer, and upper and lowe aquifers

Figure 14. Conceptualization of the ground-water flow system in the Lompoc area. 


\section{Boundary Conditions}

No-flow and general-head boundary conditions are used to simulate the aquifer system's interaction with the regional flow system. No-flow boundaries are used around and below the modeled area to represent contact with consolidated rocks and ground-water divides (fig. 13). Although the consolidated rocks are not impermeable, the quantity of water contributed by them probably is negligible except in the northwestern, western, and coastal plains where the consolidated rock directly underlie the main zone. Low-permeability deposits within the lower aquifer probably retard the upward migration of ground water from fractures in the consolidated rocks. This assumption is indirectly supported by water-quality data from previous studies which suggest that consolidated rocks along the perimeter of the basin have not caused ground-water-quality degradation in the unconsolidated waterbearing deposits in these areas (Wilson, 1959; Miller, 1976; Berenbrock, 1988; Bright and others, 1992), except in the western and coastal plains where they directly underlay the main zone. The ground-water divides constituting the eastern and southwestern edges of the modeled area (fig. 11) are represented as no-flow boundaries (fig. 13).

General-head boundaries are used to simulate underflow from Santa Ynez River deposits at the Narrows and at the offshore extension of the aquifer system beneath the Pacific Ocean at the westernmost edge of the model. General-head boundaries are also used to simulate upward flow from the consolidated rocks that underlie the main zone (layer 3 ) in the western and coastal plains (table 4). A general-head boundary simulates a source of water outside the model area that either supplies water to, or receives water from, the adjacent cells at a rate proportional to the hydraulic-head differences between the source and model cell. General-head boundaries are simulated in the model using the general-head boundary package (MacDonald and Harbaugh, 1988 p. 11-1).

The rate at which water is exchanged between the model cell and the outside source or sink is given by

$$
Q=C(H B-h)
$$

where

$Q$ is the rate of flow into or out of the model cell $\left[\mathrm{L}^{3} \mathrm{~T}^{-1}\right]$,

$C$ is the conductance between the external source or sink and the model cell $\left[\mathrm{L}^{2} \mathrm{~T}^{-1}\right]$,

$H B$ is the head assigned to the external source or sink [L], and

$h$ is the hydraulic head within the model cell [L].

Values of $C$ were initially calculated from

$$
C=K W b / L
$$

where

$K$ is the hydraulic conductivity between the model cell and the boundary head [ $\left[\mathrm{TT}^{-1}\right]$,

$W$ is the cell width perpendicular to flow [L],

$b$ is the cell thickness (aquifer thickness) perpendicular to flow [L], and

$L \quad$ is the distance between the model cell center and the specied boundary head measured parallel to flow [L].

The final values of $C$ (table 4) are determined by the model calibration. The boundary head $(H B)$ in the Santa Ynez River deposits at the Narrows is set equal to the measured water-level altitude at well $6 \mathrm{~N} / 34 \mathrm{~W}-2 \mathrm{~A} 1$ and $\mathrm{A6}$ (fig. 2). $H B$ of the offshore deposits is set equal to the freshwater equivalent to the overlying column of saltwater (table 4). Freshwater-equivalent head is calculated by dividing the depth to the center of a model cell below sea level by 40 . $H B$ values for the consolidated rocks are assumed to be the same as those used in the main zone steady-state model (no measured data are available for this area). 
Table 4. Parameters for the general-head boundary package

[ft, foot; $\mathrm{ft}^{2} / \mathrm{d}$, square foot per day]

\begin{tabular}{|c|c|c|c|c|c|}
\hline Layer & Row & Column & $\begin{array}{l}\text { Boundary } \\
\text { head, } H B \\
(\mathrm{ft})\end{array}$ & $\begin{array}{c}\text { Conductance, } \\
C \\
\left(\mathrm{ft}^{2} / \mathrm{d}\right)\end{array}$ & Boundary \\
\hline 1 & 14 & 9 & 0.62 & 970 & Western boundary at Surf \\
\hline 2 & 14 & 9 & 1.75 & 103 & Western boundary at Surf \\
\hline 1 & 15 & 9 & .62 & 3,000 & Western boundary at Surf \\
\hline 2 & 15 & 9 & 1.75 & 400 & Western boundary at Surf \\
\hline 3 & 15 & 9 & 3.31 & 14,545 & Western boundary at Surf \\
\hline 1 & 16 & 9 & .7 & 970 & Western boundary at Surf \\
\hline 2 & 16 & 9 & 2.0 & 103 & Western boundary at Surf \\
\hline 1 & 28 & 49 & variable $^{1}$ & 1,697 & Eastern boundary at Narrows \\
\hline 2 & 28 & 49 & variable $^{1}$ & 1,316 & Eastern boundary at Narrows \\
\hline 3 & 28 & 49 & variable $^{1}$ & 2,630 & Eastern boundary at Narrows \\
\hline 3 & 15 & 9 & 4.0 & 470.5 & Consolidated rocks \\
\hline 3 & 15 & 10 & 4.3 & 470.5 & Consolidated rocks \\
\hline 3 & 15 & 11 & 4.7 & 470.5 & Consolidated rocks \\
\hline 3 & 15 & 12 & 5.2 & 470.5 & Consolidated rocks \\
\hline 3 & 15 & 13 & 6.2 & 470.5 & Consolidated rocks \\
\hline 3 & 15 & 14 & 7.6 & 470.5 & Consolidated rocks \\
\hline 3 & 16 & 14 & 9.0 & 470.5 & Consolidated rocks \\
\hline 3 & 16 & 15 & 9.8 & 470.5 & Consolidated rocks \\
\hline 3 & 17 & 14 & 10.3 & 470.5 & Consolidated rocks \\
\hline 3 & 17 & 15 & 10.5 & 470.5 & Consolidated rocks \\
\hline 3 & 18 & 14 & 11.3 & 470.5 & Consolidated rocks \\
\hline 3 & 18 & 15 & 11.8 & 470.5 & Consolidated rocks \\
\hline 3 & 18 & 16 & 12.9 & 470.5 & Consolidated rocks \\
\hline 3 & 18 & 17 & 14.2 & 470.5 & Consolidated rocks \\
\hline 3 & 18 & 18 & 15.5 & 470.5 & Consolidated rocks \\
\hline 3 & 18 & 19 & 16.8 & 470.5 & Consolidated rocks \\
\hline 3 & 18 & 20 & 18.0 & 470.5 & Consolidated rocks \\
\hline 3 & 18 & 23 & 24.9 & 470.5 & Consolidated rocks \\
\hline 3 & 18 & 24 & 25.7 & 470.5 & Consolidated rocks \\
\hline 3 & 18 & 25 & 27.0 & 470.5 & Consolidated rocks \\
\hline 3 & 18 & 26 & 28.3 & 470.5 & Consolidated rocks \\
\hline 3 & 18 & 27 & 29.4 & 470.5 & Consolidated rocks \\
\hline 3 & 18 & 28 & 30.1 & 470.5 & Consolidated rocks \\
\hline 3 & 18 & 29 & 29.5 & 470.5 & Consolidated rocks \\
\hline 3 & 19 & 14 & 11.9 & 470.5 & Consolidated rocks \\
\hline 3 & 19 & 15 & 12.3 & 470.5 & Consolidated rocks \\
\hline 3 & 19 & 16 & 13.2 & 470.5 & Consolidated rocks \\
\hline 3 & 19 & 17 & 14.4 & 470.5 & Consolidated rocks \\
\hline 3 & 19 & 18 & 15.7 & 470.5 & Consolidated rocks \\
\hline
\end{tabular}


Table 4. Parameters for the general-head boundary package-Continued

\begin{tabular}{|c|c|c|c|c|c|}
\hline Layer & Row & Column & $\begin{array}{c}\text { Boundary } \\
\text { head, } H B \\
\text { (ft) }\end{array}$ & $\begin{array}{c}\text { Conductance, } \\
C \\
\left(\mathrm{ft}^{2} / \mathrm{d}\right)\end{array}$ & Boundary \\
\hline 3 & 19 & 19 & 17.4 & 470.5 & Consolidated rocks \\
\hline 3 & 19 & 20 & 19.4 & 470.5 & Consolidated rocks \\
\hline 3 & 19 & 21 & 21.3 & 470.5 & Consolidated rocks \\
\hline 3 & 19 & 22 & 23.1 & 470.5 & Consolidated rocks \\
\hline 3 & 19 & 23 & 24.7 & 470.5 & Consolidated rocks \\
\hline 3 & 19 & 24 & 26.0 & 470.5 & Consolidated rocks \\
\hline 3 & 19 & 25 & 27.3 & 470.5 & Consolidated rocks \\
\hline 3 & 19 & 26 & 28.6 & 470.5 & Consolidated rocks \\
\hline 3 & 19 & 27 & 29.8 & 470.5 & Consolidated rocks \\
\hline 3 & 19 & 28 & 31.0 & 470.5 & Consolidated rocks \\
\hline 3 & 19 & 29 & 32.2 & 470.5 & Consolidated rocks \\
\hline 3 & 19 & 30 & 34.2 & 470.5 & Consolidated rocks \\
\hline 3 & 20 & 20 & 21.1 & 470.5 & Consolidated rocks \\
\hline 3 & 20 & 21 & 22.0 & 470.5 & Consolidated rocks \\
\hline 3 & 20 & 22 & 23.8 & 470.5 & Consolidated rocks \\
\hline 3 & 20 & 23 & 25.2 & 470.5 & Consolidated rocks \\
\hline 3 & 20 & 24 & 26.5 & 470.5 & Consolidated rocks \\
\hline 3 & 20 & 25 & 27.9 & 470.5 & Consolidated rocks \\
\hline 3 & 20 & 26 & 29.2 & 470.5 & Consolidated rocks \\
\hline 3 & 20 & 27 & 30.6 & 470.5 & Consolidated rocks \\
\hline 3 & 20 & 28 & 32.0 & 470.5 & Consolidated rocks \\
\hline 3 & 20 & 29 & 33.6 & 470.5 & Consolidated rocks \\
\hline 3 & 21 & 22 & 24.9 & 470.5 & Consolidated rocks \\
\hline 3 & 21 & 23 & 26.1 & 470.5 & Consolidated rocks \\
\hline 3 & 21 & 24 & 27.3 & 470.5 & Consolidated rocks \\
\hline 3 & 21 & 25 & 28.6 & 470.5 & Consolidated rocks \\
\hline 3 & 21 & 26 & 30.0 & 470.5 & Consolidated rocks \\
\hline 3 & 21 & 27 & 31.5 & 470.5 & Consolidated rocks \\
\hline 3 & 22 & 23 & 27.2 & 470.5 & Consolidated rocks \\
\hline 3 & 22 & 24 & 28.0 & 470.5 & Consolidated rocks \\
\hline
\end{tabular}

${ }^{1}$ Boundary head is varied on basis of seasonal water-level measurements collected at wells $6 \mathrm{~N} / 34 \mathrm{~W}-2 \mathrm{~A} 1$ and A6, and is shown on the following page. 
Table 4. Parameters for the general-head boundary package - Continued

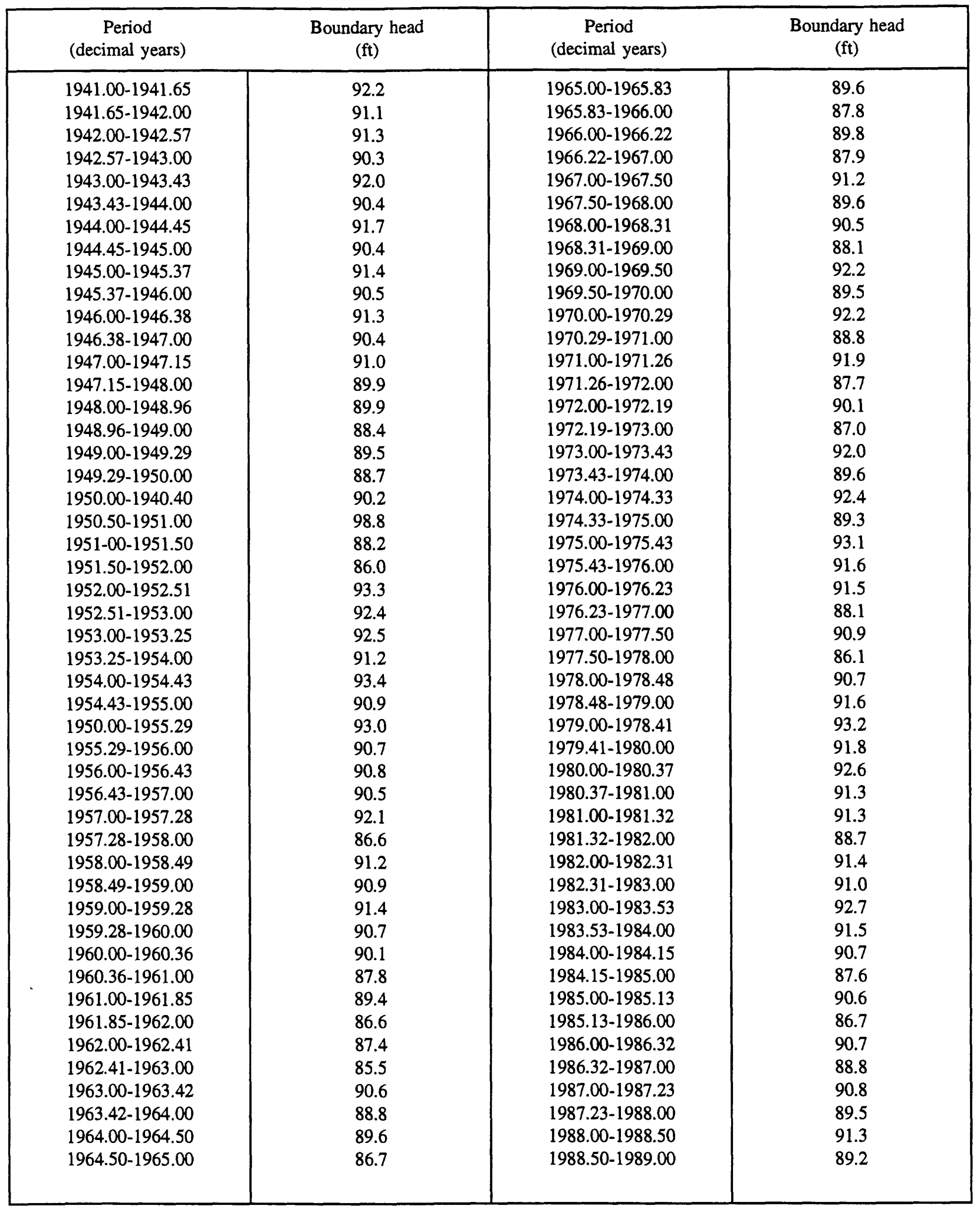




\section{Stream-Aquifer Relations}

The Streamflow-Routing Package (Prudic, 1989), is used to model the interaction of the Santa Ynez River with the aquifer system. This program is not a true surface-water flow model but rather is an accounting program that tracks the flow in one or more streams that interact with ground water (Prudic, 1989). The Santa Ynez River was divided into three stream segments-the first segment extends from the narrows to the Lompoc Regional Wastewater Treatment Plant, the second segment represents the outfall from the treatment plant, and the third segment extends from the treatment plant to the Pacific Ocean. Each segment consists of a group of reaches connected in downstream order. A stream reach corresponds to individual cells in the finite-difference model grid (table 5). Leakage is calculated for each reach on the basis of the following equation:

$$
Q_{L}=\operatorname{CSTR}\left(H_{s}-H_{a}\right)
$$

where

$Q_{L}$ is the leakage to or from the aquifer through the streambed $\left[\mathrm{L}^{3} \mathrm{~T}^{-1}\right]$,

$\mathrm{H}_{\mathrm{s}}$ is the head in the stream [L],

$H_{a}$ is the head on aquifer side of the streambed [L], and

CSTR is the conductance of the streambed $\left[\mathrm{L}^{2} \mathrm{~T}^{-1}\right]$.

CSTR is equal to the vertical hydraulic conductivity of the streambed times the product of the width of the stream and its length (streambed area) divided by the thickness of the streambed. For most of the stream reaches, the vertical hydraulic conductivity of the streambed is assumed to be equal to the Transmissivity assigned to the model cell directly underlying the stream reach (fig. 22, presented in the "Aquifer Properties" section) divided by $50 \mathrm{ft}$ (the thickness of layer 1) divided by the horizontal to vertical anisotropy for that cell (fig. 23, presented in the "Aquifer Properties" section). For the stream reaches in the western part of the coastal area (stream reaches 25-31), the vertical hydraulic conductivity was assigned a value of $0.1 \mathrm{ft} / \mathrm{d}$ to represent the silt and clay layers in the upper part of the shallow zone. The average streambed area is $478,014 \mathrm{ft}^{2}$ per cell, and the average bed thickness is $20 \mathrm{ft}$.

The head on the aquifer side of the streambed $\left(H_{a}\right)$ is equal to the head in the model cell beneath the stream reach. If the head in the aquifer is less than the streambed elevation, then $H_{a}$ is equal to the elevation of the bottom of the streambed. $H_{s}$ is determined by adding the elevation of the top of the streambed to the river depth, $d$, determined from Manning's formula assuming a vertical-sided channel with a flat bottom:

$$
d=\left[\frac{Q n}{C w \sqrt{s}}\right]^{3 / 5}
$$

where

$d$ is stream depth (L),

$Q$ is stream discharge $\left(\mathrm{L}^{3} / \mathrm{T}\right)$

$n$ is Manning's roughness coefficient (dimensionless),

$C$ is a constant $\left(\mathrm{L}^{1 / 3} / \mathrm{T}\right)$, which is 1.486 for units of cubic feet per second,

$w$ is channel width (L), and

$s$ is the gradient of the water surface $(\mathrm{L} / \mathrm{L})$.

A value of 0.045 is used for $n$ on the basis of a visual match of the channel of the Santa Ynez River with photographs of representative channels presented by Barnes (1977). The channel width (w) is assumed to be $300 \mathrm{ft}$ for all values of stream discharge. The gradient of the water surface $(s)$ is assumed to be equal to the average gradient of the streambed $1.537 \times 10^{-3} \mathrm{ft} / \mathrm{ft}$. 
Table 5. Channel characteristics used in the streamflow-routing package

[ft ${ }^{2} / d$, square foot per day; $f t$ foot; $f t / d$, foot per day]

\begin{tabular}{|c|c|c|c|c|c|c|}
\hline $\begin{array}{l}\text { Riverbed } \\
\text { segment }\end{array}$ & $\begin{array}{l}\text { Reach of } \\
\text { riverbed } \\
\text { segment }\end{array}$ & $\begin{array}{c}\text { Model } \\
\text { row }\end{array}$ & $\begin{array}{l}\text { Model } \\
\text { column }\end{array}$ & $\begin{array}{c}\text { Riverbed } \\
\text { conductance } \\
\left(\mathrm{ft}^{2} / \mathrm{d}\right)\end{array}$ & $\begin{array}{l}\text { Riverbed } \\
\text { elevation } \\
(\mathrm{ft})\end{array}$ & $\begin{array}{c}\text { Vertical } \\
\text { hydraulic } \\
\text { conductivity } \\
\text { (ft/d) }\end{array}$ \\
\hline${ }^{1} 1$ & 1 & 28 & 49 & 826,965 & 81.6 & 34.6 \\
\hline 1 & 2 & 27 & 48 & 826,965 & 79.3 & 34.6 \\
\hline 1 & 3 & 26 & 48 & 826,965 & 77.6 & 34.6 \\
\hline 1 & 4 & 25 & 47 & 826,965 & 75.2 & 34.6 \\
\hline 1 & 5 & 24 & 47 & 826,965 & 73.5 & 34.6 \\
\hline 1 & 6 & 23 & 46 & 826,965 & 71.2 & 34.6 \\
\hline 1 & 7 & 22 & 46 & 826,965 & 69.5 & 34.6 \\
\hline 1 & 8 & 21 & 46 & 826,965 & 67.8 & 34.6 \\
\hline 1 & 9 & 20 & 45 & 826,965 & 65.5 & 34.6 \\
\hline 1 & 10 & 20 & 44 & 826,965 & 63.8 & 34.6 \\
\hline 1 & 11 & 21 & 43 & 826,965 & 61.4 & 34.6 \\
\hline 1 & 12 & 21 & 42 & 826,965 & 59.8 & 34.6 \\
\hline 1 & 13 & 21 & 41 & 826,965 & 58.1 & 34.6 \\
\hline 1 & 14 & 21 & 40 & 826,965 & 56.4 & 34.6 \\
\hline 1 & 15 & 21 & 39 & 826,965 & 54.7 & 34.6 \\
\hline${ }^{2} 2$ & 1 & 22 & 38 & 0 & 52.4 & 0.0 \\
\hline 3 & 1 & 22 & 38 & 826,965 & 52.4 & 34.6 \\
\hline 3 & 2 & 22 & 37 & 826,965 & 50.7 & 34.6 \\
\hline 3 & 3 & 21 & 36 & 826,965 & 48.3 & 34.6 \\
\hline 3 & 4 & 21 & 35 & 826,965 & 46.7 & 34.6 \\
\hline 3 & 5 & 20 & 35 & 826,965 & 45.0 & 34.6 \\
\hline 3 & 6 & 20 & 34 & 826,965 & 43.3 & 34.6 \\
\hline 3 & 7 & 21 & 33 & 826,965 & 41.0 & 34.6 \\
\hline 3 & 8 & 21 & 32 & 826,965 & 39.3 & 34.6 \\
\hline 3 & 9 & 20 & 31 & 826,965 & 36.9 & 34.6 \\
\hline 3 & 10 & 19 & 30 & 334,610 & 34.6 & 14.0 \\
\hline 3 & 11 & 18 & 29 & 334,610 & 32.2 & 14.0 \\
\hline 3 & 12 & 18 & 28 & 334,610 & 30.5 & 14.0 \\
\hline 3 & 13 & 18 & 27 & 334,610 & 28.8 & 14.0 \\
\hline 3 & 14 & 18 & 26 & 334,610 & 27.2 & 14.0 \\
\hline 3 & 15 & 18 & 25 & 334,610 & 25.5 & 14.0 \\
\hline 3 & 16 & 18 & 24 & 334,610 & 23.8 & 14.0 \\
\hline 3 & 17 & 18 & 23 & 334,610 & 22.2 & 14.0 \\
\hline 3 & 18 & 18 & 22 & 334,610 & 20.5 & 14.0 \\
\hline 3 & 19 & 18 & 21 & 334,610 & 18.8 & 14.0 \\
\hline 3 & 20 & 18 & 20 & 334,610 & 17.1 & 14.0 \\
\hline 3 & 21 & 18 & 19 & 334,610 & 15.5 & 14.0 \\
\hline 3 & 22 & 18 & 18 & 334,610 & 13.8 & 14.0 \\
\hline 3 & 23 & 18 & 17 & 334,610 & 12.1 & 14.0 \\
\hline 3 & 24 & 18 & 16 & 334,610 & 10.4 & 14.0 \\
\hline 3 & 25 & 17 & 15 & 14.3 & 8.1 & 0.1 \\
\hline 3 & 26 & 16 & 14 & 14.3 & 5.7 & .1 \\
\hline 3 & 27 & 15 & 13 & 14.3 & 3.3 & .1 \\
\hline 3 & 28 & 15 & 12 & 14.3 & 2.2 & .1 \\
\hline 3 & 29 & 15 & 11 & 14.3 & 1.7 & .1 \\
\hline 3 & 30 & 15 & 10 & 14.3 & 1.3 & .1 \\
\hline 3 & 31 & 15 & 9 & 14.3 & 1.0 & .1 \\
\hline
\end{tabular}

${ }^{1}$ Cell at which discharge of Santa Ynez River at the Narrows is introduced.

${ }^{2}$ Cell at which outfall discharge from the city of Lompoc sewage-treatment facility is introduced. 
Discharge of the Santa Ynez River is highly seasonal, with peak discharge generally occurring in winter or spring. This seasonality is simulated in the model by dividing each calendar year into a wet period and a dry period of varying duration based on examination of the daily discharge hydrograph of the Santa Ynez River at the Narrows near Lompoc (11133000) or Santa Ynez River near Lompoc (11133500) (see fig. 5 for location). The total streamflow for each period was divided by the number of days in the period to compute an average discharge for each period (table 6). For years when discharge was uniform throughout the year, the year was divided into two equal periods.

The average discharge for each period is specified for the farthest upstream stream reach of the model (model cell row 28, column 49). Measured discharge from the Lompoc Regional Wastewater Treatment Plant is specified for the first stream reach of the second stream segment (model cell row 22 , column 38). Stormwater runoff from urbanized and agricultural areas downstream from the Narrows was not included in the stream-routing package. Although this runoff may be significant, determining the quantity of this discharge was beyond the scope of this study. Discharge from subsurface agricultural drains also was not included in the stream-routing package. The quantity of drain discharge was simulated by the model to averages 35 acre-ft/yr for 1941-88 (table 15, presented in the "Model Results" section) and is not an important source of stream discharge.

The stream-routing package calculates the discharge passing through each subsequent downstream reach of the stream by determining discharge contributed to the reach from the reach immediately upstream and adding or subtracting discharge to or from the underlying aquifer and discharge from tributaries (Prudic, 1988). Discharge to the aquifer from a stream segment is not permitted to exceed the discharge passing through that segment.

\section{Simulated Recharge}

Recharge to the Lompoc area includes (1) seepage loss from the Santa Ynez River and from streams entering the southern plain, (2) infiltration of rainfall, and (3) infiltration of irrigation return flows. The simulation of seepage loss from the Santa Ynez River was described in the preceding section.

\section{Seepage Loss along the Southern Streams}

Recharge from streams entering the southern margin of the plain (streams in San Miguelito, Lompoc, Sloans, and La Salle Canyons) was estimated from the daily discharge at San Miguelito Canyon and the maximum seepage loss rate through unlined reaches of their channels where they cross unconsolidated deposits. A complete and continuous daily discharge record for the entire modeled time period is not available for any of these southern streams. However, daily discharge data for a period of more than 16 years are available for San Miguelito Canyon (station number 11134800). Estimates of daily discharge for more than 30 years were made on the basis of regression analysis for Salsipuedes Creek near Lompoc (11132500) (daily discharge at San Miguelito Canyon is equal to 0.0856 times the daily discharge at Salsipuedes Creek; correlation coefficient of 0.913). Estimates for 90 days of the missing record were made on the basis of regression analysis of Santa Ynez River near Lompoc (11133500) (daily discharge at San Miguelito Canyon is equal to 0.00504 times the daily discharge at the Santa Ynez River; correlation coefficient of 0.584).

The discharge of each of the southern streams is assumed to be proportional to its upstream drainage area. The upstream drainage area of San Miguelito Canyon at the gage is $11.6 \mathrm{mi}^{2}$ and the upstream drainage area of San Miguelito Canyon above the point at which the streambed is lined is $10.8 \mathrm{mi}^{2}$. The daily discharge for San Miguelito Canyon above the point at which the streambed is lined, and for Lompoc, Sloans, and La Salle Canyons was estimated by multiplying the estimated or gaged daily discharge at San Miguelito Canyon by the ratio of upstream drainage area of the canyon being estimated (table 7) to the drainage area of San Miguelito Canyon above the gage (10.8/11.6 or $0.93,5.18 / 11.6$ or $0.45,4.45 / 11.6$ or 0.38 , and $2.87 / 11.6$ or 0.25 , respectively). 
Table 6. Discharge of the Santa Ynez River and the city of Lompoc sewage-treatment facility used in streamflow-routing package

[ft $\mathrm{ft}^{3} / \mathrm{s}$, cubic foot per second]

\begin{tabular}{|c|c|c|c|c|c|}
\hline \multirow[b]{2}{*}{$\begin{array}{c}\text { Stress period } \\
\text { (decimal years) }\end{array}$} & \multicolumn{2}{|c|}{ Discharge } & \multirow[b]{2}{*}{$\begin{array}{c}\text { Date } \\
\text { (decimal years) }\end{array}$} & \multicolumn{2}{|c|}{ Discharge } \\
\hline & $\begin{array}{l}\text { Santa Ynez } \\
\text { River } \\
\left(\mathrm{ft}^{3} / \mathrm{s}\right)\end{array}$ & $\begin{array}{c}\text { Sewage } \\
\text { treatment } \\
\left(\mathrm{ft}^{3} / \mathrm{s}\right)\end{array}$ & & $\begin{array}{c}\text { Santa Ynez } \\
\text { River } \\
\left(\mathrm{ft}^{3} / \mathrm{s}\right)\end{array}$ & $\begin{array}{l}\text { Sewage } \\
\text { treatment } \\
\left(\mathrm{ft}^{3} / \mathrm{s}\right)\end{array}$ \\
\hline 1941.00 & $1,360.1$ & 0.52 & 1965.00 & 8.2 & 2.47 \\
\hline 1941.65 & 78.1 & 0.52 & 1965.83 & 118.9 & 2.47 \\
\hline 1942.00 & 118.4 & 0.52 & 1966.00 & 81.6 & 3.18 \\
\hline 1942.57 & 9.6 & 0.52 & 1966.22 & 10.8 & 3.18 \\
\hline 1943.00 & 719.1 & 0.52 & 1967.00 & 428.3 & 8.38 \\
\hline 1943.43 & 12.3 & 0.52 & 1967.50 & 3.4 & 8.38 \\
\hline 1944.00 & 355.3 & 0.52 & 1968.00 & 22.1 & 3.33 \\
\hline 1944.45 & 12.7 & 0.52 & 1968.31 & 0.9 & 3.33 \\
\hline 1945.00 & 172.7 & 0.81 & 1969.00 & $1,680.2$ & 8.38 \\
\hline 1945.37 & 15.3 & 0.81 & 1969.50 & 10.3 & 8.38 \\
\hline 1946.00 & 118.2 & 1.09 & 1970.00 & 27.3 & 2.76 \\
\hline 1946.38 & 14.2 & 1.09 & 1970.29 & 4.1 & 2.76 \\
\hline 1947.00 & 55.3 & 1.38 & 1971.00 & 27.5 & 3.25 \\
\hline 1947.15 & 3.4 & 1.38 & 1971.26 & 2.1 & 3.25 \\
\hline 1948.00 & 0.1 & 1.38 & 1972.00 & 17.9 & 3.25 \\
\hline 1948.96 & 5.2 & 1.38 & 1972.19 & 0.2 & 3.25 \\
\hline 1949.00 & 9.1 & 1.38 & 1973.00 & 258.0 & 8.38 \\
\hline 1949.29 & 0.0 & 1.38 & 1973.43 & 2.4 & 8.38 \\
\hline 1950.00 & 0.0 & 1.38 & 1974.00 & 81.2 & 3.24 \\
\hline 1950.50 & 0.0 & 1.38 & 1974.33 & 6.6 & 3.24 \\
\hline 1951.00 & 0.0 & 1.38 & 1975.00 & 189.1 & 3.24 \\
\hline 1951.50 & 0.6 & 1.38 & 1975.43 & 1.6 & 3.24 \\
\hline 1952.00 & 704.5 & 8.38 & 1976.00 & 20.1 & 3.00 \\
\hline 1952.51 & 29.6 & 8.38 & 1976.23 & 0.6 & 3.00 \\
\hline 1953.00 & 53.8 & 1.38 & 1977.00 & 0.7 & 3.46 \\
\hline 1953.25 & 0.8 & 1.38 & 1977.50 & 0.0 & 3.46 \\
\hline 1954.00 & 18.1 & 1.38 & 1978.00 & $1,118.8$ & 8.38 \\
\hline 1954.43 & 0.0 & 1.38 & 1978.48 & 6.9 & 8.38 \\
\hline 1955.00 & 6.8 & 1.38 & 1979.00 & 233.1 & 4.19 \\
\hline 1955.29 & 22.3 & 1.38 & 1979.41 & 1.2 & 4.19 \\
\hline 1956.00 & 56.7 & 1.38 & 1980.00 & 696.1 & 4.85 \\
\hline 1956.43 & 0.2 & 1.38 & 1980.37 & 3.7 & 4.85 \\
\hline 1957.00 & 5.9 & 1.38 & 1981.00 & 83.3 & 4.88 \\
\hline 1957.28 & 0.2 & 1.38 & 1981.32 & 1.6 & 4.88 \\
\hline 1958.00 & 388.9 & 8.38 & 1982.00 & 25.8 & 4.90 \\
\hline 1958.49 & 2.3 & 8.38 & 1982.31 & 11.4 & 4.90 \\
\hline 1959.00 & 79.4 & 1.38 & 1983.00 & $1,290.4$ & 8.38 \\
\hline 1959.28 & 0.6 & 1.38 & 1983.53 & 67.8 & 8.38 \\
\hline 1960.00 & 5.3 & 1.38 & 1984.00 & 98.6 & 5.15 \\
\hline 1960.36 & 0.6 & 1.38 & 1984.15 & 4.6 & 5.15 \\
\hline 1961.00 & 0.1 & 1.38 & 1985.00 & 12.2 & 5.39 \\
\hline 1961.85 & 4.5 & 1.38 & 1985.13 & 1.6 & 5.39 \\
\hline 1962.00 & 296.3 & 8.38 & 1986.00 & 119.2 & 5.51 \\
\hline 1962.41 & 1.2 & 8.38 & 1986.32 & 6.4 & 5.51 \\
\hline 1963.00 & 30.2 & 1.80 & 1987.00 & 25.0 & 5.64 \\
\hline 1963.42 & 1.1 & 1.80 & 1987.23 & 1.1 & 5.64 \\
\hline 1964.00 & 0.0 & 2.05 & 1988.00 & 2.3 & 5.44 \\
\hline 1964.50 & 0.0 & 2.05 & 1988.50 & 0.5 & 5.44 \\
\hline
\end{tabular}


Table 7. Characteristics of annual seepage from southern streams

$\left[\mathrm{mi}^{2}\right.$, square mile; ft, foot; $\mathrm{ft}^{3} / \mathrm{d}$, cubic foot per day; acre-ft, acre-foot]

\begin{tabular}{|c|c|c|c|c|c|}
\hline \multicolumn{6}{|c|}{ Southern streams } \\
\hline & $\begin{array}{c}\text { San Miguelito } \\
\text { Canyon }\end{array}$ & $\begin{array}{l}\text { Sloans } \\
\text { Canyon }\end{array}$ & $\begin{array}{l}\text { La Salle } \\
\text { Canyon }\end{array}$ & $\begin{array}{l}\text { Lompoc } \\
\text { Canyon } \\
\end{array}$ & Total \\
\hline Upstream drainage area $\left(\mathrm{mi}^{2}\right)$ & 10.8 & 5.18 & 4.45 & 2.87 & 23.30 \\
\hline Length of unlined stream (ft) & 8,511 & 18,064 & 5,033 & 4,643 & 36,251 \\
\hline Maximum seepage loss $\left(\mathrm{ft}^{3} / \mathrm{d}\right)$ & 280,900 & 596,100 & 166,100 & 153,200 & $1,196,300$ \\
\hline \multicolumn{6}{|c|}{ Annual seepage from southern streams (acre-ft) } \\
\hline 1941 & 2,641 & 1,145 & 775 & 1,496 & 6,057 \\
\hline 1942 & 527 & 228 & 155 & 299 & 1,209 \\
\hline 1943 & 742 & 322 & 219 & 420 & 1,703 \\
\hline 1944 & 597 & 259 & 175 & 338 & 1,369 \\
\hline 1945 & 157 & 68 & 46 & 89 & 360 \\
\hline 1946 & 142 & 61 & 42 & 80 & 325 \\
\hline 1947 & 40 & 17 & 12 & 23 & 92 \\
\hline 1948 & 41 & 18 & 12 & 23 & 94 \\
\hline 1949 & 123 & 53 & 36 & 70 & 282 \\
\hline 1950 & 84 & 37 & 25 & 48 & 194 \\
\hline 1951 & 35 & 15 & 10 & 20 & 80 \\
\hline 1952 & 918 & 398 & 270 & 520 & 2,106 \\
\hline 1953 & 165 & 71 & 48 & 93 & 377 \\
\hline 1954 & 176 & 76 & 52 & 100 & 404 \\
\hline 1955 & 294 & 128 & 86 & 167 & 675 \\
\hline 1956 & 410 & 178 & 120 & 232 & 940 \\
\hline 1957 & 92 & 40 & 27 & 52 & 211 \\
\hline 1958 & 1,328 & 576 & 390 & 752 & 3,046 \\
\hline 1959 & 172 & 74 & 50 & 97 & 393 \\
\hline 1960 & 128 & 56 & 38 & 73 & 295 \\
\hline 1961 & 75 & 32 & 22 & 42 & 171 \\
\hline 1962 & 956 & 414 & 281 & 542 & 2,193 \\
\hline 1953 & 366 & 159 & 108 & 208 & 841 \\
\hline 1964 & 61 & 26 & 18 & 34 & 139 \\
\hline 1965 & 492 & 213 & 145 & 279 & 1,129 \\
\hline 1966 & 346 & 150 & 102 & 196 & 794 \\
\hline 1967 & 318 & 138 & 94 & 180 & 730 \\
\hline 1968 & 44 & 19 & 13 & 25 & 101 \\
\hline 1969 & 1,180 & 511 & 345 & 668 & 2,704 \\
\hline 1970 & 144 & 62 & 42 & 82 & 330 \\
\hline 1971 & 176 & 76 & 52 & 100 & 404 \\
\hline 1972 & 92 & 40 & 27 & 52 & 211 \\
\hline 1973 & 1,202 & 521 & 353 & 681 & 2,757 \\
\hline 1974 & 714 & 309 & 210 & 404 & 1,637 \\
\hline 1975 & 1,050 & 455 & 308 & 594 & 2,407 \\
\hline 1976 & 277 & 120 & 81 & 157 & 635 \\
\hline 1977 & 108 & 47 & 32 & 61 & 248 \\
\hline 1978 & 2,389 & 1,036 & 701 & 1,353 & 5,479 \\
\hline 1979 & 941 & 408 & 276 & 533 & 2,158 \\
\hline 1980 & 1,222 & 530 & 359 & 692 & 2,803 \\
\hline 1981 & 689 & 299 & 202 & 390 & 1,580 \\
\hline 1982 & 621 & 270 & 182 & 352 & 1,425 \\
\hline 1983 & 3,993 & 1,731 & 1,172 & 2,262 & 9,158 \\
\hline 1984 & 740 & 321 & 217 & 419 & 1,697 \\
\hline 1985 & 415 & 180 & 122 & 211 & 928 \\
\hline 1986 & 786 & 341 & 231 & 445 & 1,803 \\
\hline 1987 & 184 & 80 & 54 & 105 & 423 \\
\hline 1988 & 240 & 103 & 70 & 135 & 548 \\
\hline Average & 597 & 259 & 175 & 337 & 1,368 \\
\hline
\end{tabular}


A maximum seepage loss of $33\left(\mathrm{ft}^{3} / \mathrm{d}\right) / \mathrm{ft}$ of channel length is assumed for the southern streams on the basis of seepage-loss measurements made on Mission Creek in the Santa Barbara area (McFadden and others, 1991), which has similar stream characteristics. The product of the length of the unlined portion of the channel times the maximum seepage loss rate of $33\left(\mathrm{ft}^{3} / \mathrm{d}\right) / \mathrm{ft}$ of channel length yields the maximum daily seepage-loss recharge from each of the southern streams (table 7). For days when the discharge is less than the maximum seepage loss, the entire estimated stream discharge is assumed to be stream recharge. For days when the discharge is greater than the maximum seepage loss, the excess stream discharge is assumed to runoff into the Santa Ynez River. As stated previously, this stream discharge was not included in the stream-routing package used to simulate the interaction of the Santa Ynez River with the aquifer system. Seepage for each day is summed to determine total seepage loss for each year (table 7; fig. 15). Total seepage loss recharge from the southern streams is given in table 7. The estimated annual recharge from each stream is distributed evenly into the active model cells for each stream (fig. 16).

\section{Rainfall Infiltration}

Recharge from rainfall infiltration was simulated by areal recharge in layer 1 using four different rates of recharge (fig. 17). The recharge rate from rainfall in the Lompoc upland and terrace was assumed to be $0.125 \mathrm{ft} / \mathrm{yr}(1.5 \mathrm{in} / \mathrm{yr})$ on the basis of watershed studies completed by Santa Barbara County (Jon Ahlroth, Santa Barbara County Water Agency, written commun., 1995). Recharge from rainfall infiltration in the Lompoc upland and terrace is assumed to be constant throughout the model simulation. The use of a constant value is based on other studies (Bouwer, 1980, p.17; Hillel, 1971, p. 137) that suggest that the downward movement of water eventually reaches a steady state or nearly constant rate in areas where a large unsaturated zone exists.

The recharge rates simulated on the Lompoc plain were based on a detailed study by Blaney and others (1963) and on model calibration. Blaney and others (1963) estimated that during the period 1957-62 an annual average of 44 percent of the total applied water (including rainfall) on the Lompoc plain returned to the ground-water system. The annual rainfall infiltration on the Lompoc plain was assumed to be equal to 44 percent of the annual rainfall at Lompoc (table 8). During model calibration, this value was reduced to 15 percent of the annual rainfall on the western and central parts of the plain (fig. 17). This area of the Lompoc plain has a high percentage of fine-grained material in the shallow zone that limits rainfall infiltration. During wetter-than-normal years much of the rainfall is rejected in the western and central plains and runs off into manmade and natural drainages that discharge to the Santa Ynez River (Virgil Phelps, former director, Santa Ynez Water Conservation District, oral commun., 1992). In reality, the transition in recharge rates from 44 to 15 percent is probably not as abrupt as simulated; however, to simplify the model only two values were used.

The area of the plain occupied by the city of Lompoc was assigned a reduced rainfall infiltration rate of 10 percent of the average annual rainfall. Urbanization has reduced the quantity of recharge from rainfall infiltration by capturing much of the runoff in storm drains and canals that discharge to the Santa Ynez River. Storm water runoff from the urbanized area was not included in the streamrouting package used to simulate the interaction of the Santa Ynez River with the aquifer system, because the quantity is believed to be small compared to the total flow in the river. Total simulated recharge from rainfall infiltration for each area is given in table 8 .

\section{Irrigation-Return Flow}

Estimates of annual recharge from irrigation-return in the Lompoc plain range from 15 to about 44 percent of the annual agricultural pumpage (Upson and Thomasson, 1951; Blaney and others, 1963). The lower recharge estimate reflects, in part, higher irrigation efficiencies. For example, in many areas of the central and western plains, poor drainage has forced farmers to apply more efficient irrigation methods, such as installation of tile drains and field leveling. Therefore, for the central and western 


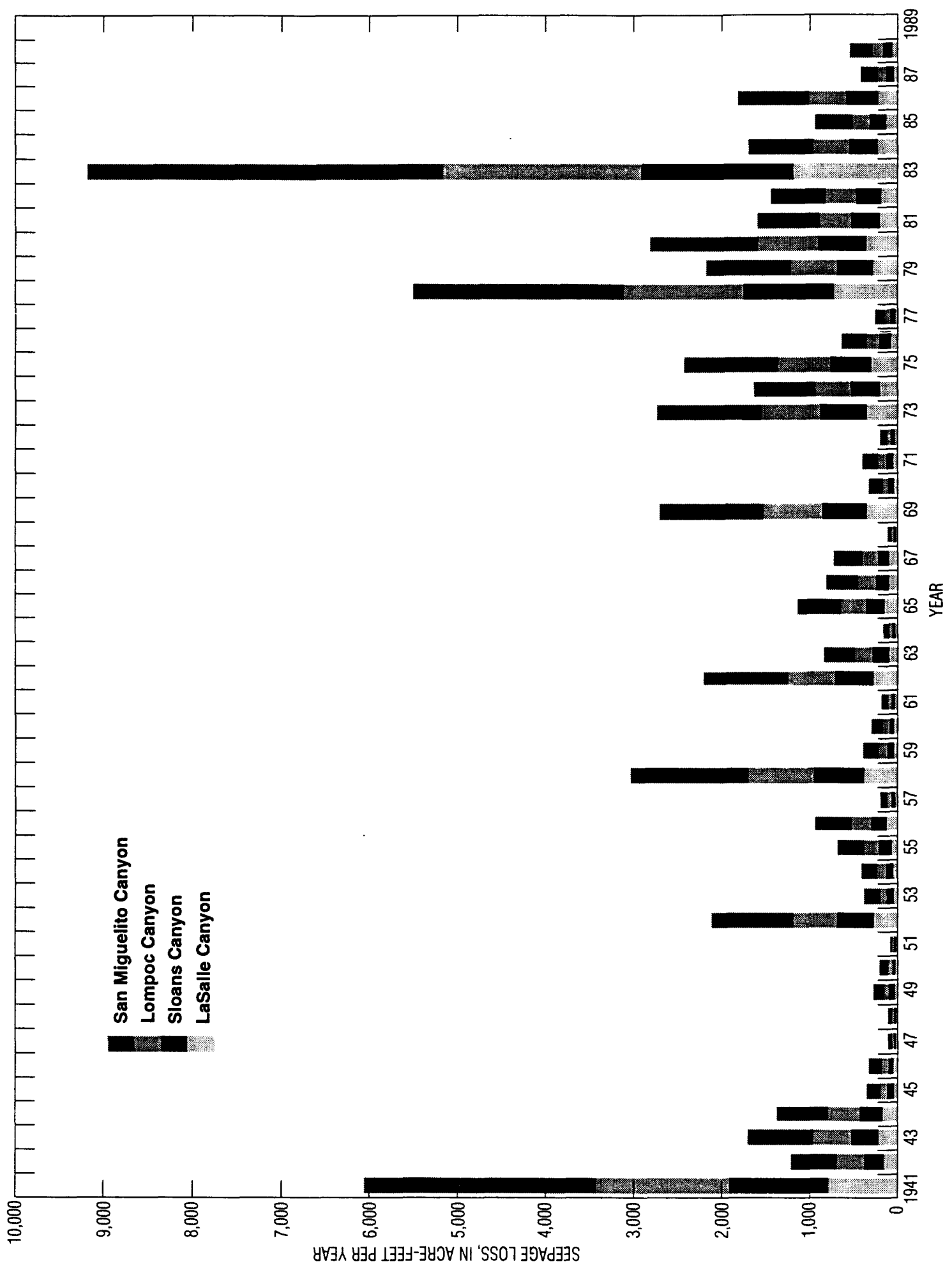




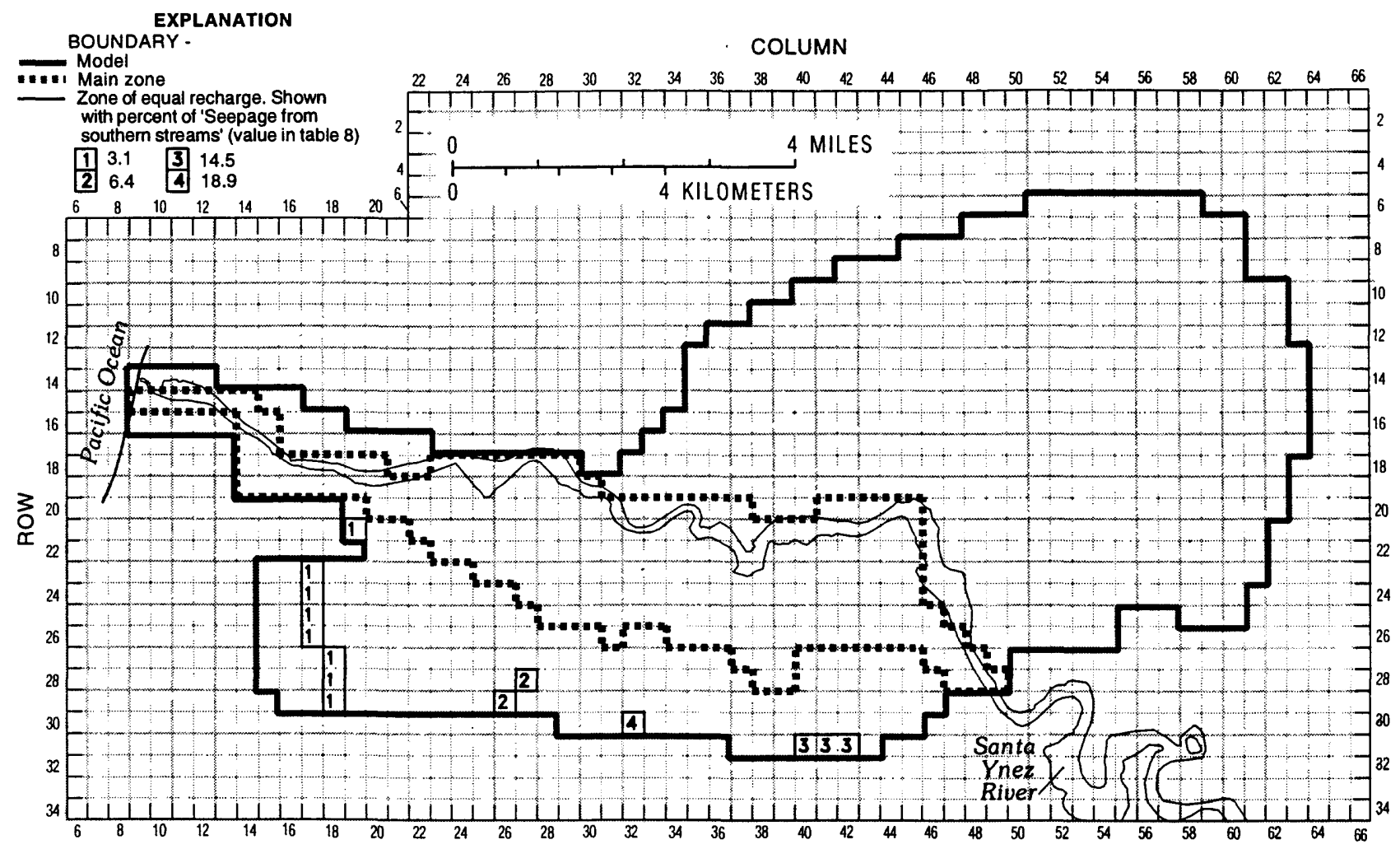

Figure 16. Areal distribution of seepage from streams entering the southern plain in the Lompoc area.

EXPLANATION

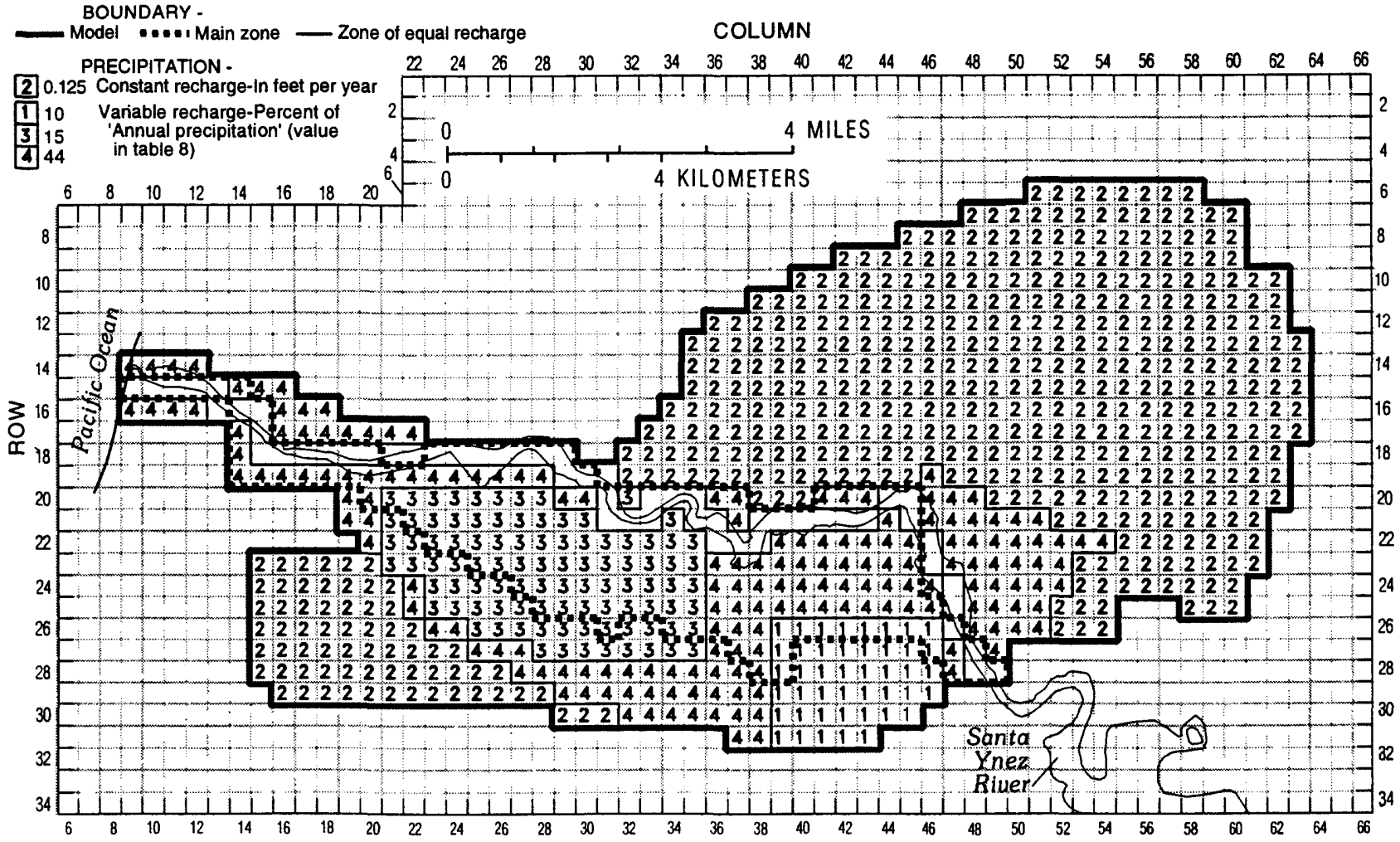

Figure 17. Areal distribution of recharge from rainfall infiltration in the Lompoc area. 
Table 8. Annual recharge from precipitation, irrigation return flow, and seepage from southern streams simulated in the ground-water flow model, 1941-88

[All values in acre-feet per year except where noted]

\begin{tabular}{|c|c|c|c|c|c|c|c|}
\hline \multirow[b]{2}{*}{ Year } & \multicolumn{4}{|c|}{ Recharge from precipitation } & \multirow{2}{*}{$\begin{array}{l}\text { Lompoc plain } \\
\text { irrigation return } \\
\text { flow }\end{array}$} & \multirow{2}{*}{$\begin{array}{l}\text { Seepage from } \\
\text { southern } \\
\text { streams }\end{array}$} & \multirow[b]{2}{*}{ Total recharge } \\
\hline & (inches) & Lompoc plain & Uplands & Lompoc terrace & & & \\
\hline 1941 & 41 & 13,015 & 2,016 & 333 & 1,989 & 6,057 & 23,410 \\
\hline 1942 & 9 & 2,924 & 2,016 & 333 & 2,610 & 1,209 & 9,092 \\
\hline 1943 & 14 & 4,515 & 2,016 & 333 & 2,898 & 1,703 & 11,465 \\
\hline 1944 & 15 & 4,645 & 2,016 & 333 & 3,689 & 1,369 & 12,052 \\
\hline 1945 & 12 & 3,772 & 2,016 & 333 & 4,814 & 360 & 11,295 \\
\hline 1946 & 12 & 3,925 & 2,016 & 333 & 4,621 & 10,895 & 11,220 \\
\hline 1947 & 4 & 1,317 & 2,016 & 333 & 7,451 & 92 & 11,209 \\
\hline 1948 & 12 & 3,762 & 2,016 & 333 & 4,617 & 94 & 10,822 \\
\hline 1949 & 13 & 4,285 & 2,016 & 333 & 5,685 & 282 & 12,601 \\
\hline 1950 & 9 & 2,924 & 2,016 & 333 & 7,718 & 194 & 13,185 \\
\hline 1951 & 11 & 3,498 & 2,016 & 333 & 4,860 & 80 & 10,787 \\
\hline 1952 & 25 & 8,063 & 2,016 & 333 & 4,190 & 2,106 & 16,708 \\
\hline 1953 & 6 & 2,060 & 2,016 & 333 & 4,258 & 377 & 9,044 \\
\hline 1954 & 12 & 3,836 & 2,016 & 333 & 4,352 & 10,537 & 10,941 \\
\hline 1955 & 18 & 5,749 & 2,016 & 333 & 5,666 & 675 & 14,439 \\
\hline 1956 & 6 & 2,047 & 2,016 & 333 & 6,172 & 940 & 11,508 \\
\hline 1957 & 13 & 4,205 & 2,016 & 333 & 8,739 & 211 & 15,504 \\
\hline 1958 & 20 & 6,240 & 2,016 & 333 & 5,834 & 3,046 & 17,469 \\
\hline 1959 & 7 & 2,331 & 2,016 & 333 & 7,174 & 393 & 12,247 \\
\hline 1960 & 14 & 4,371 & 2,016 & 333 & 7,122 & 295 & 14,137 \\
\hline 1961 & 7 & 2,363 & 2,016 & 333 & 6,391 & 171 & 11,274 \\
\hline 1962 & 15 & 4,936 & 2,016 & 333 & 6,160 & 2,193 & 15,638 \\
\hline 1963 & 16 & 5,229 & 2,016 & 333 & 4,541 & 841 & 12,960 \\
\hline 1964 & 12 & 3,963 & 2,016 & 333 & 4,541 & 139 & 10,992 \\
\hline 1965 & 17 & 5,487 & 2,016 & 333 & 4,541 & 1,129 & 13,506 \\
\hline 1966 & 7 & 2,302 & 2,016 & 333 & 3,697 & 794 & 9,142 \\
\hline 1967 & 14 & 4,499 & 2,016 & 333 & 3,506 & 730 & 11,084 \\
\hline 1968 & 9 & 2,956 & 2,016 & 333 & 3,664 & 101 & 9,070 \\
\hline 1969 & 22 & 6,877 & 2,016 & 333 & 3,654 & 2,704 & 15,584 \\
\hline 1970 & 14 & 4,502 & 2,016 & 333 & 3,950 & 330 & 11,131 \\
\hline 1971 & 9 & 2,924 & 2,016 & 333 & 4,269 & 404 & 9,946 \\
\hline 1972 & 7 & 2,356 & 2,016 & 333 & 4,695 & 211 & 9,611 \\
\hline 1973 & 20 & 6,307 & 2,016 & 333 & 4,985 & 2,757 & 16,398 \\
\hline 1974 & 17 & 5,462 & 2,016 & 333 & 5,149 & 1,637 & 14,597 \\
\hline 1975 & 12 & 3,781 & 2,016 & 333 & 5,313 & 2,407 & 13,850 \\
\hline 1976 & 13 & 4,164 & 2,016 & 333 & 5,430 & 635 & 12,578 \\
\hline 1977 & 10 & 3,147 & 2,016 & 333 & 5,548 & 248 & 11,292 \\
\hline 1978 & 30 & 9,501 & 2,016 & 333 & 5,666 & 5,479 & 22,995 \\
\hline 1979 & 16 & 5,238 & 2,016 & 333 & 5,783 & 2,158 & 15,528 \\
\hline 1980 & 14 & 4,435 & 2,016 & 333 & 5,901 & 2,803 & 15,488 \\
\hline 1981 & 15 & 4,696 & 2,016 & 333 & 6,019 & 1,580 & 14,644 \\
\hline 1982 & 17 & 5,417 & 2,016 & 333 & 6,137 & 1,425 & 15,328 \\
\hline 1983 & 33 & 10,413 & 2,016 & 333 & 6,254 & 9,158 & 28,174 \\
\hline 1984 & 9 & 2,940 & 2,016 & 333 & 6,372 & 1,697 & 13,358 \\
\hline 1985 & 9 & 2,921 & 2,016 & 333 & 6,490 & 928 & 12,688 \\
\hline 1986 & 16 & 5,038 & 2,016 & 333 & 6,490 & 1,803 & 15,680 \\
\hline 1987 & 15 & 4,865 & 2,016 & 333 & 6,490 & 423 & 14,127 \\
\hline 1988 & 11 & 3,520 & 2,016 & 333 & 6,490 & 548 & 12,907 \\
\hline Average & 14 & 4,536 & 2,016 & $\overline{333}$ & 5,262 & 1,368 & 13,515 \\
\hline
\end{tabular}


plains, recharge from irrigation-return flow was assumed to equal 15 percent of the annual agricultural pumpage. For the remaining areas of the plain where poor drainage is not a significant irrigation problem, recharge was assumed to equal 44 percent of the annual agricultural pumpage. As previously stated in the "Rainfall Infiltration" section, the transition in recharge rates from 44 to 15 percent is probably not as abrupt as simulated in the model. Total annual recharge from irrigation return is given in table 8 and the areal distribution is presented in figure 18. All return-flow recharge was simulated in layer 1 in the same areal location in which the pumping occurred. For example, if pumping occurred in layer 3, row 24, column 28; the return-flow recharge was simulated in layer 1, row 24, column 28.

\section{Simulated Discharge}

The primary components of ground-water discharge from the aquifer system are (1) pumpage, (2) seepage to drains, (3) seepage to the Santa Ynez River, (4) transpiration by pheatophytes along the Santa Ynez River, and (5) underflow from the upper aquifer to the Pacific Ocean. The simulation of seepage to the Santa Ynez River was discussed in the "Stream-Aquifer Relations" section of this report, and underflow from the aquifer was discussed in the "Boundary Conditions" section.

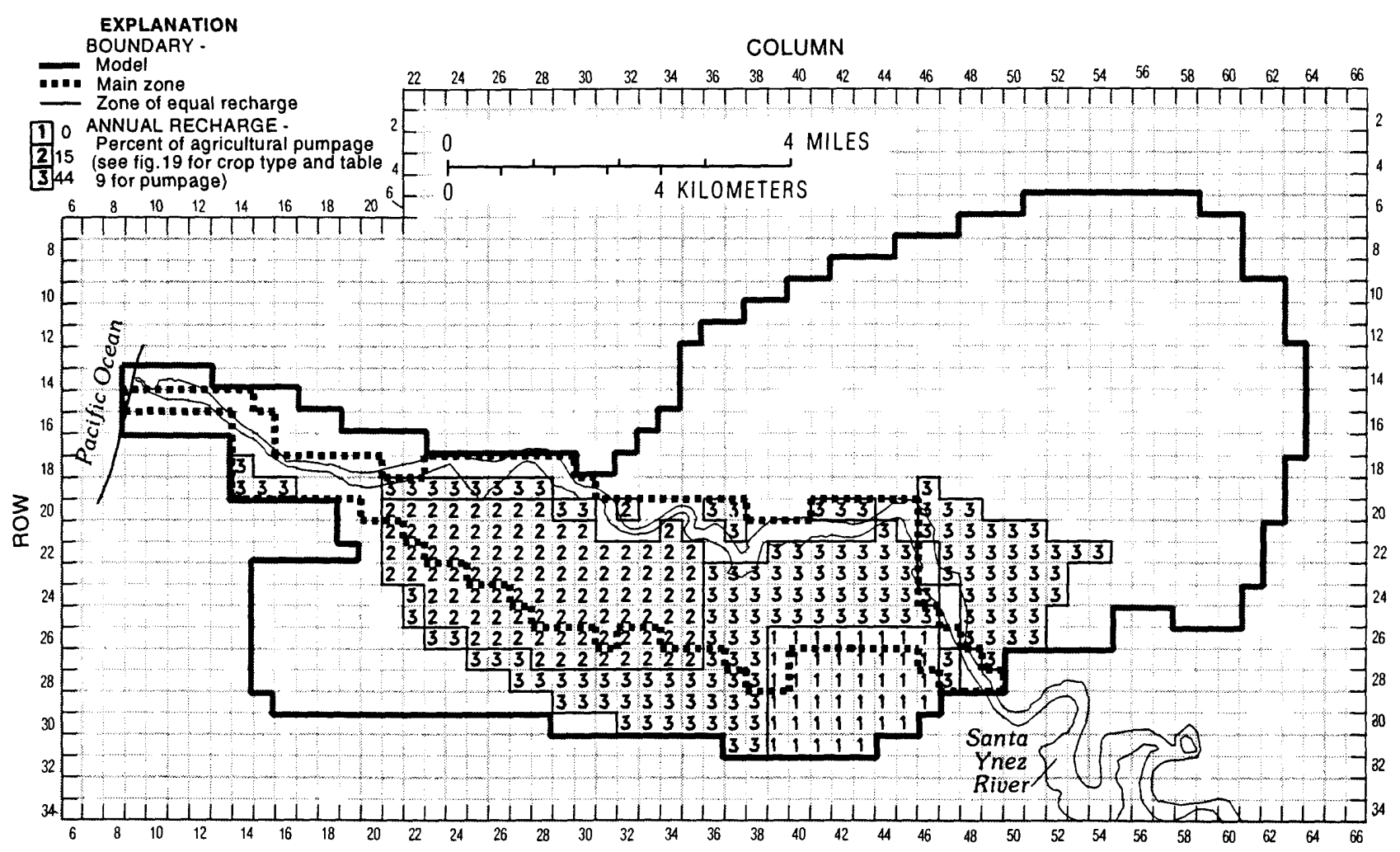

Figure 18. Areal distribution of irrigation return flow in the Lompoc area. 


\section{Pumpage}

Ground-water pumpage is the principal discharge from the aquifer system. For this report, pumpage is divided into three categories of usage: (1) agricultural-which consists of all water pumped for irrigation in the Lompoc plain, including water pumped by the U.S. Penitentiary (USP) and water pumped for irrigation at the golf course in Vandenberg Village and at the La Purisima golf course, (2) municipal - which includes water pumped by the city of Lompoc, and by the Mission Hills and Vandenberg Village water districts, and (3) military-which includes water pumped by VAFB in the plain and terrace areas. Pumpage for domestic and industrial uses that is not supplied by Municipal water sources is probably a few hundred acre-ft/yr (Miller, 1976, p.33) and is considered negligible for modeling purposes.

Annual ground-water pumpage in the Lompoc area, which was estimated in previous studies, was summarized by Bright and others (1992) for the years 1941-85. For the years 1986-88, agricultural pumpage was assumed to be the same as that estimated for 1985, and municipal and military pumpages were metered. Annual agricultural, municipal, and military pumpage (1941-88) simulated in the ground-water flow model are given in table 9.

Although annual agricultural pumpage was estimated in previous studies, the distribution of pumpage was not determined. For this study, the pumpage distribution was based on the 1985 land use (California Department of Water Resources, 1987) and on historical aerial photographs. Irrigated agriculture in the Lompoc area was separated into field or truck crops. For this study, field crops are crops that normally are single-cropped (only one crop is harvested from a field in a year), such as beans, sugar beets, grain, and ornamental flowers. The consumptive use of field crops ranges from 0.3 to 2.0 acre-ft/acre per year (Santa Ynez River Conservation District, written commun., 1995). Truck crops include vegetables such as lettuce, celery, and broccoli that are commonly multi-cropped (more than one crop is harvested from the same field in a year). The consumptive use of truck crops ranges from 2.2 to 4.0 acre-ft/acre per year (Santa Ynez River Conservation District, written commun., 1995).

Two agricultural-pumpage distributions were used in the transient calibration representing the periods 1941-69 and 1970-88 (fig. 19). In the 1941-69 distribution, the western plain consists primarily of field crops; whereas, in the 1970-88 distribution; the western plain consists primarily of truck crops. The crop distribution in the remainder of the plain is constant throughout the period. A total of 224 model cells are used to simulate agricultural pumpage, with 167 field-crop and 57 truckcrop cells in the 1941-69 period and 146 field-crop and 78 truck-crop cells in the 1970-88 period.

The irrigation pumpage assigned to each cell is determined for each year on the basis of the following rules:

(1) If total agricultural pumpage for a given year divided by the entire irrigated area ( 8,960 acres) is less than or equal to $1.0 \mathrm{ft} / \mathrm{yr}$, the same pumpage rate is assigned to both crop types.

(2) If total agricultural pumpage for a given year divided by the entire irrigated area is more than $1.0 \mathrm{ft} / \mathrm{yr}$, a rate of $1.0 \mathrm{ft} / \mathrm{yr}$ is assigned to the field-crop cells and the remaining pumpage is spread over the truck-crop cells.

a. If the pumpage rate of the truck-crop cells exceeds $3.0 \mathrm{ft} / \mathrm{yr}$, the excess pumpage is assigned to the field-crop cells.

b. If this additional pumpage results in a pumpage rate of more than $3.0 \mathrm{ft} / \mathrm{yr}$ for the fieldcrop cells , a pumpage rate of $3.0 \mathrm{ft} / \mathrm{yr}$ is assigned to the field-crop cells and the remaining pumpage is spread evenly over the truck-crop cells. 


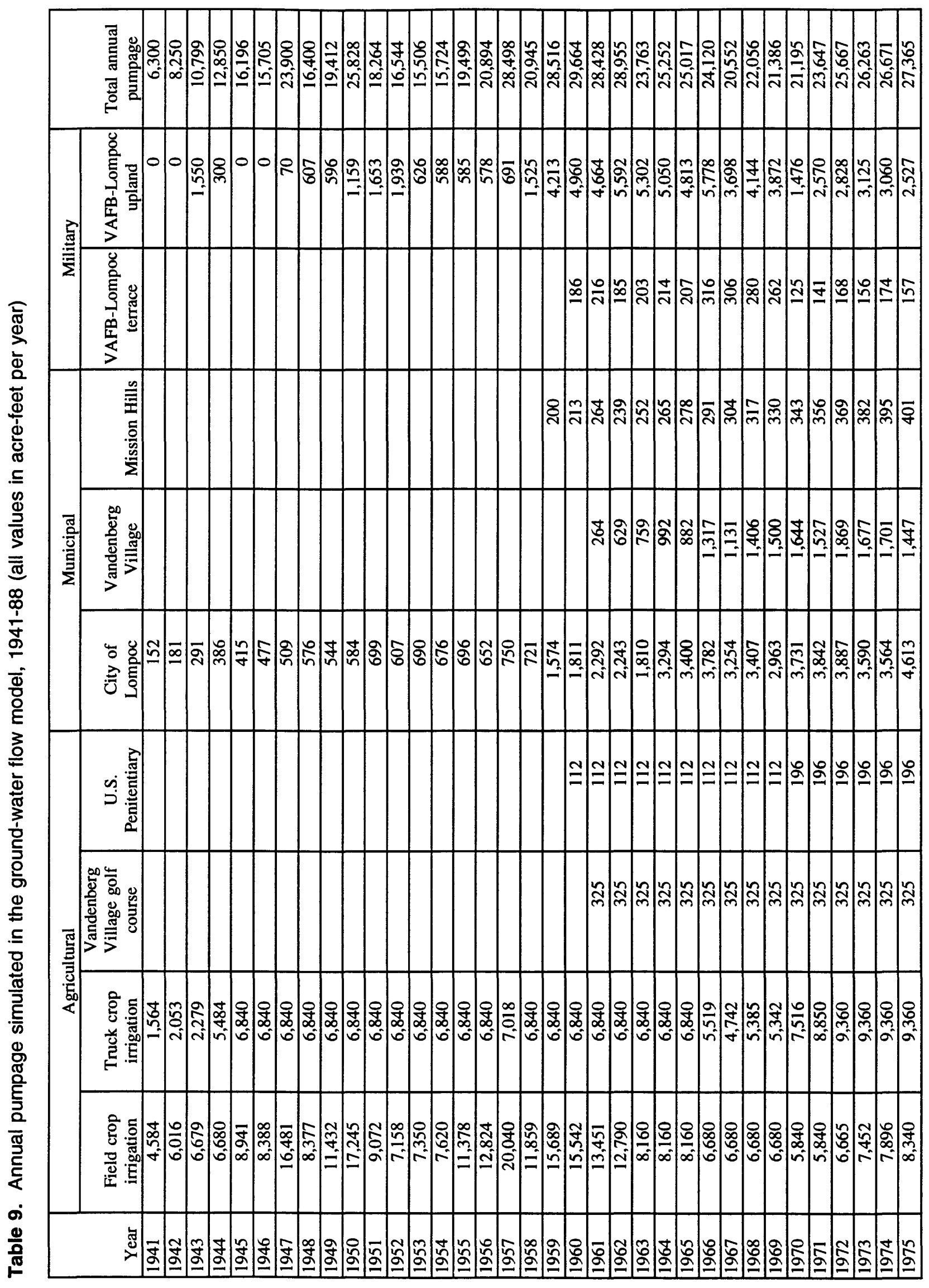




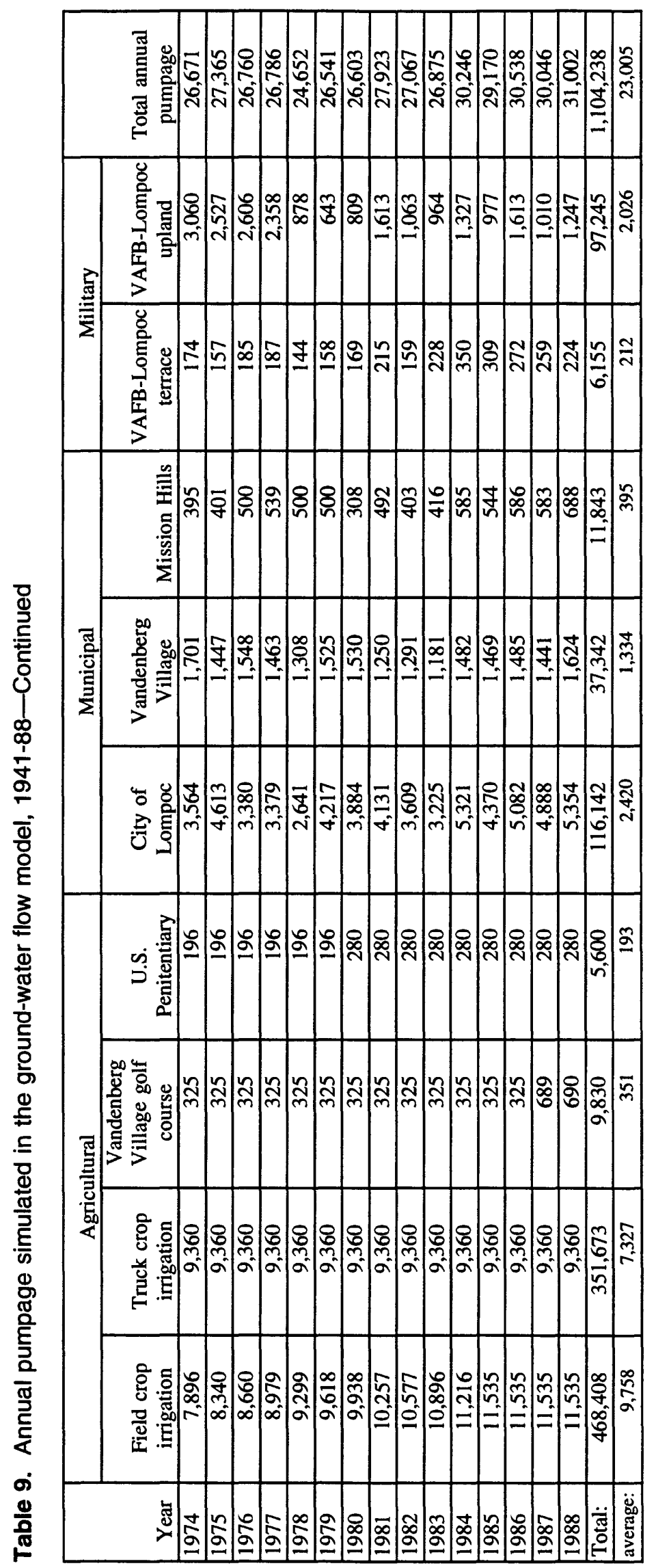



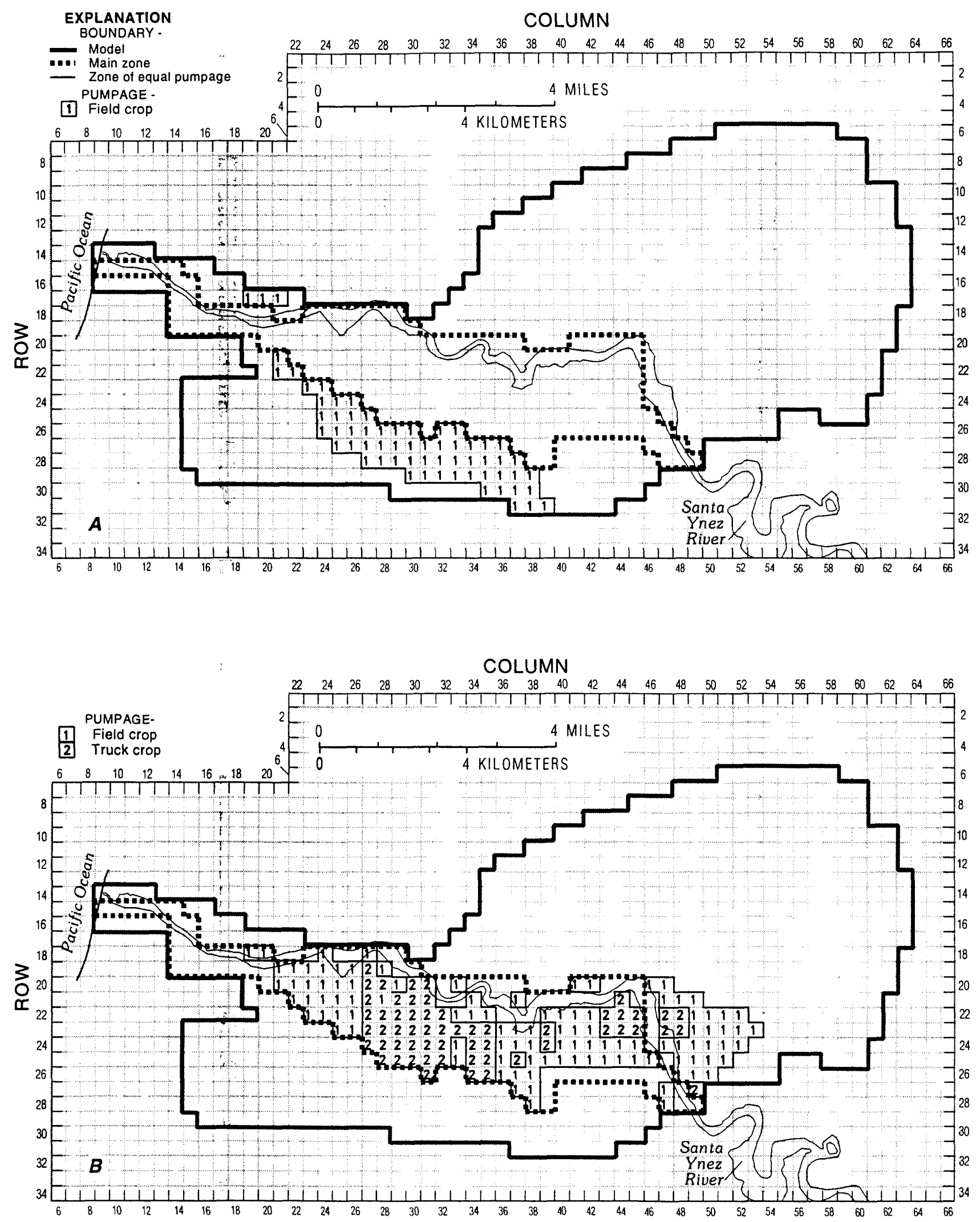

Figure 19. Areal distribution of irrigation pumpage in the Lompoc area: (A) layer 2, 1941-69; (B) layer 3, 1941-69; (C) layer 2, 1970-88; (D) layer 3, 1970-88. 


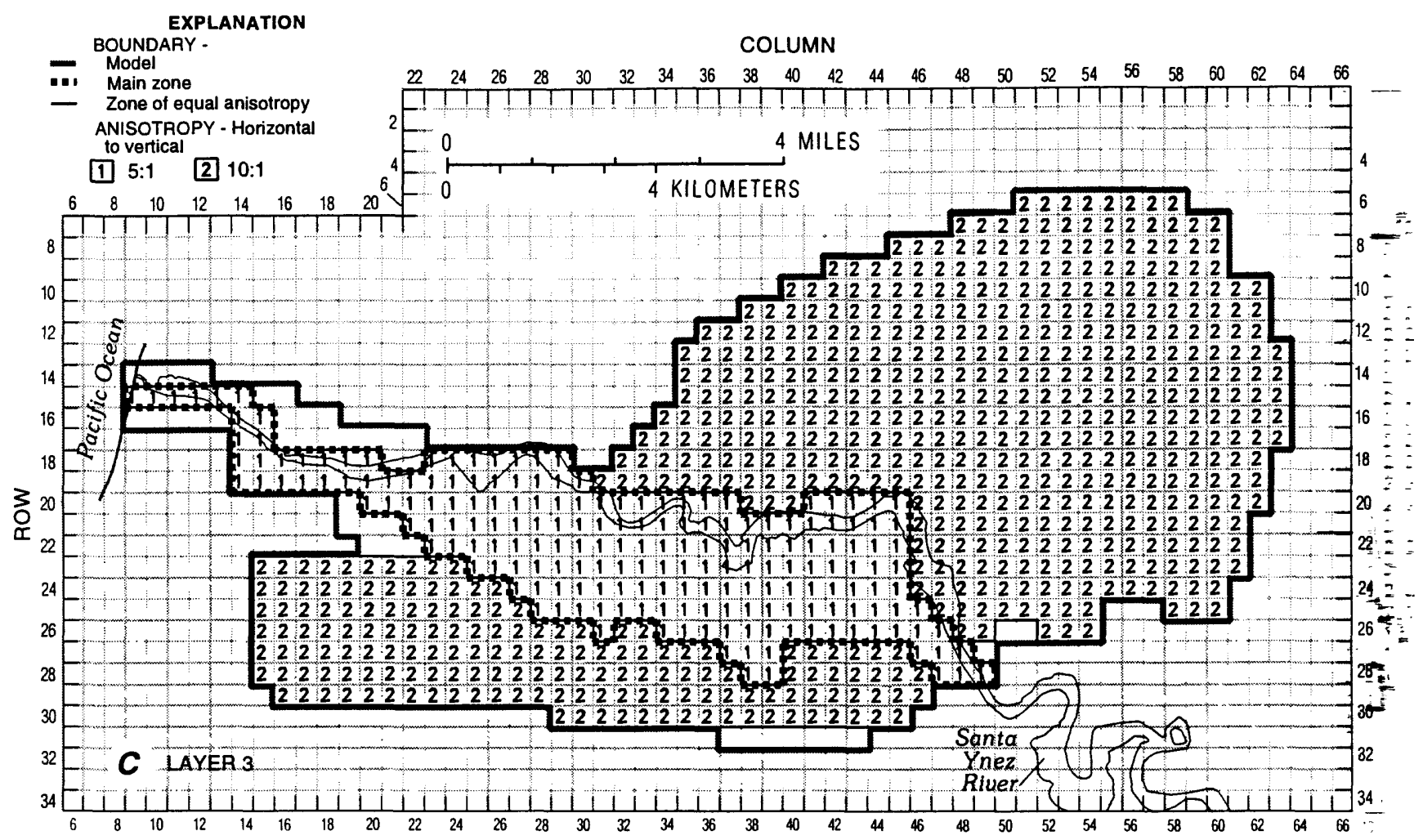

COLUMN

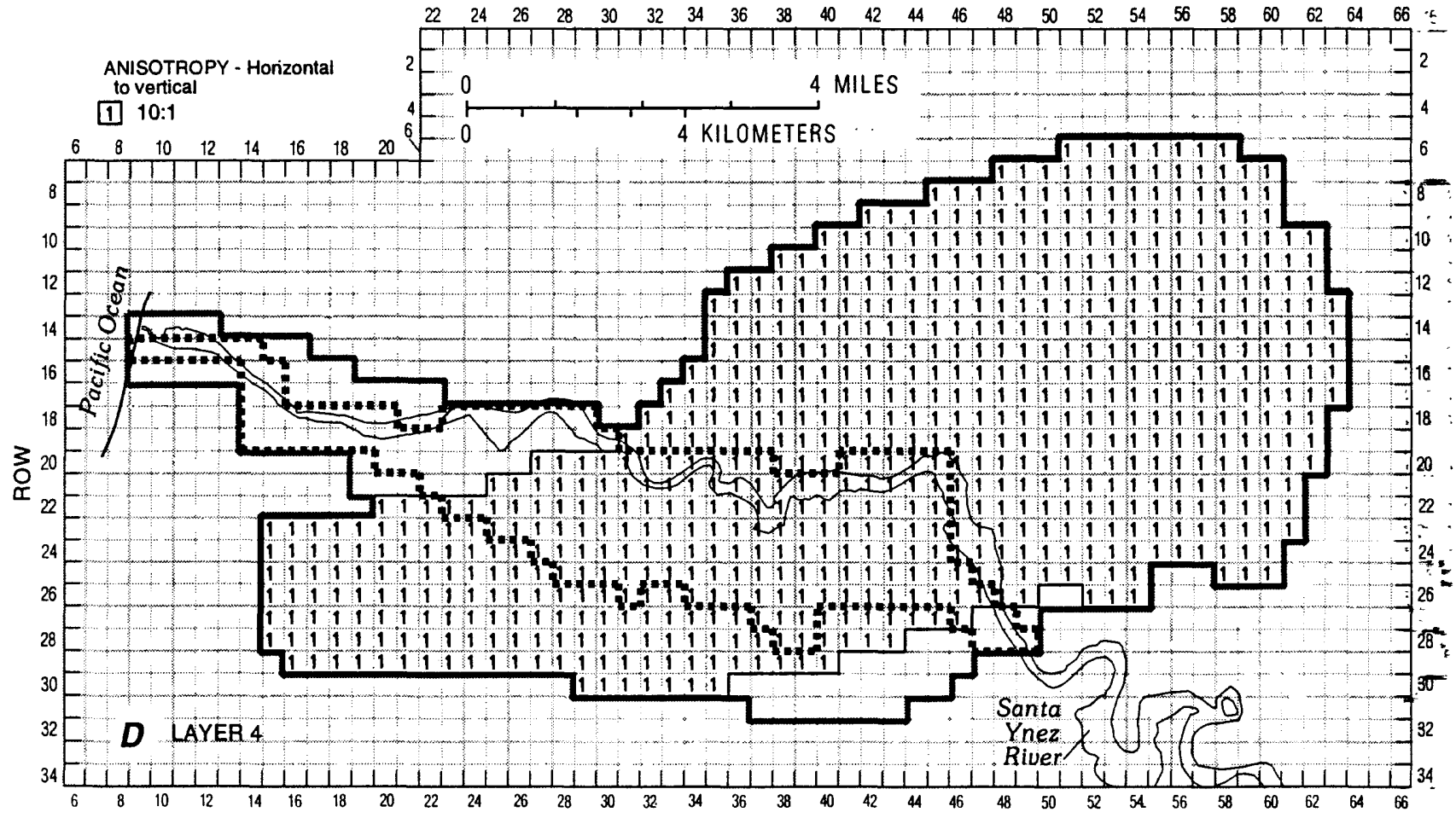

Figure 19.-Continued. 
Municipal pumpage and military pumpage (table 9) were assigned to the closest model cell of a particular well. The vertical distribution of pumpage was simulated by assigning all pumpage values for individual wells to a single model layer. Most of the agricultural and municipal production wells in the Lompoc area yield water from the main zone of the upper aquifer beneath the plain (layer 3 ) or from the lower aquifer beneath the upland and terrace (layer 4). The exception is military pumpage for VAFB and pumpage for USP. Because those supply wells are perforated in both the main zone and lower aquifer, pumpage for these wells was assigned to model layers 3 and 4 . The average quantity of water contributed to these wells from each aquifer was determined by means of dissolved-solids and isotopic mass-balance calculations (table 10). Mass-balance calculations indicate that the main zone of the upper aquifer contributed about 30 percent and the lower aquifer contributed about 70 percent of the water pumped by VAFB and USP in the Lompoc plain.

\section{Drains}

The western plain has been artificially drained since the 1920 's by a network of unlined canals, sloughs, and underground pipes (Virgil Phelps, former director, Santa Ynez River Water Conservation District, oral commun., 1992). Seepage of ground water to drains in the shallow zone was simulated using the drain package (McDonald and Harbaugh, 1988):

where

$$
Q=C(h-H D)
$$

$Q \quad$ is the rate of flow into the drain $\left[\mathrm{L}^{3} \mathrm{~T}^{-1}\right]$,

$C$ is the conductance between the drain and the model cell $\left[\mathrm{L}^{2} \mathrm{~T}^{-1}\right]$,

$h$ is the hydraulic head within the model cell [L],

$H D$ is the altitude of the drain [L].

When the hydraulic head in the model cell $(h)$ is less than the drain altitude $(H D)$, there is no flow into the drain. The conductance of the drain $(C)$ is determined during model calibration (table 11). The altitude of the drain cells is set equal to the average altitude of the surface and subsurface drains in the western plain (about $5 \mathrm{ft}$ below land surface). Ground-water discharge into the subsurface drains is not measured; therefore, the conductance could not be accurately determined and should be considered only an order-of-magnitude estimate.

Table 10. Results of mass-balance calculations of water contributed from the main zone of the upper aquifer and from the lower aquifer to production wells in the northern plain

[mg/L, milligrams per liter; permil, parts per thousand; --, not applicable]

\begin{tabular}{lcclcc}
\hline \multirow{2}{*}{ Zone or aquifer } & \multicolumn{2}{c}{ Dissolved solids } & & \multicolumn{2}{c}{ Isotope (delta oxygen-18) } \\
\cline { 2 - 3 } \cline { 5 - 6 } & $\begin{array}{c}\text { Concentration } \\
(\mathrm{mg} / \mathrm{L})\end{array}$ & $\begin{array}{c}\text { Water } \\
\text { contributed } \\
\text { (percent) }\end{array}$ & & $\begin{array}{c}\text { Concentration } \\
\text { (permil) }\end{array}$ & $\begin{array}{c}\text { Water } \\
\text { contributed } \\
\text { (percent) }\end{array}$ \\
\hline $\begin{array}{l}\text { Combined main zone and } \\
\text { lower aquifer }\end{array}$ & 720 & -- & & -5.60 & -- \\
Main zone & 1,250 & 23 & -5.35 & 38 \\
Lower aquifer & 560 & 77 & & -5.75 & 62 \\
\hline
\end{tabular}


Table 11. Parameters for drain package

[ft, foot; $\mathrm{ft}^{2} / \mathrm{d}$, square foot per day]

\begin{tabular}{cccc}
\hline Row & Column & $\begin{array}{c}\text { Altitude } \\
(\mathrm{ft})\end{array}$ & $\begin{array}{c}\text { Conductance } \\
\left(\mathrm{ft}^{2} / \mathrm{d}\right)\end{array}$ \\
\hline 19 & 20 & 17 & 200 \\
20 & 20 & 19 & 200 \\
21 & 20 & 21 & 200 \\
21 & 21 & 23 & 200 \\
21 & 22 & 25 & 200 \\
22 & 22 & 27 & 200 \\
21 & 23 & 27 & 200 \\
23 & 23 & 29 & 200 \\
21 & 24 & 29 & 200 \\
24 & 24 & 34.3 & 200 \\
22 & 25 & 31.6 & 200 \\
24 & 25 & 36 & 200 \\
22 & 26 & 34.3 & 200 \\
24 & 26 & 37 & 200 \\
22 & 27 & 36 & 200 \\
23 & 27 & 38 & 200 \\
24 & 27 & 40 & 200 \\
24 & 28 & 43 & 200 \\
\hline
\end{tabular}

\section{Evapotranspiration}

Transpiration by phreatophytes along the Santa Ynez River and evaporation from bare-soil areas in the river channel are simulated in the flow model using the evapotranspiration package (McDonald and Harbaugh, 1988). A maximum rate $\left(Q_{\max }\right)$ of $2.8 \mathrm{ft} / \mathrm{yr}$ was used to simulate evapotranspiration when the water table was at land surface, and evapotranspiration was assumed to decrease linearly to zero when the water table was $10 \mathrm{ft}$ below land surface. The extinction depth of $10 \mathrm{ft}$ represents an average depth for deep-rooted (cottonwoods, willows) and shallow-rooted (tules, grass) riparian vegetation along the Santa Ynez River channel. $Q_{\max }$ was proportionally reduced in those model cells for which the plant coverage was less than 100 percent.

The maximum evapotranspiration rate of $2.8 \mathrm{ft} / \mathrm{yr}$ is slightly higher than the rate of $2.2 \mathrm{ft} / \mathrm{yr}$ estimated by the U.S. Bureau of Reclamation (1964-75) for evapotranspiration by riparian vegetation (cottonwood, willow, tules, and grass) with a growth density greater than 70 percent along the Santa Ynez River channel. Analysis of photographs taken in 1939 and 1987 indicate that the density of riparian vegetation ranged from 70 to 100 percent and did not change significantly during the 48 -year period. An exception is in the northwestern plain, where a part of the river channel was converted to irrigated farmland beginning in 1974. Therefore, evapotranspiration along this part of the river channel (cells at row 19, column 25, and row 19, column 26 [table 12]) is not simulated for 1974-88. The 
Table 12. Parameters for evapotranspiration package

[ft, foot; ft/yr, foot per year]

\begin{tabular}{|c|c|c|c|c|c|c|c|}
\hline Row & Column & $\begin{array}{l}\text { Altitude } \\
(\mathrm{ft})\end{array}$ & $\begin{array}{c}\text { Plant } \\
\text { coverage } \\
\text { (percent) }\end{array}$ & Row & Column & $\begin{array}{l}\text { Altitude } \\
(\mathrm{ft})\end{array}$ & $\begin{array}{c}\text { Plant } \\
\text { coverage } \\
\text { (percent) }\end{array}$ \\
\hline 15 & 9 & 0 & 99 & 21 & 33 & 42 & 36 \\
\hline 15 & 10 & 1 & 99 & 20 & 34 & 46 & 32 \\
\hline 15 & 11 & 2 & 99 & 21 & 34 & 55 & 4 \\
\hline 15 & 12 & 3 & 56 & 20 & 35 & 48 & 24 \\
\hline 15 & 13 & 4 & 24 & 21 & 35 & 49 & 52 \\
\hline 16 & 13 & 5 & 32 & 21 & 36 & 50 & 68 \\
\hline 16 & 14 & 7 & 40 & 22 & 36 & 50 & 12 \\
\hline 17 & 14 & 15 & 8 & 22 & 37 & 51 & ${ }^{1} 68$ \\
\hline 16 & 15 & 8 & 2 & 23 & 37 & 65 & ${ }^{1} 44$ \\
\hline 17 & 15 & 10 & 40 & 21 & 38 & 56 & ${ }^{1} 40$ \\
\hline 18 & 15 & 11 & 4 & 22 & 38 & 54 & ${ }^{1} 68$ \\
\hline 17 & 16 & 15 & 4 & 23 & 38 & 65 & ${ }^{1} 20$ \\
\hline 18 & 16 & 12 & 24 & 21 & 39 & 58 & ${ }^{1} 99$ \\
\hline 18 & 17 & 14 & 44 & 22 & 39 & 70 & ${ }^{1} 12$ \\
\hline 18 & 18 & 15 & 40 & 21 & 40 & 60 & ${ }^{1} 96$ \\
\hline 18 & 19 & 17 & 28 & 22 & 40 & 70 & ${ }^{1} 8$ \\
\hline 19 & 19 & 18 & 28 & 21 & 41 & 61 & ${ }^{1} 76$ \\
\hline 18 & 20 & 18 & 24 & 21 & 42 & 62 & ${ }^{1} 64$ \\
\hline 19 & 20 & 20 & 40 & 20 & 43 & 64 & ${ }^{1} 4$ \\
\hline 18 & 21 & 20 & 48 & 21 & 43 & 64 & ${ }^{1} 56$ \\
\hline 19 & 21 & 21 & 32 & 20 & 44 & 66 & ${ }^{1} 52$ \\
\hline 18 & 22 & 23 & 68 & 21 & 44 & 80 & ${ }^{1} 12$ \\
\hline 19 & 22 & 22 & 8 & 20 & 45 & 68 & ${ }^{1} 84$ \\
\hline 18 & 23 & 24 & 52 & 21 & 45 & 71 & ${ }^{1} 52$ \\
\hline 18 & 24 & 26 & 72 & 22 & 45 & 85 & ${ }^{1} 8$ \\
\hline 18 & 25 & 27 & 84 & 23 & 45 & 90 & ${ }^{1} 12$ \\
\hline 19 & 25 & 35 & ${ }^{2} 76$ & 20 & 46 & 90 & ${ }^{1} 20$ \\
\hline 18 & 26 & 28 & 84 & 21 & 46 & 72 & ${ }^{1} 76$ \\
\hline 19 & 26 & 40 & ${ }^{2} 32$ & 22 & 46 & 74 & ${ }^{1} 84$ \\
\hline 18 & 27 & 29 & 40 & 23 & 46 & 76 & ${ }^{1} 96$ \\
\hline 18 & 28 & 30 & 72 & 24 & 46 & 78 & ${ }^{1} 56$ \\
\hline 19 & 28 & 45 & 4 & 23 & 47 & 76 & ${ }^{1} 60$ \\
\hline 18 & 29 & 32 & 60 & 24 & 47 & 78 & 199 \\
\hline 19 & 29 & 34 & 48 & 25 & 47 & 80 & ${ }^{1} 76$ \\
\hline 19 & 30 & 36 & 60 & 26 & 47 & 81 & ${ }^{1} 32$ \\
\hline 19 & 31 & 38 & 20 & 24 & 48 & 95 & ${ }^{1} 8$ \\
\hline 20 & 31 & 39 & 52 & 25 & 48 & 90 & ${ }^{1} 28$ \\
\hline 21 & 31 & 40 & 12 & 26 & 48 & 85 & ${ }^{1} 24$ \\
\hline 21 & 32 & 41 & 28 & 27 & 48 & 90 & ${ }^{1} 52$ \\
\hline \multirow[t]{2}{*}{20} & 33 & 44 & 4 & 28 & 48 & 95 & ${ }^{1} 32$ \\
\hline & & & & 28 & 49 & 100 & ${ }^{1} 28$ \\
\hline
\end{tabular}

$Q_{\max }$ is $1.0 \mathrm{ft} / \mathrm{yr}$ for $1960-88$.

${ }^{2}$ plant coverage is 0 percent for $1974-88$. 
reach of the Santa Ynez River from Robinson Bridge to the LRWTP also underwent significant change. Sand- and gravel-mining operations since the early 1960's have removed much of the riparian vegetation in this part of the river channel. $Q_{\max }$ was reduced to $1.0 \mathrm{ft} / \mathrm{yr}$ to simulate this change in vegetation for the model cells in this area for 1960-88 (table 12). This value is slightly higher than the rate of 0.67 estimated by the U.S. Bureau of Reclamation (1964-75) for lightdensity riparian vegetation (10 to 40 percent) along the Santa Ynez River.

\section{Aquifer Properties}

\section{Transmissivity}

Transmissivity values are a product of hydraulic conductivity and the thickness of the aquifer material through which flow occurs. Therefore, these values are affected by changes in saturated thickness. In this model transmissivity values are held constant for all model layers during each simulation. When using a constant transmissivity, errors are introduced where water-level changes are a significant percentage of the total saturated thickness of an unconfined aquifer. Where the lower aquifer is unconfined, water-level changes are less than 10 percent of the total saturated thickness of the aquifer, and they have little effect on transmissivity. Where the shallow zone (layer 1) is unconfined in the Lompoc plain, the transmissivity is dominated by the sand and gravel deposits that occur near the base of this zone. Observed water-level changes in parts of the shallow zone are greater than 10 percent of the saturated thickness of the zone, but the water table is significantly above the basal sand and gravel deposits and is in the finer grained silt and clay units. Therefore, changes in saturated thickness does not appreciably alter the transmissivity of the shallow zone and the use of constant transmissivity values is considered reasonable.

The initial distribution of transmissivity used in the model was estimated from single-well aquifer tests, slug tests, and specific-capacity data. Transmissivity data were extrapolated to areas lacking data by applying estimated hydraulic-conductivity values to areas of similar lithology, on the basis of geologic well logs. Transmissivities then were calculated by multiplying the extrapolated hydraulic conductivity by the estimated thickness of each water-bearing zone or aquifer. Estimates of transmissivity for the uplands and terrace were proportioned to the four layers on the basis of layer thickness. Layers 1,2 , and 3 have constant thickness of 50, 45, and 85 $\mathrm{ft}$, and layer 4 has a variable thickness (fig. 20). The extrapolation to the lower aquifer assumes that the hydraulic conductivity of the lower aquifer is constant with depth. The resulting hydraulicconductivity distribution for the lower aquifer is shown in figure 21 . Estimated values of transmissivity range from $18 \mathrm{ft}^{2} / \mathrm{d}$ in the shallow zone of the upper aquifer beneath the northern plain to about $25,000 \mathrm{ft}^{2} / \mathrm{d}$ in the main zone near the Narrows (table 13). Initial estimates of transmissivity were modified during the steady-state calibration of the model until the final distribution of transmissivity for each layer was derived (fig. 22).

Estimated and model-calibrated transmissivity values are given in table 13 . The modelcalibrated transmissivity values were generally higher than the estimated values from the shallow and middle zones of the upper aquifer. The estimated values for these zones were from single-well aquifer tests done on 2-inch monitor wells, with the exception of permeability test done along the Santa Ynez River. Aquifer tests on the small-diameter monitor wells probably underestimated the true transmissivity of the aquifer owing to the limited pumping rate of a 2-inch well. The modelcalibrated transmissivity values of the main zone of the upper aquifer and the lower aquifer were generally similar to the estimated values (table 13 ). 


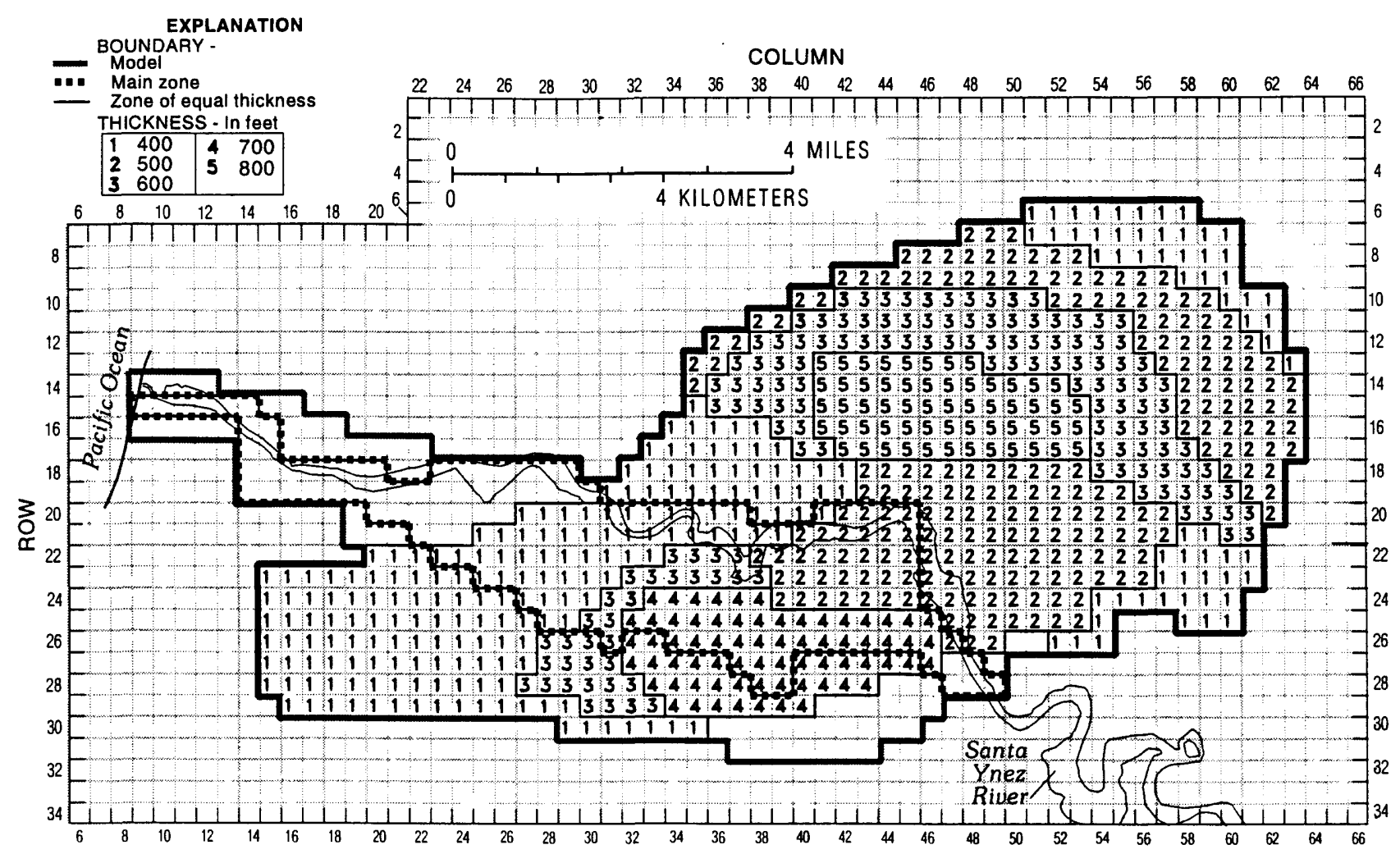

Figure 20. Areal distribution of thickness for layer 4, lower aquifer in the Lompoc area. BOUNDARY EXPLANATION

- Model $\because$ Main zone - Zone of equal hydraulic conductivity COLUMN

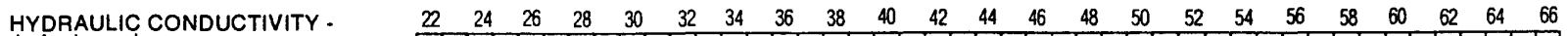
\begin{tabular}{l} 
In feet per day \\
\begin{tabular}{|ll|ll|ll|}
\hline 1 & 0.35 & $\mathbf{5}$ & 4.40 & $\mathbf{9}$ & 9.70 \\
2 & 1.80 & $\mathbf{6}$ & 7.00 & $\mathbf{A}$ & 10.0 \\
3 & 2.50 & $\mathbf{7}$ & 8.10 & B & 18.5 \\
4 & 3.00 & 8 & 8.50 & $\mathbf{C}$ & 23.0 \\
\hline
\end{tabular} \\
\hline
\end{tabular}

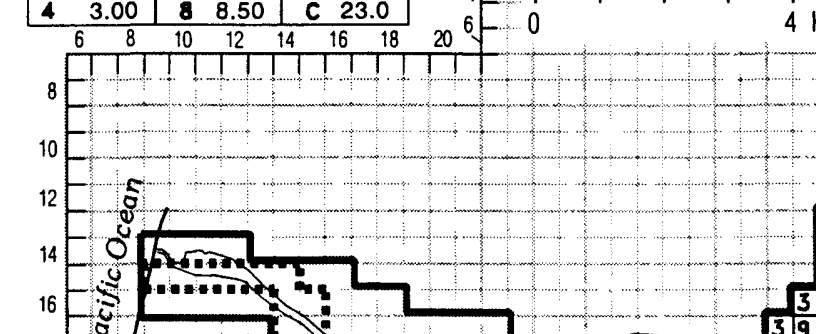
4 KILOMETERS

4 MILES

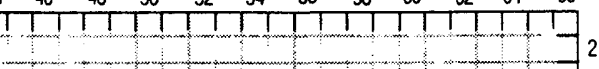


Table 13. Estimated and model-calibrated transmissivity values

[Row, column: see figure 22. State well No.: see well-numbering system in text and figure 2; Transmissivity: see figure 22 for distributions of model-calibrated transmissivity values. $\mathrm{ft}^{2} / \mathrm{d}$, foot squared per day; $\mathrm{ft}$, foot]

\begin{tabular}{|c|c|c|c|c|c|}
\hline \multirow{2}{*}{$\begin{array}{c}\text { Model layer in } \\
\text { which well is } \\
\text { perforated }\end{array}$} & \multirow[b]{2}{*}{ Row } & \multirow[b]{2}{*}{ Column } & \multirow[b]{2}{*}{$\begin{array}{c}\text { State well } \\
\text { number }\end{array}$} & \multicolumn{2}{|c|}{ Transmissivity $\left(\mathrm{ft}^{2} / \mathrm{d}\right)$} \\
\hline & & & & Estimated & $\begin{array}{c}\text { Model } \\
\text { calibrated }\end{array}$ \\
\hline \multicolumn{6}{|c|}{ Upper Aquifer, Shallow Zone } \\
\hline 1 & 23 & 36 & $7 \mathrm{~N} / 34 \mathrm{~W}-29 \mathrm{~F} 2$ & 18 & 100 \\
\hline 1 & 25 & 34 & $7 N / 34 W-29 N 4$ & 46 & 50 \\
\hline 1 & \multicolumn{3}{|c|}{ (Santa Ynez River alluvium $)^{1}$} & $2,840-10,160$ & $3,000-8,650$ \\
\hline \multicolumn{6}{|c|}{ Upper Aquifer, Middle Zone } \\
\hline 2 & 23 & 38 & $7 \mathrm{~N} / 34 \mathrm{~W}-29 \mathrm{H} 3$ & 90 & 400 \\
\hline 2 & 21 & 25 & $7 \mathrm{~N} / 35 \mathrm{~W}-23 \mathrm{Q} 3$ & 94 & 400 \\
\hline 2 & 24 & 24 & $7 \mathrm{~N} / 35 \mathrm{~W}-26 \mathrm{~L} 2$ & 106 & 1,000 \\
\hline \multicolumn{6}{|c|}{ Upper Aquifer, Main Zone } \\
\hline 3 & 23 & 45 & $7 \mathrm{~N} / 34 \mathrm{~W}-27 \mathrm{~K} 7$ & 17,250 & 16,000 \\
\hline 3 & 26 & 44 & 7N/34W-34F6 & 15,300 & 16,000 \\
\hline 3 & 27 & 46 & $7 \mathrm{~N} / 34 \mathrm{~W}-34 \mathrm{H} 1$ & ${ }^{2} 24,750$ & 16,000 \\
\hline 3 & 19 & 29 & $7 \mathrm{~N} / 35 \mathrm{~W}-24 \mathrm{~K} 5$ & 12,350 & 16,000 \\
\hline \multicolumn{6}{|c|}{ Lower Aquifer } \\
\hline 2 & 28 & 30 & $7 \mathrm{~N} / 35 \mathrm{~W}-36 \mathrm{~J} 6$ & ${ }^{3} 7,350$ & ${ }^{4} 7,645$ \\
\hline 4 & 22 & 58 & $7 \mathrm{~N} / 33 \mathrm{~W}-19 \mathrm{Q} 2$ & 4,800 & 5,580 \\
\hline 4 & 14 & 43 & $7 \mathrm{~N} / 34 \mathrm{~W}-15 \mathrm{D} 3$ & 20,700 & ${ }^{5} 6,830$ \\
\hline 4 & 23 & 45 & $7 \mathrm{~N} / 34 \mathrm{~W}-27 \mathrm{~K} 6$ & 4,800 & 4,050 \\
\hline 4 & 25 & 34 & $7 \mathrm{~N} / 34 \mathrm{~W}-29 \mathrm{~N} 7$ & 13,000 & 12,950 \\
\hline 4 & 24 & 24 & $7 \mathrm{~N} / 35 \mathrm{~W}-26 \mathrm{~L} 4$ & 850 & ${ }^{6} 2,130$ \\
\hline
\end{tabular}

${ }^{\mathrm{I}}$ Calculated from permeability test on samples of bed materials along the Santa Ynez River (Upson and Thomasson, 1951, table 16 , p. 79) using an average saturated thickness of $50 \mathrm{ft}$.

${ }^{2}$ Reported transmissivity from aquifer test done in March 1955 (U.S. Geological Survey data files, San Diego, California).

${ }^{3}$ Reported transmissivity from aquifer test done in December 1952 (U.S. Geological Survey data files, San Diego, California).

Well is perforated in terrace deposits beneath southern Lompoc plain.

${ }^{4}$ Equals total transmissivity of model layers 2,3 , and 4 .

${ }^{5}$ Equals total transmissivity of model layers $1,2,3$, and 4.

${ }^{6}$ Equals total transmissivity of model layers 3 and 4 . 

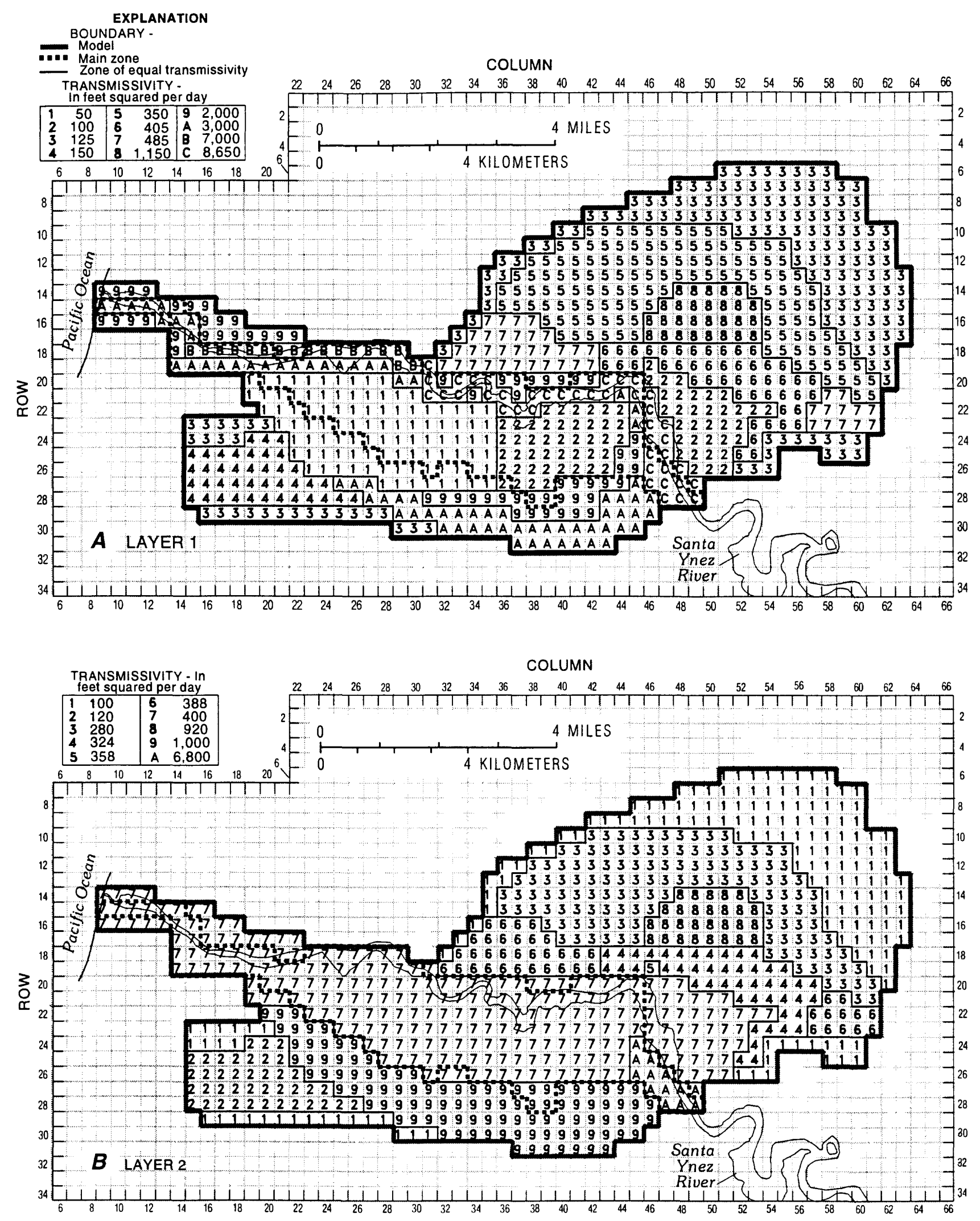

Figure 22. Areal distribution of transmissivity in flow model in the Lompoc area: $(A)$ layer 1, (B) layer 2. (C) layer 3, (D) layer 4. 

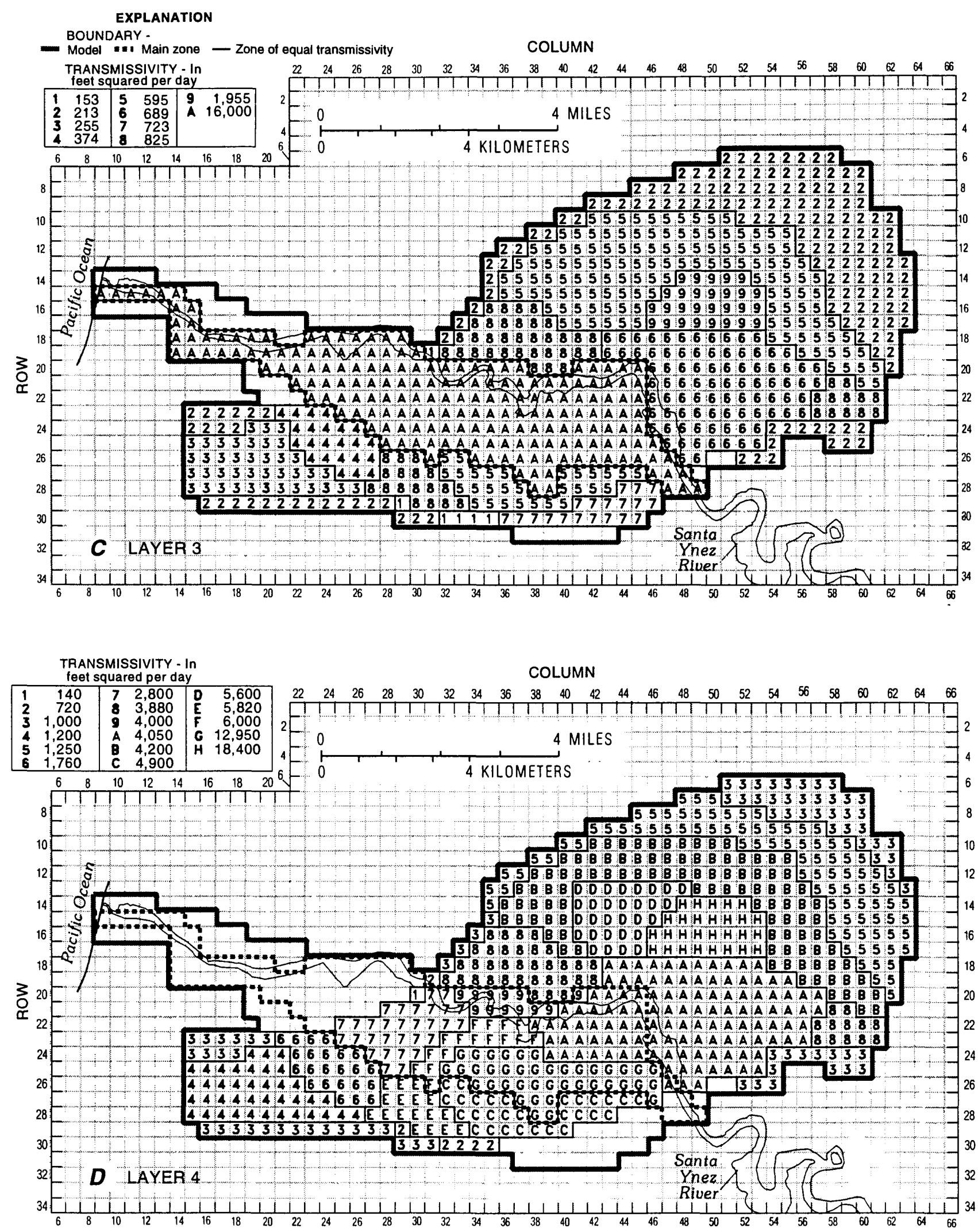

Figure 22.-Continued. 
Vertical leakage from one layer to another occurs whenever there is a difference in hydraulic head between layers. The rate at which leakage occurs is determined by the following equation:

$$
Q=\frac{K_{v} \cdot D E L R_{j} \cdot D E L C_{i}\left(H_{k}-H_{k+1}\right)}{B}
$$

where:

$Q \quad$ is the vertical leakage $\left[\mathrm{L}^{3} / \mathrm{T}\right]$,

$K_{\mathrm{v}}$ is the effective value of vertical hydraulic conductivity between the center of cell $i, j, k$ and cell $i, j, k+1[\mathrm{~L} / \mathrm{T}]$,

$D E L R j$ is the cell width along row $j[\mathrm{~L}]$,

$D E L C i$ is the cell width along column $i[\mathrm{~L}]$,

$B$ is the distance between the centers of model layer $k$ and $k+1$ [L],

$H_{\mathrm{k}}$ is the hydraulic head in cell $i, j, k$ [L],

$H_{\mathrm{k}+1}$ is the hydraulic head in cell $i, j, k+1[\mathrm{~L}]$,

cell $i, j, k$ represents a model cell in row $i$, column $j$, and layer $k$ [dimensionless], and cell $i, j, k+1$ represents a model cell in row $i$, column $j$, and layer $k+1$ [dimensionless].

The quantity $K_{\mathrm{v}} / B$ in the above equation is referred to as the vertical leakance term and is designated $V_{\text {cont }}$ in this report. The ground-water flow model requires that user specifies the term $V_{\text {cont }}$ as input data. $V_{\text {cont }}$, is calculated using the following equation ( modified from McDonald and Harbaugh, 1988, p. 5-13):

where

$$
\operatorname{ccont}_{i, j, k+1 / 2}=\frac{1}{\left(\frac{B_{k}^{2} / 2}{T_{i, j, k} / A_{i, j, k}}\right)+\left(\frac{B_{k+1}^{2} / 2}{T_{i, j, k+1} / A_{i, j, k+1}}\right)},
$$

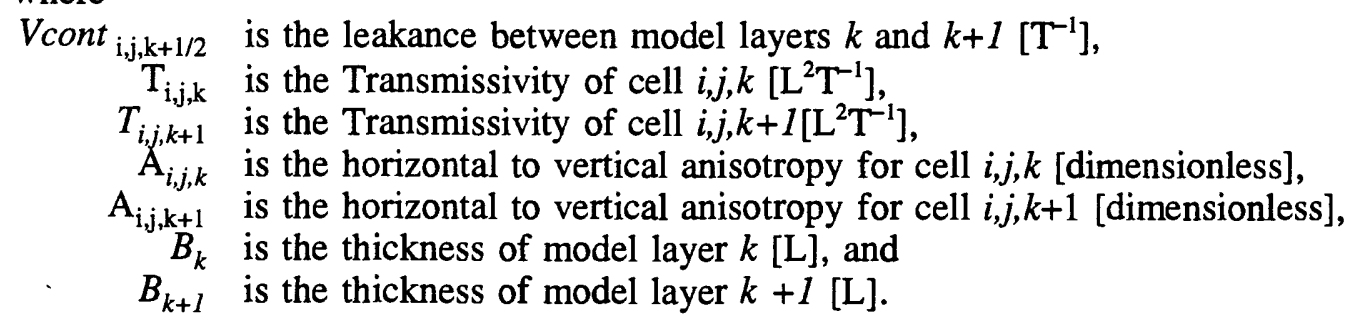

The distribution of transmissivity and horizontal to vertical anisotropy for the different model layers are presented in figures 22 and 23 . The calculated $V_{\text {cont }}$ distributions between model layers 1 and 2, 2 and 3, and 3 and 4 are presented in figure 24. Few adjustments were made during steady-state calibration to initial estimates of $V_{\text {cont }}$ because steady-state water levels were relatively insensitive to this parameter and few data were available for calibration. Therefore, adjustments to this parameter were limited primarily to calibration for transient conditions and involved adjusting estimates of horizontal to vertical anisotropy. The initial estimate of horizontal to vertical anisotropy were based on the thickness of silt and clay layers and the amount of layering observed in geologic and geophysical logs. The calibration was made by comparing simulated hydraulic-head differences between model layers with measured hydraulic-head differences between aquifers and water-bearing zones at various multiple-well sites in the Lompoc plain (fig. 10). The calibrated horizontal to vertical anisotropy 


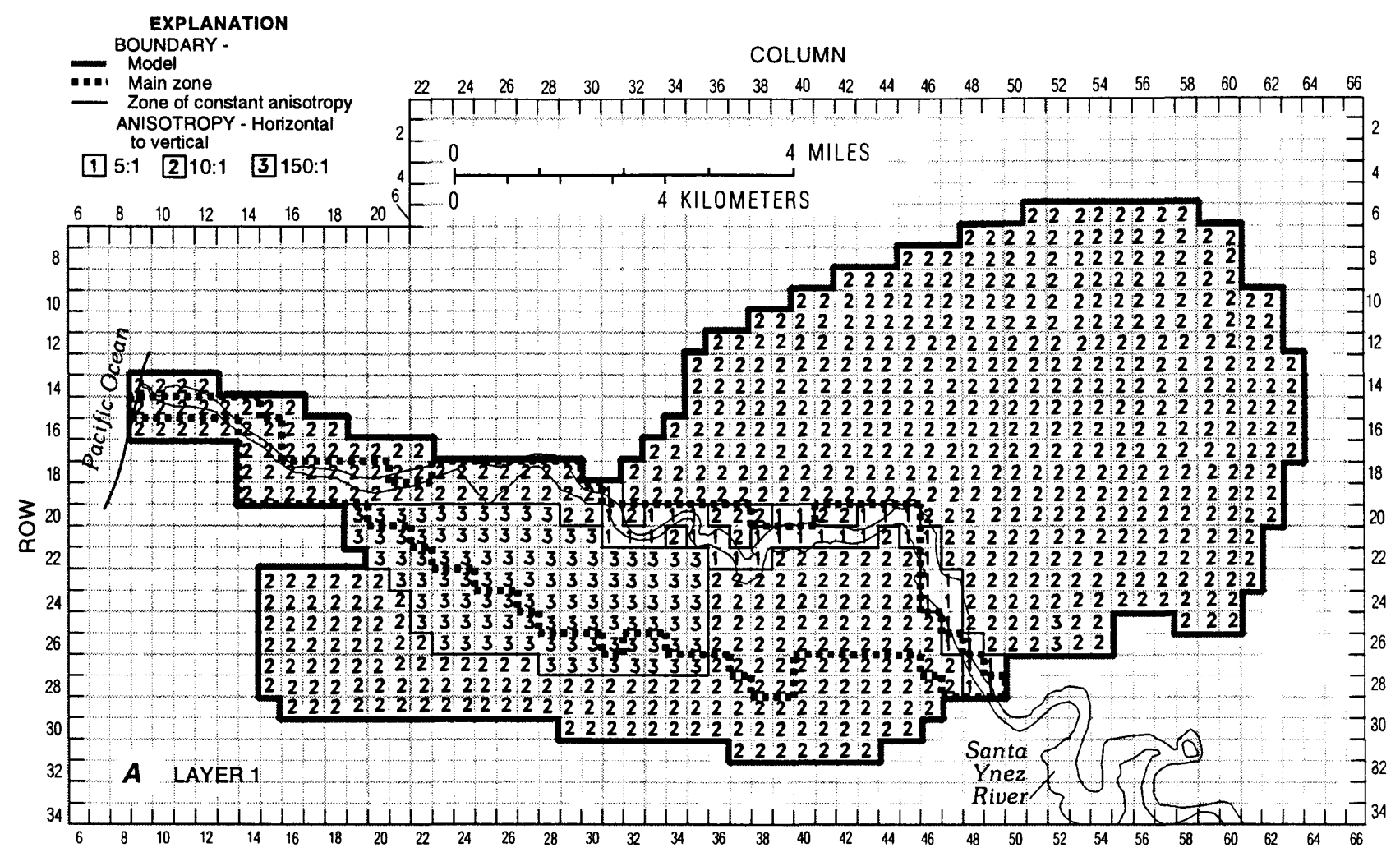

COLUMN

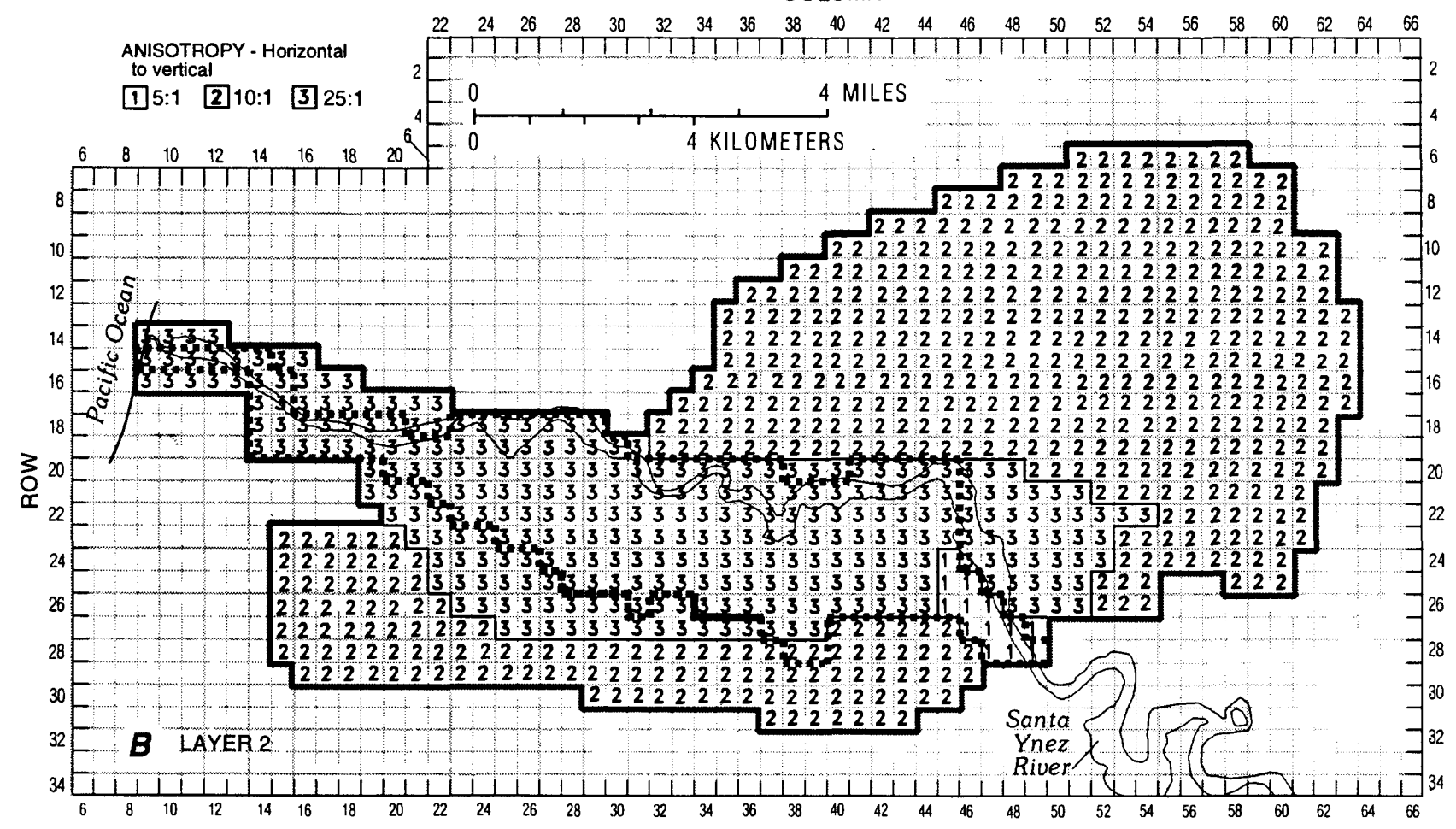

Figure 23. Areal distribution of horizontal to vertical anisotropy in flow model in the Lompoc area: $(A)$ layer 1, $(B)$ layer 2, $(C)$ layer 3, $(D)$ layer 4. 

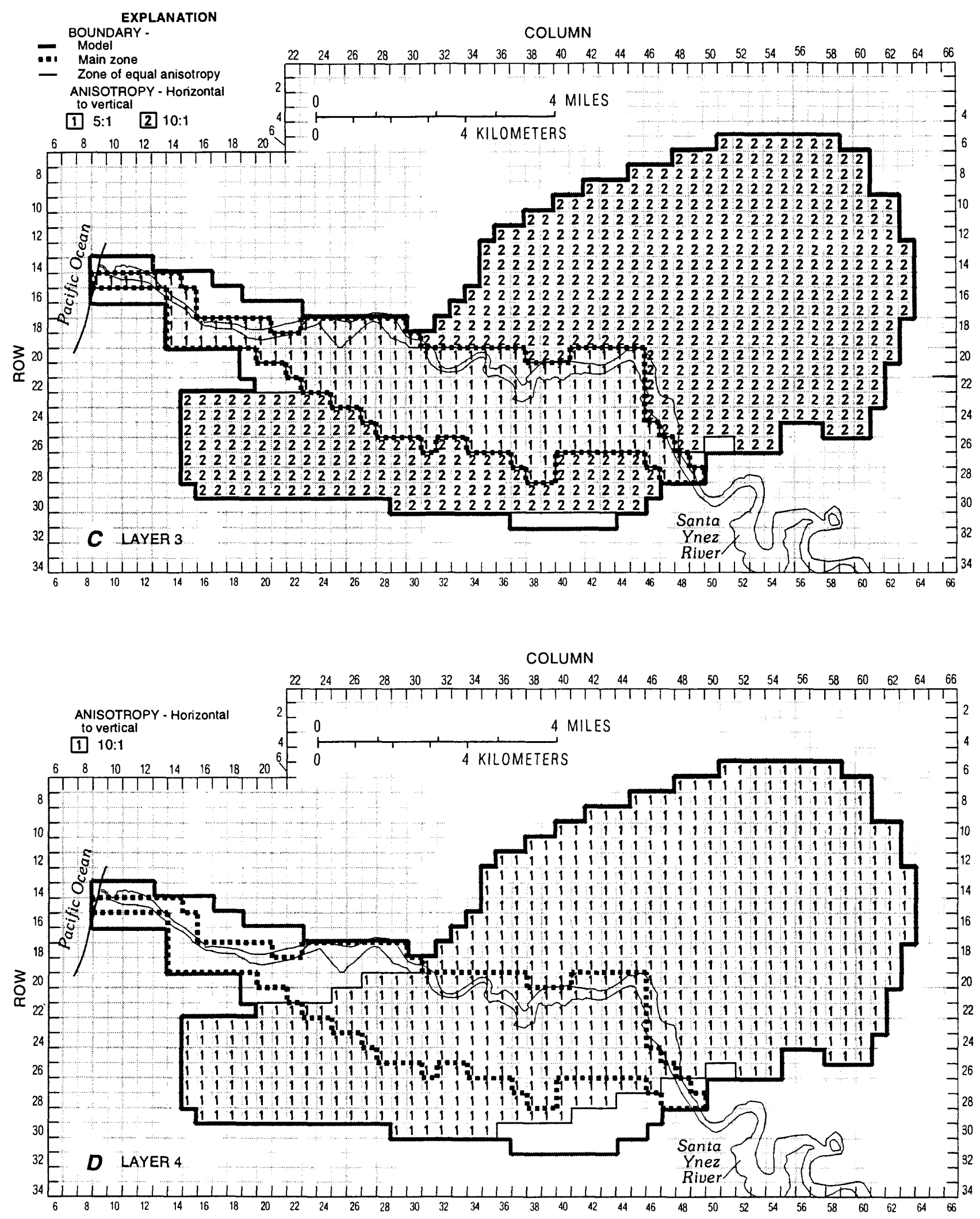

Figure 23.-Continued. 

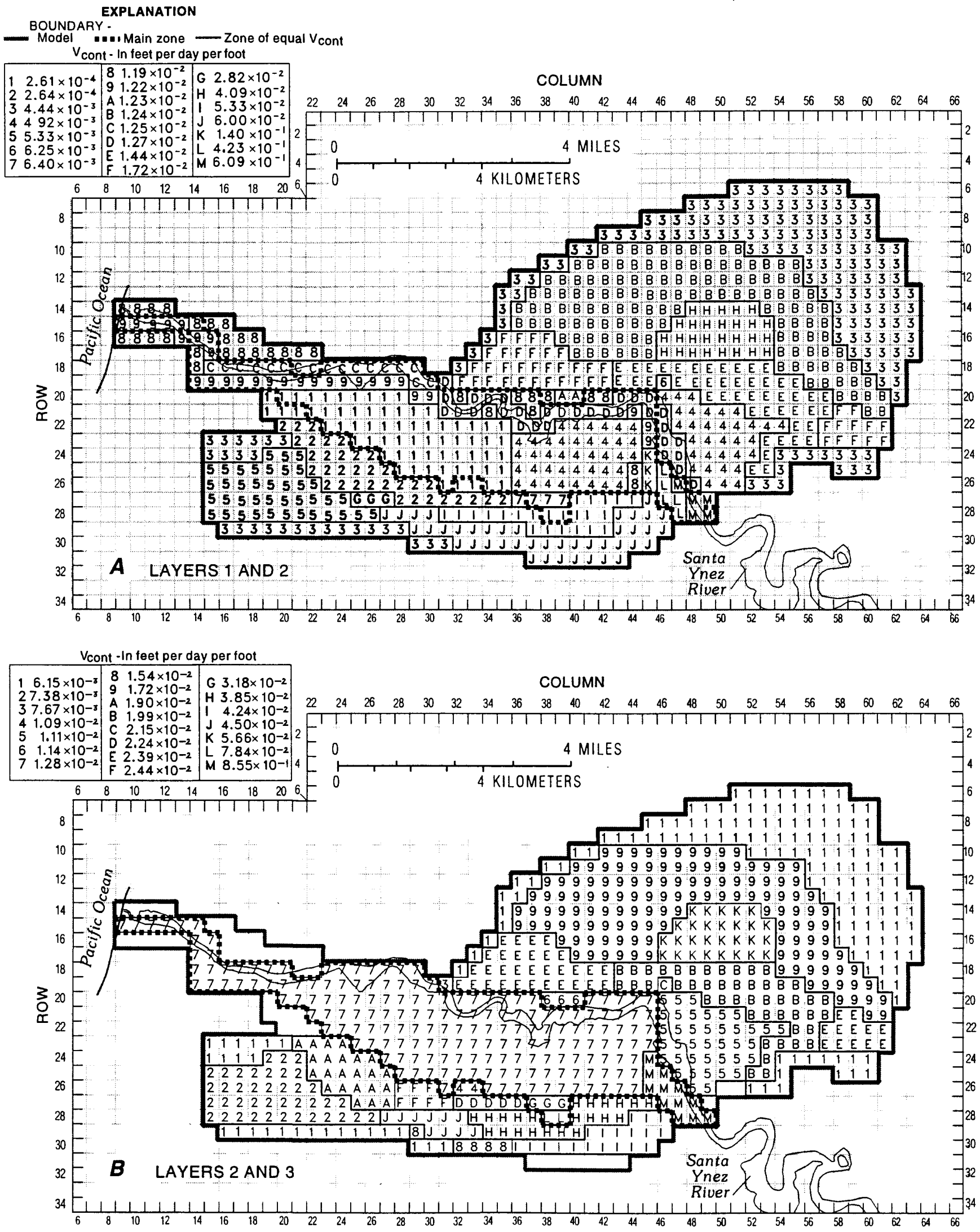

Figure 24. Areal distribution of Vcont between layers in flow model in the Lompoc area: $(A)$ layer $1,(B)$ layer 2, (C) layer 3 and 4. 


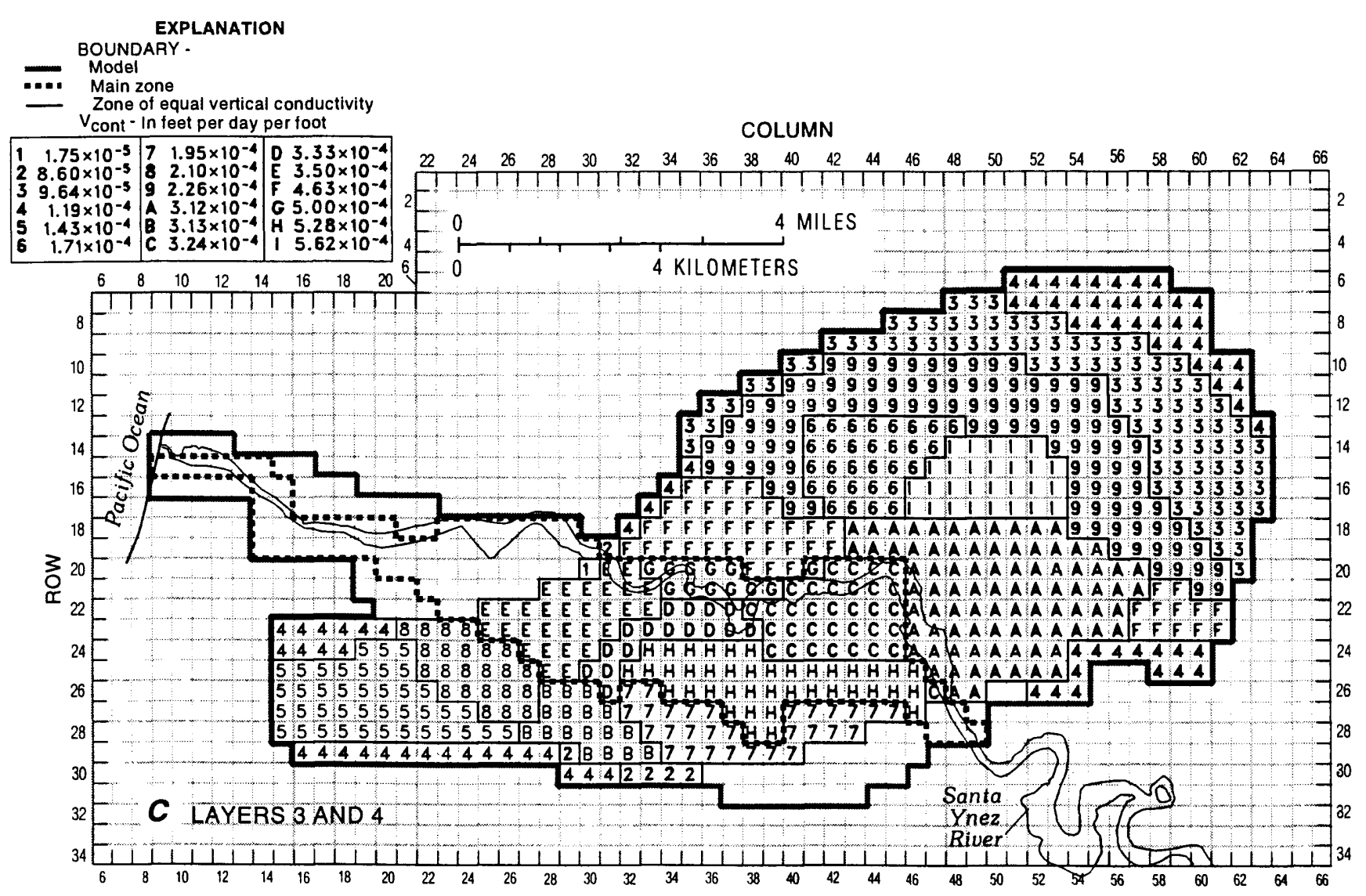

Figure 24.-Continued.

values ranged from 150:1 in the shallow zone beneath the central and western plains where there are thick silt and clay layers to 5:1 in the shallow zone beneath parts of Santa Ynez River where sand and gravel deposits are present. A value of 10:1 was simulated for the entire lower aquifer. The lower aquifer consists of alternating coarse-sand fine-grained layers (table 1). Freeze and Cherry (1979, p.34) reported that it is not uncommon for layered heterogeneity to lead to regional anisotropy values on the order of 100:1 or even larger. Depth dependent data were not available in the lower aquifer to calibrate the anisotropy of the lower aquifer.

\section{Storage Coefficient}

Layer 1 was simulated as unconfined in all modeled areas. Water-level data, where available, indicate that fluctuations in the water table occur within the shallow deposits in these unconfined areas. Estimates of specific yield by Wilson (1959) for the shallow-zone deposits range from 0.08 beneath the western plain to 0.18 beneath the eastern plain. Model cells representing the area of silt and clay deposits in the western, central, and northeastern plains were assigned a specific yield of 0.08 (fig. 25). Along the perimeter of the plain and outside the area of abundant silt and clay, model cells were assigned a specific yield of 0.12 (Wilson, 1959). Model cells representing the Santa Ynez River channel deposits were assigned a specific yield of 0.30 . For the upland and terrace, a specific-yield of 0.20 was used to simulate unconfined storage conditions in layer 1 (fig. 25). These values were obtained in part by model calibration, and they are appropriate for the geologic materials in the lower aquifer (Freeze and Cherry, 1979, p. 61). 


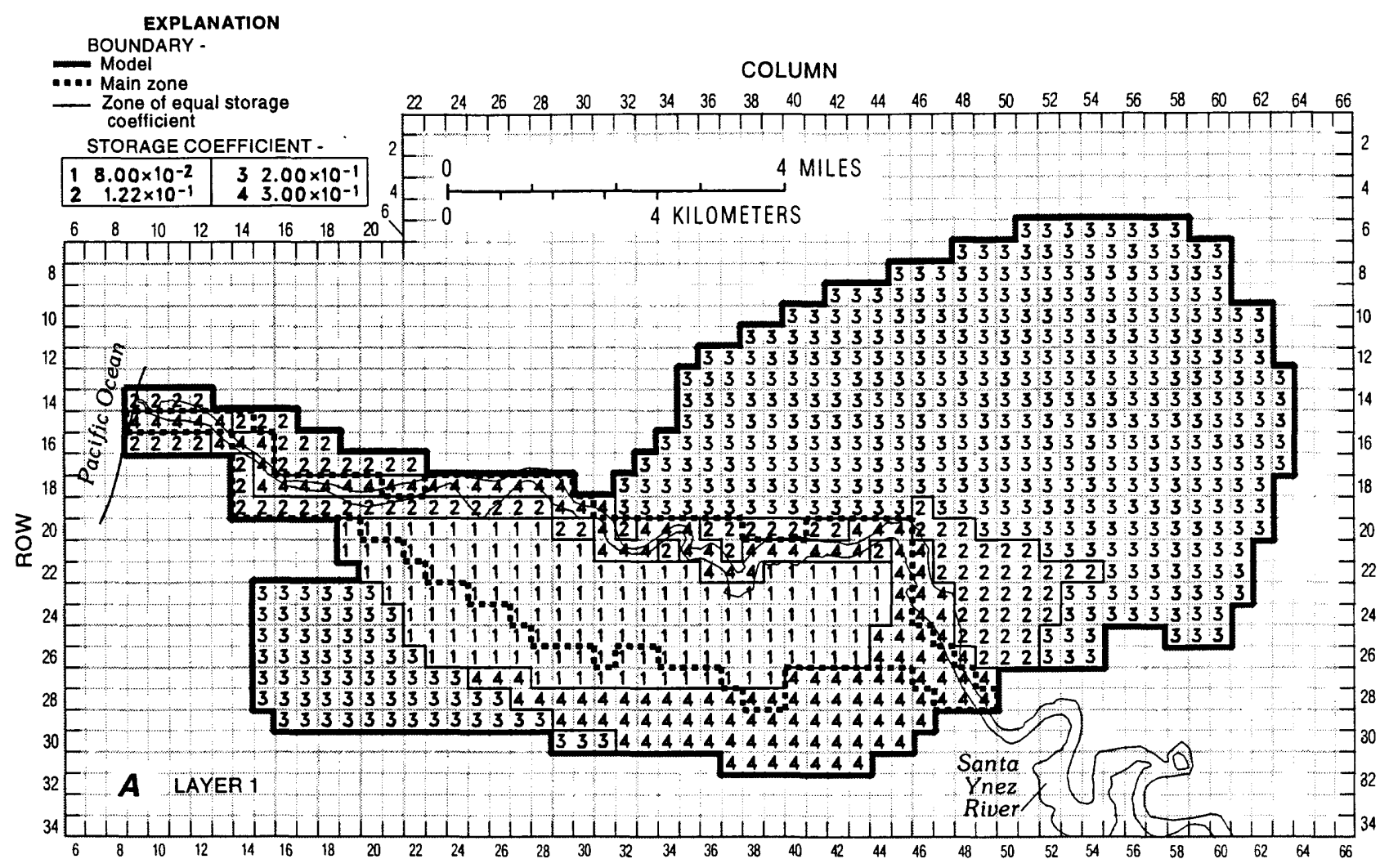

COLUMN

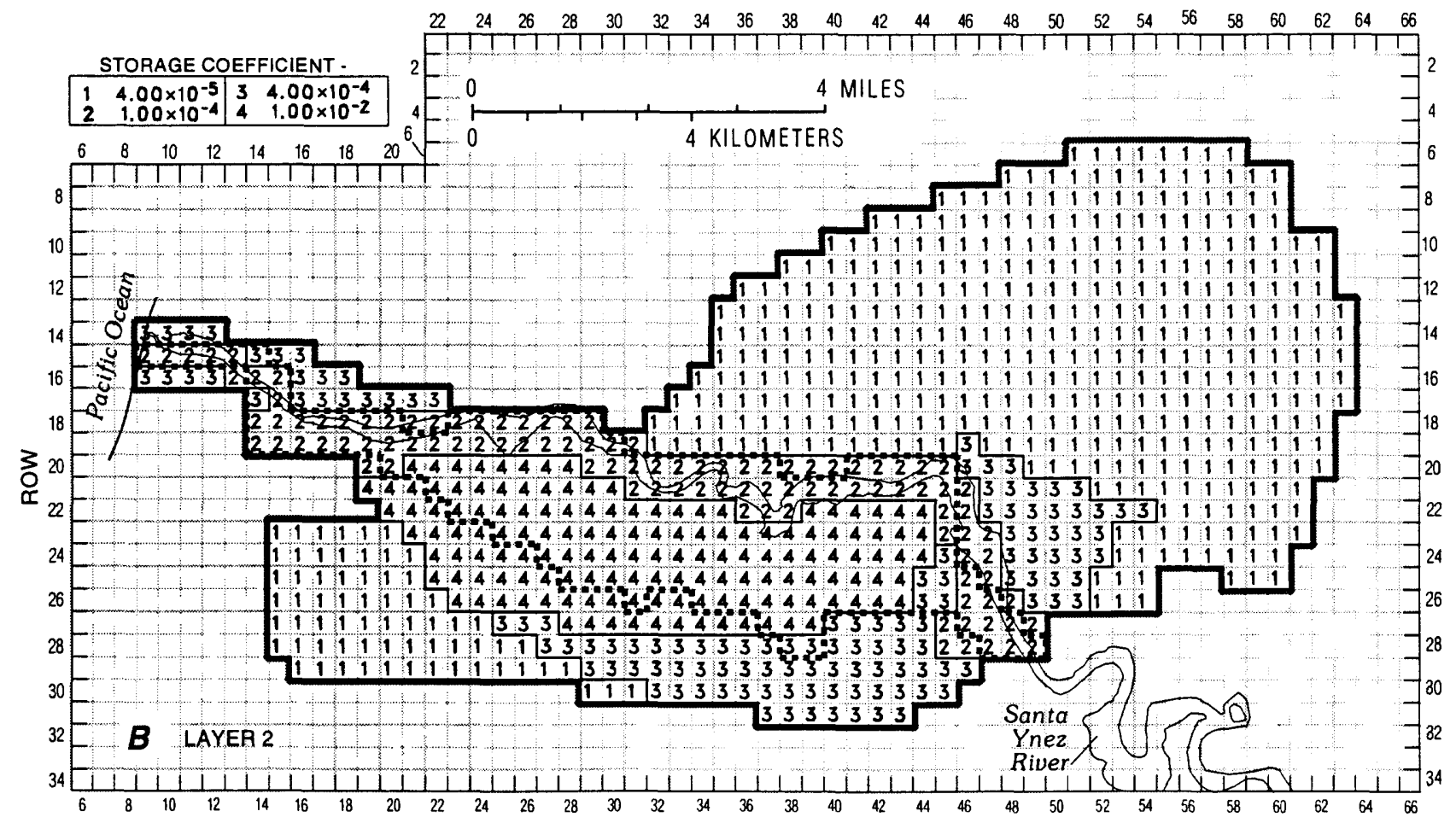

Figure 25. Areal distribution of storage coefficient in flow model in the Lompoc area: $(A)$ layer $1,(B)$ layer 2, (C) layer 3, (D) layer 4. 


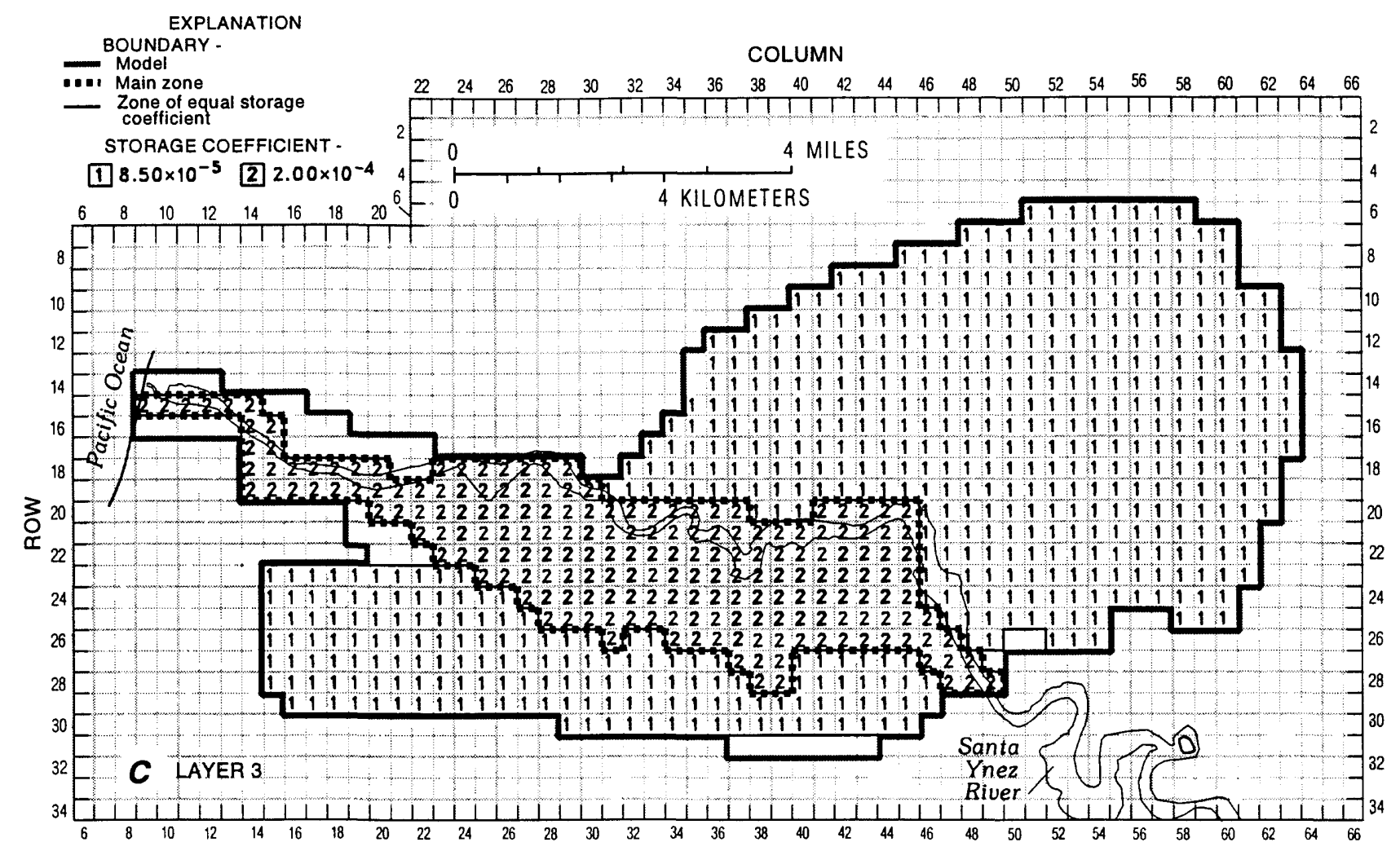

COLUMN

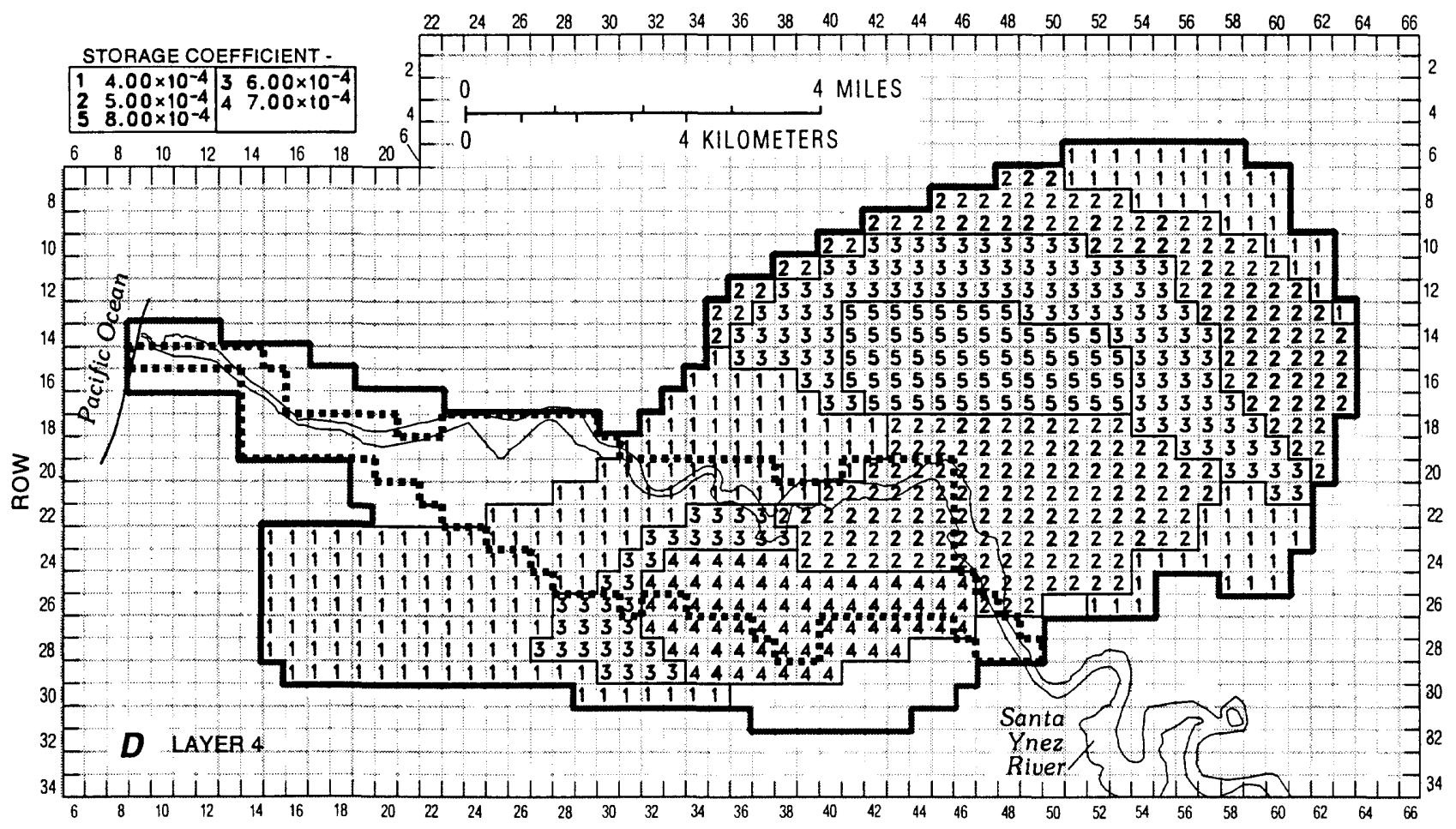

Figure 25.-Continued. 
Layers 2, 3, and 4 were simulated as confined in all model areas. Values of storage coefficient for the confined aquifers in the Lompoc area have not been estimated in previous reports. The storage coefficient of layers 2,3 , and 4 in the uplands and terrace and layer 4 beneath the plain was estimated by multiplying the layer thickness by a specific storage of $1 \times 10^{-6} \mathrm{ft}^{-1}$. This value of specific storage was reported by Lohman $(1977$, p. 53$)$ to be representative of sandstone aquifers that are similar to the Carega Sand of the lower aquifer.

Values of storage coefficient for layers 2 and 3 beneath the plain were derived by geohydrologic interpretation and by estimating the specific storage of each aquifer or zone. For modeling purposes, the compressibility of water was considered negligible, and the specific storage was assumed to be equal to the unit weight of water times the aquifer compressibility (Freeze and Cherry, 1979, p. 59). Estimates of specific storage were (table 14) made using a range of measured values of compressibility for clay, sand, and gravel (Freeze and Cherry, 1979, table 2.5), and the average thickness of these components for different parts of the plain shown by representative well logs. Initial values of storage coefficient then were calculated using the following equation:

$$
S=\rho g\left(b_{1} \beta_{1}+b_{2} \beta_{2}+b_{3} \beta_{3}\right)
$$

where:

$S$ is the storage coefficient [dimensionless],

$\rho g$ is the unit weight of water $\left[62.4 \mathrm{lb} / \mathrm{ft}^{3}\right]$,

$b_{n}$ is the thickness of clay $\left(b_{1}\right)$, sand $\left(b_{2}\right)$, or gravel $\left(b_{3}\right)$ deposits [ft], and

$\beta_{n}$ is the compressibility of clay $\left(\beta_{1}\right)$, sand $\left(\beta_{2}\right)$, or gravel $\left(\beta_{3}\right)$ deposits [ $\mathrm{ft}^{2} / \mathrm{lb}$ ], for which approximate values (Freeze and Cherry, 1979, table 2.5, p. 55) are:

$\beta_{1}: 5 \times 10^{-5}-5 \times 10^{-7}$

$\beta_{2}: 5 \times 10^{-6}-5 \times 10^{-8}$

$\beta_{3}: 5 \times 10^{-7}-5 \times 10^{-9}$

Estimated storage coefficients calculated using equation 8 and model-calibrated storage coefficients are given in table 14. The estimated values were adjusted slightly during the transient calibration. The calibrated distribution of storage coefficient for each layer is presented in figure 25 . The storage coefficients remain constant during the simulation. Therefore, the effects of inelastic compressibility of the aquifer material were ignored. In fact, the compressibility of some aquifer materials can be much less in expansion than in compression (Freeze and Cherry, 1979, p. 56).

A storage coefficient of 0.01 was used to simulate confined conditions in the western, central, and northeastern plains, and part of the northern plain in layer 2 (middle zone of the upper aquifer). This value is about two orders of magnitude larger than the storage coefficients used for layers 2 and 3 along the perimeter of the plain (0.0001-0.0004; table 14 and fig. 25). The larger storage coefficient reflects the increased silt and clay content of the upper aquifer in this area (fig. 6). Storage coefficients for silt and clay deposits or confining-unit materials have been reported to be as much as two orders of magnitude greater than the storage coefficients for aquifer materials of similar volume (Neuman and Witherspoon, 1972). For the confining-unit material in the Oxnard basin, approximately $80 \mathrm{mi}$ southeast of the city of Lompoc, Neuman and Witherspoon (1972) reported storage coefficients as high as 0.012 (a thickness of $50 \mathrm{ft}$ is assumed for the confining-unit materials). In this area of the Lompoc plain, the average thickness of clay lenses is about $24 \mathrm{ft}$ (table 14). 
Table 14. Estimated and model-calibrated storage-coefficient values

[Model layer: Layers 2 and 3 represent middle and main zones of upper aquifer, respectively. Model area: See figure 2 for Lompoc plain subdivision boundaries. Average thickness: Average composite thickness of clay, sand, or gravel zones determined from lithologic and geophysical data. Range of values of calculated aquifer storage coefficient: Calculated using average to low values for compressibility of clay, sand, and gravel. Model-calibrated storage coefficient: See Figure 25 for areal distribution of model storage coefficient for layers 1-4. Values are rounded. $\mathrm{ft}$, foot]

\begin{tabular}{|c|c|c|c|c|c|c|c|}
\hline \multirow[t]{2}{*}{$\begin{array}{l}\text { Model } \\
\text { layer }\end{array}$} & \multirow[t]{2}{*}{ Model area } & \multicolumn{3}{|c|}{$\begin{array}{l}\text { Average thickness } \\
\text { (ft) }\end{array}$} & \multirow{2}{*}{$\begin{array}{l}\text { Average } \\
\text { aquifer } \\
\text { thickness } \\
\text { (ft) }\end{array}$} & \multirow{2}{*}{$\begin{array}{l}\text { Range of } \\
\text { values of } \\
\text { calculated } \\
\text { aquifer storage } \\
\text { coefficient } \\
\text { (dimensionless) }\end{array}$} & \multirow{2}{*}{$\begin{array}{l}\text { Model calibrated } \\
\text { storage } \\
\text { coefficient } \\
\text { (dimensionless) }\end{array}$} \\
\hline & & $\overline{\text { Clay }}$ & Sand & $\overline{\text { Gravel }}$ & & & \\
\hline 2 & $\begin{array}{l}\text { Western, central, and northeastern } \\
\text { plains }\end{array}$ & 24 & 14 & 2 & 40 & $0.008-0.0008$ & 0.01 \\
\hline 2 & East river and coastal areas & 12 & 24 & 4 & 40 & $0.004-0.0004$ & .0004 \\
\hline 2 & $\begin{array}{l}\text { Southern plain and southern part } \\
\text { of western plain }\end{array}$ & 4 & 16 & 20 & 40 & $0.002-0.0002$ & .0004 \\
\hline 2 & $\begin{array}{l}\text { Eastern plain and alluvium beneath } \\
\text { Santa Ynez River }\end{array}$ & 0 & 35 & 5 & 40 & $0.001-0.0001$ & .0001 \\
\hline 3 & $\begin{array}{l}\text { Eastern, northeastern, central, } \\
\text { western, and northern plains }\end{array}$ & 0 & 54 & 31 & 85 & $0.002-0.0002$ & .0002 \\
\hline
\end{tabular}

\section{Transport-Model Construction}

The two-dimensional finite-element model SUTRA (Voss, 1984) was used to simulate solute transport in the main zone of the upper aquifer. SUTRA may be used for cross-sectional and areal modeling of saturated or unsaturated ground-water flow and the transport of solute. The model uses finite elements with Galerkin integration for spatial discretization and finite differences for temporal discretization. A heterogeneous, anisotropic (with any orientation of the principal conductivity directions) aquifer may be modeled. SUTRA can model sorption, production, and decay of solute (features not used in this study) as well as solute diffusion in ground water and its longitudinal and transverse dispersion.

In the original SUTRA code, the duration of the initial model time step remains constant or may be increased or decreased by some fixed factor up to a maximum value. Because the duration of wet and dry periods varied from year to year in the Lompoc area, the SUTRA code was modified to allow variable time steps. In addition, the original SUTRA code allows only one fluid source or sink per node. In order to simulate the main zone, SUTRA was modified to allow multiple sources or sinks. The specific changes made to the SUTRA code are discussed in the "Supplemental Data" section of this report.

In order to numerically simulate solute transport in the main zone, it was necessary to (1) divide the main zone into a grid, (2) determine the inflows and outflows to or from the main zone, (3) determine the dissolved-solids concentration of inflows to the main zone, and (4) estimate the aquifer properties. 


\section{Model Grid}

In order to assure numerical stability, area is more finely discretized in the solute-transport model than it is in the flow model. Voss (1984, p. 229-235) cautions that spatial discretization must be sufficiently fine to assure the accuracy and stability of transport models, and suggests that

$$
\Delta L \leq 4 \alpha_{L},
$$

where $\alpha_{\mathrm{L}}$ is longitudinal dispersivity and $\Delta \mathrm{L}$ is the distance between element sides along a streamline of flow. The spatial discretization of the flow model, square cells with 1,320-foot sides, would constrain calibrations of the solute-transport model to $\alpha_{\mathrm{L}}$ greater than $330 \mathrm{ft}$, which is larger than many reported values of longitudinal dispersivity. Therefore, prior to calibrating the solute-transport model, the length of the element sides were reduced to $660 \mathrm{ft}$, permitting calibration down to values of $\alpha_{\mathrm{L}}$ greater than $165 \mathrm{ft}$. The solute-transport model grid is presented in figure 26.

The finer spatial discretization of the solute-transport model, relative to the flow model, complicated the process of using input and output of the flow model as input to the solute-transport model. Whereas input and output data for the flow model are for rectangular, block-centered, finitedifference cells (McDonald and Harbaugh, 1988), the input and output data for solute-transport model are for comparatively finer spaced nodes within a finite-element mesh. Furthermore, the models work differently in that the hydraulic parameters for the flow model are specified at the center of a cell; whereas the same parameters for the solute-transport model are specified at the corner of a cell (fig. 26).

\section{Inflows and Outflows}

Fluid inflow (sources) to or outflow (sinks) from the main zone occurs to or from (1) the overlying middle zone (layer 2 in the flow model), (2) the underlying lower aquifer (layer 4 in the flow model) and the consolidated rocks that are in direct contact with the main zone in the northwestern, western, and coastal plains , (3) the adjacent aquifer units that are in lateral contact with the main zone, including the Narrows and the Pacific Ocean, and as pumpage.

Vertical leakage from the middle zone, the underlying lower aquifer, and the consolidated rocks to the main zone determined by the flow model introduced to the solute-transport model as fluid sources (fluid source or sink QIN2 and QIN3, respectively, in input unit 56 to BCTIME; see Supplemental Data section). The area covered by each flow-model cell corresponds to nine SUTRA nodes. Onequarter of the flux to or from the main zone owing to leakage from or to a cell in the second or the fourth layer of the flow model is assigned to the node at the center of the cell. One-eighth of this flux is assigned to each of the four nodes at the center of the edges of the cell. One-sixteenth of this flux is assigned to each of the four nodes at the corners of the cell (fig. 26B). 


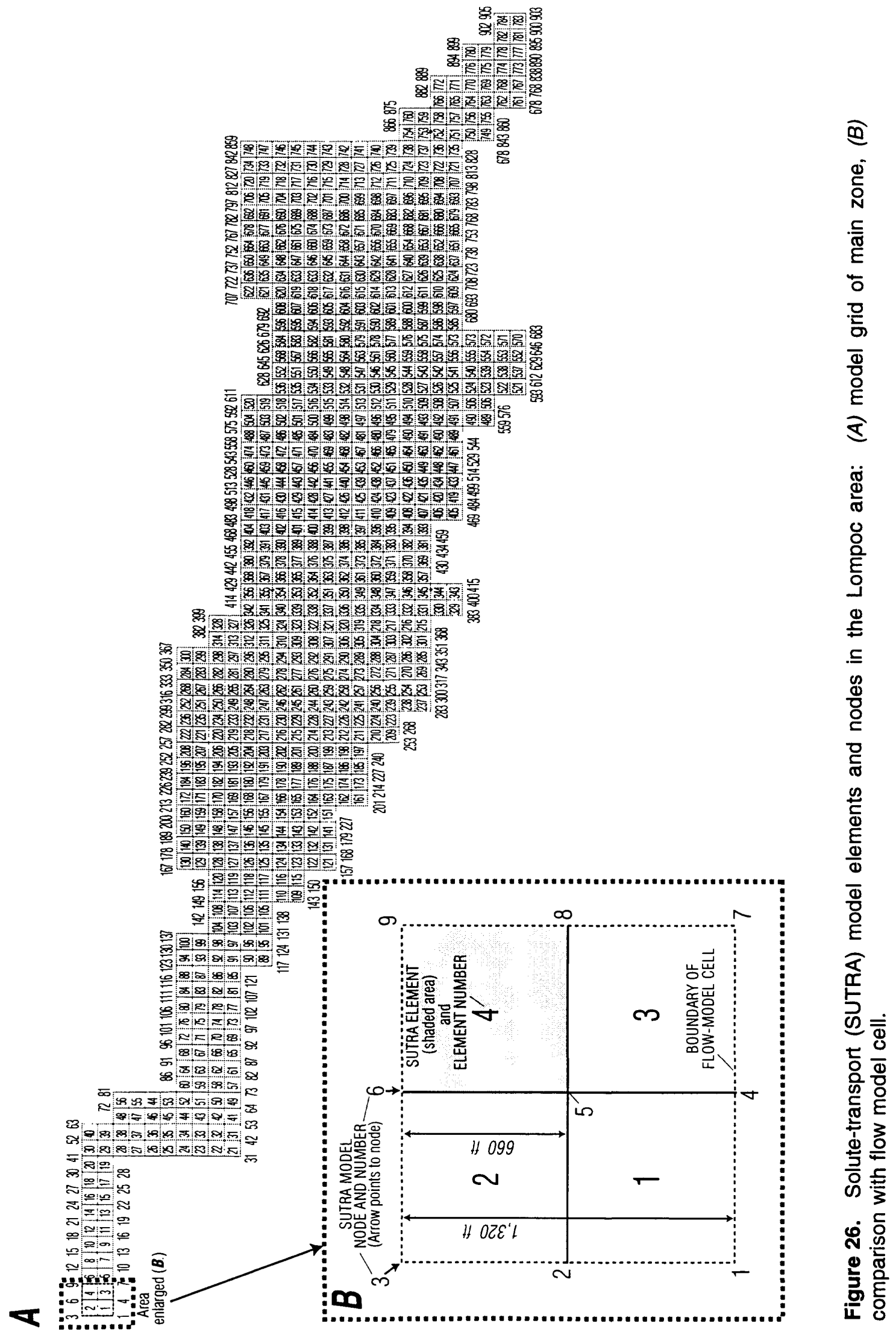


The inflows or outflows determined by the flow model for the lateral boundaries of the main zone and adjacent units at the end of each stress period are injected or withdrawn from corresponding nodes along the boundary of the main zone of the solute-transport model (fluid source or sink QIN1 in input unit 56 to BCTIME; see Supplemental Data section)—except for the boundary adjacent to the Pacific Ocean. The edge of a flow-model cell corresponds to three SUTRA nodes. One-half of the flux to or from the main zone owing to inflow or outflow from an adjoining cell in layer 3 or from the Narrows immediately adjacent but outside the main zone is assigned to the node at the center of the edge. Onequarter of this flux is assigned to each of the two nodes at the ends of the edge of the cell. (fig. $26 \mathrm{~B}$ ).

Flow between the main zone and Pacific Ocean, was modeled as a general-head boundary (previously discussed in the "Flow-Model Construction" section). The same boundary conductance was used for both the flow and solute-transport models.

Ground-water pumpage simulated as occurring from the main zone in the flow model is simulated in the solute-transport model (fig. 19; table 9). Pumpage from a flow-model cell is assigned to the solute-transport model node corresponding to the center of that flow-model cell (fluid source or sink QIN4 in input unit 56 to BCTIME; see Supplemental Data section).

\section{Dissolved-Solids Concentration of Inflows}

The solute-transport model requires the user to input values of dissolved-solids concentration for inflows to the main zone (middle zone, lower aquifer, consolidated rocks, and lateral boundaries). For the eastern plain, adjacent to the Santa Ynez River near the Narrows gaging station (fig. 5), dissolved-solids concentrations for the middle zone were varied annually in the solute-transport model (fig. 27). Each calendar year simulated in the flow and solute-transport models was divided into a wet and a dry period of varying duration (table 6). Variations in dissolved-solids concentration in this area correspond to measured changes in discharge and the dissolved-solids concentration of streamflow. Instantaneous-discharge and dissolved-solids concentration data collected at the Narrows gaging station during 1978-88 indicate that the dissolved-solids concentration of streamflow decreases with increased discharge (Bright and others, 1992, fig. 17). The data presented by Bright and others (1992, fig. 17) indicate that low flows (less than $10 \mathrm{ft}^{3} / \mathrm{s}$ ) typically have dissolved-solids concentrations of 800 to $1,300 \mathrm{mg} / \mathrm{L}$ and high flows (greater than $10 \mathrm{ft}^{3} / \mathrm{s}$ ) have dissolved-solids concentrations of 350 to 800 $\mathrm{mg} / \mathrm{L}$. To approximate the observed data, a dissolved-solids concentration of $800 \mathrm{mg} / \mathrm{L}$ was input for the Santa Ynez River nodes near the Narrows gaging station for wet stress periods, and 1,300 $\mathrm{mg} / \mathrm{L}$ was input for dry stress periods.

A dissolved-solids, concentration of $830 \mathrm{mg} / \mathrm{L}$ was input for the Santa Ynez River near the Narrows gaging station for the simulation of steady-state conditions. This value represents the flow weighted average of the 1941-88 wet and dry stress periods. During the period 1941-88 each wet stress period consisted of 148 days with an assumed dissolved-solids concentration of $800 \mathrm{mg} / \mathrm{L}$ and each dry stress period consisted of 217 days with an assumed dissolved-solids concentration of 1,300 $\mathrm{mg} / \mathrm{L}$.

For the remaining areas of the middle zone and the lateral fluxes along the boundary of the main zone, two distributions of dissolved-solids concentrations were used in the transport model to simulate the years 1941-46 and 1947-88. The first distribution (1941-46) of dissolved-solids concentration 

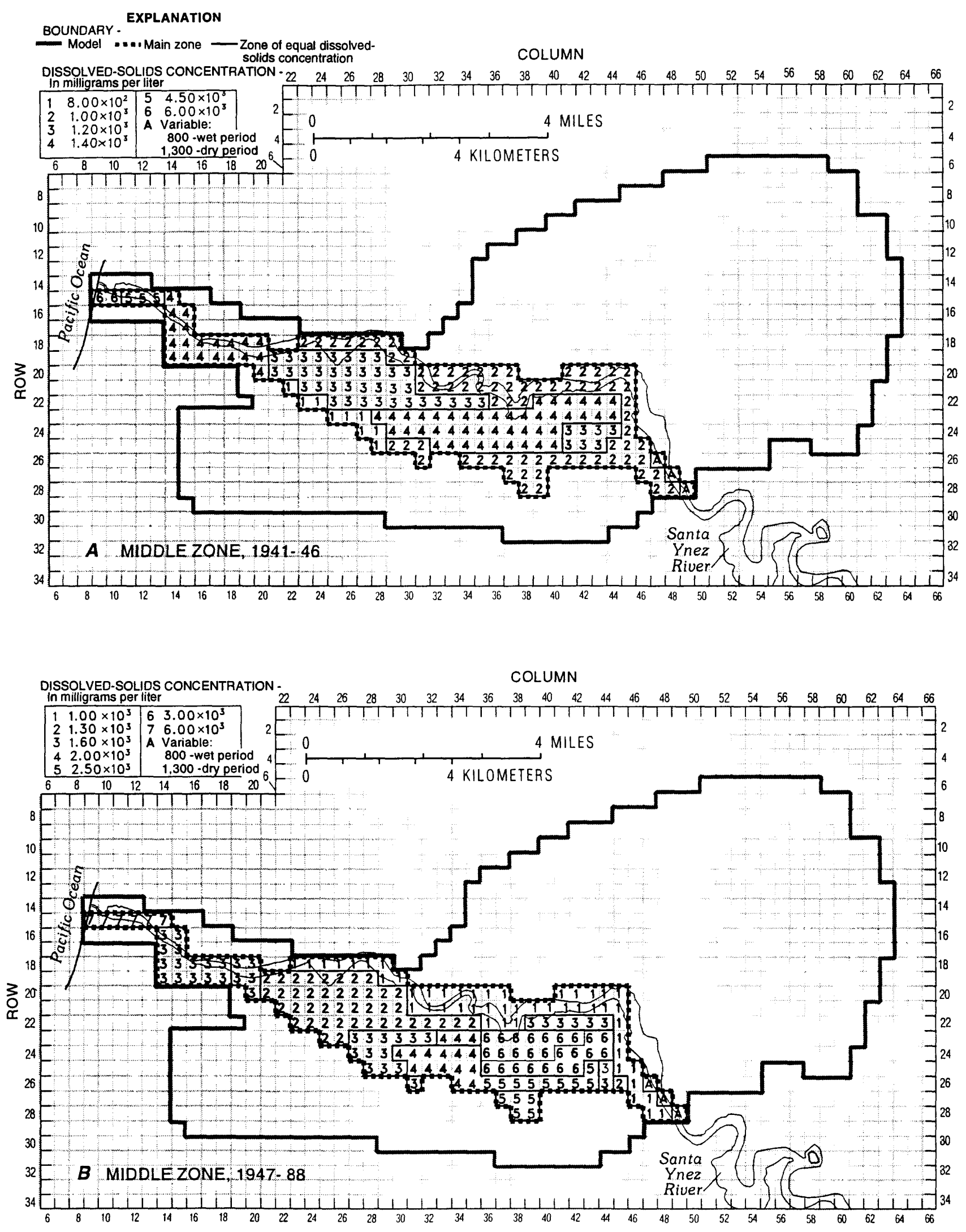

Figure 27. Areal distribution of dissolved-solids concentration for the solute-transport model in the Lompoc area: (A) middle zone, 1941-46; (B) middle zone, 1947-88; (C) lower aquifer, 1941-88; (D) lateral flow to main zone of upper aquifer,1941-46; (E) lateral flow to main zone of upper aquifer, 1947-88. 

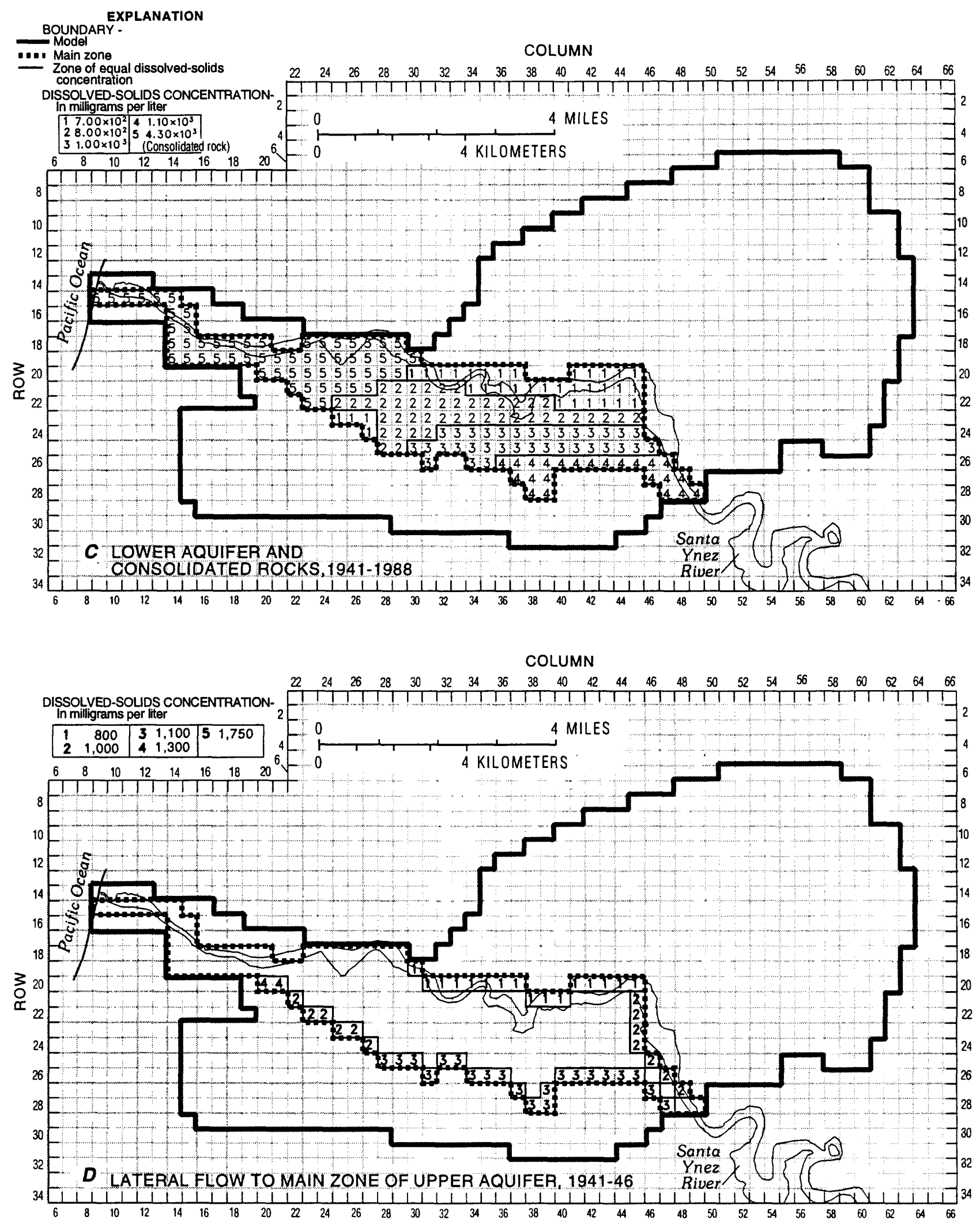

Figure 27.-Continued. 


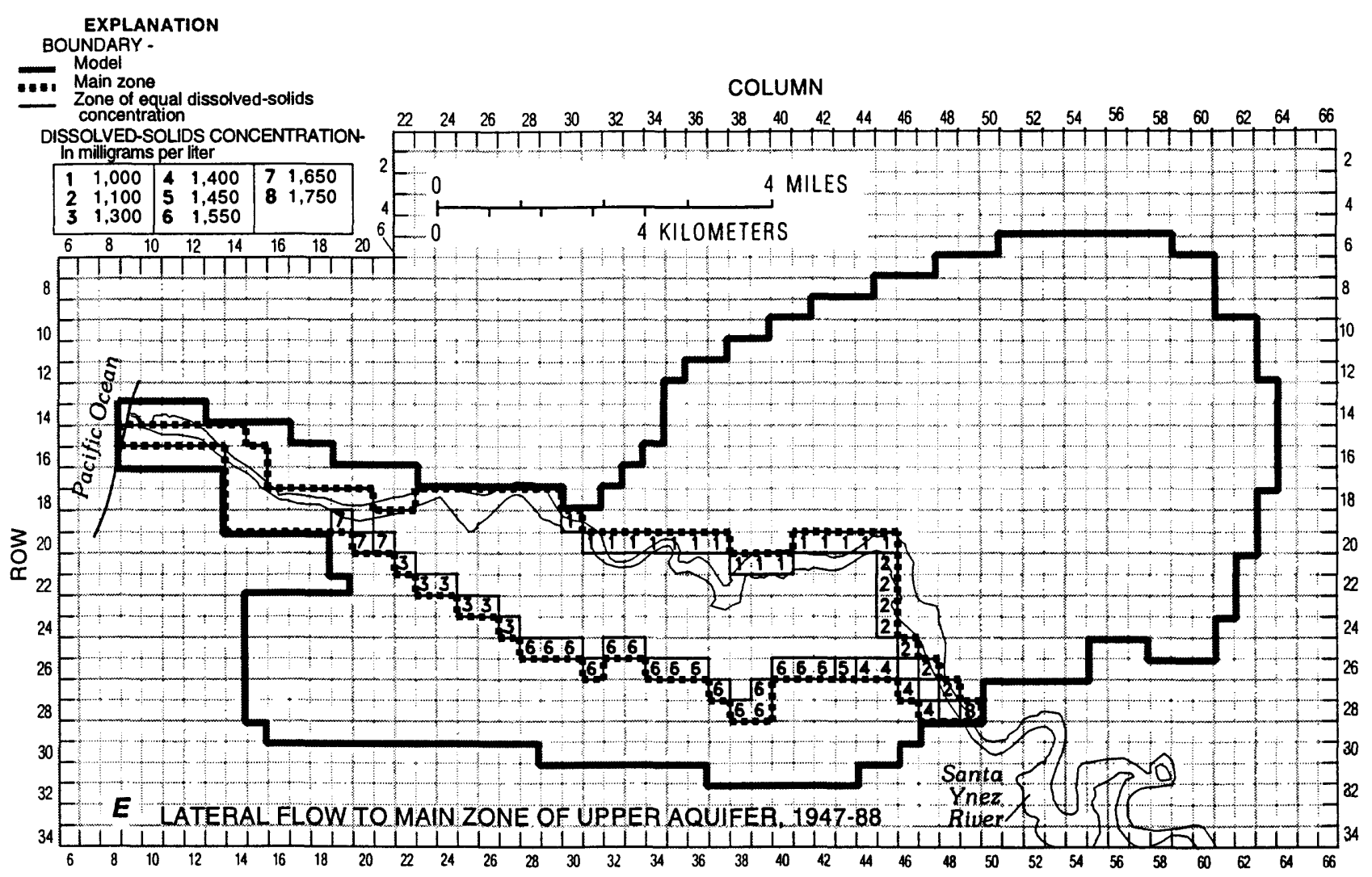

Figure 27.-Continued.

representing the middle zone and lateral fluxes is based primarily on water-quality data presented by Wilson (1959, p. 110-116), and on the extrapolation of dissolved-solids concentrations to areas lacking water-quality data. Extrapolated concentrations for the middle zone and lateral fluxes are based on dissolved-solids concentrations presented by Evenson (1964), and by Miller (1976), Berenbrock (1988), and Bright and others (1992).

The second distribution of dissolved-solids concentration for the middle zone and the lateral boundaries is based on water-quality data presented by Bright and others (1992, fig. 12). This distribution remained constant for the period $1947-88$ in the transient model. Historical water-quality data for the middle zone generally were not available prior to 1987 . Relatively low dissolved-solids concentrations during 1987-88 suggest that only slight changes have occurred in the water quality of the middle zone in most areas. In the northeastern plain, however, considerably higher concentrations indicated that leaching of water from the shallow zone probably had degraded the water quality of the middle zone. For modeling purposes, it was assumed that the initial migration of poor-quality water from the shallow zone to the middle zone probably occurred in 1947, when agricultural pumpage nearly doubled throughout the plain as a result of drought conditions. Water-quality data for the middle zone, however, are not available to substantiate this assumption. Sparse water-quality data for areas adjacent to the main zone beneath the southern plain indicate that dissolved-solids concentrations generally increased during 1941-53 (Wilson, 1959, table 9). As was assumed for the middle zone, it was assumed in this study that the dissolved-solids concentration of lateral flow to the main zone increased in 1947 and then remained constant during 1947-88. 
A value of $1,300 \mathrm{mg} / \mathrm{L}$ was used in the solute-transport model to simulate the dissolved-solids concentration of underflow through river-channel deposits at the Narrows. This value equals the observed dissolved-solids concentration of base flow in the river channel at the Narrows in 1987 (U.S. Geological Survey data files, San Diego, California). Because water-quality data for base flow in the Santa Ynez River are scant, the dissolved-solids concentration of $1,300 \mathrm{mg} / \mathrm{L}$ was applied to nodes at the southeastern boundary of the transport model and used for each stress period in the steady-state and transient calibrations (fig. 27).

Because the dissolved-solids concentration in the lower aquifer probably has not changed significantly during 1941-88, (Bright and others, 1992), only one distribution of dissolved-solids concentration was used to represent the lower aquifer for both the steady-state and transient simulation (fig. 27). A value of $4,300 \mathrm{mg} / \mathrm{L}$ was used in the transport model to simulate the dissolved-solids concentration of leakage from the underlying consolidated rocks to the main zone in the northwestern, western, and coastal plains (fig. 27). This value is the average of dissolved-solids concentrations of samples from monitor well $7 \mathrm{~N} / 35 \mathrm{~W}-23 \mathrm{E} 5$, which is perforated in the consolidated rocks in the northwestern plain.

A value of $34,500 \mathrm{mg} / \mathrm{L}$ was used in the transport model to simulate the dissolved-solids concentration of underflow from the Pacific Ocean. The model does not simulate the density of the saltwater.

\section{Aquifer Propertles}

The hydraulic conductivity (transmissivity of layer 3 [fig. 22] divided by the thickness of the main zone) and storage coefficient (fig. 25) used in the flow model were transferred to the solute-transport model. Additional aquifer properties needed for the solute-transport model are aquifer thickness, porosity, and dispersivity. Aquifer thickness, storage properties, and porosity are entered at every node, and hydraulic conductivity and dispersivity are entered at every element. In order to obtain SUTRA results in terms of hydraulic head and $\mathrm{mg} / \mathrm{L}$, the following was specified in the SUTRA input files: fluid density $(\rho)=1.0$, no change in fluid density with concentration $(\delta \rho=0)$, fluid viscosity $(\mu)=1.0$, and gravitational acceleration $(\mathrm{g})=0.0$ (Voss, 1984).

The transmissivity of the main zone was simulated as a constant value of $16,000 \mathrm{ft}^{2} / \mathrm{d}$ in the flow model, and the thickness of the main zone was assumed to be a constant value of $85 \mathrm{ft}$; therefore, the hydraulic conductivity of the main zone was simulated as a constant value of $188 \mathrm{ft} / \mathrm{d}$. The hydraulic conductivity was considered isotopic and is entered as $188 \mathrm{ft} / \mathrm{d}$ for both the maximum and minimum permeability values in the element wide dataset.

The storage coefficient $(S)$ simulated for the main zone in the flow model $(0.0002)$ was converted to a specific storage $\left(\mathrm{S}_{\mathrm{s}}\right)$ by dividing by the thickness of the main zone $(85 \mathrm{ft})$. SUTRA requires that the specific storage be input as a function of its components: matrix compressibility $\left(\alpha_{m}\right)$, fluid compressibility $\left(B_{f}\right)$, and porosity $(n)$; where $S_{s}=(1-n) \alpha_{m}+n B_{f}$ (Voss, 1984). For simplicity in data input entry, the matrix compressibility was set equal to $0.0 \mathrm{ft}^{-1}$ and fluid compressibility was derived by dividing specific storage by porosity. The porosity was determined to be 0.2 on the basis of reported values for sand and gravel aquifers summarized by Mercer and others (1982). Therefore, a value of $1.18 \times 10^{-6} \mathrm{ft}^{-1}$ was entered for fluid compressibility in the fluid properties input data set. 
Values for longitudinal $\left(\alpha_{L}\right)$ and transverse $\left(\alpha_{T}\right)$ dispersivity were estimated from a summary of reported values presented by Gelhar and others (1992). They demonstrate a strong positive correlation between reported values for $\left(\alpha_{L}\right)$ and scale at scales less than 1,640 ft $(500 \mathrm{~m})$. Values of $\left(\alpha_{L}\right)$ for studies of scale greater than $1640 \mathrm{ft}$, rated by Gelhlar and others (1992) as being of relatively low reliability, are scattered over approximately two orders of magnitude [33 ft $(10 \mathrm{~m})$ to $3,280 \mathrm{ft}(1,000$ $\mathrm{m})]$ and are less sensitive to scale. At a scale of $65,600 \mathrm{ft}(20,000 \mathrm{~m})$, the approximate length of the solute-transport model in this study $(52,800 \mathrm{ft})$, reported values of $\left(\alpha_{\mathrm{L}}\right)$ range from $131 \mathrm{ft}(40 \mathrm{~m})$ to $3,280 \mathrm{ft}(1,000 \mathrm{~m})$ and average about $330 \mathrm{ft}(100 \mathrm{~m})$, which is the value selected for use in this study. Gelhar and others (1992) further demonstrate that the reported values of $\left(\alpha_{\mathrm{T}}\right)$ are generally about onethird the corresponding value of $\left(\alpha_{\mathrm{L}}\right)$ therefore, a value of $110 \mathrm{ft}(33 \mathrm{~m})$ was used for $\left(\alpha_{\mathrm{T}}\right)$ in this study.

\section{Calibration of Models}

Ground-water conditions during the period 1941-88 were used to calibrate the flow and solutetransport models to transient or time-dependent conditions. A steady-state simulation was made to provide initial conditions for the transient-state simulation. A steady-state flow condition exists when net recharge to the system equals net discharge from the system, and aquifer storage does not change with time. Similarly, a steady-state transport condition exists when solute mass to the system equals solute mass from the system, and the quality of water stored in the aquifer remains constant with time at all locations. A transient condition exists when aquifer recharge, discharge, and solute mass change with time, resulting in an increase or decrease in the quantity and quality of water stored in the aquifer.

Calibrating the flow model and solute-transport model in tandem constrains the models by allowing both simulated hydraulic heads and dissolved-solids concentrations to be used in the calibration process. The calibration of these models requires the iterative process of adjusting initial estimates of certain aquifer properties and recharge and discharge to obtain the best match between model-simulated and measured hydraulic heads, dissolved-solids concentrations, and selected waterbudget items. The initial estimates are adjusted within reasonable limits that are based on the geologic, hydrologic, and water-quality properties of the basin and the degree of confidence placed on the original data estimates. When a satisfactory match was obtained between the measured and modeled heads, the inflows and outflows determined by the flow model for the lateral boundaries of the main zone and adjacent units were used as input into the solute-transport model. If a satisfactory match between measured and simulated dissolved-solids concentrations could not be obtained, the calibration process was repeated beginning with the steady-state flow model. This iterative process was repeated until modeled hydraulic head, dissolved-solids concentrations, and water-budget items reasonably matched measured or estimated values, and calculated fluid and solute fluxes within the aquifer system were reasonable.

\section{Steady-State Simulation}

A steady-state simulation was made to provide initial condition for the transient calibration. Steady-state hydraulic head and dissolved-solids concentration primarily are dependent on the recharge to and discharge from the ground-water system, the transmissivity of the aquifer system, vertical 
leakage between layers, and the dissolved-solids concentration of the recharge water. The steady-state simulation consisted of modifying (1) initial estimates of transmissivity, (2) the quantity and distribution of recharge, (3) vertical leakage between layers, (4) the hydraulic conductance of surface and subsurface drains in the shallow zone beneath the western plain, and (5) the distribution of dissolved-solids concentrations above and along the boundary of the main zone. Because hydraulic heads are constant under steady-state conditions, the storage component of the system is not part of the steady-state simulation.

For the steady-state simulation, long-term average (1941-88) recharge values were used for southern streams seepage and precipitation recharge (table 8). The 1941 rate was used for the irrigation return flow recharge (table 8). The average annual streamflow (1941-88) for the Santa Ynez River at Robinson Bridge $\left(115 \mathrm{ft}^{3} / \mathrm{s}\right)$ was specified for the farthest upstream reach of the streamflow-routing package. Pumpage was set equal to the 1941 rates (table 9). The dissolved-solids concentration for inflows to the main zone (middle zone, lower aquifer, and lateral boundaries) were specified as shown in figure 27A, C, and E. The dissolved-solids concentration of the model cells representing the Santa Ynez River near the narrows (indicated as variable on figure $27 \mathrm{~A}$ ) was set equal to $830 \mathrm{mg} / \mathrm{L}$.

Ground-water level measurements made during 1941 were used to determine if the steady-state simulation provided reasonable initial conditions for the subsequent transient simulation. Although pumping occurred during this period, there was little net decline of hydraulic heads in the shallow and main zones, and differences between total recharge and discharge were minimal (Upson and Thomasson, 1951, p. 160). Scant water-level data were collected in 1941 for the shallow and middle zones of the upper aquifer (layers 1 and 2, respectively). Data for the lower aquifer during this period were available only for the southern plain (layer 2), east river area (layer 3), and a part of the Lompoc upland near the eastern boundary of the model (layer 4). Hydraulic heads calculated for these layers were compared with the available 1941 measured water levels. Simulated heads differed from measured water levels by about $5 \mathrm{ft}$ for the shallow and middle zones and $10 \mathrm{ft}$ for the lower aquifer. Model-simulated hydraulic head for the main zone (layer 3) generally is within $5 \mathrm{ft}$ of the measured water levels (fig. 28). The measured water levels reflect conditions that occurred during the spring recharge period of 1941, one of the wettest years on record in Lompoc, whereas the simulated water levels are the result of long-term average (1941-88) recharge conditions.

The model-simulated dissolved-solids concentrations for the main zone generally are within 100 $\mathrm{mg} / \mathrm{L}$ of the 1941 measured values (fig. 29). For the western and northwestern plains, differences are greater than $100 \mathrm{mg} / \mathrm{L}$. In these areas the main zone overlies consolidated rocks containing water of high dissolved-solids concentration (greater than $4,300 \mathrm{mg} / \mathrm{L}$ ). The difference between measured and simulated concentrations is primarily the result of a limitation of the model. Because hydraulic-head data for the consolidated rocks are not available (see section on "Limitations of Models"), it was assumed in the flow model that head in the consolidated rocks equaled the head in the overlying main zone for the steady-state simulation. Therefore, no upward flux of poor-quality water from the consolidated rocks to the main zone occurs during the steady-state simulation. As a result, differences between observed and simulated dissolved-solids concentrations will be slightly larger in areas of the western and northwestern plains where observed concentrations in 1941 were relatively high (fig. 29). 


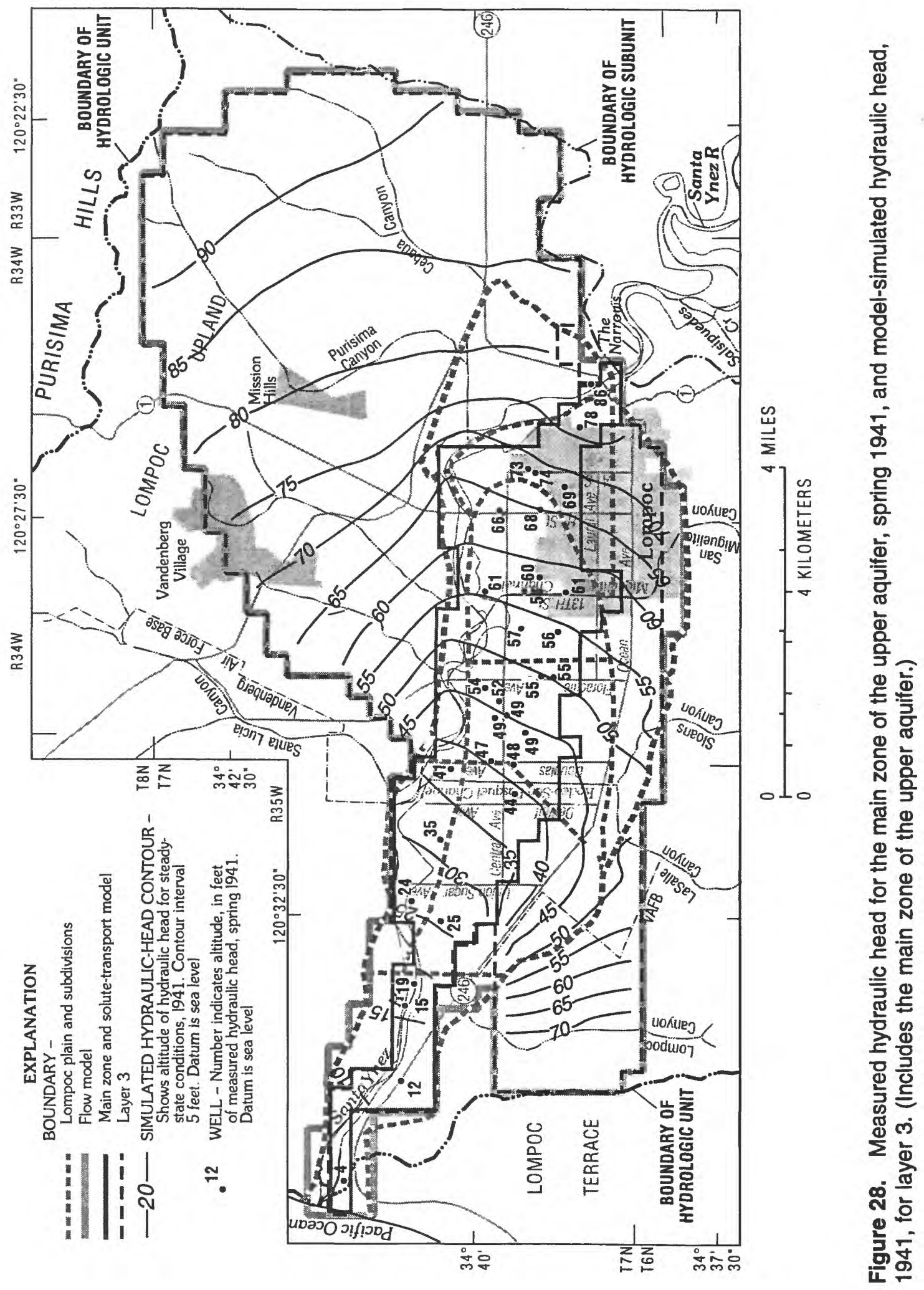




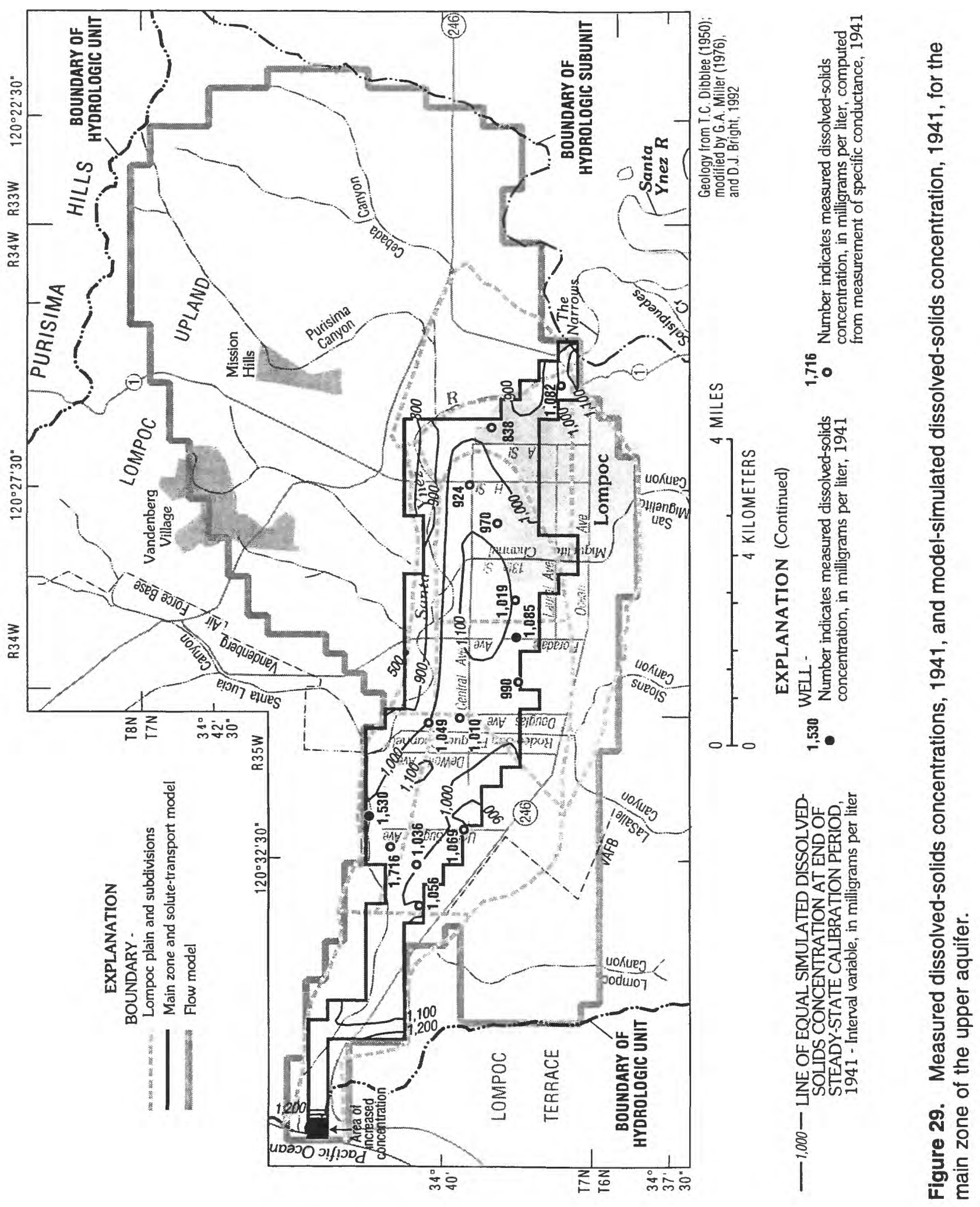




\section{Transient Simulation}

Ground-water conditions during the period 1941-88 were used to calibrate the models to transient or time-dependent conditions. Transient conditions in the Lompoc area are the result of stress on the system imposed by pumping from wells used for agricultural, municipal, and military supplies. As a result of the pumping, water levels have declined throughout the Lompoc area and dissolved-solids concentrations have increased in many parts of the Lompoc plain.

Changes in hydraulic head and dissolved-solids concentration are dependent on recharge and discharge, transmissivity, storage coefficient, leakance between layers, and dissolved-solids concentration in the bounding hydrologic units. For the transient calibration, the quantity of recharge from rainfall infiltration in the upland and terrace, hydraulic conductance of the interface between the upper aquifer and model drain cells and of the upper aquifer and the general-head boundary cells at the ocean, and the dissolved-solids concentration in the lower aquifer were presumed to be the same as those in the steady-state calibration and were not adjusted. Estimates of annual seepage loss along southern streams, rainfall infiltration, irrigation return flow, and pumpage were used in the model without modification (table 8). Therefore, the calibration procedure for transient conditions consisted of modifying the (1) distribution of pumpage, (2) maximum evapotranspiration rate, (3) initial estimates of storage coefficient, (4) vertical leakance between layers and across the general-head boundary beneath the westernmost part of the plain, and (5) estimates of dissolved-solids concentration for the middle zone and lateral flow to the main zone. These parameters were modified during the transient calibration until simulated hydraulic heads, fluxes, and simulated dissolved-solids concentrations reasonably matched measured values.

For this report, simulated heads and dissolved-solids concentrations were compared with measured long-term changes at selected wells and with measured values for 1988. In addition, simulated values of recharge and discharge were compared to previously estimated values (tables 2 and 3 ).

Hydraulic heads and dissolved-solids concentrations modeled during the steady-state simulation were used as initial conditions for the transient simulation. The period 1941-88 was modeled as 96 stress periods of variable length. Each calendar year was divided into a wet and dry period of varying duration (table 6). One timestep was used for each stress period in the flow model, and it was set equal to the number of days in corresponding wet or dry period. For each stress period in the solutetransport model, 10 timesteps of equal duration were used to calculate dissolved-solids concentrations. Model simulated discharge in the Santa Ynez River is compared with measured values at the Robinson Bridge, H Street, 13th Street, Pine Canyon, and barrier near Surf gage (fig. 30).

Model-simulated hydraulic heads were compared with measured long-term changes at 16 wells in the upper and lower aquifers (fig. 31). After calibration, the simulated and measured heads were generally within $5 \mathrm{ft}$ of each other (fig. 31). Larger differences, but generally less than $10 \mathrm{ft}$, between simulated and measured heads may be due, in part, to the generalized distribution of agricultural pumping used in the transient model and the constancy of simulated pumpage throughout the calendar year.

Available hydraulic-head data collected during 1987-88 at multiple-well sites in the eastern, central, and western plains (fig. 10) were used to calibrate vertical leakance between the shallow, middle, and main zones of the upper aquifer and between the main zone and the lower aquifer. The average measured hydraulic-head for early stress period is compared with the model calculated head 
anOOتS H
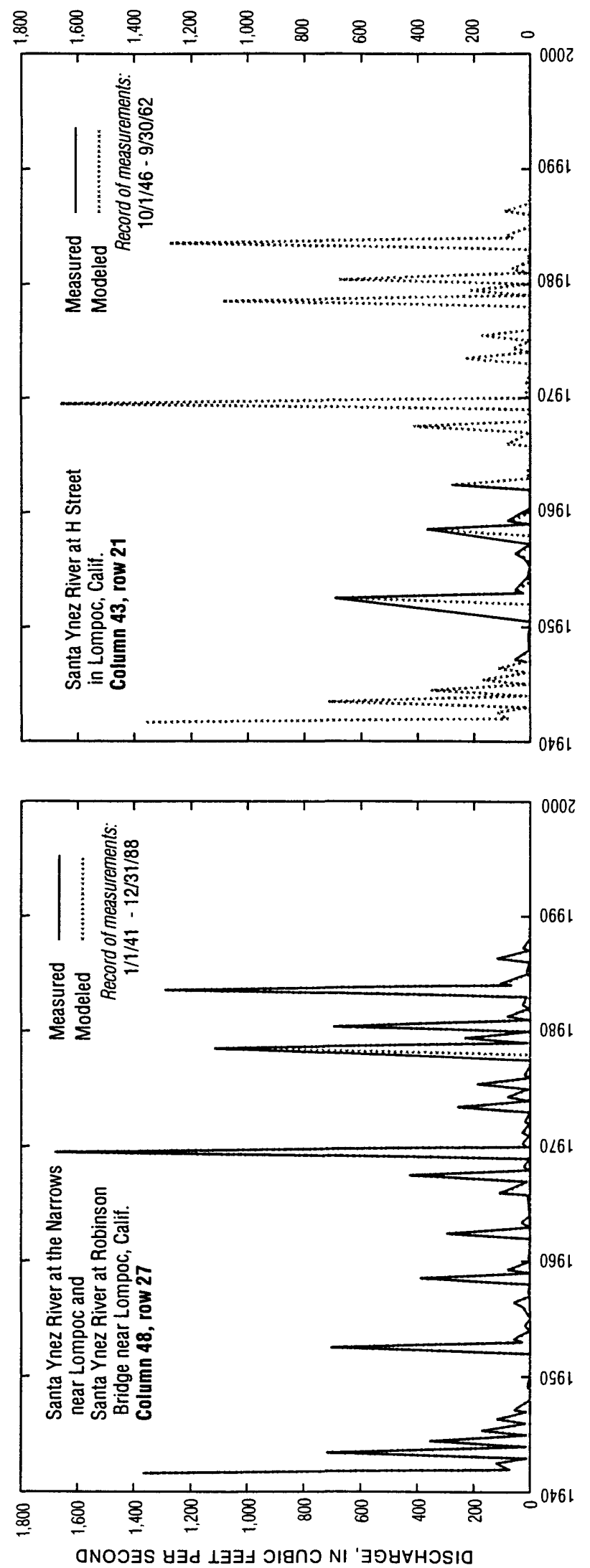

anOJ
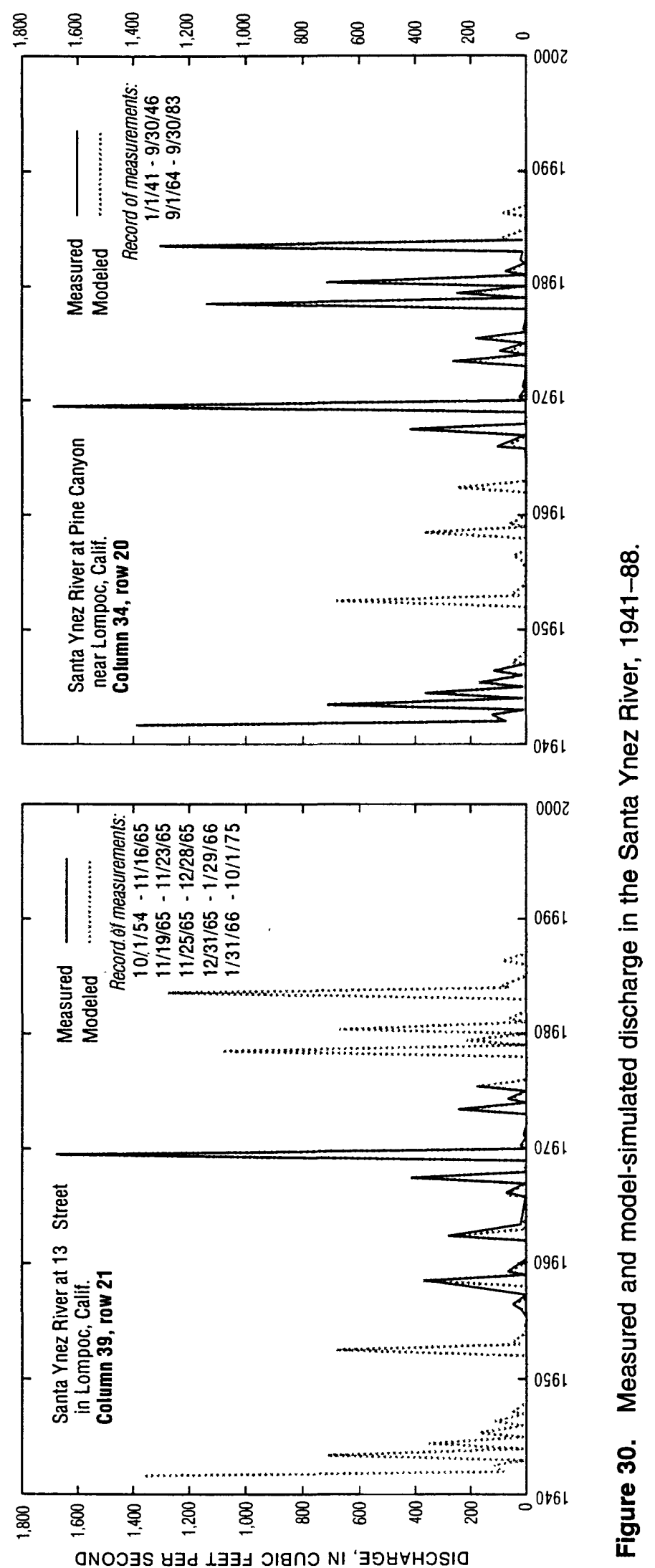


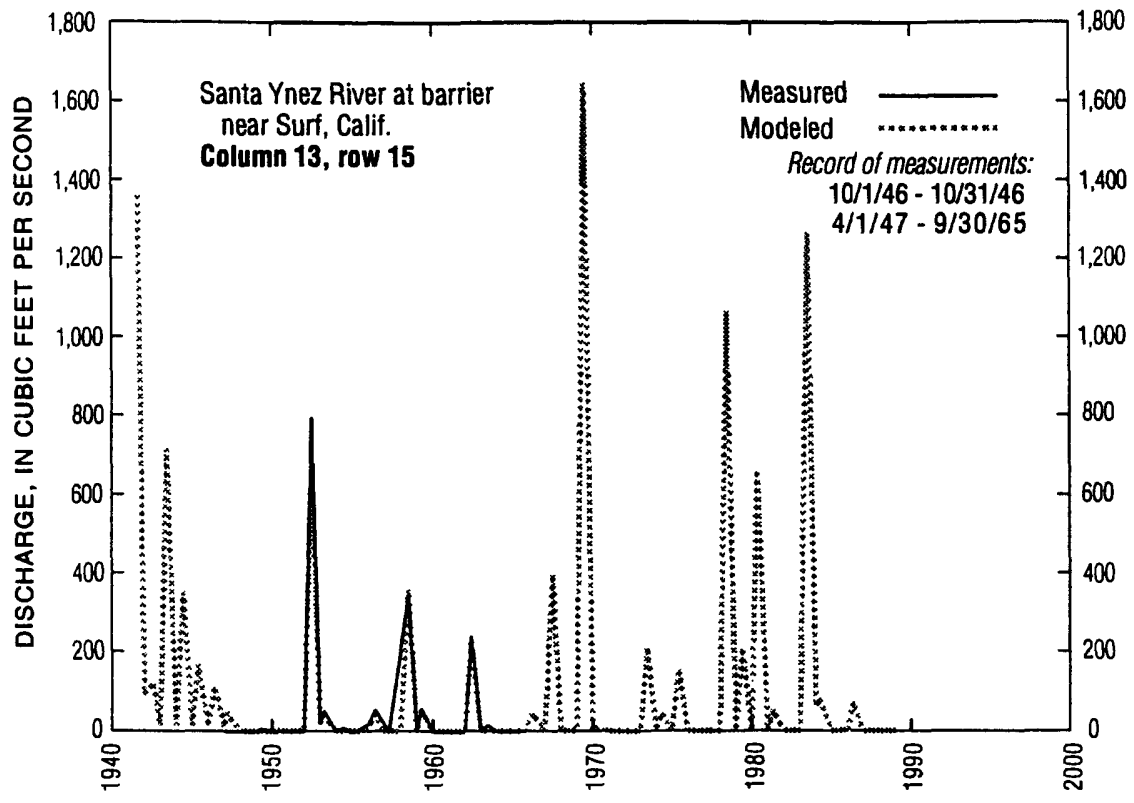

Figure 30.-Continued.

for each zone or aquifer at the different multiple-well sites in figure 32. The vertical leakage was calibrated by adjusting estimates of horizontal to vertical anisotropy. Higher values of horizontal to vertical anisotropy result in a greater hydraulic-head difference between layers and lower values result is a smaller difference. Model-simulated hydraulic-head differences between the different zones and between the main zone and the lower aquifer generally matched the trend of the measured differences. (fig 32).

Figure 33 shows a comparison between measured hydraulic heads in the main zone of the upper aquifer and the uplands and terrace areas of the lower aquifer in spring 1988 and those calculated by the model in layer 3 at the end of the transient-state calibration period (December 1988). Modeled and measured hydraulic heads generally differ by 5 to $10 \mathrm{ft}$ and show the same regional trends (fig. 33). The similarity between measured and modeled hydraulic heads during the transient-state calibration period indicates that the flow model approximates the hydraulic response of the ground-water system to pumping.

Model-simulated and long-term measured dissolved-solids concentrations (such long-term records of changes in concentration are called chemographs) were compared for 12 wells perforated in the main zone (fig. 34). The simulated values for dissolved-solids concentration generally correlate with trends shown in the chemographs. Simulated dissolved-solids concentrations are about $300 \mathrm{mg} / \mathrm{L}$ lower than measured concentrations for the initial years of the transient-state simulation in the northwestern plain (well $7 \mathrm{~N} / 35 \mathrm{~W}-24 \mathrm{~K} 2$ ) and western plain (well $7 \mathrm{~N} / 35 \mathrm{~W}-25 \mathrm{D} 1$ ). This difference is primarily the result of a limitation of the model. As described previously, no upward flux of poor-quality water from the consolidated rocks to the main zone occurs during the steady-state simulation. As a result, simulated dissolved-solids concentrations will be lower than measured values in areas of the western and northwestern plains in early years (fig. 34 ). 

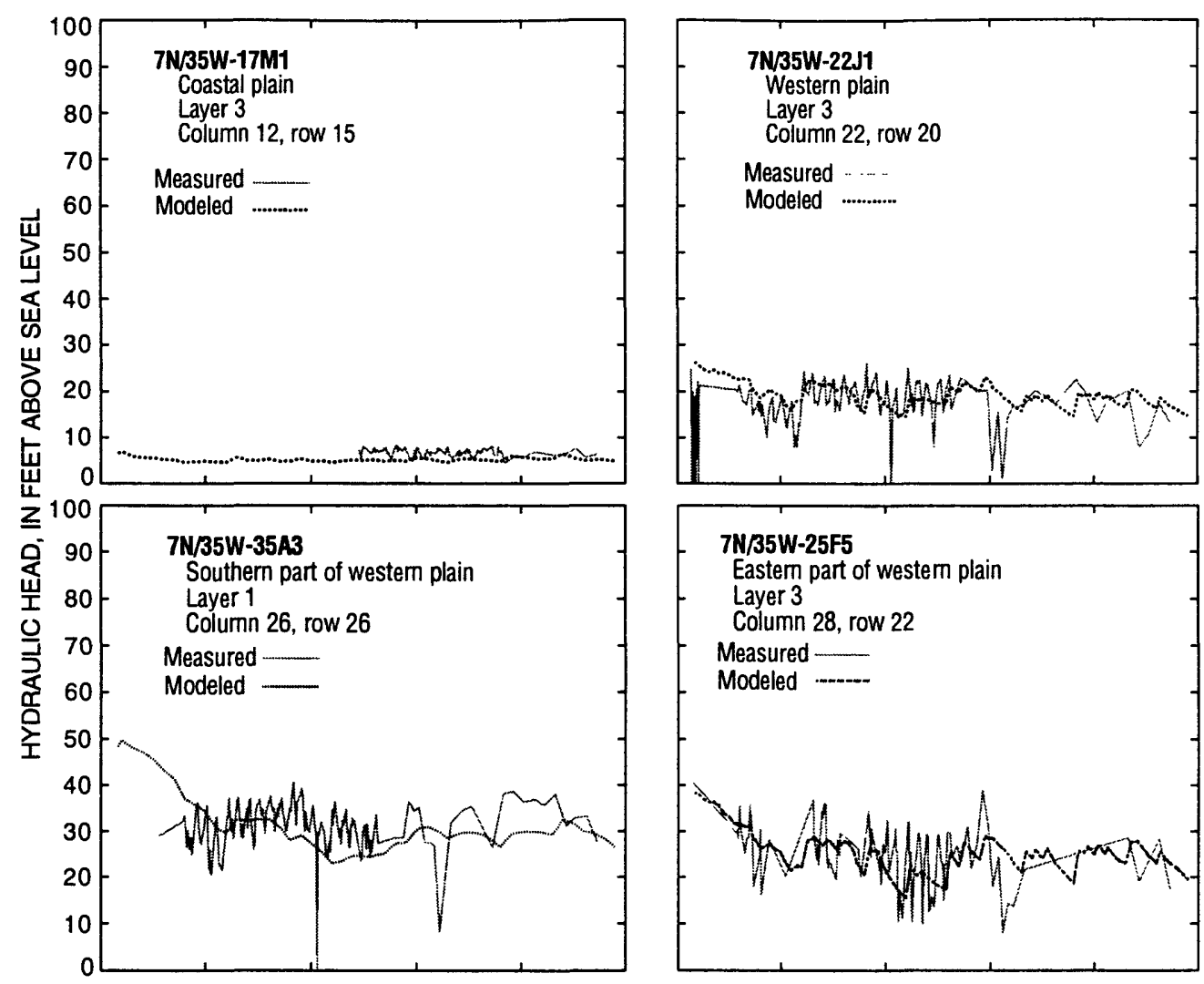

Column 22, row 20

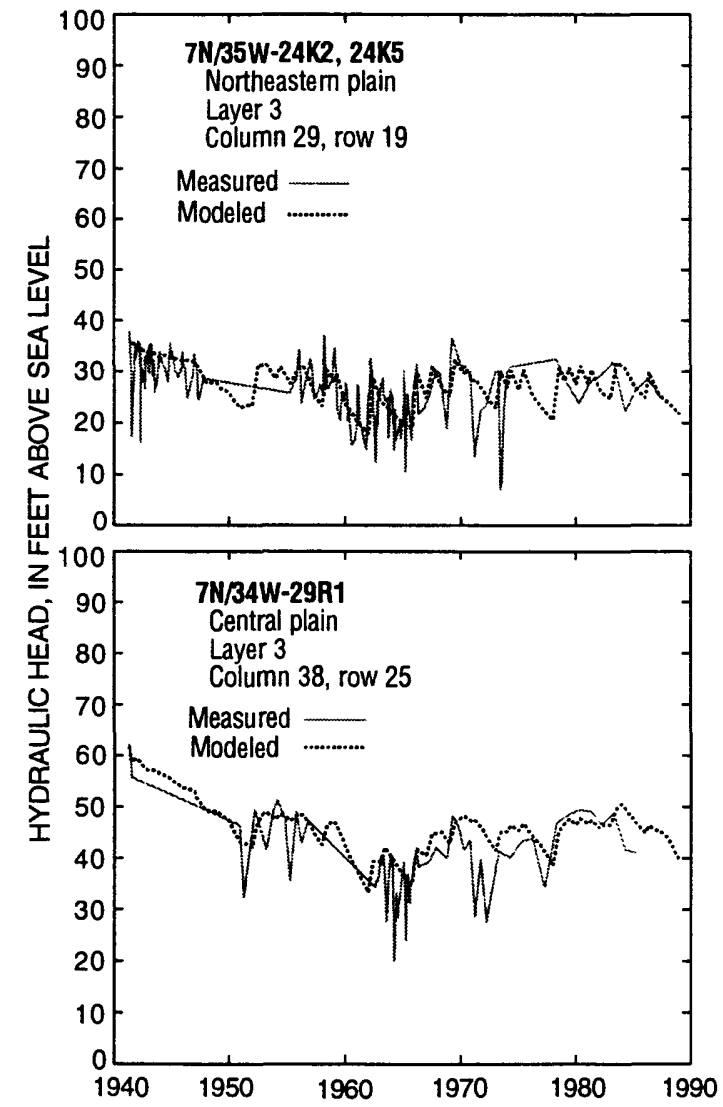

7N/35W-25F5

Eastem part of western plain

Layer 3

Column 28, row 22

Measured -

Modeled .......
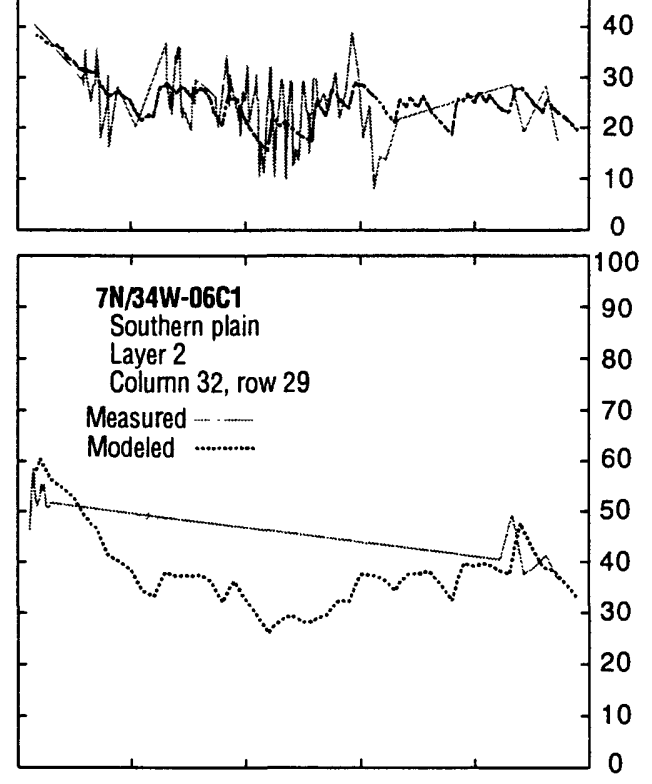

100

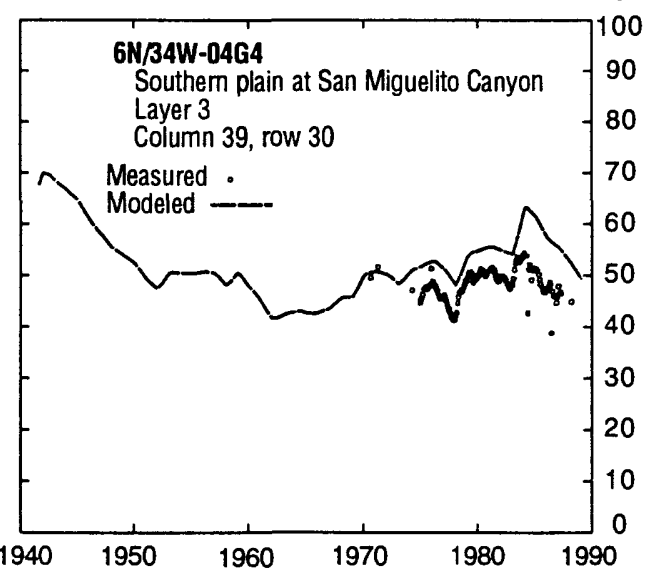

Figure 31. Measured and model-simulated hydraulic heads at selected wells in the upper and lower aquifers in the Lompoc area, 1941-88. (Location of wells shown in figure 2.) 

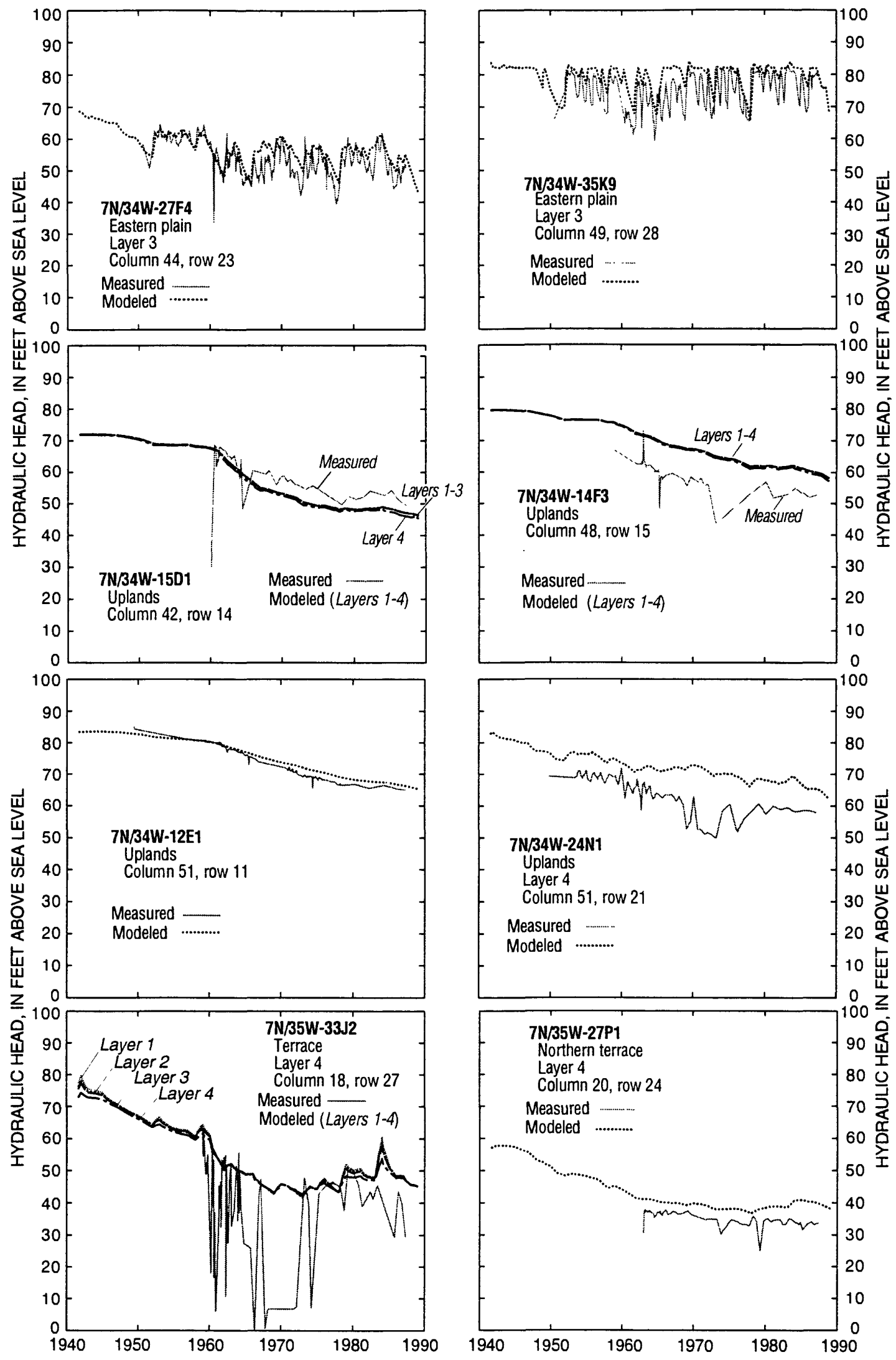

Figure 31.-Continued. 


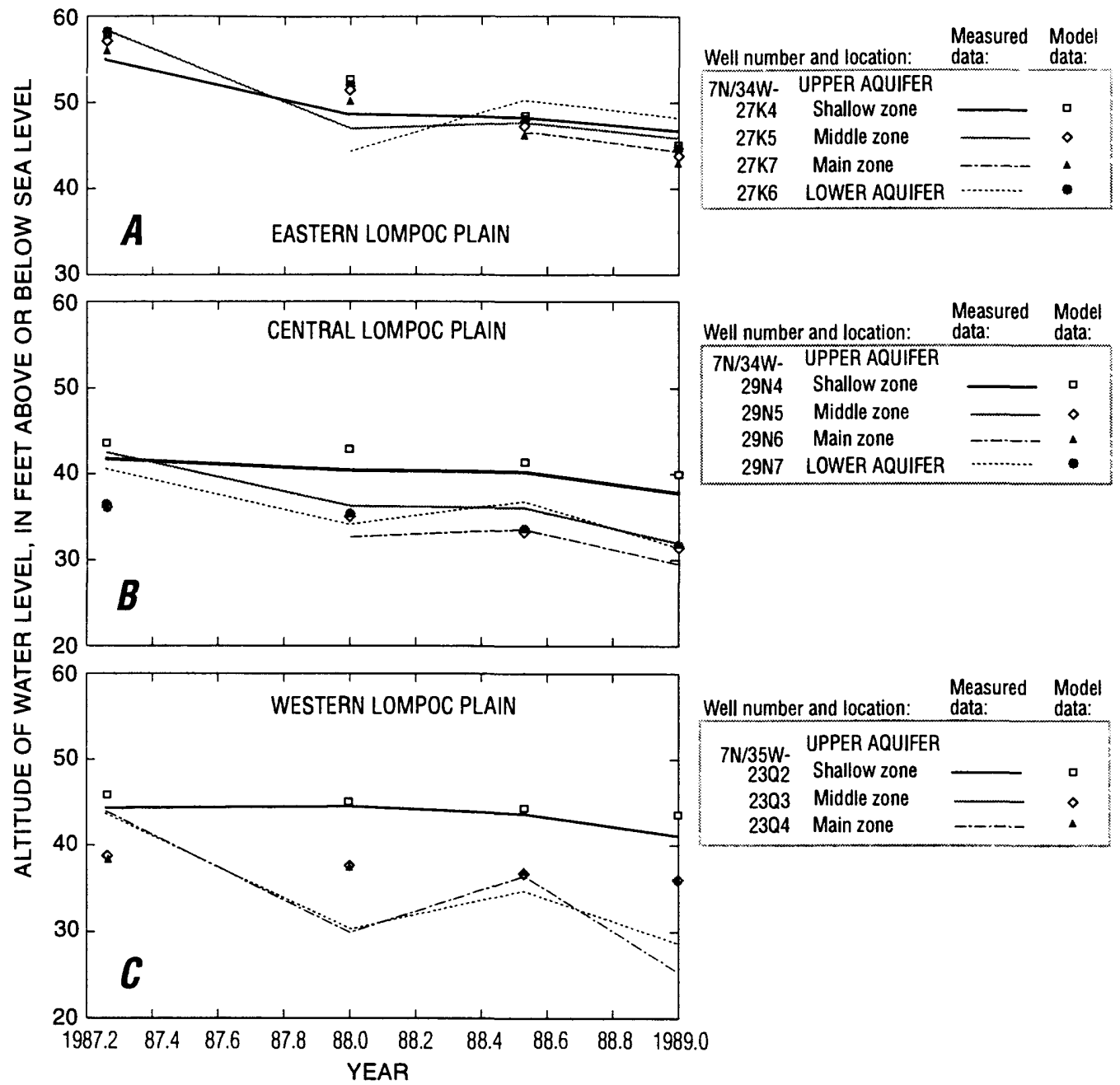

Figure 32. Average measured and model-simulated hydraulic heads at multiple-well sites in the eastern, central, and western plains in the Lompoc area, 1987-88.

Simulated dissolved-solids concentrations are more than $1,500 \mathrm{mg} / \mathrm{L}$ lower than measured values in the western part of the coastal plan (well 7N/35W-18J1). Bright and others (1992 p. 44) indicated that vertical migration of seawater from the overlying estuary was the source of the high dissolvedsolid concentration in this part of the main zone. Because the flow and solute-transport models do not model flow resulting from differences in fluid density, the effect of the overlying estuary on the dissolved-solids concentration of the main zone could not be simulated accurately. The inability of the solute-transport model to simulate this source of dissolved solids concentration has no effect on the dissolved-solids concentration simulated in the main zone east of the estuary, because the ground-water gradient is toward the coast throughout the simulation period (1941-88).

A comparison between average measured dissolved-solids concentrations, March 1987-December 1988, and model-simulated dissolved-solids concentrations for the main zone at the end of the transient-state calibration period (December 1988) is shown in figure 35. Simulated dissolved-solids concentrations generally are within $100-200 \mathrm{mg} / \mathrm{L}$ of measured values except for the western part of the coastal plain where simulated concentrations are more than $1,500 \mathrm{mg} / \mathrm{L}$ lower than measured 


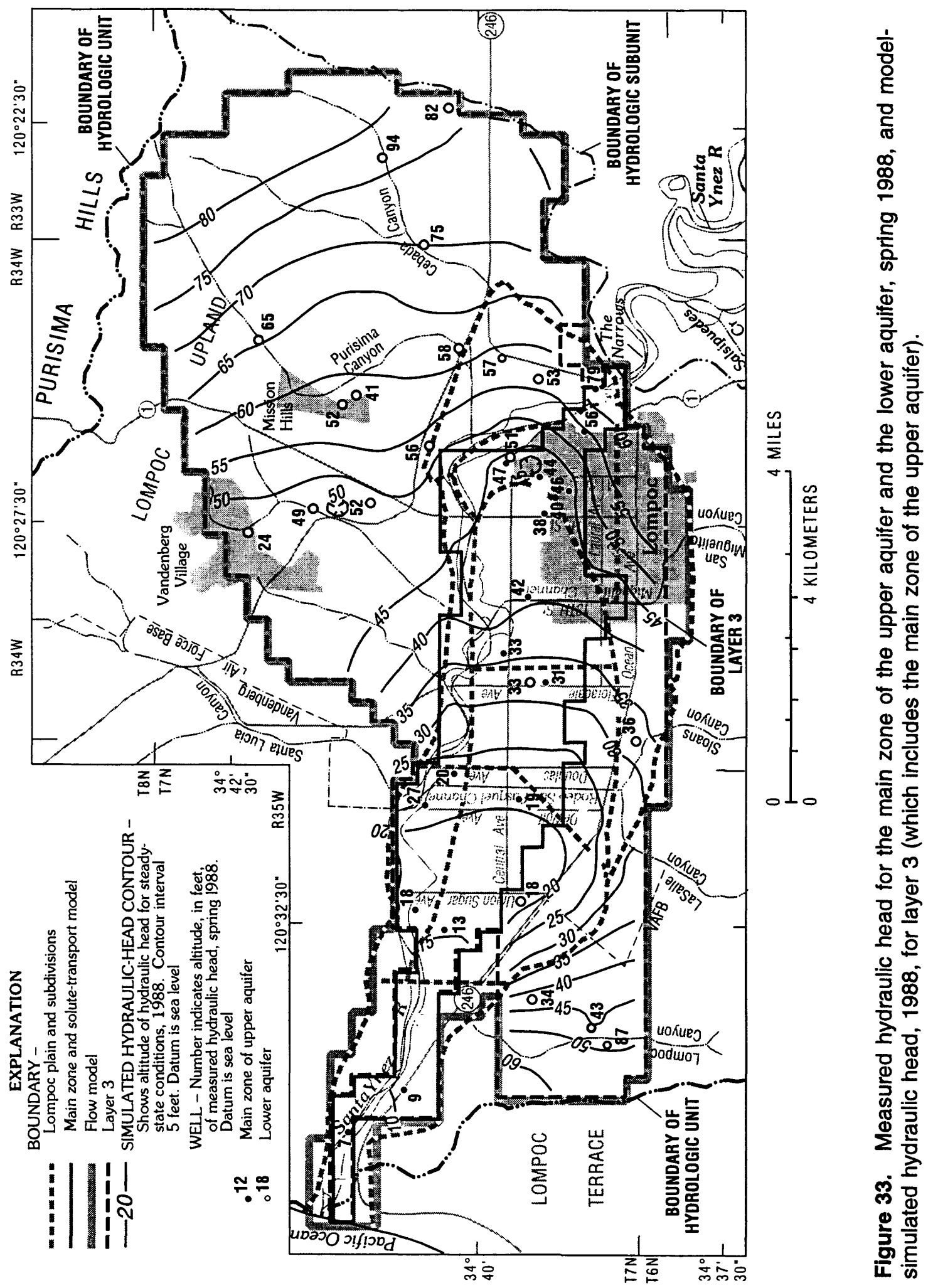



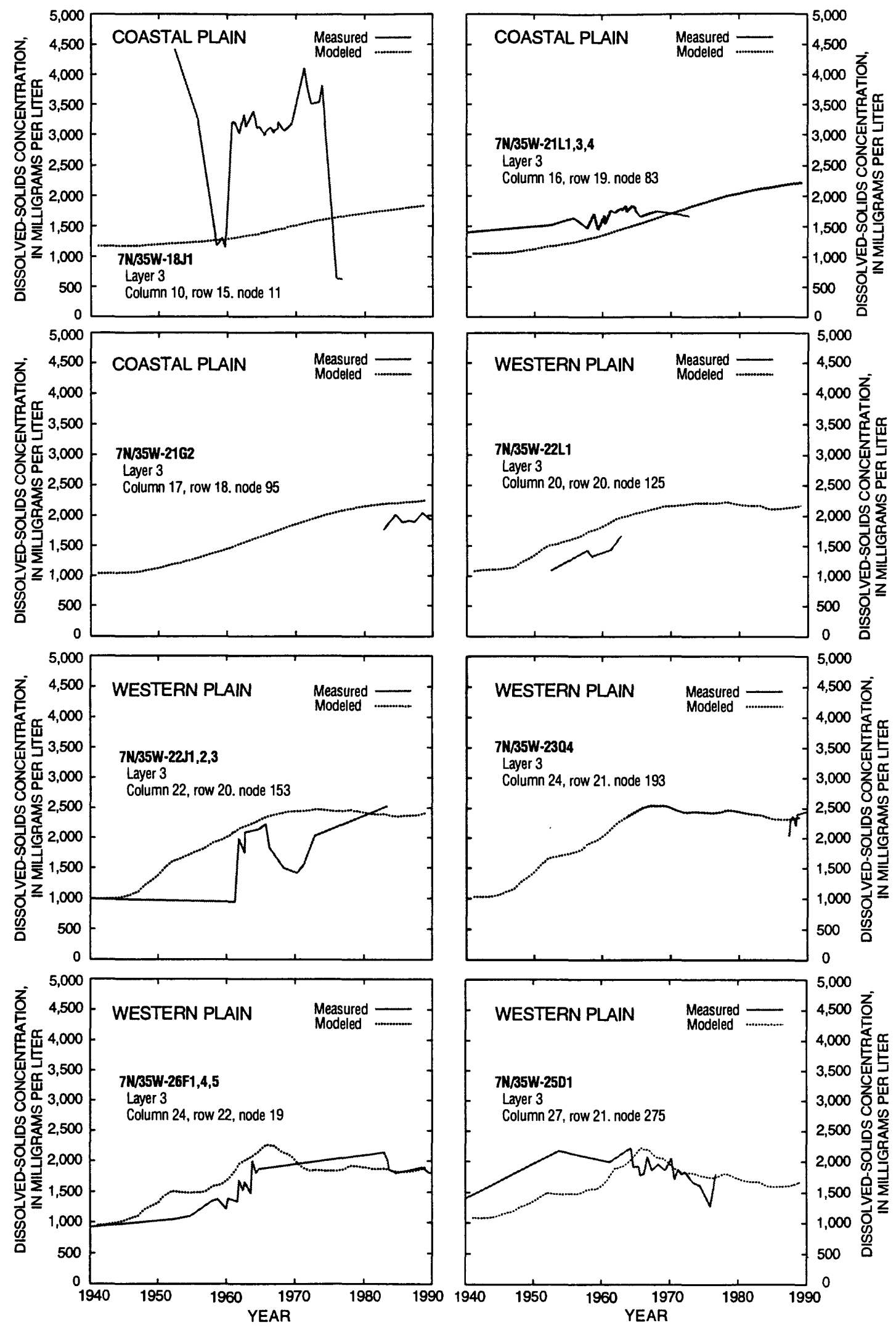

Figure 34. Measured and model-simulated dissolved-solids concentration at selected wells in the main zone of the upper aquifer in the Lompoc area, 1941-88. 

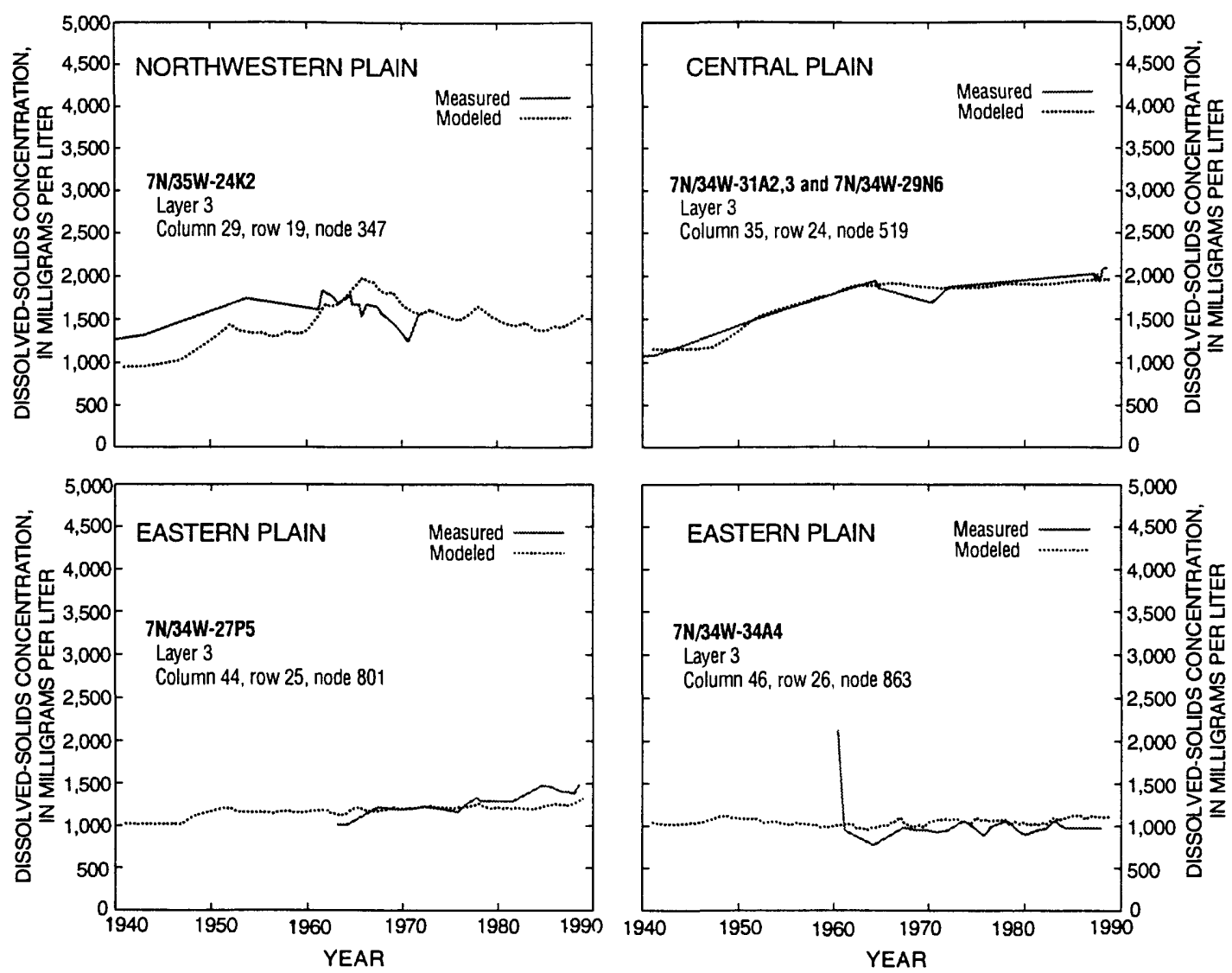

Figure 34.-Continued.

values. The similarity between measured and simulated dissolved-solids concentration during the transient-state period indicates that the model adequately approximates the source and sinks of dissolved-solids concentration to or from the main zone and the movement of high dissolved solids water through the main zone.

\section{Model Results}

A summary water budget of all simulated recharge and discharge components calculated by the flow model for the steady-state and transient-state simulations are presented in table 15 . During 1941-88 about 1,096,000 acre-ft of water was pumped from the aquifer system. Average pumpage for the transient simulation $(22,830$ acre- $\mathrm{ft} / \mathrm{yr})$ exceeded pumpage for the steady-state simulation $(6,240$ acre-ft/yr) by 16,590 acre-ft/yr. Of this increase in pumpage during the transient-state period, about 60 percent $(9,880$ acre- $\mathrm{ft} / \mathrm{yr})$ was contributed by increased recharge, 28 percent $(4,590 \mathrm{acre}-\mathrm{ft} / \mathrm{yr})$ by decreased natural discharge from the system (primarily discharge to the Santa Ynez River and transpiration), and 13 percent $(2,120 \mathrm{acre}-\mathrm{ft} / \mathrm{yr})$ was withdrawn from storage.

During the steady-state simulation, hydraulic heads were near land surface, causing a considerable quantity of potential recharge to be rejected. Simulated steady-state recharge along the Santa Ynez River equaled 2,030 acre-ft/yr (table 15). Lowered ground-water levels and steeper gradients during 1941-88 increased available storage and allowed a greater influx of flows in the Santa Ynez River to recharge the basin. Average Santa Ynez River recharge (7,760 acre-ft/yr) was about 5,730 acre-ft/yr 


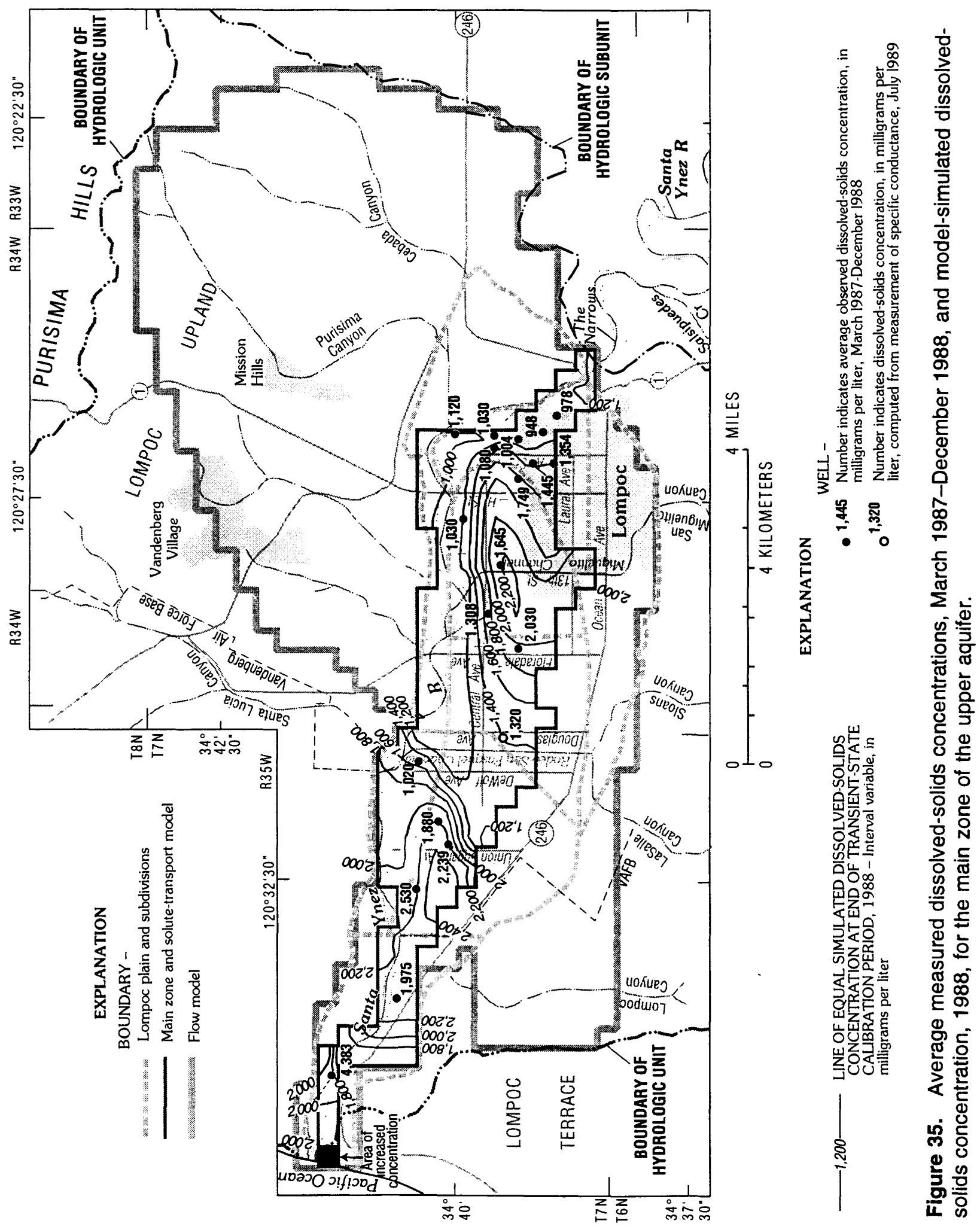


Table 15. Steady-state and transient water budgets in the Lompoc area (all values in acre-feet per year, negative sign indicates water removed from aquifer system)

\begin{tabular}{|c|c|c|c|c|}
\hline & \multirow[b]{2}{*}{ Steady state } & \multicolumn{3}{|c|}{ Transient state } \\
\hline & & 1941 & $\begin{array}{l}\text { Average } \\
1941-88\end{array}$ & 1988 \\
\hline \multicolumn{5}{|l|}{ Recharge: } \\
\hline \multicolumn{5}{|l|}{ Santa Ynez River loss- } \\
\hline Narrows to H Street & 2,031 & 1,248 & 4,151 & 1,017 \\
\hline H Street to LRWTP & 0 & 0 & 578 & 0 \\
\hline LRWTP to Douglas Avenue & 0 & 0 & 2,275 & 1,972 \\
\hline Douglas Avenue to Union Sugar Avenue & 0 & 0 & 752 & 0 \\
\hline \multicolumn{5}{|l|}{ Rainfall infiltration } \\
\hline Lompoc Plain & 4,633 & 13,015 & 4,536 & 3,520 \\
\hline Lompoc Upland & 2,016 & 2,016 & 2,016 & 2,016 \\
\hline Lompoc Terrace & 333 & 333 & 333 & 333 \\
\hline Southern streams & 1,368 & 6,057 & 1,368 & 546 \\
\hline Underflow at Narrows & 382 & 412 & 523 & 861 \\
\hline Seepage from consolidated rocks & 0 & -290 & 838 & 1,469 \\
\hline Irrigation return flow & 1,989 & 1,989 & 5,262 & 6,490 \\
\hline Total recharge & 12,752 & 24,780 & 22,632 & 18,224 \\
\hline \multicolumn{5}{|l|}{ Discharge: } \\
\hline \multicolumn{5}{|l|}{ Santa Ynez Channel gain } \\
\hline H Street to LRWTP & .706 & $-1,006$ & 0 & 0 \\
\hline LRWTP to Douglas Avenue & $-1,309$ & $-1,771$ & 0 & 0 \\
\hline Douglas Avenue to Union Sugar Avenue & -574 & -822 & 0 & 0 \\
\hline Union Sugar Avenue to Surf & -930 & $-1,472$ & -159 & -139 \\
\hline Pumpage & $-6,240$ & $-6,240$ & $-22,833$ & $-30,866$ \\
\hline Transpiration & $-2,816$ & $-3,084$ & $-1,686$ & -853 \\
\hline Underflow to ocean & -45 & -168 & -35 & -18 \\
\hline Agricultural drains & -120 & -197 & -35 & -10 \\
\hline Total discharge & $-12,740$ & $-14,760$ & $-24,748$ & $-31,886$ \\
\hline Difference between recharge and discharge & -12 & 10,020 & $-2,116$ & $-13,662$ \\
\hline Storage depletion ${ }^{1}$ & 0 & 10,009 & $-2,103$ & $-13,621$ \\
\hline
\end{tabular}

${ }^{\mathrm{T}}$ The difference between recharge and discharge should be equal to storage depletion. The observed differences are due to accumulation of small consistent errors in the model and to rounding of large numbers. 
higher than the steady-state recharge. During the steady-state simulation the Santa Ynez River only recharged the basin in the reach from the Narrows to H Street; whereas, during the transient-state simulation recharge occurred from the Narrows to Union Sugar Avenue (table 15). A large percentage of the recharge downstream of the LRWTP discharge point is seepage of sewage treatment discharge (table 6). The simulated average rate and distribution of Santa Ynez River recharge are similar to previous estimates (table 2).

The increase in pumpage induced water to migrate upward from the consolidated rocks in the western and coastal plain into the main zone of the upper aquifer. Because the head in the consolidated rocks was set equal to the head in the main zone during the steady-state simulation, there was no flow into or out of the consolidated rocks during the steady-state simulation. As shown in table 15 , the model simulated flow from the main zone to the underlying consolidated rocks during extremely wet periods, such as 1941, when the simulated head in the main zone of the upper aquifer was higher than the simulated steady-state head.

The lowered ground-water levels during 1941-88 also reduced natural discharge by decreasing plant transpiration (1,130 acre-ft/yr) and seepage from the shallow zone to the Santa Ynez River (3,360 acre-ft/yr) compared to the steady-state simulation. During the steady-state simulation discharge to the Santa Ynez River occurred from H Street to Surf. However, during the transient-state simulation only the reach from Union Sugar Avenue to Surf had a net average gain in flow (table 15).

Model results indicate, however, that increased recharge and decreased discharge during 1941-88 did not sufficiently balance the increase in pumpage during the transient-state period (796,460 acre-ft). Thus, storage in the aquifer system decreased by about 101,570 acre-ft $(2,120 \mathrm{acre}-\mathrm{ft} / \mathrm{yr})$ during this period. The reduction in storage has resulted in long-term water level-declines in the main zone beneath the plain and in the lower aquifer beneath the upland and terrace.

The percentage of annual pumpage derived from recharge, discharge, or storage changes with corresponding changes in the hydrologic conditions in the basin. For example, in 1988 the Lompoc area received less than average annual rainfall, and total pumpage was 30,870 acre- $\mathrm{ft}$. This pumpage exceeded the simulated steady-state pumpage by 24,630 acre-ft (table 15). Of this increase in pumpage, about 56 percent $(13,660$ acre- $\mathrm{ft})$ was contributed by release of water from storage, 22 percent $(5,470$ acre-ft) by increased recharge, and 22 percent $(5,480$ acre-ft) by decreased natural discharge.

The quantity of water recharging the main zone by (1) downward leakage from the overlying middle zone, (2) lateral leakage along the boundary with the main zone. (3) underflow at the narrows, (4) underflow from the ocean and (5) upward leakage from the lower aquifer and consolidated rocks averaged about 27,160 acre-ft/yr for the 48 -year simulation period. Downward leakage from the middle zone provided about 87 percent of the average annual recharge to the main zone $(23,670 \mathrm{acre}-\mathrm{ft} / \mathrm{yr})$, lateral leakage provided about 5 percent $(1,240 \mathrm{acre}-\mathrm{ft} / \mathrm{yr})$, underflow at the narrows provided about 2 percent ( 470 acre-ft/yr), underflow from the ocean provided about 0.3 percent $(80 \mathrm{acre}-\mathrm{ft} / \mathrm{yr})$, upward leakage from the lower aquifer provided about 3 percent $(860$ acre$\mathrm{ft} / \mathrm{yr}$ ), and upward leakage from consolidated rocks provided about 3 percent ( $840 \mathrm{acre}-\mathrm{ft} / \mathrm{yr}$ ). 
Downward leakage from the middle zone to the main zone in the northeastern and central plains and upward leakage from the consolidated rocks significantly increased from 1941-88 in response to increased pumpage, which increased from about 6,240 to 30,870 acre-ft/yr from 1941-88 (table 9). Both of these sources have relatively high dissolved-solids concentration compared with predevelopment concentrations in the main zone. (fig. 29). Downward leakage from the area of the middle zone with high dissolved-solids concentrations (the model cells with dissolved-solids concentrations in excess of $2,000 \mathrm{mg} / \mathrm{L}$ on figure $27 \mathrm{~B}$ ) increased from about 1,440 acre-ft/yr during the steady-state simulation to an average of 4,430 acre-ft/yr for 1941-88. Because the head in the consolidated rocks was set equal to the head in the main zone during the steady-state simulation, there was no flow into or out of the consolidated rocks during the steady-state simulation. However, upward leakage from the consolidated rocks averaged 840 acre-ft/yr for the transient simulation (1941-88). The increase in leakage from these two sources resulted in an increase in the dissolved-solids concentration of the main zone (fig. 34). The model results indicate that downward leakage from the middle zone was the main source of high dissolved-solids concentrations in the northeastern and central plains, whereas upward leakage from the consolidated rocks is the main source of the high dissolved-solids concentrations in the northwestern and western plains.

\section{Limitations of Models}

Although a ground-water model can be a useful tool for investigating aquifer response, it is a simplified approximation of the actual system based on average or estimated conditions, and the accuracy of its predictions are dependent on the accuracy of the input data. The flow model has been calibrated to observed long-term trends of hydraulic heads within specified areas of the Lompoc ground-water basin. The model is able to duplicate hydraulic heads fairly accurately in the main zone of the upper aquifer (figs. 31 and 33). Where there are sparse or no constraining data, however, the accuracy of the model is uncertain. For example sparse data are available on streamflow loss in the southern streams; therefore, recharge along the southern streams was estimated. Monitor wells in this area, and additional stream gages at Miguelito, Sloans, La Salle, and Lompoc Canyons, would help determine the actual distribution of recharge.

The ground-water divides constituting the eastern and southwestern edges of the modeled area (fig. 11) are represented as no-flow boundaries. For the model simulation period the no-flow boundaries are reasonable, because minimal ground-water development occurred near these boundaries. However, if future model simulations included significant pumpage near these boundaries, the model results should be used with caution. The model grid may need to be extended in these areas and alternative boundary conditions may need to be implemented to adequately simulate the effects of pumpage near these boundaries.

Water-level data for the Lompoc upland and terrace were not sufficient to describe the change in hydraulic head with depth. Because the Paso Robles Formation and Careaga Sand are stratified deposits, simulations were done to check the model's response to confined conditions by determining the sensitivity of hydraulic head in the lower aquifer to changes in the storage coefficient and vertical leakage between layers. Decreasing the storage coefficient amplified the historical trend of declining heads beneath the upland and terrace, due principally to municipal and military pumping, respectively. Simulated heads, using the lower storage coefficients, could be maintained at measured levels only by increasing the simulated constant recharge (from rainfall infiltration) above estimated values. For this 
reason, and because of the unsaturated zone that exists beneath the Orcutt Sand and within the Paso Robles Formation in the upland, layer 1 in the upland and terrace was simulated as unconfined. Multiple-well monitor sites in these areas would enable determination of the vertical-head change in the lower aquifer. Monitor wells located both within and outside canyon areas (for example, Purisima, Cebada, and Lompoc Canyons) would aid in the evaluation of the sources and movement of recharge in the upland and terrace.

Beneath the western plain, the lower aquifer is absent, and the hydraulic connection between the main zone and the underlying consolidated rocks is relatively unknown because there is only one monitor site 7N/35W-23E5-E8 (fig. 2) perforated in the consolidated rocks in this area. As a result of this paucity of data, heads used to simulate the consolidated rocks (table 4) were calculated during the steady-state simulation and then held constant during each stress period in the transient calibration. Also, the dissolved-solids concentration assigned to the consolidated rocks $(4,300 \mathrm{mg} / \mathrm{L})$ was estimated from the average dissolved-solids concentration of samples from monitor well $7 \mathrm{~N} / 35 \mathrm{~W}-23 \mathrm{E} 5$.

However, water-level and water-quality data collected from similar rocks in Santa Barbara County (Martin, 1984) indicate that the hydraulic head in consolidated rocks fluctuates in response to pumping from overlying alluvial deposits. Thus, during years of increased simulated pumpage and lowered hydraulic head in the main zone, the model probably overestimates the quantity of upward flow of water of relatively high dissolved-solids concentration from the underlying consolidated rocks.

The modeling of dissolved-solids concentration in the western and coastal plains is relatively sensitive to changes in either the hydraulic head or dissolved-solids concentration of the underlying consolidated rocks. The installation of multiple-well monitor sites that include wells perforated in the consolidated rocks beneath the main zone in the western plain, and perforated in the lower aquifer beneath the northeastern and northwestern plains, would enable more accurate simulation of the hydraulic connection between the main zone and underlying deposits.

The two-dimensional solute transport model used in this study does not model the vertical difference in solute-transport rates that are likely to be important in the main zone of the upper aquifer. Solute transport probably occurs at a much greater rate in the coarse-grained basal sediments of the main zone than in the fine-grained sediments present in the upper part of the main zone. Modeling the main zone as multiple layers would more accurately simulate solute transport in the main zone.

In the solute transport model, inflows and outflows to or from the main zone and the dissolvedsolids concentrations of the inflows are required as input data for the hydrologic units bounding the main zone. The model results are very sensitive to these bounding conditions. Unfortunately, there are scant water quality data available for the middle zone. The accuracy of the model could be improved by installing monitor wells throughout the middle zone.

The inflows and outflows to or from the main zone were simulated by the three-dimensional ground-water flow model. The flow between layers was calibrated by matching measured hydraulichead differences in the different layers and the measured dissolved-solids concentration in the main zone. Development of a multi-layer solute transport model for the Lompoc plain would allow more accurate calibration of the flow between layers by allowing both simulated hydraulic heads and dissolved-solids concentrations for each layer to be used in the calibration process. A calibrated multilayer solute transport model would be useful in evaluating the three-dimensional effects of groundwater development and artificial recharge on water levels and water quality. 


\section{SIMULATED EFFECTS OF PROPOSED MANAGEMENT ALTERNATIVES ON WATER LEVELS AND WATER QUALITY}

A reasonable match having been achieved between simulated and measured hydraulic heads and dissolved-solids concentrations for 1941-88, the calibrated model was used to estimate changes resulting from proposed management alternatives. For this study, three management alternatives suggested by cooperators were simulated:

(1) Average all model input parameters dependent on climatic conditions. These parameters include, for example, agricultural pumpage and all recharge components-except for sewageeffluent discharge to the Santa Ynez River [recharge for this component was set at a projected rate of $5.6 \mathrm{ft}^{3} / \mathrm{s}$ or $4,100 \mathrm{acre}-\mathrm{ft} / \mathrm{yr}$ (Gary Keefe, city of Lompoc, oral commun., 1989)]. This simulation represents the response of the ground-water system to average recharge and discharge conditions. By isolating the effects of average conditions, the relative response of the ground-water system to the conditions imposed in each of the remaining alternatives can be assessed. Consequently, this "no action or average conditions" management alternative serves as a standard for comparison of the two remaining alternatives.

(2) Move the LRWTP discharge point on the Santa Ynez River upstream from its present location to near Robinson Bridge (fig. 5). For this simulation, all the projected sewage-effluent discharge from the LRWTP ( $5.6 \mathrm{ft}^{3} / \mathrm{s}$ or 4,100 acre-ft/yr) was introduced as streamflow at the farthest upstream stream reach of the model (row 28, column 49).

(3) Increase streamflow in the Santa Ynez River by 3,000 acre-ft during the summer dry period to simulate the effect of artificial recharge in the river.

Each management alternative was modeled using hydraulic heads and dissolved-solids concentrations from the last stress period of the calibrated 1941-88 transient model as initial conditions. Each management alternative simulated 25 years (1989-2013). This time period was selected to ensure that results from the management alternative simulations would be useful for longterm planning of water resources. Each year simulated was divided into a wet and a dry period. Each wet stress period consisted of 139 days and each dry stress period consisted of 226 days (the average number of days for the 1941-88 wet and dry stress periods). The simulated effects of the proposed management alternatives on water levels and dissolved-solids concentration are illustrated in figures $36-37$.

For recharge, discharge, and dissolved-solids concentration-whose values were not adjusted in the management alternatives-the following procedures were followed:

(1) Long-term average (1941-88) recharge values for southern streams seepage and precipitation recharge were used for each stress period. These are the same values that were used in the steady-state simulation. The 1988 rate was used for the irrigation return flow value. The average streamflow for 1953-88 wet periods ( $94.6 \mathrm{ft}^{3} / \mathrm{s}$ or $\left.188 \mathrm{acre}-\mathrm{ft} / \mathrm{d}\right)$ and the average number of days (140 days) were used for each wet stress period. Similarly, the average streamflow $\left(3.5 \mathrm{ft}^{3} / \mathrm{s}\right.$ or 6.9 acre- $\left.\mathrm{ft} / \mathrm{d}\right)$ during the dry periods and the average number of days (225 days) were simulated for each dry period. Agricultural pumpage and municipal pumpage were assumed to remain constant at 1988 rates. 
EXPLANATION

LINE OF EQUAL SIMULATED

CHANGE IN HYDRAULIC HEAD -

Interval variable, in feet

4 - Increase or decrease $(-4)$ in hydraulic head

0 - No change
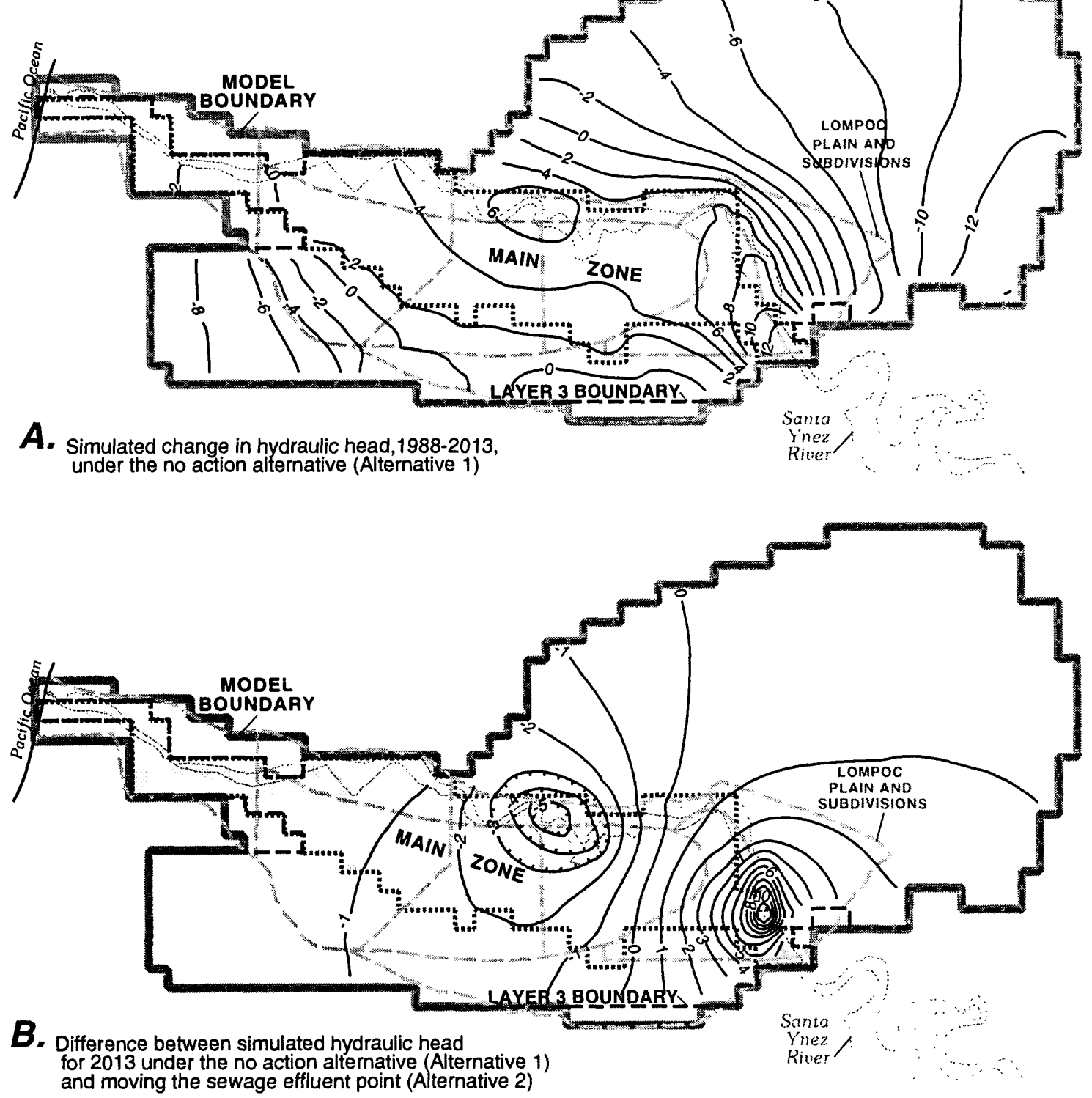

and moving the sewage effluent point (Alternative 2)

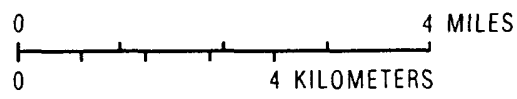

Figure 36. Simulated change in hydraulic head in layer 3 for management alternatives 1,2 , and 3 in the Lompoc area, 1988-2013. 

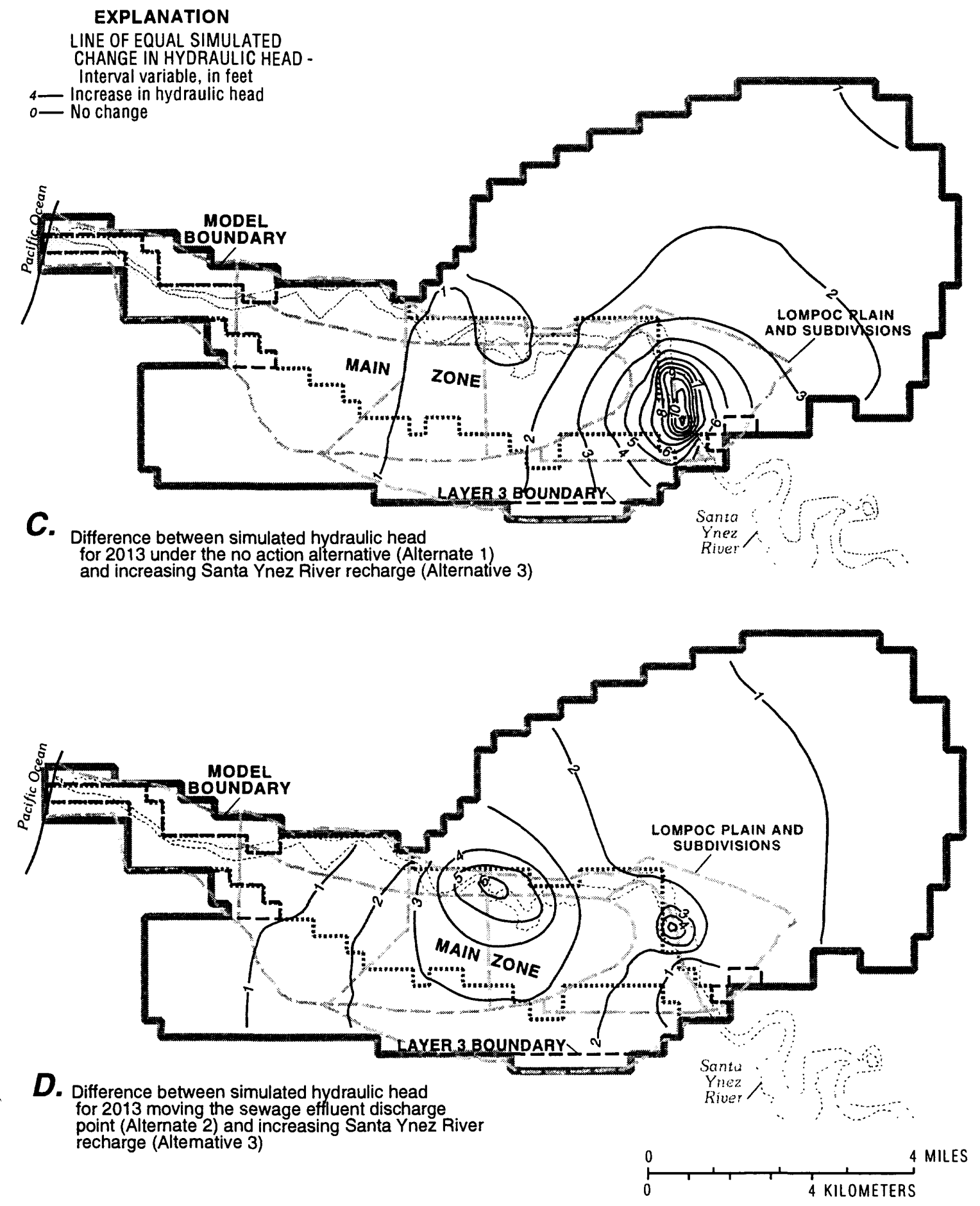

Figure 36.-Continued. 


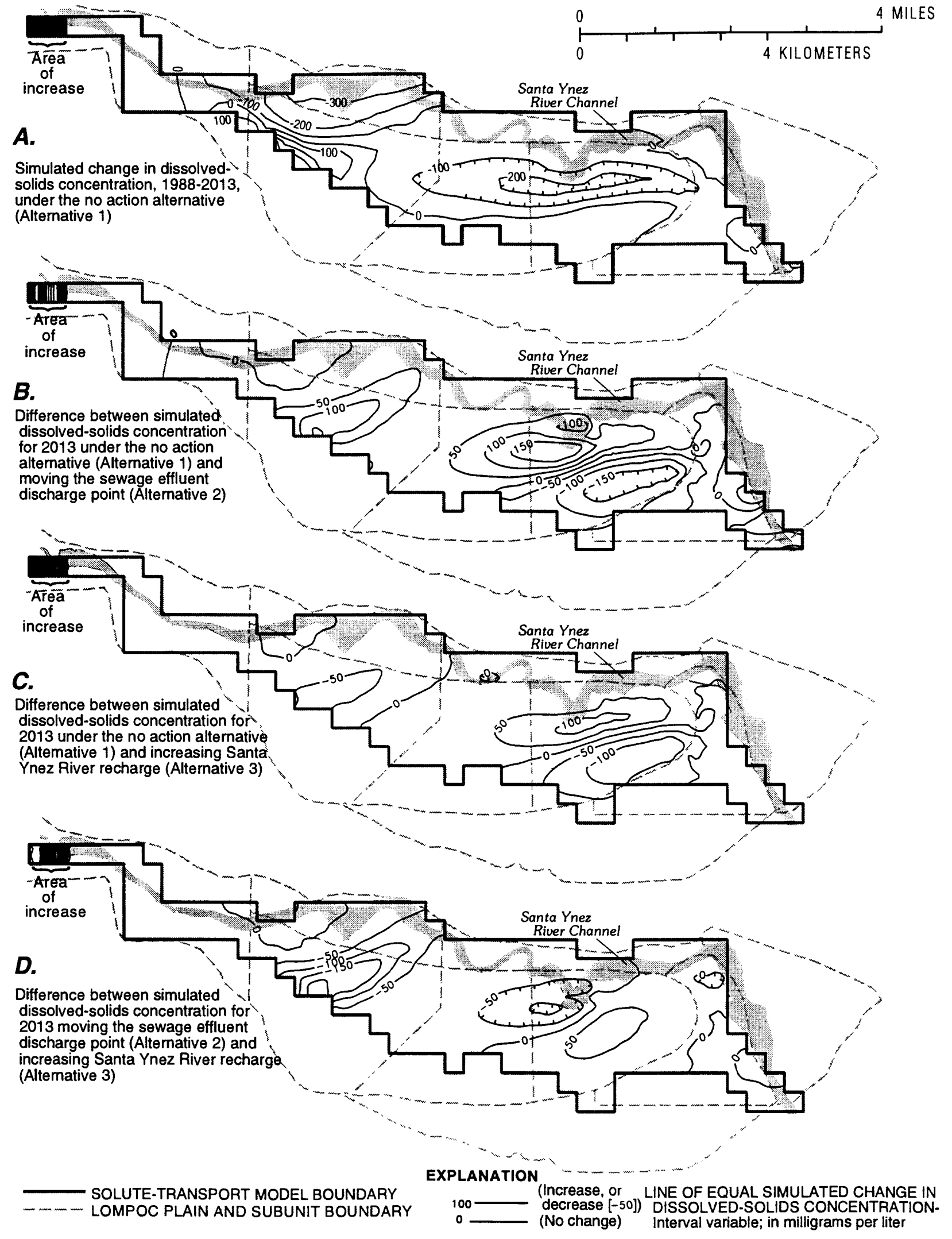

Figure 37. Simulated change in dissolved-solids concentration layer 3 in the Lompoc area for management alternatives 1,2 , and 3, 1988-2013. 
(2) Dissolved-solids concentrations used as input for the transient model for the simulated period 1941-88 were used to simulate inflow from the middle zone of the upper aquifer and from the lower aquifer, and to simulate lateral flow to the main zone (fig. 27).

(3) For alternative 1 recharge from the Santa Ynez River immediately downstream from the Narrows (variable model cells in figure 27B) was simulated using $800 \mathrm{mg} / \mathrm{L}$ for the wet periods and $1,300 \mathrm{mg} / \mathrm{L}$ for the dry periods.

(4) For alternative 2 the sewage effluent discharged from the LRWTP was assumed to have a dissolved-solids concentration of $1,000 \mathrm{mg} / \mathrm{L}$. Recharge from the combined flow of the natural streamflow and the sewage effluent was simulated using the flow weighted dissolved-solids concentration for the model cells immediately downstream from the narrows. The simulated values were $810 \mathrm{mg} / \mathrm{L}$ for the wet periods and $1,120 \mathrm{mg} / \mathrm{L}$ for the dry periods.

(5) For alternative 3 the increased streamflow in the Santa Ynez River was assumed to have a dissolved-solids concentration of $1,000 \mathrm{mg} / \mathrm{L}$. Recharge for the wet periods was unchanged and was simulate using $800 \mathrm{mg} / \mathrm{L}$ in the model cells immediately downstream from the narrows. Recharge from the combined flow of the natural and artificial streamflows during the simulated period was simulated using the flow weighted dissolved-solids concentration of 970 $\mathrm{mg} / \mathrm{L}$.

Because of the uncertainty of projecting future recharge and discharge conditions, and the limitations of the flow and transport models (see "Limitations of Models" section), absolute values of projected head and dissolved-solids concentration should be considered approximate; the actual value may vary significantly from the projected value. For example, simulated dissolved-solids concentrations near the coast vary from observed concentrations because density differences between freshwater and seawater cannot be accounted for in the solute-transport model. Therefore, projected dissolved-solids concentrations for the extreme western end of the coastal plain were not included as part of the management alternative simulations. However, for the remaining parts of the basin, relative comparisons of projected heads and concentrations from each management alternative can be made with a reasonable degree of certainty.

\section{Alternative 1: No Action}

On the basis of average recharge and discharge conditions, total discharge from the ground-water system exceeds total recharge to the system. However, the average rate of aquifer storage depletion (740 acre-ft/yr) for alternative 1 is significantly less than the average rate of storage depletion $(2,100$ acre-ft/yr) simulated during the transient-state period, 1941-88 (table 15). Recall that the average streamflow input along the Santa Ynez River was $94.6 \mathrm{ft}^{3} / \mathrm{s}$ for the wet stress periods and $3.5 \mathrm{ft}^{3} / \mathrm{s}$ for the dry stress periods. These average values, especially for the wet stress periods, are relatively high compared to most years of record because of a few extremely wet years (fig. 30). Therefore, in the management alternative simulations there is more streamflow available for recharge than there was for most years of the transient simulation. As a result, hydraulic head is projected to rise in all areas of the Lompoc plain (fig. 36). Heads are projected to rise as much as $12 \mathrm{ft}$ in the eastern plain to less than 2 $\mathrm{ft}$ in the coastal plain. Heads are projected to continue to decline in the uplands and the terrace. The maximum head decline is more than $12 \mathrm{ft}$ in the southeastern part of the uplands. The projected head declines in the uplands and terrace reflect the measured long-term trend of increased drawdown in these areas. 
Projected dissolved-solids concentrations decreased by as much as $200 \mathrm{mg} / \mathrm{L}$ in parts of the northeastern and central plains and by as much as $300 \mathrm{mg} / \mathrm{L}$ in the northwestern plain by the end of the simulation period (fig. 37). The decrease in dissolved-solids concentration is the result of increased recharge along the Santa Ynez River compared to 1988 values. In 1988 the recharge rate along the Santa Ynez River was about 2,990 acre-ft/yr (table 15), whereas the average recharge rate during the management alternative was 15,260 acre- $\mathrm{ft} / \mathrm{yr}$ (table 16). The simulated net recharge is less than 50 percent of the average annual streamflow simulated during this management alternative $(31,980$ acre$\mathrm{ft} / \mathrm{yr}$ ) (table 16). All of the streamflow simulated during the dry stress periods $(4,090 \mathrm{acre}-\mathrm{ft} / \mathrm{yr})$ recharged the aquifer system; however, only 41 percent $(11,550$ acre-ft/yr) of the streamflow simulated during the wet stress periods $(27,890$ acre-ft/yr) recharged the aquifer system (table 15). These results indicate that the long-term average wet-period streamflow and sewage effluent discharge exceeded the infiltration capacity of the Santa Ynez River streambed as simulated in the model.

The decrease in dissolved-solids concentration in the western plain is in part due to the rise in head in the western plain. Upward flow of poor-quality water from the underlying consolidated rocks is controlled by the difference in hydraulic head between the main zone and the consolidated rocks. Because the hydraulic heads used for the consolidated rocks are held constant at steady-state head values (table 4), any increase of head in the main zone will decrease the upward flow of poor-quality water from the consolidated rocks.

Projected dissolved-solids concentrations increased by more than $100 \mathrm{mg} / \mathrm{L}$ in the southern margins of the northeastern and western plains. The increase in concentrations is probably the result of the recharge water moving high dissolved-solids concentration water downgradient from the Santa Ynez River, the source of the recharge water.

\section{Alternative 2: Move Sewage-Effluent Discharge Point}

Under conditions used for the second management alternative-that is, moving the LRWTP discharge point-projected hydraulic-heads increase compared to the no action conditions (alternative 1) throughout the main zone and the lower aquifer east of LRWTP discharge point (fig. 36B). Increased recharge from sewage-effluent discharge along the eastern boundary of the plain is sufficient to cause a maximum rise in head of $10 \mathrm{ft}$ in the southern part of the eastern plain compared to alternative 1 . Hydraulic head is projected to decline west of the LRWTP discharge point, and the decline is largest in the western part of the northern plain (as much as $5 \mathrm{ft}$ ). This part of the plain (Douglas Avenue to Union Sugar Avenue) received most of the simulated recharge of sewage-effluent seepage from the Santa Ynez River during the transient calibration and management alternative 1 (tables 15 and 16) and is therefore most affected by the reduction of this recharge source to zero.

Dissolved-solids concentration in the main zone is projected to decrease more than $150 \mathrm{mg} / \mathrm{L}$ beneath the southern part of the northeastern plain as a result of the second management alternative compared to the no action (alternative 1) by 2013 (fig. 37B). Projected decreases in dissolved-solids concentrations are due to increased hydraulic head in the main zone and increased recharge of water of relatively low dissolved-solids concentration from seepage along the Santa Ynez River. This recharge dilutes the inflow of water of relatively high dissolved-solids concentration from the overlying middle zone in the northeastern plain. 
Table 16. Simulated average streamflow and recharge along the Santa Ynez River for management alternatives 1, 2, and 3 in the Lompoc area, 1988-2013.

(all values are in acre-feet)

\begin{tabular}{|c|c|c|c|c|c|c|c|}
\hline \multirow{2}{*}{ Stream reach } & & \multicolumn{2}{|c|}{ Alternative 1} & \multicolumn{2}{|c|}{ Alternative 2} & \multicolumn{2}{|c|}{ Alternative 3} \\
\hline & & Streamflow & Recharge & Streamflow & Recharge & Streamflow & Recharge \\
\hline \multicolumn{8}{|c|}{ Narrows to H Street } \\
\hline & wet & 26,320 & 6,250 & 27,890 & 4,930 & 26,320 & 4,380 \\
\hline & dry & 1,560 & 1,560 & 4,100 & 4,100 & 4,560 & 4,560 \\
\hline & total & 27,880 & 7,810 & 31,990 & 9,030 & 30,880 & 8,940 \\
\hline
\end{tabular}

H Street to LRWTP

\begin{tabular}{lrrrrrr} 
wet & 0 & 1,540 & 0 & 1,610 & 0 & 1,280 \\
dry & 0 & 0 & 0 & 0 & 0 & 0 \\
\cline { 2 - 7 } total & 0 & 1,540 & 0 & 1,610 & 0 & 1,280
\end{tabular}

LRWTP to Douglas

Avenue

\begin{tabular}{lrrrrrr} 
wet & 1,570 & 1,910 & 0 & 2,820 & 1,570 & 1,690 \\
dry & 2,530 & 2,530 & 0 & 0 & 2,530 & 2,530 \\
\cline { 2 - 7 } total & 4,100 & 4,440 & 0 & 2,820 & 4,100 & 4,220
\end{tabular}

Douglas Avenue to

Union Sugar Avenue wet

dry

\begin{tabular}{rrrrrr}
0 & 1,500 & 0 & 1,650 & 0 & 1,430 \\
0 & 0 & 0 & 0 & 0 & 0 \\
\hline 0 & 1,500 & 0 & 1,650 & 0 & 1,430
\end{tabular}

Union Sugar Avenue to Surf

\begin{tabular}{lrrrrrr} 
wet & 0 & 350 & 0 & 380 & 0 & 350 \\
dry & 0 & -380 & 0 & -380 & 0 & -390 \\
\cline { 2 - 7 } total & 0 & -30 & 0 & 0 & 0 & -40 \\
\cline { 2 - 7 }$\ldots \ldots$ & 31,980 & 15,260 & 31,990 & 15,110 & 34,980 & 15,830 \\
\hline
\end{tabular}




\begin{abstract}
Although projected dissolved-solids concentrations decrease in the southern part of the northeastern plain, concentrations in the western part of the northeastern plain and the eastern part of the central plain are projected to increase by as much as $150 \mathrm{mg} / \mathrm{L}$ under the second management alternative compared to the no action alternative (fig. 37B). Dissolved-solids concentrations continued to increase in this management alternative because there is less recharge in the lower reaches of the Santa Ynez River. Simulated average recharge along the Santa Ynez River from LRWTP to Union Sugar Avenue was about 1,470 acre-ft/yr less in management alternative 2 compared to alternative 1 (table 16). Dissolved-solids concentrations in the western plain are projected to increase by as much as $100 \mathrm{mg} / \mathrm{L}$ compared to the no action alternative. Upward flow of poor quality water (dissolved-solids concentration of $4,300 \mathrm{mg} / \mathrm{L}$ ) from the underlying fractured consolidated rocks increased in the western plain compared to the no action alternative. The reduced recharge downstream of the LRWTP (table 16) resulted in lower hydraulic head in the main zone in the western plain which in turn increased the simulated gradient between the main zone and the underlying consolidated rocks. Upward flow from the underlying consolidated rocks is primarily controlled by the difference in hydraulic head between this unit and the overlying main zone.
\end{abstract}

\title{
Alternative 3: Increase Santa Ynez River Recharge
}

For the third management alternative, hydraulic head is projected to increase throughout the main zone and the lower aquifer in response to increasing recharge along the Santa Ynez River compared to the no action alternative (alternative 1). The largest increase in head (as much as $10 \mathrm{ft}$ ) is in the southern part of eastern plain beneath the Santa Ynez River (fig. 36C). The simulated increase in hydraulic head is the result of the greater net average Santa Ynez River recharge in alternative 3 (about 15,830 acre-ft/yr) compared to the net average recharge simulated in alternative $1(15,260$ acre$\mathrm{ft} / \mathrm{yr}$ ). Simulated average Santa Ynez River recharge in the eastern plain (Narrows to H Street) was about 1,130 acre-ft/yr higher in management alternative 3 compared to alternative 1 (table 16).

Implementing management alternative 3 also results in decreased dissolved-solids concentration (more than $100 \mathrm{mg} / \mathrm{L}$ in places) in the main zone beneath the eastern and northeastern plains (fig. 37C) compared to the no action alternative (alternative 1). As in alternative 2, this decrease is due to increased recharge of better quality (lower dissolved-solids concentration) water from the Santa Ynez River, which dilutes the inflow of poorer quality water from the overlying middle zone in the northeastern plain.

Dissolved-solids concentrations also are projected to decrease more than $50 \mathrm{mg} / \mathrm{L}$ beneath the western plain as a result of the implementation of management alternative 3 compared to the no action alternative. Because head in the main zone is projected to rise slightly as a result of this management alternative, the influx of water with high dissolved-solids concentration (about 4,300 $\mathrm{mg} / \mathrm{L}$ ) from the underlying consolidated rocks is reduced. As a result, the dissolved-solids concentration is projected to decrease in this area during 1989-2013 compared to average recharge conditions simulated in alternative 1.

Dissolved-solid concentration are projected to increase (more than $100 \mathrm{mg} / \mathrm{L}$ in places) in the northern part of the northeastern and central plains. This is due in part to the average $260 \mathrm{acre}-\mathrm{ft} / \mathrm{yr}$ reduction in recharge in the eastern part of the northern plain (H Street to LRWTP) in alternative 3 compared to alternative 1 (table 16). However, most of the increase is probably the result of the increased recharge in the eastern plain moving the water with high dissolved-solid concentration to the northwest. 
Compared to management alternative 2, heads are projected to be higher throughout the main zone and the lower aquifer in the uplands and terrace by 2013 in management alternative 3 (fig. 36D). The projected higher heads are the result of a greater net recharge along the Santa Ynez River in management alternative 3 (table 16). Dissolved-solids concentration are projected to be slightly higher (more than $50 \mathrm{mg} / \mathrm{L}$ in places) in the northeastern and central plains compared to management alternative 2 . However, dissolved-solids concentration are projected to be more than $150 \mathrm{mg} / \mathrm{L}$ lower in parts of the northwestern and western plains compared to management alternative 2 . The dissolvedsolids concentrations are higher in the northeastern and central plains, because the average recharge in the Santa Ynez River from the Narrows to the LRWTP was 420 acre-ft/yr less in management alternative 3 compared to management alternative 2 (table 16). Therefore, there was less low dissolved-solids concentration water to dilute the high dissolved-solids concentration leakage from the middle zone. The dissolved-solids concentration is lower in management alternative 3 in the northwestern and western plains because there is a an average of 1,180 acre- $\mathrm{ft} / \mathrm{yr}$ more recharge along the Santa Ynez River from the LRWTP to Union Sugar Avenue downgradient of the LRWTP compared to management alternative 2 (table 16).

\section{SUMMARY AND CONCLUSIONS}

The unconsolidated deposits in the Lompoc area have been divided into upper and lower aquifers. The river-channel deposits and younger alluvium form the upper aquifer in the Lompoc plain. The upper aquifer has been subdivided into three water-bearing zones: (1) the shallow zone, (2) the middle zone, and (3) the main zone. Deposits in the shallow zone are of low permeability and confine or partly confine the underlying deposits in the northeastern, central, and western Lompoc plains. The middle zone is separated from the overlying shallow zone and underlying main zone by lenses of silt and clay. Deposits in the main zone are relatively permeable. The main zone has been the principal source of water in the Lompoc plain. The Paso Robles Formation and Careaga Sand generally form the saturated part of the lower aquifer. The lower aquifer has been the primary source of water in the Lompoc upland and Lompoc terrace. Beneath the Lompoc plain the lower aquifer has not been used extensively as a source of water.

A three-dimensional finite-difference model, MODFLOW, was applied to simulate and evaluate ground-water flow in the Lompoc area. The aquifer system was simulated as four horizontal layers. For the Lompoc plain, the upper three layers represent the shallow, middle, and main zones of the upper aquifer, and the bottom layer represents the lower aquifer. For the Lompoc upland and Lompoc terrace, all four layers represent the lower aquifer.

A two-dimensional finite-element model, SUTRA, was used to simulate solute transport in the main zone of the upper aquifer. As written, SUTRA does not allow variable time step and allows only one fluid source or sink per node. In order to simulate the main zone, SUTRA was modified for this study to allow variable time steps and multiple sources or sinks.

The models were calibrated to transient conditions for 1941-88. A steady-state simulation was made to provide initial conditions for the transient-state simulation by using long-term average (1941-88) recharge rates. For both steady-state and transient conditions, model-simulated hydraulic heads generally were within $5 \mathrm{ft}$ of measured hydraulic heads in the main zone. Model-simulated dissolved-solids concentrations generally differed less than $200 \mathrm{mg} / \mathrm{L}$ from observed values. 
During 1941-88 about 1,096,000 acre-ft of water was pumped from the aquifer system. Average pumpage for the transient simulation $(22,830$ acre- $\mathrm{ft} / \mathrm{yr})$ exceeded pumpage for the steady-state simulation $(6,240 \mathrm{acre}-\mathrm{ft} / \mathrm{yr})$ by $16,590 \mathrm{acre}-\mathrm{ft} / \mathrm{yr}$. Of this increase in pumpage during the transientstate period, about 60 percent $(9,980$ acre-ft/yr) was contributed by increased recharge, 28 percent (4,590 acre-ft/yr) by decreased natural discharge from the system (primarily discharge to the Santa Ynez River and transpiration), and 13 percent (2,120 acre-ft/yr) was withdrawn from storage.

During the steady-state simulation, hydraulic heads were near land surface, causing a considerable quantity of potential recharge to be rejected. Lowered ground-water levels and steeper gradients during 1941-88 increased available storage and the model simulated about 5,730 acre-ft/yr more recharge from the Santa Ynez River compared to the steady-state simulation. The increase in pumpage also induced water to migrate upward from the consolidated rocks in the western and coastal plain into the main zone of the upper aquifer. Because the head in the consolidated rocks was set equal to the head in the main zone during the steady-state simulation, there was no flow into or out of the consolidated rocks during the steady-state simulation. During the transient period, the model simulated about 840 acre-ft/yr of flow from the consolidated rocks to the main zone. The lowered ground-water levels during 1941-88 also reduced natural discharge from the ground-water system. The model simulated that plant transpiration and seepage from the shallow zone to the Santa Ynez. River decreased by 1,130 and 3,360 acre-ft/yr, respectively, compared to the steady-state simulation.

Model results indicate that increase recharge and decrease discharge during 1941-88 did not sufficiently balance the increase in pumpage during the transient-state period. Thus, storage in the aquifer system decreased by about 101,570 acre-ft during this period. The reduction in storage has resulted in long-term water-level declines in the aquifer system, which have caused dissolved-solids concentrations to increase throughout most of the main zone of the upper aquifer.

Simulated downward leakage from the middle zone to the main zone in the northeastern and central plains and upward leakage from the consolidated rocks to the main zone significantly increased from 1941-88 in response to increased pumpage, which increased from about 6,240 to 30,870 acre$\mathrm{ft} / \mathrm{yr}$ from 1941-88. Model simulated downward leakage from the middle zone in the northeastern and central plains with high dissolved-solids concentration (in excess of $2,000 \mathrm{mg} / \mathrm{L}$ ) was $1,440 \mathrm{acre}-\mathrm{ft} / \mathrm{yr}$ and there was no flow into or out of the consolidated rocks during the steady-state simulation; whereas, downward leakage from the middle zone in the northeastern and central plains with high dissolved-solids concentration averaged 4,430 acre- $\mathrm{ft} / \mathrm{yr}$ and upward leakage from the consolidated rocks averaged 840 acre- $\mathrm{ft} / \mathrm{yr}$ for 1941-88. Because the dissolved-solids concentration of the middle zone in the northeastern and central plains and the consolidated rocks is higher than the simulated steady-state dissolved-solids concentration of the main zone, the increase in leakage from these two sources resulted in increased dissolved-solids concentration in the main zone during the transient period. The model results indicate that downward leakage from the middle zone was the main source of increased dissolved-solids concentrations in the northeastern and central plains; whereas, upward leakage from the consolidated rocks was the main source of the increased dissolved-solids concentrations in the northwestern and western plains.

The models were used to estimate changes in hydraulic head and dissolved-solids concentration for a 25-year period (1989-2013) resulting from three proposed management alternatives: (1) no action, (2) move the LRWTP discharge point on the Santa Ynez River upstream from its present location to near Robinson Bridge, (3) increase the quantity of streamflow to the Santa Ynez River at the Narrows by 3,000 acre-ft during the summer dry periods. Management alternatives 2 and 3 were compared with the no action alternative (alternative 1). Moving the LRWTP discharge point upstream (alternative 2) will result in an increase in hydraulic head throughout most of the main zone and lower aquifer east of the current (1989) LRWTP discharge point; however, the move will result in a decrease in hydraulic head in the main zone and lower aquifer west of the LRWTP discharge point in comparison with the no action alternative. The movement of the LRWTP discharge point will decrease the dissolved-solids concentration of the main zone by as much as $150 \mathrm{mg} / \mathrm{L}$ in the southern part of the northeastern plain compared to the no action alternative by 2,013 , but it will increase the dissolved-solids concentration 
in the main zone by as much as $150 \mathrm{mg} / \mathrm{L}$ in parts of the northwestern, central, and western plains. Increasing the streamflow along the Santa Ynez River during the summer periods (alternative 3) will result in an increase in hydraulic head throughout the main zone and lower aquifer. The increase in recharge will lower the dissolved-solids concentration by as much as $100 \mathrm{mg} / \mathrm{L}$ in the eastern and northeastern plains by dilution of the leakage from the middle zone in this part of the plain. The increase in hydraulic head in the northwestern and western plains will reduce the upward leakage of poor-quality flow from the underlying consolidated rocks, lowering dissolved-solids concentrations by as much as $50 \mathrm{mg} / \mathrm{L}$ in this part of the plain in comparison with the no action alternative.

\section{REFERENCES CITED}

Ahlroth, J.A., Lawrence, C.H., MacDonald, P.S., and Wasserman, C.B., 1977, Adequacy of the groundwater resources in the Lompoc Area: Santa Barbara County Water Agency, 38 p.

Barnes, Harry H., Jr. 1977, Roughness characteristics of natural channels: U. S. Geological Survey Water-Supply Paper 1849, $213 \mathrm{p}$.

Berenbrock, Charles, 1988, Ground-water quality in the Lompoc plain, Santa Barbara County, California: U.S. Geological Survey Water-Resources Investigations Report, 87-4101, 54 p.

Blaney, H.F., Nixon, P.R., Lawless, G.P., Wiedman, E.J., 1963, Utilization of the waters of the Santa Ynez River basin for agriculture in southern Santa Barbara County, California: U.S. Department of Agriculture, Agriculture Research Service, $53 \mathrm{p}$.

Bouwer, Herman, 1980, Deep percolation and groundwater management in Proceedings of the deep percolation symposium: Arizona Department of Water Resources Report No. 1, 118 p.

Bright, D.J., Stamos, C.L., Martin, P., and Nash, D.B., 1992, Ground-water hydrology and quality in the Lompoc area, Santa Barbara County, California, 1987-88: U.S. Geological Survey Water-Resources Investigations Report 91-4172, 77 p.

California Department of Water Resources, 1964, Names and areal code numbers of hydrologic areas in the southern district, $67 \mathrm{p}$.

1987, Southern central coast land use survey, 1985, $25 \mathrm{p}$.

Dibblee, T.W., Jr., 1950, Geology of southwestern Santa Barbara County, California, Point Arguello, Lompoc, Point Conception, Los Olivos, and Gaviota quadrangles: California Division of Mines Bulletin 150, $95 \mathrm{p}$.

Evenson, R.E., 1964, Suitability of irrigation water and changes in ground-water quality in the Lompoc subarea of the Santa Ynez River basin, Santa Barbara County, California: U.S. Geological Survey Open-File Report, $62 \mathrm{p}$.

1966, Hydrologic inventory of the Lompoc subarea, Santa Ynez River basin, Santa Barbara County, California, 1957-62, with a section on perennial supply by R.E. Evenson and G.F. Worts, Jr.: U.S. Geological Survey Open-File Report, 27 p.

Evenson, R.E., and Miller, G.A., 1963, Geology and ground-water features of Point Arguello Navel Missile Facility, Santa Barbara County, California: U.S. Geological Survey Water-Supply Paper 1619-F, 35 p.

Freeze, R.A., and Cherry, J.A., 1979, Groundwater: Prentice-Hall, Inc., Englewood Cliffs, New Jersey, 604 p.

Gelhar, L.W., Welty, Claire, and Rehfeldt, K.R., 1992, A critical review of data on field-scale dispersion in aquifers: Water Resources Research, v. 28, no. 7, p. 1955-1974.

Hillel, Daniel, 1971, Soil and water: physical principles and processes: New York, Academic Press, 288 p.

Lohman, S.W., 1972, Ground-water hydraulics: U.S. Geological Survey Professional Paper 708, 70 p.

Martin, Peter, 1984, Ground-water monitoring at Santa Barbara, California: Phase 2-Effects of pumping on water levels and water quality in the Santa Barbara ground-water basin: U.S. Geological Survey WaterSupply Paper 2197, $31 \mathrm{p}$.

McDonald, M.G., and Harbaugh, A.W., 1988, A modular three-dimensional finite-difference ground-water flow model: Techniques of Water-Resources Investigations of the U.S. Geological Survey, Chapter A1, Book $6,576 \mathrm{p}$.

Mercer, J.W., Thomas, S.D., and Ross, B., 1982, Parameters and variables appearing in repository siting models, U.S. Nuclear Regulatory Commission, NUREG/CR-3066, 220 p.

Miller, G.A., 1976, Ground-water resources in the Lompoc area, Santa Barbara County, California: U.S. Geological Survey Open-File Report 76-183, 78 p. 
National Oceanic and Atmospheric Administration, 1976-88, Climatological data--California: annual summaries, v. 80-92.

Neuman, S.P., and Witherspoon, P.A., 1972, Field determination of the hydraulic properties of leaky multiple aquifer systems: Water Resources Research, v. 8, no. 5, p. 1284-1298.

Prudic, D.E., 1989, Documentation of a computer program to simulate stream-aquifer relations using a modular, finite-difference, ground-water low model: U.S. Geological Survey Open-File Report 88-729, 113 p.

Sampson, Robert J., 1978, Surface II graphics system: Kansas Geological Survey, 240 p.

Upson, J.E., and Thomasson, H.G., Jr., 1951, Geology and water resources of the Santa Ynez River basin, Santa Barbara County, California: U.S. Geological Survey Water-Supply Paper 1107, 194 p.

U.S. Bureau of Reclamation, 1964-75, Progress reports on investigations, measurements, and studies during water years 1962-73, Santa Ynez River, Cachuma Project, 17 p.

U.S. Department of Agriculture, Weather Bureau, 1910-30, Climatic summary of the United States: section 17-Central California, $64 \mathrm{p}$.

U.S. Department of Commerce, Weather Bureau, 1954-76; Climatological data-California: Annual summaries [for 1953-75], v. 57-79.

Voss, C.I., 1984, SUTRA-A finite-element simulation model for saturated-unsaturated, fluid-density-dependant ground-water flow with energy transport or chemically-reactive single-species solute transport: U.S. Geological Survey Water-Resources Investigations Report 84-4369, 409 p.

Wilson, H.D., Jr., 1959, Ground-water appraisal of Santa Ynez River basin, Santa Barbara County, California, 1945-52: U.S. Geological Survey Water-Supply Paper 1467, 119 p.

Yates, E.B., 1988, Simulated effects of ground-water management alternatives for the Salinas Valley, California: U.S. Geological Survey Water-Resources Investigation Report 87-4066, 79 p. 
SUPPLEMENTAL DATA

- PAGE 107 FOLLOWS- 
SUPPLEMENTAL DATA: Modifications to SUTRA to allow variable time steps and to allow multiple sources or sinks per node

\section{VARIABLE TIME STEPS}

In the original model code (SUTRA version 0690-2D), the duration of the initial model time step (DELT in input data set 6) remains constant or may be increased or decreased by some fixed factor (DTMULT in input dataset 6) up to a maximum value (DTMAX in input dataset 6). Because the duration of the wet and dry periods varied from year to year, the code was modified to allow variable time steps. In order to invoke the variable time step option, ITMAX, the maximum allowed number of time steps in the simulation (input data set 6) is entered as a negative number (a positive value of ITMAX causes the model time step to be determined as it was in the original code). If a negative value is specified for ITMAX, the duration (in seconds for each model time step and (one time step per record) is specified in a new input data set 23.

\section{Input Data Set 23}

VARIABLE

DELT(1)

$\operatorname{DELT}(2)$

\section{FORMAT}

G10.0

G10.0

G10.0

G10.0

DELT(-ITMAX-1)

\section{MULTIPLE SOURCES OR SINKS}

A model node may potentially receive flux from four sources or sinks: lateral underflow, vertical leakage from the overlying middle zone, vertical leakage from the underlying lower aquifer or shale, and from pumpage. The solute concentration of the sources may differ. The original model code permitting only one source or sink term per node was mnodified to permit the specification of four sources or sinks per node and the specification of a separate solute concentration for each source via the BCTIME subroutine. If a negative value of IQCP is entered in input data set 17 , data entry via the BCTIME subroutine is invoked and a value for all four sources and sinks must be specified. These data are entered through a new input unit, 56.

\section{List of Input Data for Unit 56}

Datasets one and two must be specified each time the sources or sinks change (i.e., at the beginning of each wet or dry period) 


\section{$\underline{\text { Input Data Set } 1}$}

Specify the date (in decimal years) for the beginning of fluxes specified in dataset 2

\section{VARIABLE}

YEARIN

\section{FORMAT}

D10.5

\section{Input Data Set 2}

Values of flow, QIN $n$ (IQCP), and solute concentration, UIN $n$ (IQCP), for all four fluxes (data for each node on one card for all NN nodes in the model mesh). Pumpage, QIN4, is always a sink so no solute concentration is specified for it.

\section{VARIABLE}

IQCP (node to which data apply)

QIN1 (lateral flow)

UIN1 (lateral flow concentration)

QIN2 (flow from above)

UIN2 (flow from above concentration)

QIN3 (flow from below)

UIN3 (flow from below concentration)

QIN4 (pumpage)

\section{FORMAT}

I3

F12.0

F6.0

F12.0

F6.0

F12.0

F6.0

F9.0 


\section{Changes to SUTRA code}

\section{MAIN PROGRAM}

-- Line $A B 15$ is replaced with rep mn 1

COMMON/FUNITS/ $\mathrm{KOO}, \mathrm{KO}, \mathrm{K} 1, \mathrm{~K} 2, \mathrm{~K} 3, \mathrm{K4}, \mathrm{K} 5, \mathrm{~K} 6$ rep $\mathrm{mn} 1$

-- Line ins mnl is inserted between 1 ines A920 and A930

LOGICAL STEADY

ins $\min 1$

-- Line $\mathrm{A} 1352$ is replaced with rep $\mathrm{mn} 2$

$\mathrm{xO}=99$

rep $\min 2$

-- Lines ins mn2-5 are inserted between lines A1355 and A1356

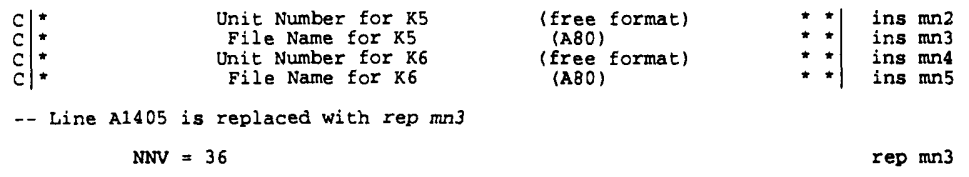

-- Line $\mathrm{A} 3270$ is replaced with rep $\mathrm{mn} 4$

C NOTE: THE LAST POINTER IN THE ABOVE LIST, CURRENTLY, $\operatorname{KRV}(J=56)$, reP mI4

-- Line $A 3300$ is replaced with rep $\operatorname{mn} 5$

C PRESENTLY, SPACE IS ALLOCATED FOR (55) VECTORS. TEP mI5

-- Lines A3270-A3635 are replaced with rep mn6-9 $\begin{array}{lll}\text { * } \quad \operatorname{RV}(\operatorname{KRV}(46)), \operatorname{RV}(\operatorname{KRV}(47)), \operatorname{RV}(\operatorname{KRV}(48)), \operatorname{RV}(\operatorname{KRV}(49)), \operatorname{RV}(\operatorname{KRV}(50)), & \text { rep mn6 } \\ \text { i } \quad \operatorname{RV}(\operatorname{KRV}(5))), \operatorname{RV}(\operatorname{KRV}(52)), \operatorname{RV}(\operatorname{KRV}(53)), \operatorname{RV}(\operatorname{KRV}(54)), \operatorname{RV}(\operatorname{KRV}(55)), & \text { rep mn7 }\end{array}$ IMV (KIMVI), IMV (KIMV2) IMV (KIMV3) IMV (KIMVA). IMV (KIMV5) , rep mn IMV (KIMV6), IMV (KIMV7), IMV (KIMVB), IMV (KIMV9), IMV (KIMV10),

4 IMV (KIMVII);

SUBROUTINE SUTRA

-- Lines B120-B160. are replaced with rep sul-5

3 OIN, QIN1, QIN2, QIN3, UIN, UIN1, UIN2, UIN3, QUIN, PVEC, UVEC, RCIT, rep su1

RCITM1, CC, XX, YY, ALMAX, ALMIN, ATMAX, ATMIN, VMAG, VANG, PERMXX, rep su2

5 PERMXY, PERMYX, PERMYY, PANGLE, PBC, UBC, QPLITR, POBS, UOBS, OBSTIM, rep su

$\begin{array}{lll}6 & \text { GXSI, GETA, IN, IPINCH, IQSOP, IQSOU, IPBC, IUBC, INDEX, IOBS, ITOBS, rep su4 } \\ 7 & \text { NREG, LREG) } & \text { rep su5 }\end{array}$

- Line $B 185$ is replaced with rep su6

COMMON/FUNITS/ KOO, KO, K1, K2, K3, K4, K5, K6 rep su6

-- Line 8310 is replaced with rep su7-8

DIMENSION OIN(NN), OINI (NN), OIN2 (NN), QIN3 (NN), UIN(NN), UINI (NN), $\quad$ rep su7

-- Insert line ins sul between lines $B 440$ and $B 450$

LOGICAL READLT, STEADY/.FALSE. $/$

ins sul

-- Line B510 is replaced with rep sug

1 PERMYX, PERMYY, PANGLE, SOP, NREG, LREG, READLT) rep su9

--Insert lines in su2-4 between lines $B 580$ and $B 590$

CALL ZERO (OIN1, NN, 0.0DO)

CALL ZERO (OIN2, NN, O.ODO)

ins sul

--Insert lines insu5-7 between lines 8590 and $\mathrm{B} 600$

CALL ZERO (UIN1, NN, 0.0DO)

CALL ZERO (UIN2, NN, O.ODO)

CALL ZERO (UIN3, NN, O.ODO)

ins su5

ins su6

ins su7

--Replace line B620 with lines rep su10-11

1 CALL SOURCE (OIN, OIN1, OIN2, QIN3, UIN, UIN1, UIN2, UIN3, IQSOP, QUIN, IEP SU1O

--Insert line ins su8 between lines B1040 and B1050

STEADY $=$.TRUE

ins su8

--Replace lines B1330-B1370 with lines rep sul2-30

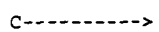

C DETERMINE THE SIZE OF THE NEXT TIME STEP EITHER BY rep sUl 2

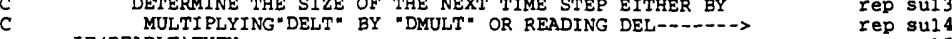
IF (READLT) THEN

C

C DECRIPTION OF DATA SET 6 : TEMPORAL CONTROL AND SOLUTION

C

rep sult

rep sul8

rep sul 9

rep su20 ELSE

COLTIPLY TIME STEP SIZE BY "DMULT" EACH ITCYC TIME STEPS

rep su22

rep su23

$\begin{array}{lll}\text { C MULTIPLY TIME STEP SIZE BY "DMULT* EACH ITCYC TIME STEPS } & \text { rep su24 } \\ \text { C } & \text { AND CHECK AGAINST MAXIMUM ALLOWABLE STEP SIZE "DTMAX" } & \text { rep su2 } 25\end{array}$ 


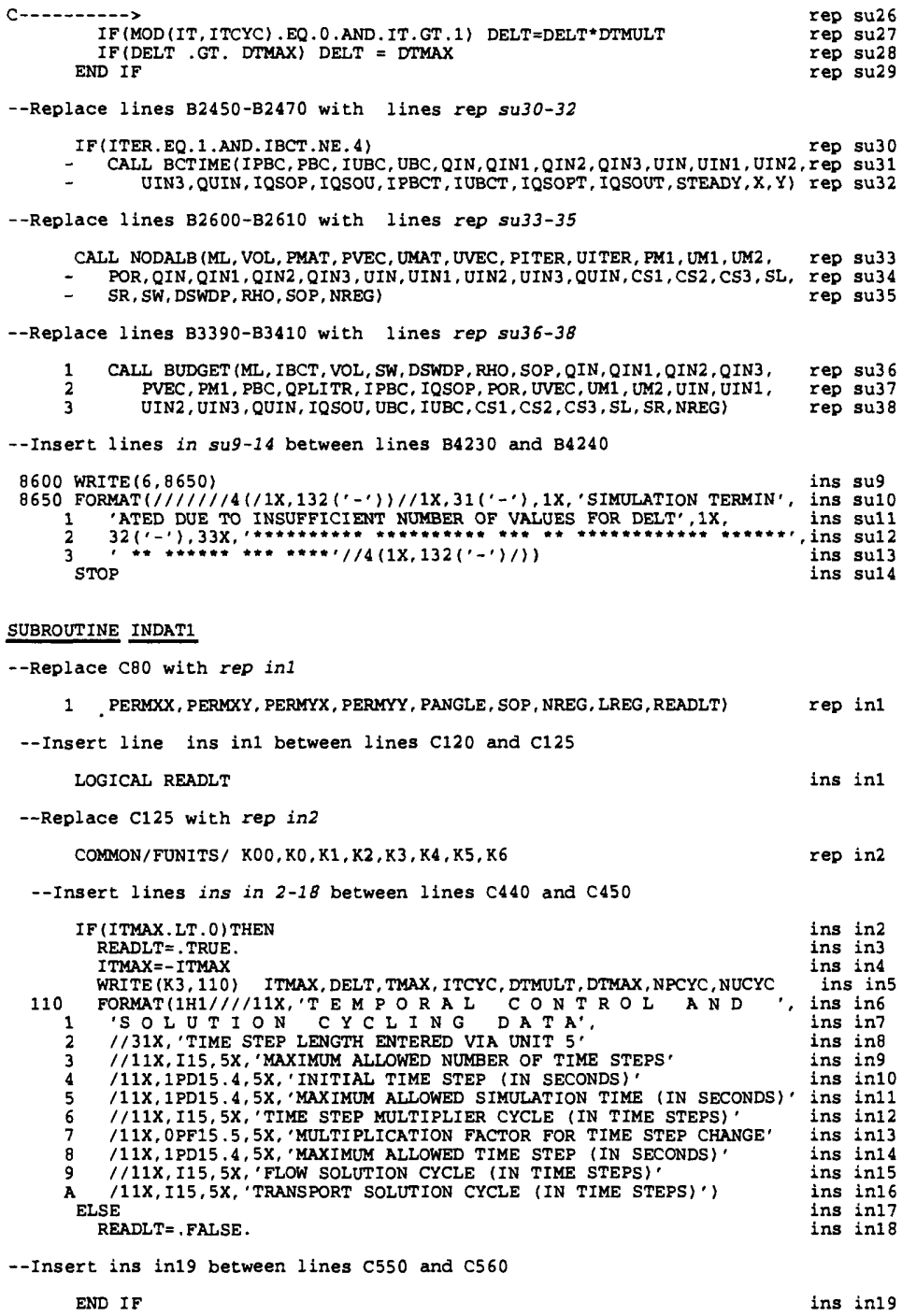

SUBROUTINE PLOT

--Replace D96 with rep pl 1

COMMON/FUNITS/ KOO, KO, K1, K2, K3, K4, K5, K6

rep pll

SUBROUTINE SOURCE

--Replace E70 with rep sr1-2

SUBROUTINE SOURCE (QIN, OIN1, QIN2, QIN3, UIN, UIN1, UIN2, UIN3, IQSOP, reP SY1

--Replace E85 with rep sr 3

COMMON/FUNITS/ KOO, KO, K1, K2, K3, K4, K5, K6 rep sr3

--Replace E130 with rep $\mathrm{s} \times 4-5$

DIMENSION QIN (NN), OIN1, OIN2, OIN3, UIN(NN), UIN1, UIN2, UIN3, rep sr4 IQSOP (NSOP), QUIN (NN), IQSOU (NSOU)

SUBROUTINE BOUND

--Replace F85 with rep bn 1

COMON/FUNITS/ KOO, KO, K1, K2, K3, K4, K5, K6 rep bn1

SUBROUTINE OBSERV

--Replace G125 with rep ob 1

COMMON/FUNITS/ KOO,KO,K1,K2,K3,K4,K5, K6 rep ob1 SUBROUTINE CONNEC 
--Replace H85 with rep cn 1

COMMON/FUNITS/ K00, K0, K1 , K2, K3, K4, K5, K6

rep $\mathrm{cn} 1$

SUBROUTINE BANWID

--Replace I75 with rep ba 1

COMMON/FUNITS/ KOO, KO, K1, K2, K3, K4, K5, k6

rep bal

SUBROUTINE NCHECK

--Replace J85 with rep nC 1

COMMON/FUNITS/ KOO, KO, K1, K2, K3, K4, K5, K6

rep nc1

SUBROUTINE INDAT2

--Replace k105 with rep id 1

COMMON/FUNITS/ KOO, KO, K1, K2, K3, K4, K5, K6

rep idl

\section{SUBROUTINE PRISOL}

--Replace L95 with rep pr 1

COMON/FUNITS/ KOO, K0, K1, K2, K3, K4, K5, K6

rep pr1

\section{SUBROUTINE ELEMEN}

--Replace P145 with rep el 1

COMMON/FUNITS/ KOO, KO, K1, K2, K3, K4, K5, K6

rep e11

\section{SUBROUTINE NODALB}

--Replace T100 and T110 rep nol-3

SUBROUTINE NODALB (ML, VOL, PMAT, PVEC, UMAT, UVEC, PITER, UITER, PM1, UM1, rep nO1

1 UM2, POR, QIN, QIN1, QIN2, QIN3, UIN, UIN1, UIN2, UIN3, QUIN, CS1, CS2, CS3, rep nO2

--Replace T230 - T250 rep no4-7

DIMENSION PITER (NN), UITER (NN), PM1 (NN), UM1 (NN), UM2 (NN), POR (NN), rep nO4

1 QIN (NN), QIN1 (NN), QIN2 (NN), QIN3 (NN), UIN (NN), UIN1 (NN), UIN2 (NN), rep no

$\begin{array}{ll}2 & \operatorname{UIN} 3(\mathrm{NN}), \mathrm{QUIN}(\mathrm{NN}), \mathrm{CS} 1(\mathrm{NN}), \mathrm{CS} 2(\mathrm{NN}), \operatorname{CS} 3(\mathrm{NN}), \mathrm{SL}(\mathrm{NN}), \mathrm{SR}(\mathrm{NN}), \mathrm{SW}(\mathrm{NN}), \text { rep no6 } \\ 3 & \text { RHO (NN), DSWDP(NN), SOP (NN), NREG (NN) no7 }\end{array}$

--Replace T590 rep no8-9

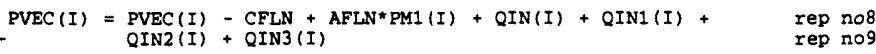

--Replace T770 rep no10-37

$\operatorname{IF}(\mathrm{OIN}(I), G T .0 .0) \mathrm{THEN}$

$Q U L=-C W^{*} Q I N(I)$

QUR $=-$ QUL UIN (I)

QLSE

QUL $=0.0$

(T) IF

IF (OIN1 (I) . GT.0.0) THEN

QUL $1=-C W^{*} \mathrm{OIN} 1(I)$

QUR $1=-$ QULI*UIN 1 (I)

ELSE

OUL $1=0.0$

END IF

IF (QIN2 (I) . GT . 0.0) THEN

(n)

QUL2 $=-C W^{*}$ QIN 2 (I)

ELSE

QUL2 $=0.0$

QUR $2=0.0$

END IF

(OIN3 (I) .GT. 0.01 THEN

QUL $3=-C W^{*}$ QIN 3 (I)

ELSE

QUL $3=0$

QUR3 $=0.0$

END IF

rep nolo

rep noll

rep nol2

rep nol

rep nol

rep nol

rep nol

rep no18

rep nolg

rep no20

rep no21

rep no22

rep no23

rep no24

rep no26

rep no27

rep no28

rep no29

rep no30

rep no3

rep no3

rep no33

rep no34

rep no36

rep no37

--Replace T820 rep no38-41

$370 \operatorname{UMAT}(I, N B H A L F)=\operatorname{UMAT}(I, N B H A L F)+$ ATRN - GTRN - GSLTRN - QUL - rep nO38

- QUL1 - QUL 2 - QUL3 3 - GTRN - OUT

380 UVEC $(I)=\operatorname{UVEC}(I)+$ ATRN $^{*} U M 1(I)+$ ETRN + GSRTRN + QUR + QUR1 + rep no40 QUR2 + QUR3 + QUIN (I)

rep no4

\section{SUBROUTINE BUDGET}

--Replace $\times 70$ - X90 with rep bu 1-3

SUBROUTINE BUDGET (ML, IBCT, VOL, SW, DSWDP, RHO, SOP, QIN, QIN1, OIN2, QIN3, reP bu1

1 PVEC, PM1, PBC, QPLITR, IPBC, IQSOP, POR, UVEC, UM1, UM2, UIN, UIN1, UIN2, rep bu2

--Replace X115 with rep bu4

COMMON/FUNITS/ KOO KO K1, K2, K3, K4, K5, K6

rep bu 4

--Replace X220 with rep bu 5-6 
DIMENSION QIN (NN), QIN1 (NN), QIN2 (NN), QIN3 (NN), UIN (NN), UIN1 (NN), Tep bu5 UIN2 (NN), UIN3 (NN), IOSOP (NSOP), QUIN (NN), IQSOU (NSOU)

--Replace X560 with rep bu 7

$Q I N T O T=Q I N T O T+Q I N(I)+Q I N 1(I)+Q I N 2(I)+Q I N 3(I) \quad$ rep bu7

--Replace $\times 860$ - X900 with rep bu 1-3

IF(INEGCT.EQ.1) WRITE $(K 3,350)(J, J=1,4)$

促

(MASS/SECOND).', rep bug

T37,4(

WRITE (K3,' (22X, I5, 10X, 4D15.7)', -I, QIN (-I), QIN1 (-I), QIN2(-I), rep bu12

450 FORMAT $(22 \mathrm{X}, 15,10 \mathrm{X}, 1 \mathrm{PD} 15,7)$

--Replace X1270 - X1310 with rep bu $15-35$

IF (OIN (I) , GE. 0.0) THEN

QIE (QIN QIUTOT $=Q I U T O T+C W * Q I N(I) * U I N(I)$

END IF

IF (OIN 1 (I). GE. 0.0)THEN

QIUTOT $=$ QIUTOT +CW*UVEC (I) *QIN1 (I)

ELSE

QIUTOT $=$ QIUTOT $+C W^{*}$ QIN1 (I) *UIN1 (I)

aND IF

IF (QIN2 (I) . GE. 0.0) THEN

QIUTOT $=$ QIUTOT +CW*UVEC (I) *QIN2 (I)

ELSE

QIUTOT=QIUTOT+CW*QIN2 (I) *UIN2 (I)

END IF

(OIN 3 (I) GE 0.0$)$ THEN

JIUTOT=QIUTOT+CW*UVEC (I) *QIN3 (I)

ELSE

QIUTO

1300 CONTINUE

rep bu13

--Replace X1810 - X1840 with rep bu 15-35

1649 WRITE $(K 3,1650)(\mathrm{J}, \mathrm{J}=1,4)$

1649 WRITE $(K 3,1650)(\mathrm{J}, \mathrm{J}=1,4)$
1650 FORMAT $(/ / / 22 \mathrm{X}$, 'SOLUTE SOURCES OR SINKS AT FLUID SOURCES AND,$\quad$ rep bu36

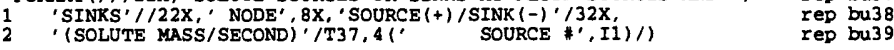

--Replace X1920 - X1960 with rep bu 15-35

IF (QIN (I) . GE. 0.0) THEN

$\mathrm{QU}=\mathrm{QIN}(\mathrm{I}) * C \mathrm{~W}^{*} \mathrm{UVEC}(\mathrm{I})$

BLSE

$Q U=Q I N(I) * C W * U I N(I)$

GND IF

IF (RIN1 (I) . GE . 0 0) THEN

$Q U 1=Q I N 1$ (I) ${ }^{*} C^{\star}{ }^{*} U$ VEC (I)

QUI $=Q I N 1(I){ }^{*} W^{\star} U I N 1$ (I)

QND IF

IF (QIN2 (I) . GE. 0.0) THEN

$Q U 2=Q I N 2(I) * C^{*} U V E C(I)$

QU2 $=$ QIN2 $(I) * C W * U I N 2(I)$

END IF

$I F(Q I N(I)$. GE. 0.0) THEN

$Q U 3=Q I N 3(I) * C W^{*} U V E C(I)$

ELSE

$Q U 3=Q I N 3(I) * C W * U I N 3(I)$

1800 WRITE $(K 3, '(22 X, I 5,10 X, 4 D 15.7)$ ') I, QU, QU1, QU2 , QU3

rep bu15

rep bul16

rep bu18

rep bu19

rep bu20

rep bu22

rep bu23

rep bu25

rep bu26

rep bu27

rep bu29

rep bu30

rep bu31

rep bu32

rep bu33

rep bu35

rep bu40

rep bu41

rep bu42

rep bu43

rep bu4 5

rep bu4 6

rep bu4 7

rep bu48

rep bu4 9

rep bu5

rep bu52

rep bu53

rep bu54

rep bu55

rep bu56

rep bu58

rep bu59

rep bu60

SUBROUTINE STORE

--Replace Y85 with rep st 1

COMMON/FUNITS/ K0O, K0, K1, K2, K3, K4, K5, K6

rep st 1

SUBROUTINE FOPEN

--Replace $\mathrm{z} 120$ with rep fol

COMMON/FUNITS/ $\mathrm{KOO}, \mathrm{KO}, \mathrm{K} 1, \mathrm{~K} 2, \mathrm{~K} 3, \mathrm{~K} 4, \mathrm{~K} 5, \mathrm{~K} 6$

rep fol

--Insert lines ins fol-2 between lines 2580 and $z 590$

$\mathrm{K} 5=\mathrm{IUNIT}(5)$

ins fol

SUBROUTINE BCTIME

--Replace entire subroutine with the following

C SUBROUTINE $\quad$ B $C$ T $I$ M E SUTRA - VERSION 0690-2D

\#\#* PURPOSE

C ** USER-PROGRAMMED SUBROUTINE WHICH ALLOWS THE USER TO SPECIFY:

C *** (1) TIME-DEPENDENT SPECIFIED PRESSURES AND TIME -DEPENDENT
$C * * *$ CONCENTRATIONS OR TEMPERATURES OF INFLOWS AT THESE POINTS

C ${ }^{* * *}$ (2) TONCENTRATIONS OR TEMPERATURES OF INFLOWS AT THESE POIN

$\begin{array}{ll}c * * * & (2) \text { TIME-DEPENDENT SPECIFIED CONCENTRATIONS OR TEMP } \\ C * * * & \text { (3) TIME-DEPENDENT FLUID SOURCES AND CONCENTRATIONS }\end{array}$

*** OR TEMPERATURES OF INFLOWS AT THESE POINTS

(4) OR TEMPERATURES OF INFLOWS AT THESE POINTS

c dbn SUBROUTINE BCTIME (IPBC, PBC, IUBC, UBC, QIN, UIN, QUIN, IQSOP, IQSOU,

c dbn 1 IPBCT, IUBCT, IQSOPT, IQSOUT, $X, Y)$

SUBROUTINE BCTIME (IPBC, PBC, IUBC UBC, OIN, OIN1, OIN2, OIN3, UIN, UIN1

1 UIN2, UIN3, QUIN, IQSOP, IQSOU, I PBCT, IUBCT, IQSOPT, IQSOUT, STEADY, 
IMPLICIT DOUBLE PRECISION (A-H,O-Z)

COMMON/FUNITS/ $\mathrm{XOO}, \mathrm{KO}, \mathrm{K} 1, \mathrm{K2}, \mathrm{K3}, \mathrm{K4}, \mathrm{K5}, \mathrm{X6}$

COMMON/DIMS/ NN, NE, NIN, NBI, NB, NBHALF, NPINCH, NPBC, NUBC,

1 NSOP, NSOU, NBCN

COMMON/TIME/ DELT, TSEC, TMIN, THOUR, TDAY, TWEEK, TMONTH, TYEAR,

TMAX, DELTP, DELTU, DLTPM1, DLTUM1, IT, ITMAX

c dbn DIMENSION IPBC (NBCN), PBC (NBCN), IUBC (NBCN), UBC (NBCN)

QIN (NN), UIN (NN), QUIN (NN), IQSOP (NSOP), IQSOU (NSOU), X (NN), Y (NN)

DIMENSION I PBC (NBCN), PBC (NBCN), IUBC (NBCN), UBC (NBCN)

(NN), UIN 1 (NN), UIN2 (NN) LOGICAL GOBACK $/$. FALSE. $\%$, STEADY

DATA SECNDA $/ 86400.0 \%$

C.... DEFINITION OF REQUIRED VARIABLES

C ' ${ }^{\circ}=$ EXACT NUMBER OF NODES IN MESH

NPBC = EXACT NUMBER OF SPECIFIED PRESSURE NODES

NUBC = EXACT NUMBER OF SPECIFIED CONCENTRATION

OR TEMPERATURE NODES

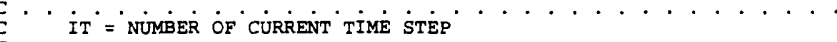

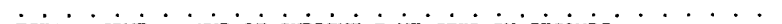

TSEC = TIME AT END OF CURRENT TIME STEP IN SECONDS

TMIN = TIME AT END OF CURRENT TIME STEP IN MINUTES

THOUR = TIME AT END OF CURRENT TINE STEP IN HOURS

TDAY = TIME AT END OR CURR

TMONTH = TIME AT DND OF CURRETT TIME STEP IN MONTHS

TYEAR = TIME AT END OF CURRENT TIME STEP IN YEARS

- PBCiIP) = SPECIFIED PRESSURE VALUE AT IP(TH) SPECIFIED

UBC (IP) = SPECIFIED CONCENTRATION OR TEMPERATURE VALUE OF ANY

IPBC (IP) = ACTUAL NODE NUMBER OF IP(TH) SPECIFIED PRESSURE NODE (WHEN NODE NUMBER I $=$ IPBC (IP) IS NEGATIVE $(I<0)$,

VALUES MUST BE SPECIFIED FOR PBC AND UBC.)

- UBC (IUP) ${ }^{\circ}$ SPECIFIED CONCENTRATION OR TEMPERATURE VALUE AT IU(TH) SPECIFIED CONCENTRATION OR TEMPERATURE NODE

(WHERE IUP $=$ IU + NPBC

IUBC (IUP) = ACTUAL NODE NUMBER OF IU(TH) SPECIFIED CONCENTRATION OR TEMPERATURE NODE (WHERE IUP=IU+NPBC)

(WHEN NODE NUMBER I=IUBC (IU) IS NEGATIVE $(I<0)$,

IQSOP (IQP) " NODE NUMBER OF IQP (TH) FLUID SOURCE NODE. (WHEN NODE NUMBER I=IQSOP (IQP) IS NEGATIVE $(I<0)$, VALUES MUST BE SPECIFIED FOR QIN AND UIN.?

QIN $(-I)=$ SPECIFIED FLUID SOURCE VALUE AT NODE (-I)

UIN $(-I)=$ SPECIFIED CONCENTRATION OR TBMPERATURE VALUE OF ANY INFLOW OCCURRING AT FLUID SOURCE NODE $(-I)$

IQSOU (IQU) $=$ NODE NUMBER OF IQU (TH) ENERGY OR

SOLUTE MASS SOURCE NODE

(WHEN NODE NUMBER I=IQSOU (IQU) IS NEGATIVE $(I<0)$

QUIN $(-I)=\begin{gathered}\text { A VALUE MUST BE SPECIFIED FOR QUIN.) } \\ \text { SPECIFIED ENERGY OR SOLUTE MASS SOURCE VALUE }\end{gathered}$ NODE (-I)

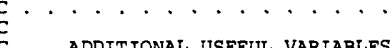

" "FUNITS" ARE UNIT NUMBERS FOR INPUT AND OUTPUT FILES

AS ASSIGNED IN THE INPUT FILE, "SUTRA.FIL

$X$ (I) AND $Y(I)$ ARE THE $X$ - AND $Y$-COORDINATES OF NODE I

GRAVX AND GRAVY ARE THE $X$ - AND $Y$-COMPONENTS OF THE GRAVITY VECTOR

C

C..... NSOPI IS ACTUAL NUMBER OF FLUID SOURCE NODES

C.... NSOUI IS ACTUAL NUMBER OF ENERGY OR SOLUTE MASS SOURCE NODES

TISNOW $=1941.0+$ TYEAR

WRITE (K6,' (3HIT : , I4 , 5X, 27Hend of dataset... returning)') IT RETURN

END IF

READ (K5, (D10.5)', END $=30)$ YEARIN

WRITE (K6, ' (3HIT: , I4 , 5X, 7HTISNOW: , F10 . 4, 5X, 7HYEARIN : , F10.4)',IT,

TISNOW, YEARIN

IF (STEADY.OR. YEARIN-TISNOW. LT .0.001) THEN

WRITE (K6,' (29HReading source/sink data for, F9.4) $)$ YEARIN

READ (K5,' (I3, F12.2, F6.0,F12.2,F6.0,F12,2,F6.0,F9.1)') (I, OIN(I)

DO $10 \mathrm{~J}=1$, NN

$\operatorname{QIN}(\mathrm{J})=\operatorname{QIN}(\mathrm{J}) / \mathrm{SECNDA}$

QIN1 (J) $=$ QINI (J) /SECND

$10 \operatorname{OIN} 3(\mathrm{~J})=\operatorname{QIN} 3(\mathrm{~J}) / \operatorname{SECNDA}$

IF (IPBCT.LT. O) THEN

$20 \operatorname{IF}(I P B C$ (IP).LT. O) READ (K5, ' (I3,F12.2,F6.0) ' ) J, PBC (J), UBC (J)

IF IF

IF

BACXSPACE (UNIT $=\mathrm{X} 5$ )

$$
\begin{aligned}
& \text { WRITE } \\
& \text { END IF }
\end{aligned}
$$

30 RETURN GOBACK = TRUE.

RETURN

END 